\title{
The economics of unpaid work
}

Citation for published version (APA):

Bruyn-Hundt, M. (1996). The economics of unpaid work. [Doctoral Thesis, Maastricht University]. Thesis Publishers. https://doi.org/10.26481/dis.19960626mb

Document status and date:

Published: 01/01/1996

DOI:

10.26481/dis.19960626mb

Document Version:

Publisher's PDF, also known as Version of record

\section{Please check the document version of this publication:}

- A submitted manuscript is the version of the article upon submission and before peer-review. There can be important differences between the submitted version and the official published version of record.

People interested in the research are advised to contact the author for the final version of the publication, or visit the DOI to the publisher's website.

- The final author version and the galley proof are versions of the publication after peer review.

- The final published version features the final layout of the paper including the volume, issue and page numbers.

Link to publication

\footnotetext{
General rights rights.

- You may freely distribute the URL identifying the publication in the public portal. please follow below link for the End User Agreement:

www.umlib.nl/taverne-license

Take down policy

If you believe that this document breaches copyright please contact us at:

repository@maastrichtuniversity.nl

providing details and we will investigate your claim.
}

Copyright and moral rights for the publications made accessible in the public portal are retained by the authors and/or other copyright owners and it is a condition of accessing publications that users recognise and abide by the legal requirements associated with these

- Users may download and print one copy of any publication from the public portal for the purpose of private study or research.

- You may not further distribute the material or use it for any profit-making activity or commercial gain

If the publication is distributed under the terms of Article $25 \mathrm{fa}$ of the Dutch Copyright Act, indicated by the "Taverne" license above, 
THE ECONOMICS OF UNPAID WORK 


\section{THE ECONOMICS \\ OF \\ UNPAID WORK}

\section{PROEFSCHRIFT}

ter verkrijging van de graad van doctor

aan de Rijksuniversiteit Limburg te Maastricht,

op gezag van de Rector Magnificus, Prof. mr. M.J. Cohen, volgens het besluit van het College van Dekanen,

in het openbaar te verdedigen

op woensdag 26 juni 1996 om 16.00 uur

door

Margaretha Bruyn-Hundt 
Promotoren: $\quad$ Prof. dr. J. Muysken

Prof. dr. W. Albeda

Beoordelingscommissie: Prof. dr. C. de Neubourg, (voorzitter)

Prof. dr. J.G. Backhaus

Prof. dr. J. van Doorne-Huiskes

(Erasmus Universiteit, Rotterdam)

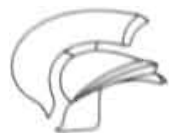

Thesis Publishers, Amsterdam, 1996

ISBN $90-5170-379-1$

NUGI $662 / 665$

All rights reserved. No part: of this book may be reproduced or transmixted in any form or by any means, electronical or mechanical, including photocopying, recording, or by añy information storage and retrieval system without written permission from the publisher, except for the inclusion of brief quotations. in a review. 
Aan mijn moeder, die doorzette toen ik opgaf

Aan mijn kinderen, die meer geduld met mij hadden dan $\mathrm{ik}$ met hen

Aan mijn levenskameraad, die mij steeds met raad en daad terzijde stond 



\section{PREFACE}

In this preface I will explain why I, at my age, have written a doctoral thesis and why I have chosen as a subject "Unpaid. work". Women of my generation (I was born in 1931) withdrew as a matter of course from the labour market when they got married. Married women were supposed to look after household and children. Until 1957 Dutch law commanded the dismissal of female civil servants when they got married. Household work was the main occupation for women of my generation.

My parents stimulated me to go to university and study economics in case 1 would not marry or would become a widow or a divorcée. They thought that having a good education would enable me to earn a living of my own if necessary. Only $3 \%$ of my fellow students in economics were female. A.t that time many people thought that the only reason for a woman to go to university was to catch a well-earning husband.

On our wedding day my parents gave my husband and I a Bible in which they wrote the wish that I would become a good housewife. This was no problem for me as I considered and still consider housekeeping an agreable activity provided it can be combined with other activities. During my study of economics the idea of Mrs. Christine Frederick published in a book in 1927 to apply the principles of scientific management to the household, attracted my special attention. I decided to use my knowledge of economics in this field. This was not as easy as I thought. When I had my children it turned out that the only way I could use my knowledge of economics was to work as a part-time economics teacher at a secundary school. So I taught my 16 to 19 year old pupils the meaning of production, consumption etc. Household labour or child care were not mentioned in any of the books available for secundary schools. It was considered neither production nor consumption by my fellow economists who had written these schoolbooks.

It seemed unjust and it annoyed me very much, that work that I regarded very important for the wellbeing of the family and the society got so little attention in economic science and economic policy. In the seventies, in order to attract attention to the phenomenon of unpaid work, I published several scientific articles in which I calculated the value of unpaid household labour and I proposed to give housewives a wage. Much public discussion followed and eventually I reversed my opinion on a wage for housewives, because it does not give women equal positions in society.

It is a paradox, unpaid work is on the one hand indispensable for the wellbeing of the next generation, the family and the society and on the other hand it is a hindrance to improve women's economic position. It is a dilemma that women have to diminish the time they spend on unpaid activities, which many of them like doing, in order to do paid work which gives economic independence and 
also satisfaction. It is not unpaid work itself, but it is the unequal division of unpaid and paid work between men and women, mothers and fathers, which leads to unequal economic positions. If unpaid work would be divided more equally between the sexes and if society would be willing to grant people some facilities in the period they are raising young children, this problem could be solved. I hope this book will contribute to a more equal division of paid and unpaid work and to more equal positions of men and women.

In 1975 I became an Assistant Professor of Economics at the Faculty of Economics and Econometrics of the University of Amsterdam and in 1981 I became a member of the Government Advisory Commission "Emancipatieraad" (the Commission for Equal Rights and Opportunities for Women). I wrote three books and numerous articles on women's positions in paid and unpaid labour. Through the years I received several distinctions for my work. In completion of my scientific work this doctoral thesis has been written (I did not have the opportunity to do this earlier in life) on a subject which already attracted my attention when I was a young woman: the economic value of unpaid work.

At Christmas 1993 I received a Christmas card from Wil Albeda and he asked me if I had ever considered to obtain a doctorate. In April 1994 we met again and I told him that I had indeed considered this. Immediately he invited me to write my doctoral thesis under his conduct. In December 1994 I was introduced to Joan Muysken who was also willing to act as a promoter. I thank them both for the inspiring talks we had and the suggestions and advice they gave me. I am grateful for the discussions and criticism on earlier versions of this book by members of the "Emancipatieleerstoel" (Chair in Emancipation) of the Faculty of Economics, University of Amsterdam, as well as by members of the interdisciplinary group of the project Time Allocation, financed by "NWO - Nederlandse Organisatie voor Wetenschappelijk Onderzoek" (Netherlands Organization for Scientific Research). I enjoyed the meetings of the Feminist Economics Network, where I was allowed to present one of the chapters of this book. I am thankful for comments on several chapters of this book by Haroon Akram-Lodhi, Brugt Kazenier, Marry Niphuis-Nell, Joop Odink, Janneke Plantenga and Jacques Siegers. Many thanks to Els Berger, who corrected my English in the first chapters and to Comélie Janus-Derks who also corrected my English and made the manuscript ready for printing. My husband I have to thank for his contribution in arranging part of the data with the SPSS-programme and the calculations of the Theil coefficients. I was very happy to have been able to write the greater part of this doctoral thesis in my beloved Swiss home in the Valais, with one eye on the beautiful mountains and one eye on my computer.

Haute-Nendaz, March 1996 


\section{THE ECONOMICS OF UNPAID WORK}

\section{TABLE OF CONTENTS}

1 INTRODUCTION

PART I: UNPAID WORK IN THE NETHERLANDS

2 UNPAID WORK IN ECONOMIC THEORY 21

2.1 Introduction 21

2.2 Contents and scope of economic science 21

2.3 Production or consumption 24

2.4 The allocation of time: a micro-economic model 28

2.5 The price of unpaid work in economic theory 36

2.6 Summary and conclusion 39

3 METHODS TO VALUE UNPAID WORK 41

3.1 Introduction 41

3.2 The input method 41

3.3 The output method 45

3.4 Overview of calculations of the value of unpaid work 49

3.5 Summary and conclusion 51

4. UNPAID WORK IN THE NETHERLANDS 1975-1990 53

4.1 Introduction 53

4.2 Time use research in the Netherlands: an overview

4.3 The data for this study 55

4.4 Types of unpaid work 56

4.5 Empirical estimations of the value of unpaid work

4.6 Total workload per age group and between sexes 63

4.7 The division of paid and unpaid work between sexes 66

4.8 Unpaid work per household type 69

$\begin{array}{ll}4.9 & \text { Summary and conclusion }\end{array}$

5 THE SYSTEM OF NATIONAL ACCOUNTS 73

5.1 Introduction 73

5.2 What is measured by the System of National Accounts? 73

5.3 The debate about imputing the value of household services $\quad 74$ in National Accounts

5.4 Unpaid work in the Dutch National Accounts 80

5.5 Other economic phenomena and unpaid work 89

$\begin{array}{ll}\text { 5.5.1 Welfare and economic growth } & 89\end{array}$

5.5.2 Economic fluctuations and unpaid work 92

5.5.3 Employment and unpaid labour 93

5.5.4 Unemployment and unpaid labour 96 
5.5.5 Consumption and investments 98

5.5.6 Optimal allocation of production factors. 100

5.5.7 Public finance 102

5.6 Summary and conclusion 103

6 UNPAID WORK IN INCOME DISTRIBUTION 105

6.1 Introduction 105

6.2 What is measured by traditional income statistics? 105

$\begin{array}{lll}6.3 & \text { Measuring income inequality } & 107\end{array}$

6.4 The combination of paid and unpaid work in income

6.5 Unpaid work in the 1985 and 1990 Dutch income distribution 111

6.5.1 Data and method 111

6.5.2 Results 113

6.5.2.1 Income per household type 113

6.5.2.2 Income per household type and age group 119

6.5.2.3 Income inequality 121

$\begin{array}{lll}6.6 & \text { Summary and conclusion } & 123\end{array}$

7 UNPAID WORK IN ECONOMIC MODELS 125

$\begin{array}{lll}7.1 & \text { Introduction } & 125\end{array}$

7.2 Structure and scope of macroeconomic models 125

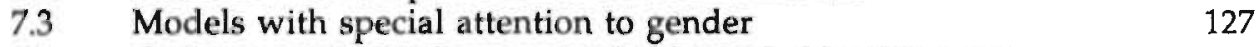

7.4 Criticism on MIMIC: an extended household sector model

7.5 The relation between paid and unpaid work 133

7.6. The implementation of unpaid work in macro models $\quad 140$

$\begin{array}{lll}7.7 & \text { Summary and conclusion } & 144\end{array}$

PART II: UNPAID WORK AND ECONOMIC INDEPENDENCE 145

8 ECONOMIC INDEPENDENCE: MOTIVATION AND MEASUREMENT 147

$\begin{array}{lll}8.1 & \text { Introduction } & 147\end{array}$

$\begin{array}{ll}\text { 8.2 Definition of economic independence } & 147\end{array}$

8.3 Economic independence and sex 148

8.4 Microeconomic measurement of economic independence 152

8.5 Macroeconomic measurement of economic independence 154

8.6 Economic independence as a target of economic policy 157

$\begin{array}{lll}8.7 & \text { Resolutions of women's international conferences } & 158\end{array}$

8.8 National Accounts and economic independence 159

$\begin{array}{lll}8.9 & \text { Summary and conclusion } & 160\end{array}$

9 ECONOMIC INDEPENDENCE AND UNPAID WORK 161

9.1 Introduction 161

9.2 Welfare-systems in Europe 161

9.3 Wages for the housewife 164 
9.4 Negative Income Tax or a basis income 168

9.5 Unpaid work: a pitfall 170

9.6 Equal rights policy and attitudes in the Netherlands since $1975 \quad 171$

9.7 Policies for an equal sharing of paid and unpaid work. 172

$\begin{array}{lll}9.7 .1 & \text { Family policies } & 173\end{array}$

$\begin{array}{ll}9.7 .2 & \text { Income policies } \\ 9.7 & 177\end{array}$

9.7.3 Labour markt policies 186

$\begin{array}{lll}9.8 & \text { Summary and conclusion } & 191\end{array}$

10 SUMMARY 193

$\begin{array}{ll}\text { BIBLIOGRAPHY } & 197\end{array}$

$\begin{array}{ll}\text { INDEX } & 209\end{array}$

$\begin{array}{ll}\text { CURRICULUM VITAE } & 215\end{array}$

$\begin{array}{ll}\text { SAMENVATTING } & 217\end{array}$ 



\section{INTRODUCTION}

"It is characteristic of the age in which we live to think too much in terms of economics, to see things too predominantly in their economic aspect... There is no more important prerequisite to clear thinking in regards to economics itself than its recognition of its limited place among human interests at large" (Frank H. Knight 1933 (1))

Every recent economics textbook discusses simultaneously the supply and demand of labour and the way in which labour and wages are determined. Economists often take it for granted that "labour" automatically means "paid" labour. Until the nineteen sixties unpaid labour was largely neglected in economic theory and economic policy. Becker's famous article on the allocation of time (Becker 1965) was the beginning of a new stream of economic thinking: the New Home Economics which stated that the household was a unit of production as well as of consumption. Since that time economic theory has paid increased attention to unpaid labour. It is not surprising to see this growing attention for unpaid labour in economic theory, considering the fact that, worldwide, men as well as women spend a considerable number of hours on unpaid labour.

Table 1.1. illustrates these facts(2). The bulk of time is spent on personal care: sleeping, eating, personal hygiene etc. consume about 41 to $44 \%$ of total time available. Leisure is the second most important time use: 23 to $30 \%$. Paid work is the third important for men. For women unpaid work is the third important time use: they spend more time on unpaid work than on paid work.

The differences in time allocation between countries are greatest regarding the activities market work and housework. In Japan, men have the longest hours of market work: $31 \%$ of all hours per week are spent on market work; men in Sweden have the longest hours of housework: $11 \%$. The differences in time men spend on personal care and leisure are smaller. The total workload of paid and unpaid activities is highest for men in Sweden: they spend 35\% of their time on work.

\footnotetext{
1 as quoted by Marc Nerlove in "Toward a new theory of population and economic growth" in "Economics of the family" (University of Chicago Press 1974 p.527.

2 Juster and Stafford (1991) divided time into work time, in turn subdivided into market work and household work; into personal care (principally sleep and rest); and into a number of leisure activities including education, voluntary work, social entertainment, active (sports etc.) and passive leisure (watching TV etc.) (see Juster and Stafford 1985 p.330-332). Their classification of (unpaid) household work differed from the classification used by the Dutch Social and Cultural Planning Office and by myself in chapter 4. A more detailed analysis and description of the classification of different activities is giver in sections 2.4 and 4.4. In table 1.1. the classification of Juster and Stafford is used in order to compare different countries.
} 
Table 1.1.

Time allocation between countries as a percentage of all hours available per week $(100 \%=168$ hours $)$

\begin{tabular}{|c|c|c|c|c|}
\hline \multirow[b]{2}{*}{ Country } & \multicolumn{4}{|l|}{ Men } \\
\hline & USA & Japan & Sweden & Netherlands \\
\hline & 1981 & 1985 & 1984 & 1985 \\
\hline Paid work & 26 & 31 & 24 & 19 \\
\hline Unpaid work & 8 & 2 & 11 & 8 \\
\hline Personal care & 41 & 43 & 42 & 42.5 \\
\hline Leisure & 25 & 24 & 23 & 30.5 \\
\hline \multirow[t]{4}{*}{ Total time } & 100 & 100 & 100 & 100 \\
\hline & \multicolumn{4}{|c|}{ Women } \\
\hline & USA & Japan & Sweden & Netherlands \\
\hline & 1981 & 1985 & 1984 & 1985 \\
\hline Paid work & 14 & 15 & 14 & 5 \\
\hline Unpaid work & 18 & 18 & 19 & 21 \\
\hline Personal care & 43 & 43 & 44 & 44 \\
\hline Leisure & 25 & 24 & 23 & 30 \\
\hline Total time & 100 & 100 & 100 & 100 \\
\hline
\end{tabular}

Source: Juster and Stafford (1991), Table 1 and Knulst and Van Beek. (Intomart) (1990)(3)

Women in Japan are at the top regarding market work: $15 \%$ of their time is spent on this activity. Women in the Netherlands have the longest unpaid hours: $21 \%$ of their time. The workload of women in Japan and Sweden is highest: $33 \%$ of their time is spent on work. Women in the Netherlands have the lowest workload.

Time men and women spend on housework is considerable compared to time spent on market work. The leading question of part I of this study is how the value of unpaid work can be estimated and how its value can be accounted for in economic phenomena and used in economic policy. The value of unpaid labour will be determined on the basis of hours of unpaid work in time use surveys in the Netherlands in 1975, 1980, 1985 and 1990. One of the consequences of neglecting unpaid labour is that unpaid labour is not at all or scarcely registered in official statistics and not counted and integrated in economic phenomena.

${ }^{3}$ The figures for the USA, Japan and Sweden come from Juster and Stafford 1991, table 1. The figures for the Netherlands corne from the 1985 time use survey of Knulst and Van Beek 1990 appendix C (Intomarit). Juster and Stafford remarked that there were substantial difficulties to put together consistent data, because classifications of time use, the range of ages and the methodology of time use research differ from country to country. For the Netherlands the activities of men and women aged 25-64 were classified (as good as possible) according to Juster and Stafford (1985) p.331. Gardening, care of pets and plants, sewing, knitting and other fancy needlework, small do-it-yourself jobs, were counted as leisure according to Juster and Stafford. 
Another consequence is that women's position in society, especially women's rate of economic independence, differs from men's, because women have a larger share in unpaid work than men. In the 1995 United Nations Human Development Report one can read on page 88: "Extensive research was undertaken on the amount of time women and men spend on market and nonmarket activities. A review of the 31 countries in the sample tells a fairly dramatic story:

- Women work longer hours than men in nearly every country. Of the total burden of work, women carry on average $53 \%$ in developing countries and $51 \%$ in industrial countries.

- Of men's total work time in industrial countries, roughly two-thirds is spent in paid SNA activities and one-third in unpaid non-SNA-activities. For women these shares are reversed. In developing countries, more than three-fourths of men's work is in SNA activities. So, men receive the lion's share of income and recognition for their econornic contribution - while most of women's work remains unpaid, unrecognized and undervalued(4)".

The principal author of the report, Mahbub ul Haq says: "There is an unwitting conspiracy on a global scale to undervalue women's work and contributions to society. In virtually every country of the world, women work longer hours than men, yet share less in the economic reward. If women's work were accurately reflected in national statistics, it would shatter the myth that men are the main breadwinners of the world".

Economists' attention is more focused on paid than on unpaid work. Certain activities and experiences that are historically of greater concern to women than to men have all too frequently been neglected. Economists are "gender blind": they think that their assumptions and methodologies are universal and impartial. Gender blind means that they neglect social differences between men and women. Mainstream economists assume that greed and rationality characterize human behaviour. Becker (following Adam Smith) made an exception by introducing the "altruistic" head of a household. However feminist economists consider Becker's assumption of an "altruistic" head of a household as patriarchal and one-sided, because it ascribed the head's behaviour to his altruism rather than to his power over household resources (Ferber and Nelson 1993). Solow acknowledges that there has been a tendency for male economists to patronize women. He thinks that women, compared to men, are more involved in forms of activities based on solidarity, voluntary work, gift exchange and emphaty. Their experience suggests hypotheses and ideas worth trying out, but he

\footnotetext{
4 In the Intomart time use surveys (see table 4.1. in this book) it is shown that in the period 19751990 women of 12 years and over spent $79-86 \%$ of their time on unpaid work, men $39-44 \%$. In unpaid work activities like painting and papering, repairs in and around the home were taken into account. In paid work all time spent on the job was taken into account, whether it was directly paid or not. For the age groups $25-49$ the differences between men and women are higher: the percentages spent on unpaid work vary between 75 to $80 \%$ of women's working time and 20 to $25 \%$ of men's working time. Similar results are shown in the 1987 Statistics Netherlands time use survey (SN 1989 p.41).
} 
is sceptical of the notion that a move from male dominance would change what he considers the substance of the discipline (Solow, 1993). The question "Why are economists gender blind", remains unanswered.

Part of the answer may be the concepts of contents and scope of economic science in the course of time. In chapter two a short historical analysis is given of the definition of economic science and ideas about production and consumption to answer the question why unpaid work has got so little attention in economic science until the second half of this century. It is argued that unpaid work used to be seen as an unproductive activity and has become a productive one now. It was considered leisure and now it has become work even if no wages are paid. The theory of the New Home Economics which was developed by Mincer, Becker, Gronau and others opened new views on economic phenomena e.g. unpaid work.

There are several ways to "engender" economics. A first method is to disaggregate existing variables by gender. This method does not entail incorporation of unpaid household labour into the analysis. A second method is to introduce economic variables which capture the structure of gender relations, e.g. the degree of gender inequality in labour and credit markets. A third method is to conceptualize the world in two sectors: paid and unpaid work and tracing the feedbacks between the variables in the two systems. A fourth method is to combine two or more of the previous methods (Çagatay, Elson and Grown 1995). The third method is followed in this study.

The question how to determine the volume and value of unpaid labour is deait with in chapter three. In order to obtain a calculation of the value of unpaid work, a measure of the volume of unpaid work multiplied by a price component is needed. Theoretically the best way to determine the value of unpaid labour is to determine the value of the output of the household. Because it is very difficult to measure output, the input of hours of unpaid work has been used in most calculations to calculate the value. Data on the volume of unpaid work can be found in demographic statistics or time use surveys. A measure of the "shadow" price of unpaid work is taken from wages in the market sector.

In chapter four data are presented on the volume and value of unpaid work in the Netherlands in the period 1975-1990, based on time use surveys and three different wage estimates: the legal minimum wages, the wage of a home help, and the average earned wages.

The System of National Accounts was started in the beginning of the nineteenth century. Unpaid labour was left out then and has never been added since, although much attention was paid to this question in lengthy discussions about refinement of the National Accounts. Chapter five discusses why unpaid work is not counted in National Accounts and how National Accounts would look if implemented. Implementation would also change other economic phenomena, e.g. welfare and economic growth, economic fluctuations, employment, 
consumption. The way in which these economic phenomena would change if unpaid were integrated into economic statistics is discussed in this chapter.

Recent research shows that unpaid work diminishes the differences in personal welfare. Personal income distribution in the Netherlands including the value of unpaid work is presented in chapter six.

Chapter seven discusses how unpaid work can be implemented in macroeconomic models. A model of the Dutch Central Planning Bureau has been used to demonstrate how this can be done in practice.

In part II people's position in society is discussed in as far as it depends on and is related to the amount and the quality of paid and unpaid work a person does. Using this as a standard in chapter eight, a micro- and macroeconomic statistical measure for economic independence has been developed.

Women's share in unpaid work is much larger than men's and their share in paid work is much smaller. For that reason women's rate of economic independence, although increasing, is much lower than men's. Several ways and means to improve women's economic independence are analysed in chapter nine. Chapter ten contains a summary and conclusions. 

PART I

UNPAID WORK IN THE NETHERLANDS 



\section{UNPAID WORK IN ECONOMIC THEORY}

"Economic theory is a science with a hole in it: economists cannot quantify, cannot measure the central phenomenon utility" (Jan Pen 1995).

\subsection{Introduction}

Economists' ideas about the contents and scope of economic science and about basic economic phenomena including production and consumption, have changed in the course of time. This may be one of the reasons why so little attention had been paid to unpaid work until the nineteen sixties. Therefore sections 2 and 3 give a short historical analysis. First the ideas of the physiocrats are examined, then the concepts of classical and socialist economists, the Anglo-American school and finally the ideas of the New Home Economics. New ideas about the allocation of time are given in section 4 . Section 5 discusses the wages which can be taken into account for unpaid work. Section 6 contains a summary and conclusion.

\subsection{Contents and scope of economic science}

Mark Blaug (1978 p.4) remarks that "the history of economics is not so much the chronicle of a continuous accumulation of theoretical achievements as the story of exaggerated intellectual revolutions in which truths already known are neglected in favour of new revelations". This statement is enlightening if one regards the different opinions and definitions of economic science. Blaug thinkst that the title of Adam Smith's "Inquiry into the nature and the causes of the wealth of nations" represents very well the ideas on economic science in the nineteenth century. Other important elements in Adam Smith's way of thinking were the distribution of welfare among people and the division of labour. In Smith's view people specialize in certain activities and exchange the products of these activities out of self-interest. "It is not from the benevolence of the butcher, the brewer, or the baker, that we expect our dinner, but from their regard to their own interest" (Smith Penguin reprint 1976 p.119). The only exception Smith made concerning the motivating force of self-interest in men's economic activities is his family. "After himself, the members of his own family, those who usually live in the same house with him, his parents, his children, his brothers and sisters, are naturally the object of his warmest affections" (Smith as quoted by Becker 1981 p.172). And in 1881 Edgeworth wrote that "the first principle of Economics is that every agent is actuated only by self-interest" (Edgeworth as quoted by Sen 1982 p.84).

This concept of self-interest as the omnipotent force underlying economic behaviour is criticized by later economists (Sen 1982, Hirshleifer 1985, Nelson and Ferber 1993). Sen (1982). supposes that Edgeworth thought of exchange equilibria in competitive markets. Sen remarks that: "Admitting behaviour based on 
commitment would have far-reaching consequences on the nature of many economic models". He defines commitment as concern for others which did not affect one's own welfare. Hirshleifer (1985) points out that it was not easy to separate self-interest and non-self-interest. Suppose a person's ends in life include the well-being of others. If so, do their interests become his "self-interest"? Hirshleifer thinks that if one answers this question affirmatively, the concept of self-interest was robbed of any distinguishable content. Feminist criticism on the concept of economic science is that it is supposed that individuals are always free to react to their social and economic environment. Oppression, differences in power and authority, social and religious obligations, laws regulating legal competence, legal measures concerning tax, social security and pensions differ between individuals, social classes, sexes, ethnic groups. They can and do reduce the possibility to choose in such a way that economic models become empty boxes (Nelson 1993; Blank 1993; Williams 1993).

Alfred Marshall (1890) defines economics as follows: "Economics is a study of mankind in the ordinary business of life; it examines that part of individual and social action which is most closely connected with the attainment and with the use of the material requisites of wellbeing. Economic goods are all those things, external to a man, which (1) belong to him and which (2) are directly capable of a money measure, a measure that represents on the one side the efforts and sacrifices by which they have been called into existence and, on the other, the wants which they satisfy" (Marshall eighth edition 1979 p.1 and p.47).

Lionel Robbins (1932) suggests a short definition: "Economics is the science which studies human behaviour as a relationship between ends and scarce means that have alternative uses" (Robbins 1962 p.16).

Paul A. Samuelson (1955) collected a few definitions:

- "Economics, or political economy, is the study of those activities which, with or without money, involve exchange transactions among people".

- "Economics is the study of how men choose to use scarce or limited productive resources (land, labor, capital goods) to produce various commodities and distribute them to various members of society for consumption".

- "Economics is the study of how mankind goes about the business of organizing its consumption and production activities"

- "Economics is the study of wealth".

- "Economics is the study of how to improve society" (Samuelson 9th ed. 1973 p.3).

Gary Becker (1981) does not speak about economic science, but about "the economic approach", which in his opinion was applicable to all human behaviour. "The economic approach" assumes that individuals maximize their utility from basic preferences that do not rapidly change over time. The economic approach is not restricted to material goods or to markets with monetary transactions but also applies to emotional decisions such as marriage, divorce, 
demand for children, discrimination, and to decisions about the division of time over market and nonmarket production, criminality etc. (Becker 1981 p.xo and xi). Hirshleifer criticises the imperialist expansion of economics into the traditional domains of sociology, political science, anthropology and social biology as being one-sided and pointed out that ultimately it would be impossible to carve a distinct territory for economics. "Economics impenetrates them all and is reciprocally penetrated by them. Good economics will also have to be good anthropology and sociology and political science and psychology" (Hirshleifer 1985 p.53).

Pen (1995) compares economic science to a ring-shaped biscuit: utility is the central phenomenon in economic science. Because utility is a psychic phenomenon, a subjective feeling, economists cannot quantify, cannot measure this central phenomenon. Utility is like the hole in the biscuit (Pen 1995 p.220).

In Robbins' (1962) and Becker's (1981) definition there is no distinction between economic and non-economic activities. Robbins counted all human behaviour which was influenced by the tension between ends and scarce means with alternative uses as belonging to economic science. Both in Robbins' and in Becker's definitions economics is one of many aspects of human behaviour and there is no clear distinction between economic and non-economic activities. The discussion about economic imperialism makes clear that other than economic motives underlie human activities such as habits, institutions, psychological, religious and ethical motives. These motives can be very strong and more important than economic motives. A multi-disciplinary approach or an approach which implements other than economic motives in economic models is recommended.

Nelson (1993) suggests, following Georgescu-Roegen, that the primary objective of economic activity is the self-preservation of the human species, including the survival of childhood. In this concept non-material services such as attendance to health care and care for children, sick and elderly people become just as ceritral to economic science as food and shelter.

Nelson proposes to define economics as: "the study of how humans in interaction with each other and the environment provide for their survival and health" (Nelson 1993 p.34). This definition includes without doubt human activities such as household work, care for the family, do-it-yourself activities and voluntary work, which were classified as unpaid work according to Juster and Stafford (1985). Other activities were classified by them as paid work, personal care or leisure, as was mentioned earlier in the Introduction to this study. The classification of activities will follow hereafter. 


\subsection{Production or consumption}

The next question is whether unpaid labour can be classified as a productive activity, a consumptive activity or both. Older economists' ideas on economic science are reflected in their ideas about the production boundary. The so-called Physiocrats for example, a stream in economic theory building during the eighteenth century, showed that they thought only land could produce wealth, because land was the only source of growth of agricultural products. "La terre est l'unique source des richesses" (The soil is the only source of wealth). In their eyes only agricultural labour was productive. "Le travail, porté partout ailleurs que sur la terre est stérile absolument, car l'homme n'est pas créateur" (Labour is only productive in agriculture, because mankind is not creative) (Quesnay as quoted by Zimmerman 1955 p.42).

In the views of Adam Smith (1776), the "father" of economic science, only material goods increased welfare. The labour of household staff, doctors, writers and all those people who produced services which "generally perish in the very instant of their performance" was not productive in Smith's eyes and did not have value because it "does not fix and realize itself in a permanent subject or vendible commodity". This is the so-called "classical" view on production (Smith 1776, Penguin ed. 1976 p.430). This narrow concept of production is one of the reasons why economic science neglected unpaid (household) services for a long time.

Jean Baptiste Say (1767-1832) judged that all labour which produced utility was valuable, even if the product was not a good but consisted of a service. However, he restricted the production boundary to goods and services which could be exchanged in a market (Zimmerman 1954 p.62). This limitation, excluding nonmarket goods, is another reason why economic science neglected unpaid work for a long time.

John Stuart Mill (1848) distinguished three kinds of utilities produced by labour: utilities fixed and embodied in outward objects, utilities fixed and embodied in human beings and utilities not fixed or embodied in any object, but consisting merely of a service rendered. In principle he considered productive those exertions which were embodied in material objects. However: "I shall not refuse the appellation productive to labour which yields no material products as its direct result, provided that an increase of material products is its ultimate consequence". For example the labour of teachers, physicians and government officials was regarded by him as such (Mill 1848, reprint Kelly 1965 p.46-48).

One of the first authors, before Becker, who proposes to extend the production boundary to unpaid labour was Margaret Reid (1934)(5). She proposes to extend the production boundary to "those unpaid activities which are carried on by and

\footnotetext{
5 A first start in this discussion was given by Wesley Mitchell (1912) in a comparison between the activities of a housewife and those of professional businessmen which ends: "there is a schema of values embodied in every housewife's work, whether she knows it or not".
} 
for the members of the household, which activities might be replaced by market goods or paid services, if circumstances such as income, market conditions, and personal inclinations permit the service being delegated to someone outside the household group" (Reid as quoted by Eisner 1988 p.1621). To my knowledge she is the first author who formulated the third person criterion.

I add two remarks to this definition:

1. Reid speaks about "activities which are carried on by and for the members of the household", thereby excluding voluntary activities which are undertaken for persons in other households. In my opinion such activities should be included because they have the same characteristics: they comprise unpaid household work, care for children and sick or old people, do-it-yourself jobs for other households and voluntary (management) activities for political or welfare organizations or unions.

2. Unpaid work is done by individuals who do not or cannot work on the labour market because legal or unwritten rules exclude them (too young, too old, housewives, handicapped or unemployed persons). So the individuals actually rendering these services often cannot obtain a market wage. Yet they represent a value because they can, if necessary, be replaced by market goods or paid services(6). In my opinion the third person criterion is a synonym for dollar value. Unpaid work comprises the dollar value of household work, care for children and other members of the family, do-it-yourself activities and voluntary unpaid work like organized and unorganized care for family and non-family, participation in political and social organizations, church, etc. This question of the value of unpaid work by people not participating in the labour market will also be dealt with in chapter 4 .

The "third person" criterion has meanwhile been accepted by most experts, although Chadeau (1992) remarks that the third party criterion comes up against borderline cases such as to transport oneself, which would be a productive activity if connected with paid work and a non-productive activity if connected with leisure (Gronau 1977 p.1104; Hawrylyshyn 1977 p.87; Hill 1977 p.326; Adler and Hawrylyshyn 1978 p.334; Gershuny and Robinson 1988 p.544; Chadeau 1992 p.89; Schäfer 1992).

Another discussion in economic science deals with the contribution of education to national output: the so-called human capital revolution (Freeman 1986). If time spent on education is considered an investment which increases one's future productivity and earnings, it is a productive activity. This does not rule out the possibility that education includes important consumption components (Freeman 1986). Some people use their education for leisure activities, others sparsely or never use their educational experiences on the labour market because they are too old or handicapped.

\footnotetext{
6 Hawrylyshyn thought only the dollar value was important to economists and wished to exclude satisfaction like parental pride or well-being like love (Hawrylyshyn 1977 p.87). Gronau spoke of a "close substitute in the market" (1977 p.1104). Although for an economist the dollar value is determined by the market, the personal relationship cannot be replaced by the market substitute.
} 
Opinions differ whether time spent on education should be considered consumptive or productive. Juster spoke about investment of time and subdivided it into seven categories including formal and informal training, helping children to make or do things etc. Besides that he thought that half of the time spent on walking, cycling, jogging and hiking should be seen as an investment of time in one's health (Juster 1985 p.186). Yet he classified studying as a leisure activity, whereas medical and non-medical help and care for other adults should in his view, be classified as personal care (Juster 1985 p.331).

Hawrylyshyn (1977) classifies time spent on education as "productive" (Hawrylyshyn 1977 p.80). He is opposed by Hill (1977): "Mental processes such as thinking, learning and studying cannot be performed by others and cannot be treated as productive in an economic sense. The time and efforts spent by students should not be treated as equivalent to the labour of workers. The boundary of production is correctly drawn in education between the teacher who produces and the pupil who consumes the services produced". (Hill 1977 p.323326). The Dutch Social and Cultural Planning Office (SCP) does not consider education unpaid work (Juster 1985 p.330; Knulst and Schoonderwoerd 1983 p.269). I follow the SCP's definition.

Ideas about consumption have also changed in the course of time. John Stuart Mill made a distinction between productive and unproductive consumption. Following Adam Smith in his concept of productive and unproductive labour, Mill applied the distinction between productivity and unproductivity to consumption as well. In his opinion the only productive consumers were productive labourers, but not all consumption by productive labourers was productive consumption: "that alone is productive consumption, which goes to maintain and increase the productive powers of the community". He thought that a certain quantity of the consumer goods produced in an economy entered as necessary inputs into the production of manpower in the household sector. To his mind productive consumption was an input, being necessary to maintain human capital intact. If wages were at a minimum subsistence level, the whole of the wages bill was required for productive consumption (Blaug 1978 p.190).

Karl Marx continued this line of thought and distinguished "individuelle Konsumtion" and "produktive Konsumtion". "Die Konsumtion des Arbeiters ist doppelter Art. In der Produktion selbst konsumiert er durch seine Arbeit Produktionsmittel und verwandelt sie in Produkte von höherem Wert als dem des vorgeschosznen Kapitals. Dies ist seine produktive Konsumtion. Andrerseits verwendet der Arbeiter das für den Kauf der Arbeitskraft gezahlte Geld in Lebensmittel: dies ist seine individuelle Konsumtion."(7) (Marx I p.596). "Daher betrachtet der Kapitalist nur den Teil der individuellen Konsumtion des Arbeiters als produktiv, der zur Verewigung der Arbeiterklasse erheischt ist, also

7 The consumption of the labourer is twofold. In the act of production he consumes the means of production and changes them into products of greater value than the advanced capital. This is his productive consumption. On the other hand he uses his wage to buy food: that is his individual consumption. 
in der Tat verzeht werden musz, damit das Kapital die Arbeitskraft verzehre; was der Arbeiter auszerdem zu seinem Vergnügen verzehren mag, ist unproduktive Konsumtion"(8) (Marx I p.598). In so far as labour force was regenerated by individual consumption, individual consumption was also productive in Marx's opinion.

The discussion about "productive consumption" did not return in economic literature until the second half of the twentieth century, when Becker (1965) wanted the full integration of so-called "productive" consumption into economic analysis. I will return to Becker's analysis in the next section.

Before Becker's time consumption was usually defined as the expenses for consumption goods by the household in such a way that the utility of the household was maximized. Traditional theories did not pay attention to the fact that shopping and spending money on consumption goods is an activity which costs time and energy; that a meal does not appear on the table by itself; that clothes bought in a shop do not stay clean and crisp without time and energy spent on cleaning and washing, activities mostly done by women. Thorstein Veblen remarked that "the lady of the house is, according to the ideal scheme of the pecuniary culture, the chief menial of the household" (Veblen as quoted by Galbraith 1973 p.79).

In the National Accounts national consumption consists of consumptive expenses of households and government. Consumption is defined in the National Accounts as the use of goods and services for non-productive purposes.

So unpaid work in and for households is neither counted as production nor as consumption. If unpaid work is considered a productive activity, the definition of consumption also changes. All productive activities increase income in kind and, as long as no distinction is made between consumption and investment in the household accounts, consumption is increased by the same amount as production.

The definition of consumption used in this study is the using up of goods and services bought on the market and/or produced at home in conformity with the third person criterion. A more detailed discussion on investment in households can be found in chapter 5 .

There are several reasons why unpaid work used to get and still gets little attention in economic literature. The concept of economic science and the ideas about production and consumption have already been mentioned. A second reason why unpaid work was considered to be neither a productive nor a consumptive activity is that these activities are difficult to quantify. Economists want to quantify the economic ideas and concepts. Money is a common

8 The capitalist uses only that part of the individual consumption of labourers as productive that keeps labourers as a social class intact; that part of the consumption that labourers use for pleasure is considered unproductive consumption. 
denominator, which makes it possible to compare and add different goods and services, to measure welfare, to analyse costs and benefits. In this respect it is much easier and more efficient to consider only paid work as an economic activity.

A third reason why unpaid work got so little attention is the era in which economic theory was developed. The publication of Adam Smith's "Inquiry" in 1776 is often taken as the beginning of Economic Science. In the eighteenth and nineteenth century household work for the higher classes was mostly done by underpaid staff. It was not regarded as a profession of high prestige, as one can read in Adam Smith's "Inquiry". That was probably one of the reasons why Smith and his contemporaries did not consider these services to be "productive" ones.

A fourth reason is that since the publication of the "Inquiry", economic science has mainly been developed by men who did not do unpaid work themselves and took it for granted that staff took care of the household chores and wives stayed at home to look after children and household. Most people pay little attention to things they do not have to do themselves. Economists are no exception to that rule.

As a consequence unpaid work was seen neither as production, nor as consumption until the nineteen sixties, when the idea of the "New Home Economics" was developed by Mincer, Becker, Gronau and others(9) .

\subsection{The allocation of time: a microeconomic model}

Traditional economic theory is based on the assumption that people maximize their welfare by maximizing a utility function

$\bar{U}=\mathrm{U}\left(\mathrm{X}_{1} \ldots, \mathrm{X}_{\mathrm{n}} ; \mathrm{L}\right)$

where $\mathrm{X}$ denotes goods and $\mathrm{L}$ is leisure time. The utility function is subject to the budget constraint:

$\Sigma P_{i} X_{i}=w(T-L)+V$

where $\mathrm{P}_{\mathrm{i}}$ is the price of good $\mathrm{X}_{\mathrm{i}}, \mathrm{T}$ is total time available, $\mathrm{w}$ is the wage rate and $\mathrm{V}$ is other income (Gronau 1986 p.274).

People divide their time between the labour market and leisure activities in such a way that marginal utility of the last hour on the market equals the marginal utility of the last leisure hour. The net marginal wage of the last hour on the labour market is decisive for the labour market supply of individuals. This net

9 Earlier the German philosopher Christian Wolff (1679-1754) identified the household as the locus of production and for that reason as the central unit of analysis (Backhaus 1989). 
marginal wage is also decisive for the evaluation of unpaid work, if unpaid work is seen as the alternative for paid work.

Mincer (1962) was the first economist to remark that the dichotomy between work and leisure is not true, not even in the case of adult males. "The logical complement to leisure is work broadly constructed, whether it includes remunerative production in the market or work that is currently not paid for" (Mincer 1962, reprint Penguin 1980 p.43). As such he mentions educational activities of boys and girls and work at home by women.

In Becker's view (1965 p.494) the source of utility is not goods and services purchased on the market, but "commodities" produced at home by combining different market goods with time. Becker does not make a distinction between "leisure" and "consumption" time on the one hand and time spent on household services on the other hand.

$\mathrm{U}=\mathrm{U}\left(\mathrm{Z}_{\mathrm{i}} \ldots, \mathrm{Z}_{\mathrm{n}}\right)$

where $Z_{i}$ denotes the ith commodity and each commodity is a combination of goods $\left(\mathrm{X}_{\mathrm{i}}\right)$ and consumption time $\left(\mathrm{L}_{\mathrm{i}}\right)$.

$\mathrm{Z}_{\mathrm{i}}=\mathrm{f}_{\mathrm{i}}\left(\mathrm{X}_{\mathrm{i}}, \mathrm{L}_{\mathrm{i}}\right)$

Instead of dividing their time between labour and leisure, households divide their time between paid and unpaid (household) labour and leisure. Utility maximization is subject to two constraints: the budget constraint and the time constraint. The old dichotomy of time used for work or for leisure has been replaced by a trinity of time use: paid work, unpaid work and leisure (Becker 1965 p.495; Gronau 1977 p.1100). Becker's article: "A theory of the allocation of time" was very important to a new view on economic science. In Becker's view households are both production units and utility maximizers. "In recent years economists increasingly recognise that a household is truly a "small factory": it combines capital goods, raw materials and labour to clean, feed, procreate and otherwise produce useful commodities" (Becker 1965 pp.495/496).

At about the same time as Becker, Lancaster (1966) independently developed an idea about consumption, which only slightly differed from Becker's, namely that goods are not the direct objects of utility but that consumers derive utility from multiple properties or characteristics of purchased goods. A good will have more than one characteristic and many characteristics will be shared by more than one good. At the same time if goods are combined they may possess characteristics different from those pertained to the separate goods. A meal, for instance, possesses nutritional characteristics, but a dinner party may possess nutritional characteristics and aesthetic and perhaps intellectual characteristics different from the combination obtainable from a meal and a social gathering consumed separately. Even a single good may possess more than one characteristic, so that 
the simplest consumption activity will be characterized by joint outputs (Lancaster 1966 p.133 and 134).

Becker's theory does not distinguish between productive and consumptive activities. Gronau makes the distinction between production and consumption, following Reid (1934), in defining work at home as a productive activity for which one could hire someone else to do it, the so-called third person criterion. In an extreme case, work at home and work on the market are perfect substitutes; a person is indifferent to the composition of the goods and services he consumes, whether they are produced at home or purchased on the market. To put it formally, assuming a one period and a one person household, the household maximizes the commodity $\mathrm{Z}$ (equation 3 ), which is the output of home production with goods $X$ and consumption time $L$ as inputs (equation 4) (Gronau 1986 p.282).

The goods can either be produced at home $\left(X_{h}\right)$ or purchased on the market $\left(X_{m}\right)^{(10)}$. The two kinds of goods are perfect substitutes:

$X=X_{h}+X_{m}$

The person can secure the goods either by selling time on the market at a fixed real wage $\mathbf{w}:$

$X_{m}=w N+V$

where $\mathrm{N}$ denotes market work, or by producing them at home subject to diminishing marginal productivity:

$\mathrm{X}_{\mathrm{h}}=\mathrm{f}(\mathrm{H})$

where $\mathrm{H}$ denotes work at home.

The ultimate constraint is the time constraint:

$\mathrm{L}+\mathrm{H}+\mathrm{N}=\mathrm{T}$

In figure 2.1 time is put on the horizontal axis and output on the vertical one. Figure 2.1 represents a household production function with increasing and decreasing returns when more time is used. If, for example, only one hour a week is available for house cleaning, only a small part of the house will become cleaner, the rest of the house will become dirtier. The use of more cleaning time will lead to increasing returns until a certain point is reached. After this point more cleaning time will lead to decreasing returns: the level of cleanness per

10 In this model no distinction is made between market goods or time for different purposes. In reality market goods are bought for feeding, clothing, recreation etc. and time is spent on cooking, child care etc. A first step to refine models of time allocation was set by Kooreman and Kapteyn (1987) who distinguished seven activities. 
hour extra will decrease. The magnitude and shape of the production function will differ between persons depending on individual talents and experience.

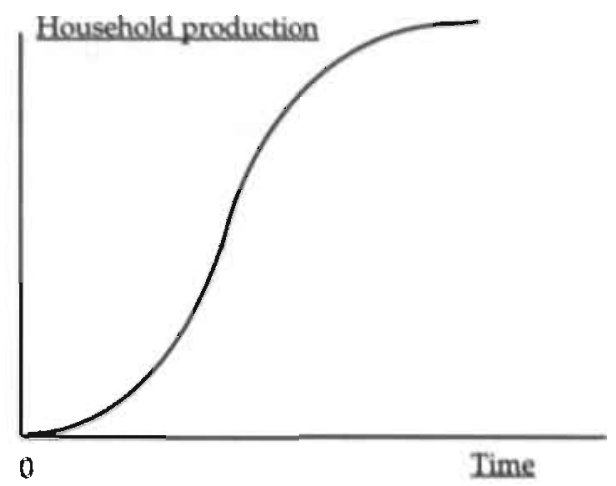

Figure 2.1.

The role of goods $\mathrm{X}$ is shown in figure $\mathbf{2 . 2}$.

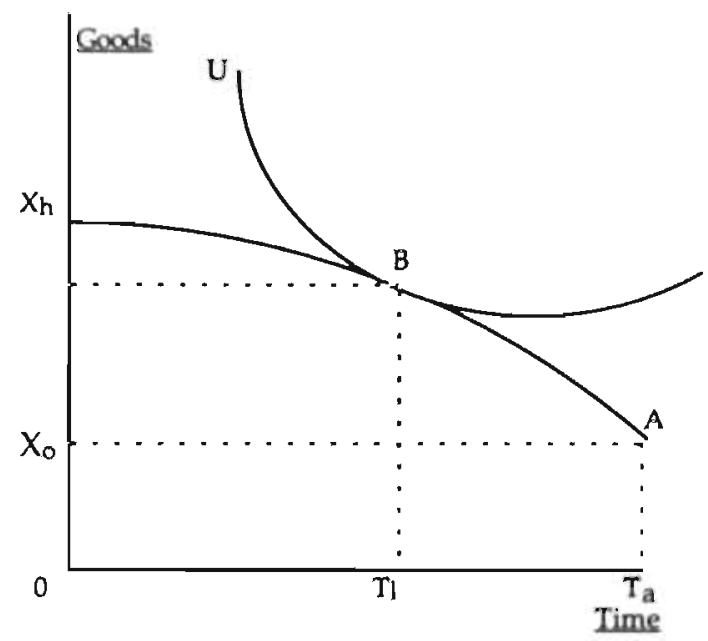

Figure 2.2.

In figure 2.2 home production of a person not working on the labour market is illustrated in the curve $X_{h}-A$. The person has a non-labour income $X_{0}$. If this non-labour income is spent on market goods, a consumption level of $X_{0}$ and leisure $T_{a}$ is reached. 
The ultimate constraint is the time constraint:

$\mathrm{T}=\mathrm{T}_{\mathrm{pc}}+\mathrm{T}_{\mathrm{h}}+\mathrm{T}_{\mathrm{l}}$

where $T_{p c}$ is time for personal care (not shown in figure 2.2.)

$T_{h}=$ time for home production. $T_{l}=$ leisure time

Time available for home production and leisure is:

$\mathrm{T}_{\mathrm{a}}=\mathrm{T}-\mathrm{T}_{\mathrm{pc}}$

(not shown in figure 2.2)

If the person does not work on the market, because his potential wage rate is low or because he is too young, handicapped or too old to work on the market, an optimum is reached in point B, where the home production possibility curve (equation 5) reaches the highest possible indifference curve of a combination of consumption goods and leisure time. The person whose preferences are shown in figure 2.2. is indifferent to all combinations of consumption goods and leisure time on this curve. The preferences of individuals, and hence their indifference curves (equation 3) will vary according to their age, sex, education, mental attitudes etc. For older women, for example, it is self-evident that a lot time is spent on a clean house whereas a young single male is more interested in spending time on sports, paying visits and dancing.

In point $\mathrm{B}$ the marginal value of one hour of home production of this person (figure 2.2.) equals the marginal value of one hour of his leisure time (Hagenaars and Wunderink 1990 p.134). The person's time is divided between leisure time, $\mathrm{O}-\mathrm{T}_{1}$ and time spent on home production, $\mathrm{T}_{1}-\mathrm{T}_{\mathrm{a}}$.

If the person works on the market, he can buy consumption goods by earning an income on the labour market at a fixed real wage, $w$. In this way he can expand his consumption for a higher indifference curve can now be reached. In point $B$ in figure 2.3 the wage rate equals the marginal value of leisure time. In point $C$ the wage rate equals the marginal value of home production, so this person spends $0-T_{1}$ hours on leisure, $T_{1}-T_{h}$ hours on the labour market and $T_{h}-T_{a}$ hours on home production (Gronau 1986 p.283; Hagenaars and Wunderink 1990 p.133).

What happens if non-labour income decreases? $X_{02}$ is lower than $X_{01}$. The production function does not change, so the same amount of time is spent on home work. The loss of income leads to less leisure time $\left(0-\mathrm{Tl}_{2}\right)$ and more time on the labour market $\left(\mathrm{Tl}_{2}-\mathrm{T}_{h}\right)$. 


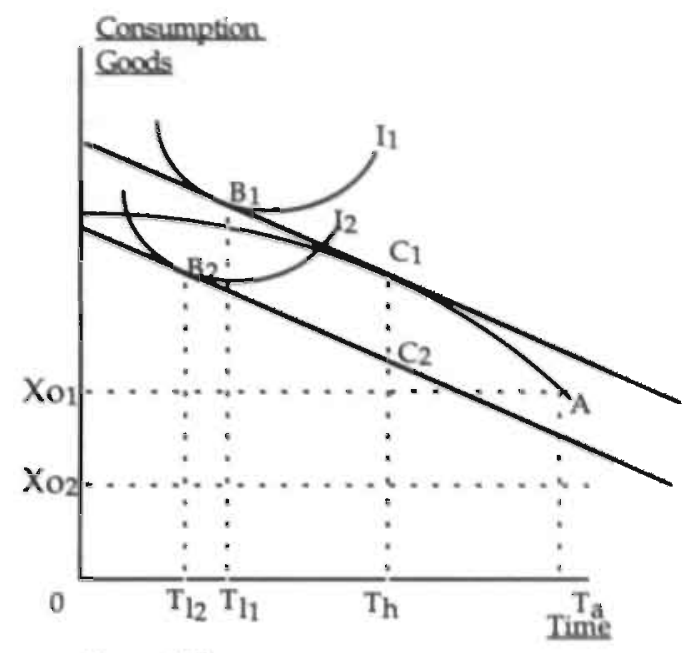

Figure 2.3.

What happens if the production function changes because extra work at home has to be done, for example when a baby is born? The production function shifts upwards (figure 2.4.). If preferences do not change, leisure time remains the same, but time spent on the labour market decreases with $\mathrm{Th}_{1}-\mathrm{Th}_{2}$, because the marginal value of home production has increased.

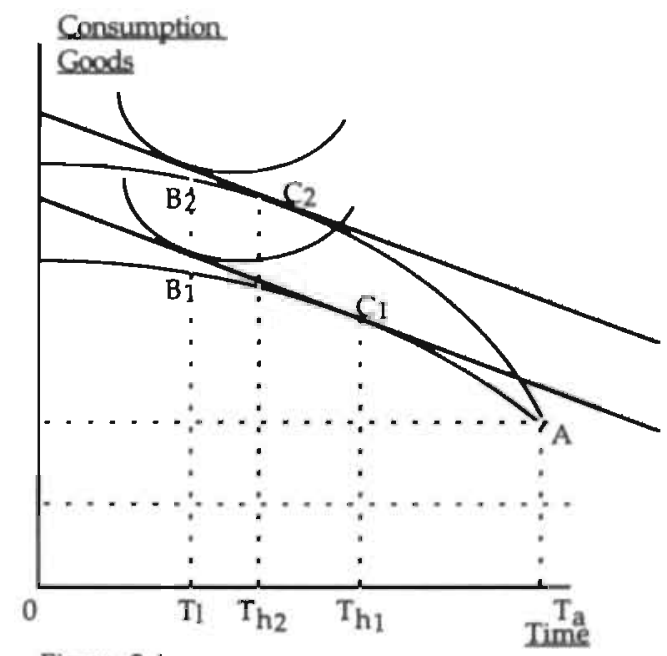

Figure 2.4.

Pollak and Wachter oppose the view that there is a "household production function" (Pollak and Wachter 1975). They argue that the household's technology 
does not have constant returns to scale and joint production, so that the price of the commodities produced by the household depends on the household's preferences and therefore fail to serve the traditional role in consumer theory. Technically, they argued, the household devotes time to activities which are both input and output. The household derives utility or disutility from the time it devotes to each activity as well as from the nominal "commodity output" of the activity (Pollak and Wachter 1975 p.255/256/276).

Hawrylyshyn (1977) agrees with Pollak and Wachter that many consumption goods are used for the joint production of several commodities e.g. a stove that produces nutrition and gourmet pleasures, the house that provides shelter, rest and recreation. He thought that the problem was more a theoretical than an empirical one: one hour of time can be valued by wages. He thought that the jointness in production was best expressed in the notion that an hour of time spent on such activities produced both "direct" and "indirect" utility. Direct utility is the pleasure, the satisfaction that work can give. Indirect utility is the market price of the goods or services produced.

In the same article Hawrylyshyn makes clear that there is a minimum amount of time that a household must combine with each unit of goods to produce a basic commodity. The household may, and sometimes does devote more time. Hawrylyshyn took as an example a small-town professor with a love for old stone farm houses, who devoted 1000 hours a vear to restore an old farm house, whereas the minimum time required to do this job is 500 hours. The 1000 hours produce both direct utility for the professor's mental relaxation (500 hours) and indirect utility in the form of housing (also 500 hours). "Thus results of household behaviour which are themselves utility, such as parental pride, cultural and esthetic satisfaction should be explicitly excluded from evaluation. Child care values must exclude the satisfactions of developing effective human beings, but may include the teaching of accepted social mores. Spouses' "services" would include meals and clean shirts, but exclude personal. affection and companionship. To respond immediately to the inevitable jokes about market replaceability for conjugal relations, let it be said that of course one can find a market alternative price for sex in dollar terms, but this has little relation to, and does not change the fact that the price of love is, well, love" (Hawrylyshyn 1977 p.85/87).

Hill(1979) does not share this view. "The amount of direct satisfaction which an individual derives from the production of a good or service, whether for the market or not, cannot affect the measurement of the good or service itself. Many employees or self-employed workers derive a great deal of personal satisfaction and sense of achievement out of the goods they create or services they provide for. The satisfaction they derive is quite separate from the output they produce. Similarly, the fact that many do-it-yourself activities are undertaken as a form. of recreation is irrelevant when it comes to the measurement of the goods and services produced. It cannot be blandly assumed that leisure provides satisfaction while work does not." (Hill 1979 p.35 and 37). In her view the magnitude of 
nonmarket goods and services can only be measured by looking at their output (Hill 1977 p.325). Indeed, intrinsic satisfaction is not a phenomenon exclusively observed in unpaid work. In several countries data have been collected which showed that paid work is associated with very high levels of intrinsic satisfaction, even higher than most. leisure activities (Juster 1985 p.336; Juster and Stafford 1991 p.511; Flood and Klevmarken 1992 p.4).

Hill makes these remarks in two articles on the concept, definition and measurement of a service. Her thorough analysis is of great importance to the subject of unpaid work. However, it is difficult to measure the output of household production in exact physical quantities. For that reason evaluations of household production are practically always made on the basis of the time household producers use as an input. Hill did not agree with the input method. The question whether to use the input or the output method to evaluate household production will be dealt with in chapter 3 .

In his microeconomic model Gronau (1986) assumes a one-period, one-person household. He ignored the sharing of goods, the pooling of resources and the division of work between members of the family. In conventional labour supply models it is assumed that the family is the decision making unit. However, families are made up of individuals: so where do family utility functions come from? Several answers are possible:

1. All members of the family conform to the preferences of the family head. This is not a likely solution in emancipated industrialized countries.

2. Social choice conditions for the existence of a well-behaved family utility function are fulfilled. Such existence conditions are rather stringent, so this solution is not convincing either.

3. Family members care for each other in the sense that intrafamily resource transfers do exist (Killingsworth and Heckman 1986 p.130). Becker introduced the altruistic family member. Altruistic means that a person's utility function. (the husband in Becker's view) depends positively on the well-being of another family member (the wife). The husband does spend some of his income on the wife rather than on his own consumption (Becker 1981 p.173). However, it is not realistic to think that caring and intrafamily transfers eliminate all conflicts between family members.

4. Leuthold (as quoted by Killingsworth and Heckman 1986) solved this problem by supposing that each individual family member maximizes his or her own individual utility, given the decision of other members of the family about. their leisure time. Family members pool their incomes, derive utility from family consumption subject to the family budget constraint.

A variation of this model is the male-chauvinist model, in which the husband's income is taken into account by the wife in her labour market decision, whereas the husband disregards his wife's (possible) contribution to family income. In my opinion the male-chauvinist model fits in for late twentieth century industrialized countries where the responsibility for household and child care rests with the wife. 


\subsection{The price of unpaid work in economic theory}

The value people place on their time affects the optimum combination of inputs in home production, the price they assign to the products of homework and the amount of these products. Gronau (1986) distinguishes two methods to evaluate the unpaid work done by family members at home:

a. market opportunity costs, that is the price this time would have commanded if the unpaid time would have been spent on the labour market;

b. the market alternative, that is the price it would have cost the household to purchase the same services on the market. Variations are used for opportunity costs as well as for market prices.

The model underlying the opportunity costs approach stands for the individual choosing between spending his time on the labour market or at home. In this case the rational individual allocates time in a way that marginal net wages are equal to the marginal returns from unpaid household work as he perceives them (point $C$ in figure 2.3).

Murphy (1982) mentions the following variations for opportunity costs:

a. average market wages; b. aftertax wages; c. aftertax wages minus certain work-related costs. She does not explain the reasons. Chadeau (1992) used net average wages, gross average wages and gross average wages plus employer's contribution in social security, in both the opportunity cost approach and in the market cost approach (Chadeau 1992 p.97).

Gronau (1986) points out that the major objection to evaluation of opportunity costs is the "homemaker's paradox". The value of the same household task done by say a former professor in microbiology and a former stenographer, whose potential wage rate is one quarter of the potential wage rate of the professor, would be four times as high. Gronau explains this paradox by supposing that the microbiologist and the stenographer must be deriving different utilities from their home and market jobs. Traditional measures of market output do not incorporate a measure of workers' "job satisfaction" and, by the same token, should not include a measure of their enjoyment from work at home. A person's market wage differs from the value of his marginal productivity at home and should not be used to measure home outputs (Gronau 1986 p.297).

The model underlying the market cost approach is more production-orientated, designed to augment GNP by the value of home production. Murphy (1982) mentioned two variations for the market cost approach: a. replacement cost if the homemaker is replaced by a single market replacement; b. service cost if the homemaker is replaced by a variety of market specialists. Chadeau (1985) used the cost of a general housekeeper or the cost of a variety of trained workers.

Chadeau's alternative approach was to value household output at the price of equivalent goods and services available on the market and to subtract intermediate consumption of the household as well as fixed capital consumption 
(Chadeau 1985 p.242). This line of thought is continued by Goldschmidt (1993), who remarked that household's productive time should be valued in relation to the imputed market value of the labour time of the product. However, for some activities the physical output is difficult to measure or cannot be compared to market services. Care for sick children for example can only be measured in time inputs. The same applies to shopping. Even if the physical output can be measured, the quality and the circumstances of these activities at home differ very much from the market services.

The growing labour market supply of women in many Western countries in the second half of this century has given rise to research and scientific publications about women deciding to participate in the labour market. Mainstream economic theory states that women decide to participate in the labour market if net marginal wages on the labour market become higher than the reservation wages. The reservation wages are the minimum wages which induces a nonworking person to join the labour force (Gronau 1986 p.295). If, as Ferber and Greene (1983 p.152) pointed out, full-time homemakers are not acquainted with the wages they can expect on entering the labour market, researchers can assume that they would receive wages related to their education and labour market experience. This is considered their reservation wage. The reservation wage of other groups who are not acquainted with their reservation wage either, because the law, their age or their health do not allow them to work on the labour market such as youngsters, elderly or handicapped people, is estimated in a similar way as the reservation wage of full-time homemakers as will be shown in the next paragraphs.

Another approach to estimate the price of the time of people not working on the labour market is to distinguish several categories in the population. Nordhaus and Tobin (1972), for example, divide the population into five categories: employed, unemployed, housewives, students and others. The average hourly earnings in manufacturing are supposed to represent the nominal value of time for the employed. Nordhaus and Tobin put the question whether the unemployed should be treated as having zero wages. They debate that the wages of frictionally or voluntarily unemployed should be close to the market wage rate. On the other hand, during a great depression most unemployed people cannot obtain work at anywhere near the prevailing wage. Their compromise was to assign a zero wage to normal working hours of the unemployed, but to value their nonmarket working hours at the going wage. To females they assign the average hourly earnings for women, to students the wage for the age group under 20 years of age, and for people over 65 years of age the wage for this age group (Nordhaus and Tobin 1972 p.45/46).

Jorgensen and Fraumenie, as quoted by Eisner (1988) impute a wage of zero for those under 15 and over 74 , because they are presumed to fall outside the scope of the labour market (Eisner 1988 p.1637). Bonke, as quoted by Brathaug (1991), put the wage for non-employed people at zero in his calculations of the value of unpaid work based on opportunity costs. He assumes: "that the non-employed 
who do not want or are unable to obtain employment are therefore without a market wage alternative" (Brathaug 1991 p.18).

Assigning a price of zero or nearly zero to home production of people not working on the market does not seem right regarding the welfare it produces. A consumer who does not work on the labour market has the choice to produce a consumption good at home or to buy the good on the market, assuming that the two goods are perfect substitutes. Traditional economic theory assumes that the ultimate economic goal is consumption. People maximize their welfare, the utility they receive from consumption, by dividing their incomes between different kinds of consumption goods in a way that marginal utility of the last unit of money spent on different kinds of consumption is equal. People who are outside the labour market can maximize their welfare by performing unpaid work and saving expenditure. In the optimum situation the value of their unpaid work is equal to the price of labour of the good or service bought on the market. A consumer will only buy market goods if he values his leisure time more than the market cost. At this point the marginal value of an hour of labour bought on the market equals the marginal value of an hour of home work and also equals the marginal value of an hour of leisure. This is the optimum for youngsters, elderly, disabled and unemployed people. It is the point where the indifference curve reaches the production curve (see point $B$ in figure 2.2) at which point this value will be rather low. Only very rich people who do not work on the labour market will put a high value on their leisure time and have little home production.

In my opinion the opportunity costs method is an appropriate method to decide what time to spend on the labour market, but not useful to estimate the value of home production. A first argument, Gronau's "home maker paradox", has been mentioned earlier. A second argument to reject the method of opportunity costs is that the average productivity on the labour market will be higher than in home production, because functions on the labour market tend to become more specialized. A third argument is that the opportunity costs method uses net wages instead of gross wages plus employer's contribution in social security as is usual in National Accounts. The contribution of government workers, for example, is estimated at gross wages pius employer's contribution in social security (SN 1991 b p.194). At the point where the marginal wage is equal to the marginal cost of a good or service bought on the market, the household compares the net wages it can obtain on the labour market with the (gross) cost of the good or service on the market. Therefore market replacement cost is a better method to estimate the price of home production for working as well as nonworking people.

Floro (1995) points out that "so far non of the present evaluation methods gives an adequate measure of the economic importance of household production". Women's primary social role has an impact on her earning capacity in the market. The biases imposed by social norms on the market wage are reflected on the imputed household wage. Floro concludes: "The vicious circle of underestimation persists as women's economic contribution in the market is 
underrated because of the prevailing notion that their "primary role" is in the household; but their economic contribution in the household is undervalued because their role in the market is considered to be only secondary. As such the imputation of market-based opportunity costs to men's and women's output of labor time is a questionable procedure" (Floro 1995 p 1927).

In my view the cost of a single market replacement of the homemaker, as mentioned by Murphy (1982) and Chadeau (1985) is a better approach than the replacement cost of a variety of market specialists, because the productivity of a market specialist will be higher than the productivity of a non-specialist. So the wages of these specialists overrate the value of home production. Another reason not to use wages of market specialists is that wage scales and definitions of functions change in the course of time, which makes it difficult to compare wages of specialists in different years. For practical reasons I prefer this method over Chadeau's and Goldschmidt's alternatives as has been mentioned earlier. In chapters $4,5,6$, and 7 the costs of a single market replacement will be used for all categories of people doing unpaid work.

\subsection{Summary and conclusion}

In this chapter several definitions and descriptions of economic science by a number of well-known economists have been examined. These definitions have in common that economic science studies human behaviour as a relationship between objectives and scarce productive resources that have alternative uses. In this view all human activities have an economic aspect. This economic imperialism does no justice to non-economic motives which are often much stronger. The primary objective of economic activity is the self-preservation of the human species, including the survival of childhood. Nelson's definition of economics reading: "the study of how humans in interaction with each other and the environment provide for their own survival and health" seems more appropriate than labelling all human activities as (partly) economic.

Using Juster and Stafford's classification of activities (1985) in paid and unpaid work, personal care and leisure, only paid and unpaid work are economic activities. Following Nelson's line of thought and applying the "third person criterion", unpaid work is also an economic activity for people not working on the labour market, because they have to buy less goods and services on the market. By doing unpaid work they can extend their consumption. They divide their time in a way that the marginal value of leisure time is equal to the marginal value of home production. People working; on the labour market allocate their time between work at home, work on the market and leisure time. In economic literature several prices are used to estimate the value of unpaid work. The wages of a single market replacement of the homemaker seems to be the best approach to me. 



\section{METHODS TO VALUE UNPAID WORK}

"The lady of the house is the chief menial of the household"

(Thorstein Veblen in "The theory of the leisure class" 1899).

\subsection{Introduction}

In chapter 2 productive nonmarket activities (or unpaid work) have been defined as activities which produce goods or services yielding utility, which could also be performed by a third person. The cost of a single market replacement of the homemaker has been proposed as the best method to assign a price to unpaid work.

Much discussion in estimating the value of unpaid work is about the "input method" versus the "output method". The input method ascribes money value to labour inputs directly. The hours spent on household work or other unpaid work activities are valued with the help of comparable wage rates. Hours multiplied by comparable wages give an estimation of value added. Fixed capital consumption, net indirect taxes and intermediate goods should then be added to obtain a complete estimation of the value of household production. In practice almost all computations stop after hours of input have been multiplied by wage because no more data are available.

The output approach takes as a starting point gross output based on market prices: for example the number of meals produced at a price in a restaurant. The value added is computed as the residual after subtracting intermediate goods and depreciation of fixed capital (Chadeau 1992 p.90).

The value of goods and services computed by the input approach can differ considerably from the value of comparable products traded on the market. Lützel (1989) compares the output method to the computing method used within National Accounts for the production accounts of non-financial enterprises. He indicated that the input method seems easier to apply than the output method, because more statistical data are available on time use than on the output of unpaid work (Lützel 1989 p.343).

This chapter has been organized as follows: section 2 describes the ins and outs of the input method, section 3 describes the output method. As will be shown in the overview of calculations in literature in section 4 most calculations are limited to net value added. In section 5 summary and conclusion are given.

\subsection{The input method}

In most calculations of the value of unpaid work that have been published so far, 
the input method is chosen as a matter of course. In the first half of this century demographic data, such as the number of (married) women, were chosen as the basis for calculations, because data of time use surveys were not yet available. In the second half of this century data of time use surveys became available as the basis for empirical calculations. As there are many calculations on this basis, they will not be discussed. one by one, but some common problems will be dealt with.

One of the questions researchers had to face was:

Who are to be counted? Mitchell et al. (1921, as quoted by Goldschmidt 1982) wanted to indicate the order of magnitude of housewives' contribution to national income. They took the number of full-time housewives as the volume component. As time use research was not available at that time, they assumed that full-time housewives had a full-time working day. In research by Matolcsy and Varga (1938, as quoted by Goldschmidt 1982) it was assumed that all married women were full-time housewives. When time use data became available, it became clear that besides housewives also other people are productive in the household and that the amount of household work varies with the number and the age of children, the amount of paid work by women, help by members of the family, the health of the housewife and the members of the family (Hawrylyshyn 1976 p.118).

A second problem is that time use studies apply different classifications of activities. But even if the classifications of activities can be compared, researchers have different opinions about which activities should be called unpaid work. Should e.g. gardening or baking a cake be considered unpaid work or leisure time? The difficulties to classify activities as unpaid work will be elaborated on in chapter 4 .

A third problem is that time use studies are not standardized. Sometimes only adults are taken in the sample, sometimes men and women between 15-64 years of age, sometimes all children of 12 years and over as well as adults are included. This problem is solved if the same method is used and the same questions are asked in different time use studies, as is the case in the Netherlands.

A fourth problem is that the method of research is also different. Juster and Stafford (1991) compare several ways of collecting time use data. They conclude that some form of diary is the most valid instrument to measure time use. Survey questions asking people to remember how much time they spent on a certain activity on a certain day, tend to give over-estimated results. A detailed description of activities during a randomly selected one-hour slice of time also gives good results, but is dearer than the diary method (Juster and Stafford 1.991 p.484). Floro (1995) mentions that there is a growing consensus among researchers that the preferred method of data collection on time use involves a chronological record of various activities over the day through the use of a diary instrument (Floro 1995 p.1919). The time use surveys used in this study are diary based: 
A fifth problem is the joint or multiple activities or joint production of two goods and/or services. For example peeling potatoes and watching children or watching TV while ironing. To which good or service should the time input be accounted? If the diary method is followed, respondents will write down the primary activity and only mention the secondary activity if a special question is asked. If the diary method is followed, primary activities may be overrated, secondary activities underrated. If another method of time use research is used, secondary activities can inflate the time estimates to more than 24 hours a day. Research by Hill (1985 a) showed that paying visits and listening to the radio or records are the most dominant forms of secondary activities: they account for $60 \%$ of the time spent in secondary activities (Hill 1985 a p.140). The time use studies used in chapter 4 are based on the diary method so the problem of primary and secondary activities does not arise.

A sixth problem is the difference in time use between working days and Sundays and holidays, the seasonal and cyclical variations in time use. To be able to estimate yearly activity patterns, surveys should have a certain length and be spread over the year. In the time use studies used in this book respondents were asked to fill in a diary during a whole week in autumn, so the data do not reflect a annual activity pattern.

A seventh problem is the production of "collective services". Hiil (1977) points out that "the amounts or quality of collective services must be a function of the number of economic units consuming the services, given that a service itself is a change in the condition of an economic unit". She continues: "The more units affected, the greater the output, irrespective of the activity of the producer. The activity of the producer is not the service. Whenever the number of economic units consuming a collective service is below capacity the producer is operating inefficiently or inside his production possibility frontier" (Hill 1977 p.332/333). This pleads against the input method: using the same time input the cleaning of a house for a family of two persons consumes less time than the cleaning of a house for a family of six persons. The number of persons benefiting from these "collective" services in the home varies per household and varies in time. In my opinion it is very difficult to relate these collective services inside the home to the number of persons who benefit from it because of lack of data.

The eighth problem is whether there are scale economies in home production. Gronau (1986) remarks that studies are unanimous in concluding that there are substantial returns to scale in consumption: "three people do not need proportionally more bathrooms or cars than two people; buying and cooking food in bulk is cheaper; clothes can be handed down from older to younger children" (Gronau 1986 p.289). As there is disagreement on the magnitude of scale economies, Gronau concluded that this question was insoluble, so they are neglected in this study.

In a Dutch time survey (Knulst and Van Beek 1990) it is conciuded that each person less in a household costs one hour of unpaid work less a week for 
preparing meals and half an hour less for house cleaning (Knulst and Van Beek 1990 p.97) If economies of scale exist and can be quantified, should it have influence on estimations of the value of unpaid work? The answer is no. People have clear preferences about living alone or in couples or in more people households. I am of the opinion that if these preferences and the returns of scale resulting from this decision lead to differences in household production and consumption, these differences form an integral part of the way people want to live. If a person prefers to live in an expensive apartment, he pays a high price in money. If he prefers to live alone, he pays by spending more time on his household production.

The ninth problem is the measurement of productivity of unpaid work. Nobody supervises the unpaid worker. Nobody discharges the voluntary worker or housewife if he or she is inefficient or a chatterbox. No calculation of the costs or registration of the quality of household work takes place which resembles the procedures of work on the market place (Broekman 1980 p.269). Does the improvement of household technology, schooling, health and on-the-job training influence productivity of unpaid work as it does influence paid work? Hawrylyshyn (1976) thinks that differences in efficiency may be at the heart of the difference between high and low time estimations. Working wives are considered to be more efficient. Women not working on the labour market have all day to fill up with housework, he concluded from research by Vanek published in 1969. Whether this nhservation still held for the nresent, the considered to be an unanswered question (Hawrylyshyn 1976 p.116).

Fitzgerald and Wicks (1990) compare the price of a certain household task in the household (average time households needed for a certain household task multiplied by an appropriate market wage) and the price commercial firms charged for this task. In this way they compared for example the price of loads of laundry and electrical repairs. Their report does not clearly show how this comparison was done, but they concluded that commercial and household productivity differed: for 15 activities commercial productivity was higher, for 2 activities household productivity was higher, for 25 activities no significant difference could be found (Fitzgerald and Wicks 1990 p.132-141).

However, productivity also differs in paid work. A study by Stafford and Duncan (1985) shows that $9 \%$ of time at paid work is spent on formal or informal work breaks, so even paid workers do not work every minute of their paid time. (Stafford and Duncan 1985 p.254). Research by Vanek (1980) shows that full-time housewives spent 29 hours more on household production than employed wives (Vanek 1980 p.87): Recent research of Dutch time use data confirm Vanek's findings. In 1990 a full-time housewife with children spent nearly 21 hours a week more on household duties and child care than a working mother (Van der Lippe \& Niphuis-Nell 1994 p.25). On the issue of productivity Chadeau and Fouquet (1981) remark that women with an outside job do not have time to chatter or do their home work inefficiently. Full-time housewives have more children, so they have more homework (Chadeau et Fouquet 1981 p.33). 
Because relevant data are lacking, differences in productivity are not reflected in the computations of chapter 4 . On a macro level this does not seem a serious problem because the inefficiency of some people will be compensated for by overefficiency of others.

The tenth problem is a special one, put forward by Zienkowski (1991), concerning productivity in former Communist countries. He thinks that time spent on queuing for purchases should not be regarded as an activity that creates gross domestic product, although it can certainly not be treated as free time but should rather be considered unpleasant work. And what about time spent in lighting fires, carrying coal, wood and water? About 10 to $15 \%$ of total unpaid working time in Polish households is spent on these activities. Zienkowski is inclined to accept the price of central heating and running water of houses having these facilities to evaluate household production rather than to evaluate the time spent on the activities mentioned above (Zienkowski 1991 p.4). I do not agree: waiting time should be taken into account. The organization of society is one of the data for an economist as is the inefficiency resulting from it.

The eleventh and last problem is the productivity of waiting time until an uncertain event takes place. Waiting for the plumber to show up or for children to come home does not show in time use studies. Waiting time is used either for homework or for recreation, so it is often not counted as productive time in time use research. Yet the waiting time of the fire brigade is paid for and thus considered productive time, even if this waiting time is shortened by playing cards. In the time use studies used in chapter 4 waiting time is not counted in the diaries. I consider it a possible compensation for inefficiency as mentioned before.

I came to the conclusion that serious problems arise as a consequence of different methods, different questions or different classifications of activities. These can be solved if research institutes make (international) agreements. A diary to be used by a sample group during a whole year seems ideal but is expensive. Differences in productivity and economies of scale are also serious problems, so more research is needed.

\subsection{The output method}

The output method as a basis for calculating the value of unpaid work is chosen by only a few authors. Most of these calculations combine the output method with the input method because of a lack of data. Some of the problems encountered by this method will be discussed here.

The first problem is how to measure the physical quantities of goods and services produced in the household. As a rule households do not register their output. Empirical surveys of this output are very few because the number of products and services which can be measured in physical quantities is limited. The number of meals served to a certain number of people is one of the products that can be 
counted. The quality of the meal may differ from a ready-made one course meal served on the kitchen table to a three course meal served on a meticulously laid dinner table with candles and music. Counting cleaning services poses even greater problems: should square meters of vacuum cleaning and dusting be counted or square meters of window cleaning? Looking after children or sick persons can best be measured in the amount of time it takes. This means a return to the input method.

Colin Clark (1958) solves this problem by taking the costs of residents of nurseries, children's homes, old people's homes and other residential homes for adults. He deducted the estimated purchases for goods and services to find the value of household services for children and adults (Clark 1958 p.207-209). A similar method was followed by Chadeau and Fouquet (1981). They took the price of meals and hotels, deducted Value Added Tax, expenses for food etc., interest on medium and long term debts and wages of employees to find the value of household services (Chadeau and Fouquet 1981 p.38/39).

In a later publication Chadeau sugge'sts that it might be possible to extend time use surveys in such a way that data on the nature and volume of household output could also be gathered (Chadeau 1985 p.250-252).

In my view these methods reflect different qualities of goods and services, a different way of life than life at home. Therefore I reject these methods.

Another solution is to combine the output method with the input method for services which cannot be measured in physical quantities (Chadeau and Fouquet 1981; Suviranta 1986; Fitzgerald and Wicks 1990). For products they could not measure in physical quantities Chadeau and Fouquet multiplied hours of time by the wage of a specialized substitute such as a seamstress, a garage mechanic, a nurse etc. (Chadeau and Fouquet 1981 p.39).

Suviranta (1986) split unpaid housework into different components and for each component the value was determined using different methods. The value of child care for example was determined by multiplying the hours of unpaid child care of a time use research by the wages of a municipal home help. The calculated value for the care of children under 7 years of age was estimated to be $5.1 \%$ of GDP. Another volume component was found by subtracting the hours children spent in day care institutions from the theoretical 24-hour-a-day care period. The wages used for this calculation were equal to those of a municipal home help. Calculated value for children under 7 was $5.7 \%$ of GDP. The value of unpaid cooking work was determined using 4 different methods. Values determined in this way ranged from $7.3 \%$ to $13.3 \%$ of GDP. In a similar way the value of home cleaning, laundry, handicrafts etc. was determined. The value of mending and care of clothing, maintenance of heating and water facilities, vehicle repairs, gardening, shopping, repair of dwelling was determined using the time input multiplied by different wages. 
According to the calculations based on the time use study and home help's wages, the value of all unpaid housework was $41.7 \%$ of GDP. If the unpaid work was calculated with yet another measure, namely the help of labour costs included in corresponding market goods and services, for example in meals in restaurants, the value of unpaid housework was about $25 \%$ lower, namely $30 \%$ of GDP (Suviranta 1986). The results of this study seem to imply that producing goods and services on the market is more efficient than producing them at home. I doubt the validity of this conclusion because it is difficult to compare the quality of home made products and market products. Moreover Suviranta made some arbitrary decisions for example about stand-by time.

A different approach is the attempt of Chadeau and Roy (1986) to describe household production functions as a starting point for quantification. They assume an interdependency between household production and household final consumption. They try to match household productive activities and the products households buy as classified in the French National Accounting System and the French Budget Survey. To this end household activities were classified in productive and non-productive activities. A productive activity is any activity which could be carried out with comparable results by any economic unit other than the household according to the French Time Budget Survey (third person criterion). Final consumption commodities are classified according to the role they play in household nonmarket productive processes, and subdivided into three categories: "substitute" products, which save households from producing similar commodities; "complementary" products, which are not produced by households because their production requires advanced technical know-how, but serve to produce other goods and services and "pure final consumption" products, which for the same reasons are not produced by households nor serve any further productive process before being actually consumed. Household activities are then "matched" to products purchased by the household. For example "preparing and cooking food" takes 45 minutes a day, for which substitute products are available; durable goods e.g. a stove are used, as well as intermediate goods e.g. oil, flour etc. Time, durable and intermediate goods are considered "indicators" upon which to build assumptions on modes of household production product by product. Chadeau and Roy distinguish 7 groups of household "services", including services which produce material goods, services which transform goods, services which transform persons etc. The authors remarked that their method shows some degree of abstraction from reality, because the opportunities households have to resort to produce themselves or to buy on the market are different for different groups of households and change in time. No results of this methodological approach have been published as yet.

Fitzgerald and Wicks (1990) split household products into 57 activities. They questioned 480 households in Montana (Missoula) on their household activities in the past week. They categorized these activities in 57 output units including: garbage disposal per bag, vacuuming cleaning per room, snow shoveliling per side/driveway, defrosting per refrigerator etc. For each activity they collected 
information about its frequency, who performed it, the time spent and the amount accomplished. If the respondents thought the time use of this week was "typical" for their normal time use, the researchers multiplied the weekly time use by the number of "typical" weeks in the past six months. For only 3 out of the 57 activities ( $15 \%$ of total household production time) the researchers could think of no other output than hours. The three activities were: care of sick people, care of elderly people and care of children. The value for all household activities was calculated in two ways. The first one the researchers named the "labor value approach": for each activity they found the market wage of a comparable activity. Their second approach, which they named the "direct output approach", was to search for a market price which companies charged for an item as similar as possible to the household output unit mentioned before. To price loads of laundry, they contacted local laundry services. In the case of electrical repairs they took the minimum charges of repair firms. If a firm charged $\$ 40$ to clean an average house and defrosting a refrigerator required ten percent of the total cleaning time, the indicated price for defrosting was $\$ 4$. They concluded that the direct output measure of household production exceeded the "labor value approach" by $44 \%$. I doubt whether the output units in households and firms as defined by Fitzgerald and Wicks are comparable: is it possible to compare defrosting a household refrigerator and defrosting a much bigger professional one? Another objection to Fitzgerald' and Wicks' ideas is the fact that they took the price which a company takes as output. For example it is an arbitrary decision to take the minimum charge of an electrical repair shop as the price for a home made repair.

The second problem is how to value the output if physical quantities are measured. Colin Clark (1958 p.206) takes the minimum costs of the complete care and maintenance of adults and children by local welfare authorities. Chadeau and Fouquet (1981 p.39) takes the average price of a meal and a hotel room. Suviranta (1986) took among others the labour costs of State cafeterias.

Fitzgerald and Wicks (1990) use market prices which firms charged for services as similar as possible to the household output unit. For services which could only be measured in hours of time the problems of evaluation were the same as those met with the input method.

In my view the costs for looking after people in old people's homes or even in jails (Colin Clark), or costs of meals in hotels or state cafeterias are not a good measure, because, as has already been mentioned, they reflect another quality of goods and services.

The third problem is how to account for differences in quality of products and services produced in households and on the market (Lützel 1989 p.344). Lützel puts the question like this: "What is really comparable? For prepared meals for example, is it the fast food prices or those of high class restaurants?" This problem. has not been solved by any of the authors. Can the quality of activities in the household be compared at all with the quality of activities done by a company? 
Life in a hotel room or in an old people's home is a different sort of life and cannot be compared to life in a family. The quality of the same meal taken in a cozy dining room with amiable talk and good music and the same meal taken in the waiting room of a busy railway station is different even if the food were the same. So far no one has been able to solve this problem.

The problem of comparing quality is the fourth problem related to comparing productivity in households and in industry. By definition production processes in industry are based on larger scales. More capital goods and more specialized labour can be used in industry. It can be expected beforehand that productivity will be higher in industry. If a housewife nurses a sick child this will take more time than nursing the same child in a hospital. If a mother looks after one or two children under 4 years of age, this will take more time per child than in a children's day-care centre.

I came to the conclusion that it is not feasible to use the output method, because of lack of data. Anyone using this method at all has to take many arbitrary decisions concerning the measurement of physical output and market prices. Using the input method is more practical.

\subsection{Overview of calculations of the value of unpaid work}

Many calculations of the value of unpaid household work have been made from the beginning of this century. In 1976 Hawrylyshyn made an overview and compared 9 different calculations. He made some adjustments so they could be compared. His conclusion was that the value of household work is about a third of Gross National Product if valued at net market wages (Hawrylyshyn 1976 p.110). Chadeau (1992) published a comparative study of calculations of household work in the United States, France, Canada, Australia, Finland and Norway. She concludes that the contribution of women to housework varies between $2 / 3$ and $3 / 4$ of housework time of men and women combined, that the money value is between 22 and $44 \%$ of GNP if calculated at net average wage rates, between 32 and $60 \%$ if calculated at gross average wage rates and between 39 and $68 \%$ if calculated at gross average wage rates including employer's contribution in social security. Another conclusion is that growth of real disposable income was lower if unpaid housework had been included (see also section 7.2.) (Chadeau 1992).

A very informative and extensive overview was published in 1982 by $\mathrm{L}$. Goldschmidt-Clermont. It contained over 70 calculations. Many of these calculations link unpaid labour to Gross National Product or National Income. I have put these calculations in table 3.1 together with other calculations taken from economic literature. 
Table 3.1.

Estimates of the value of unpaid household work in percentages of GNP or NI

\begin{tabular}{|c|c|c|c|c|}
\hline Period & Author(s) & Country & $\%$ GNP & $\% \mathrm{NI}$ \\
\hline 1909-1919 & Mitchell et al.(1921) & USA & & $25 / 31$ \\
\hline $1929-1932$ & Andrews(1935) & USA & & $28 / 60$ \\
\hline 1930 & Lindahl et al.(1937) & Sweden & & 25 \\
\hline \multirow[t]{2}{*}{ 1924-1936 } & Matolesy and & Hungary & $5.9 /$ & \\
\hline & Varga (1938) & & 12.1 & \\
\hline 1929 & Kuznets (1941) & USA & 25 & \\
\hline $1926-1938$ & Lindberg (1943) & Finland & $20 / 25$ & \\
\hline $1930-1946$ & Statiske Department & Danmark & $14 / 15$ (NNP) & \\
\hline $1940-1945$ & Reid $(1947)^{2}$ & USA & & $20 / 22$ \\
\hline 1956 & Clark (1958) & UK & 42(NNP) & \\
\hline 1956 & Chaput-Auquier & Belgium & $25 / 30$ & \\
\hline 1965 & Morgan et al.(1966) & USA & 38 & \\
\hline $1950-1964$ & Shamseddine(1968 & USA & $24 / 29.5$ & \\
\hline 1960 & Kreps (1971) & USA & 16.7 & \\
\hline 1961 & Lacasse (1961) & Canada & $10 / 16$ & \\
\hline 1929-1965 & Nordhaus\&Tobin(1972) & USA & $42 / 48$ & \\
\hline 1955-1970 & Econ.Council(1973) & Japan & $8 / 11$ & \\
\hline 1973 & Lindgren(1974) & Finland & 16 & \\
\hline 1960-1970 & Weinrobe(1974) & USA & 30 & 40 \\
\hline 1948-1969 & Ruggles\&Ruggles(1975) & USA & $29 / 34$ & \\
\hline 1961-1971 & Adler\&Hawrylyshyn(78) & Canada & $40 / 53$ & \\
\hline $1900-1970$ & Murphy (1978) & USA & $34 / 37.6$ & \\
\hline 1964-1980 & Schettkat(1985) & FRG & $22 / 53$ & \\
\hline 1972 & Brathaug\&Dahle(1991) & Norway & $40 / 53$ & \\
\hline 1975 & Chadeau\&Fouquet(1981)France & $31 / 44$ & 35 & \\
\hline 1976 & Bonke(1991) & Denmark & $34 / 40$ & \\
\hline 1980 & Säntti et al.(1982) & Finland & 42 & \\
\hline 1981 & Brathaug\&Dahle(1991) & Norway & $39 / 41$ & \\
\hline 1981 & OECD(1991) & Canada & $20 / 51$ & \\
\hline 1986 & OECD(1991) & Canada & $17 / 48$ & \\
\hline 1992 & UN (1995) & Australia & 72 & \\
\hline 1992 & UN (1995) & Germany & 53. & \\
\hline 1992 & UN (1.995) & Finland & 45 & \\
\hline
\end{tabular}

Sources: Goldschmidt (1982); Schettkat (1985); OECD (1991); UN (1995).

Table 3.1. shows that calculations differ very much: they range from 5.9 to $53 \%$ of GNP. This is a consequence of the difficulties about different prices (opportunity costs, market wages of a general or specialized substitute, net or gross wages) elaborated upon in chapter 2.5 or different methods, data, prices and activities as elaborated upon in chapters 3.2 and 3.3 .

Another objection against some calculations mentioned before is that the same time use study has been used for the evaluation of different years (Nordhaus and Tobin). 
I cannot draw a general conclusion on the relationship between the value of unpaid household work and GNP or NI. Moreover I doubt whether GNP or NI is a good standard to compare different calculations as will be elaborated upon in chapter 4 .

In some calculations it is not clear which activities have been taken into account. Eisner (1988), for example, reports that Kendrick and he are the only researchers to calculate the value of voluntary labour. In his overview, however, voluntary labour has not been mentioned as a separate item (Eisner 1988 p.1650 and 1670). Kendrick estimates the value of voluntary work at 0.6 to $2 \%$ of GNP in the period 1929-1973.

Many authors use more than one method and more than one price. Often it is not clear which method is used or whether gross or net wages are taken. It is inconsistent to express the value of unpaid work at net wages as a percentage of GNP or GDP. GNP or GDP is the sum of wages inclusive of employer's contribution in social security plus indirect taxes minus subsidies on production plus depreciation plus profits. By definition net wages are used in calculations following the method of opportunity costs, as used by Kreps (1971, as quoted by Goldschmidt 1982); Schettkat (1985); Brathaug (1991); Chadeau (1992); Statistics Canada (1991).

\subsection{Summary and conclusion}

To estimate the value of household work and voluntary activities most authors choose the input method. In the imput method the hours of unpaid work as they emerge from time use studies, are used as volume component. As price component in economic literature one finds net marginal wages (opportunity costs), the market wages of a general or specific substitute for the home producer or average wages of different age groups (see also section 2.5.). Sometimes net wages are taken, sometimes gross wages, sometimes gross wages plus employer's contribution in social security.

The value of calculations of unpaid word reviewed in this chapter varies between $5.9 \%$ and $53 \%$ of Gross National Product. The variation is due to different methods, variations in the people concerned (age and sex), variations in the activities which are counted as procluctive, variations in wages, different countries and periods.

Theoretically the output method is attractive because it resembles the method used in National Accounts. However by using this method it is much more difficult to obtain data. A mixture of different methods is not surveyable and lacks comparability. The attempt of Chadeau and Roy to base an estimation on household production function is theoretically interesting, but technically very difficult to carry out. 
I came to the conclusion that it is best to take the input method and as a price component gross market wages plus employer's contribution in social security of a general substitute, thereby following the method of the National Account as close as possible. Time use surveys are available in many countries. It is a relatively simple and clear method. 


\section{UNPAID WORK IN THE NETHERLANDS 1975-1990}

"What is not counted, is usually not noticed" (Galbraith 1973).

\subsection{Introduction}

In this chapter calculations on the value of unpaid work in the Netherlands in the years 1975, 1980, 1985 and 1990 are presented, based on Intomart time use surveys published by the Social and Cultural Planning Office (Knulst and Van Beek 1990) and micro data of the same surveys of the Steinmetz Archief in Amsterdam.

Section 2 of this chapter gives an overview of time use studies in the Netherlands. Section 3 gives information on the data I used for my calculations of the value of unpaid work. Activities which are considered unpaid work in this study are summed up in section 4 . In section $5 \mathrm{my}$ calculations of the value of unpaid work in the Netherlands as a percentage of GNP turn out to be considerably higher than in other countries. Its reason is being analysed. Furthermore it is argued that in order to compare the value of paid and unpaid work or the value of unpaid work in the course of time, the value of unpaid work could better be expressed as a percentage of the macro wage sum than as a percentage of GNP. In sections 6 to 8 data are presented on the total workload of paid and unpaid work between sexes and per age group and on the division of unpaid work between sexes and per household type. Summary and conclusion are given in section 9 .

\subsection{Time use research in the Netherlands: an overview}

In 1936 the first time use research in the Netherlands was carried out by studying the use of leisure time of 621 Dutch workers (Knulst 1977 p.7). In 1955/1956 and 1962/1963 the Netherlands Central Bureau of Statistics (Statistics Netherlands $\mathrm{SN}$ ) studied the use of leisure time of a representative sample of the Dutch population. From that time until 1970 only a few smaller surveys had been carried out. In 1970 the commercial market research bureau Intomart carried out a time use survey of a representative sample of the Dutch population during a week by order of the Dutch broadcasting corporations. Other organizations, e.g. the Dutch Social and Cultural Planning Office and the University of Wageningen, were also interested in time use studies. Together they participated in an Intomart time use study in 1975, which was carried out based on the list of activities of the cross international time use study as carried out in 1965/1966 by Alexander Szalai (Knulst 1977 p.7). The 1975 study was repeated in 1980, 1985 and 1990.

In the publication of the 1980 time use study of the Dutch Social and Cultural Planning Office special attention was given to unpaid work (Knulst and 
Schoonderwoerd 1983). Comparison of the 1975 and 1980 studies shows that time and energy had shifted from paid to unpaid activities. Unpaid work was defined as activities in the household, caring for members of the family, do-it-yourself activities and voluntary work. Household work, do-it-yourself activities and voluntary work all shared in the increase. The main increase was to be ascribed to among others married people aged 35-65 years. In 1980 unpaid work took nearly twice as many hours of time than paid work. In 1980 paid and unpaid work was quite unevenly divided between men and women. Of all the work performed by men an average of $36 \%$ was unpaid work, for women $84 \%$ of working hours was unpaid. Between 1975 and 1980 particularly fathers in young families considerably increased their share in household and family work. Married women with young children spent most of their time in the household. The amount of household work performed by men is positively rather than negatively related to the number of hours spent on it by women. For instance, in households where neither of the partners have jobs, the man performs on average more household work than in households where the wife has a job. The rules of the paid labour system and education time tables do not only tie the time use of paid workers and schoolgoers but also of the rest of the family. For instance the planning of household activities of housewives is visibly influenced by the times of leaving and home-coming of working or schoolgoing members of the family. Voluntary work took $5 \%$ of all working hours in 1985 (Knulst and Schoonderwoerd 1983).

In 1987 Statistics Netherlands started a new survey on the time use considering all activities of the Dutch population of 12 years and older among a sample of nearly 7000 persons. A publication of Stoop and Oudhof (1989) forms part of this study. Stoop and Oudhof compare the time use of men and women, united in 1684 couples, married or cohabitating. In this study women's share in unpaid work depends upon the composition of the household, women's labour market participation and opinions of both partners about sharing unpaid work. The younger the youngest child, the larger the share of women in household work; the more she participates in the labour market, the smaller her share in household work; the stronger her opinion about sharing household work with her husband, the smaller her share in household work (Stoop and Oudhof 1989 p.11-13).

Time use research by Van der Lippe (1993) shows that the division of unpaid work between man and wife (married or cohabitating), unemployed, disabled and retired people excluded, depends on the presence and number of (young) children, the wage of the woman and the attitudes of the social environment (Van der Lippe 1993 p.59 and 141).

Droogleever Fortuyn (1993) studied the household arrangements of 70 two-earner families. The division of unpaid work depended on the position of the husband and wife on the labour market, the age of the youngest child, the educational level of both partners and their attitude towards sharing; paid and unpaid work (Droogleever Fortuyn 1993 p.291-294). 
In 1994 Van der Lippe and Niphuis-Nell of the Social and Cultural Planning Office published a Workdocument on the development of the division of unpaid labour between men and women in the period 1975-1990 based on the Intomart time use data. For women in all age groups time for household tasks decreased and it increased for men. Especially married women with a paid job of 30 hours or more a week decreased their unpaid workload by 15 hours a week, whereas their husbands increased their unpaid working week by 2.25 hours a week. This was the only category in which unpaid work was almost evenly divided: women took care of $52 \%$ of all household tasks and childcare in 1990 (Van der Lippe and Niphuis-Nell 1994).

\subsection{The data for this study}

The time use data used in this chapter were collected by a commercial market research bureau Intomart, on instruction of the Dutch Broadcasting Corporations, the Social and Cultural Planning Office and other organizations which participated in the time use surveys. Intomart gathered data in 1975, 1980, 1985 and 1990 following the same method, so the data of these years could be compared. The number of respondents was enlarged from 1309 in 1975 to 3150 in 1990 to make analyses of subpopulations possible. The same questions were asked and the same codes used for all activities in the years 1975-1990. Respondents were asked to write down in a precoded diary their time use for every fifteen minutes or more they spent on an activity during a whole week in autumn. They were interviewed about all members of the household before and after recording their time use in the diary. Because of non-response and over-representation of small households the data were weighted according to number of people, sex, age and urbanity. The Social and Cultural Planning Office published the macro data of the 1975, 1980 and 1985 time use studies in a publication of 1990 (Knulst and Van Beek 1990 pp.138-159). I have chosen these macro data as the basis for my calculations in section 4.5-4.7, supplemented by the 1990 micro data of the Steinmetz Archief. The micro data of the 1985 and 1990 time use studies, which I used for section 4.8. of this chapter and for the income distribution of chapter 6, I also thankfully received from the Steinmetz Archief in Amsterdam.

Using these data several problems as mentioned in section 3.2. did not crop up: a standardized method was used; the question who had to be counted was irrelevant because a representative sample was taken; the problem of joint or multiple activities was solved by taking down in the diary only the primary activity. However, the difference in time use between working days and Sundays and holidays and the seasonal and cyclical variations in time use could not be distinguished in the data, because the observations took place during one week in autumn. The data did not allow to observe possible scale economies, differences in productivity or waiting time. These disadvantages could have been avoided if the calculation of the value of unpaid work had been the target of the time use studies. As it is, I consider myself a privileged person to have been allowed to use the existing data. 
The different types of unpaid work discussed in the next section.

\subsection{Types of unpaid work}

Household work, e.g. cooking, cleaning, washing and ironing, daily purchases, mending clothes house repairs, is considered unpaid work by most researchers (Hawrylyshyn 1976; Juster 1985 p.330; Gershuny and Robinson 1988; Schäfer 1992). Child care is also considered unpaid work, but some researchers see care of other members of the family as non-productive personal care (Juster 1985 p.330).

Do-it-yourself activities, e.g. house repairs, are generally thought of as productive unpaid work (Hawrylyshyn 1976; Juster 1985; Gershuny and Robinson 1988), but not all researchers consider knitting and sewing, or gardening productive activities (Juster 1985 p.331). Floro argues that there is often an intertwining of social activities with work. For instance when clothes are mended while talking with friends, is it "work" or "leisure"? The leisure component may disappear when the work activity pace quickens for some or other reason (Floro 1995 p.1919). Opinions differ on voluntary activities for church, unions, political and other organizations. Especially because voluntary work differs from the other three categories of unpaid work, as these are not performed and consumed in the own household. Hawrylyshyn thinks that voluntary activities for social organizations were productive, Juster considers them to be leisure activities (Hawrylyshyn 1977 p.80; Juster 1985 p.331). Others (Blau and Ferber 1986; Schäfer 1992) thinks that these activities were unpaid work. Blau and Ferber defines voluntary work as activities which form part of an organized programme, do not give direct material reward whereas the chief beneficiaries must not be members of the family (Blau and Ferber 1986 p.130).

In a study on Informal Care, published in 1994, the Social and Cultural Planning Office made a distinction between informal care and voluntary work. Informal care is given voluntarily, unpaid and unorganized to old and sick people who can no longer take care of their household tasks or personal care. Voluntary work is also unpaid, but forms part of an organization or institution outside the social network of the recipient. Although not explicitly mentioned, these definitions imply that the third person criterion is valid, because a hospital or an old people's home, where they (or the social security) have to pay for formal care, is the alternative for informal care to these sick and oid people. The same applies to the activities of volunteers (De Boer et al 1994 p.28).

A subjective approach to define household work is followed by Homan (1988). In an interview he asked respondents: "How many hours do you and your partner spend on household work per week?" (Homan 1988 p.77). My objection to this subjective definition is that the same activities are sometimes classified as productive, sometimes as non-productive, depending on the respondent. This method is not suitable to extend the production boundary.

In the eyes of the Dutch Social and Cultural Planning Office (1983) a clear-cut 
definition of unpaid work could not be given, it is arbitrary. Activities, e.g. cooking, gardening, child care, taking minutes and cycle racing are done as a profession and as a hobby, but some can also be considered unpaid work. Consequently the borders between professional work, unpaid work and leisure are not sharp. Scientific literature offers no clear-cut criteria or definitions. The classification of activities as unpaid work is an arbitrary arrangement or to use the words of economist Jan Pen in a reaction to my first articie on unpaid work: "Cooking is work. Making tea also. Is pouring tea work or stirring to dissolve the sugar? Or bringing the teacup to one's mouth"? If these questions are answered with yes, only drinking tea remains as consumption" (Pen 1970 p.592) (Knulst and Schoonderwoerdi 1983 p.53-56).

I followed the 1983 classification of the Social and Cultural Planning Office for two reasons. Using the data of SCP implies the acceptance of their classification of activities. The other reason is that I consider the SCP-classification realistic, except from time spent on shopping, which the Office did not consider unpaid work then(11). So I added time for shopping to unpaid work. As mentioned before, the activities in these Dutch time use studies are categorized with Szalai's classification as a starting point (Knulst and van Beek 1990 p.127). In the publication of the Social and Cultural Planning Office of the 1980 time use study, the activities were classified in 5 subgroups: work, household work, personal care, education and leisure activities (Knulst and Schoonderwoerd 1983 p.268/269). The data have been subdivided into 5 age groups: 12-24, 25-34, 35-49, 50-64 and 65 years and over.

In these Dutch studies paid working hours are working hours for which one receives wages, a salary or other renumeration. Time spent in transit to and from work is considered working hours. The same applies to study or leisure during working hours.

In my calculations the following categories of the Social and Cultural Planning Office are considered unpaid work (Knulst and van Beek 1990 p.138-159):

Household work:

preparing meals, cleaning dishes, cleaning, dusting, scrubbing, waxing, making beds, changing sheets, jobs outside, laundry, ironing, organizing and transport (numbers 100,110, 121, 122, 123, 124, 125, 130, 141, 142, 180, 191, 194, 195 and 350);

Care of family:

care of baby and other children, help with schoolwork, reading, playing, walking with children, medical care of children, care of other members of the family (numbers 200, 210, 220, 230, 240, 250, 260, 270, 291- 295 and 420)

Shopping:

daily needs in supermarket or market, shopping in department store, shopping for clothes and shoes, shopping in do-it-yourself stores, shopping for household articles and furniture, shopping for other articles, post-office,

11Van der Lippe and Niphuis-Nell also added shopping to unpaid work in the 1994 SCP publication 
bank, services, transport, waiting (numbers $301,302,310,311,312,313,314,315$, $316,340,351,360,370,391,392,394,395)$;

Do-it-yourself activities:

do-it-yourself jobs, knitting, embroidery, taking care of garden and plants, care of pets (numbers 151, 160, 171, 172, 840);

Voluntary work:

managing political and social organizations, voluntary activities, family help, transport (numbers 600, 610, 620, 630, 640, 660, 670, 691-695).

Although there are borderline cases, the difference between unpaid labour on the one hand and leisure and personal care on the other hand can be shown by looking at the third person criterion. If a healthy, adult individual is in principle able to do activities himself and normally cannot hire a third person for these activities, these activities are either a biological need or a leisure activity, if one considers time spent on education a leisure activity. If he can delegate the activity to a third person hired on the labour market or substitute the activity by market goods the activity is considered unpaid work. Personal care, education and leisure activities are not considered unpaid work.

Activities of children of 12 years and over, of people of 65 years and over and of unemployed people have also been counted. The question whether activities of these groups have any money value is dealt with in chapter 2 section 5 . As it can be doubted whether the productivity of children and older people is the same as the productivity of people 25-64 years of age, the value of unpaid work of the population of 25-64 of age is presented separately as well as included in the value of unpaid work of the whole population of 12 years and over.

\subsection{Empirical estimations of the value of unpaid work in the Netherlands 1975-1990}

Earlier estimations of the value of unpaid work (Bruyn-Hundt 1970; 1983) were based on the small-scale time use studies of the University of Wageningen, NIPO and the time use studies of Knulst (1977) and Knulst and Schoonderwoerd (1983). The calculations published in 1970 were based on volume components which cannot be compared with the time use studies available now. The calculations published in 1983 were based on the 1975 and 1980 Intomart time use studies published by the Social and Cultural Planning Office in 1977 and 1983 (Knulst 1977; Knulst and Schoonderwoerd 1983). I decided to repeat the calculations for the years 1975 and 1980 for several reasons. The first reason is that in 1990 the Social and Cultural Planning Office published for the first time data which compared the results of three time use studies (1975, 1980 and 1985) and showed them simultaneously (Knulst and Van Beek 1990). The second reason is that in the 1990 publication of the Social and Cultural Planning Office slight changes were made in the subdivision of activities. The third reason is that the taxation and social security systems have changed since 1983, which obliged me to make small changes in the calculations of the gross plus wages. 
In chapter three I argue that the best method to evaluate unpaid work is the input method using as a price component gross wages plus employer's contribution in social security. The volume component consists of minutes per week of the four time use studies mentioned earlier for every activity for the age groups: 12-24, 25-34, 35-49, 50-64 and 64 and over subdivided between sexes. I multiplied these minutes with the number of persons in every age group and divided the result by 60 (minutes) to obtain working hours per week. A correction was made for standard weekly working hours because standard working hours changed between 1975 and 1990. After that the week volume was multiplied by one of the price components mentioned below.

The price components used in the calculations are:

1. The legal minimum wages per week for adults plus employer's contribution in social security. In years in which the minimum wages changed during the year the weighted average was used.

2. The weekly wages of a home help (gezinsverzorgster), a professional help in the household employed by specialized organizations for household help subsidized by the authorities. I took the wages of a home help in scale 12 of the existing 17 scales of the collective wage agreement (Collectieve Arbeidsovereenkomst - CAO) on 1st January. A scale 12 home help is supposed to be an independent substitute for the housewife. Gross wages plus employer's contribution in social security have been used.

3. The average gross wages per week of employees in the age of 16-64 years working full-time, exclusive overtime work, plus employer's contribution in social security (Source: $\mathrm{SN}$ ).

In table 4.1. the development of the volume of unpaid work is compared with the volume of paid work, calculations of the value of unpaid work are presented as a percentage of Gross National Product and as a percentage of the Macro Wage sum. The left side of the table concerns the whole Dutch population of 12 years and older and the right side concerns the population of 25-64 years of age. The volume of unpaid work and paid work is the result of the participation rate and of the time each respondent spent on unpaid and paid work.

The left half of the first part of table 4.1. shows that the number of hours of unpaid work per year is between 1.5 and 1.9 times higher than paid work for the whole population of 12 years and over. The right half of table 4.1. shows that even in the active age groups 25-64 the average volume of unpaid work is higher than the average volume of paid work, although it is lower than the volume of unpaid work for the whole population. The main reason is that the participation rate of younger and older people in unpaid work is much higher than the participation rate in paid work. Unpaid work for all age groups is high because unpaid work is not tied to a working timetable, whereas the stress to obtain a high productivity is lower doing unpaid work (Knulst and Schoonderwoerd 1983 p.57). 
Table 4.1. (lefthand side)

Unpaid work as a percentage of paid work, GNP and Macro Wage Sum

\begin{tabular}{lrrrr}
\hline Population of 12 years of age and over & 1975 & 1980 & 1985 & 1990 \\
\hline & & & & \\
Average paid work in hours per week: & 23.8 & 22.1 & 21.6 & 24.4 \\
- men & 6.1 & 6.2 & 6.8 & 8.8 \\
- women & 14.8 & 14.0 & 14.1 & 16.5 \\
- all & 15.0 & 16.1 & 17.3 & 16.5 \\
Average unpaid work hours per week: & 36.2 & 37.4 & 36.7 & 33.1 \\
- men & 25.7 & 26.9 & 27.2 & 24.9 \\
- women & $(174 \%)$ & $(192 \%)$ & $(193 \%)$ & $(151 \%)$ \\
- all & & & & \\
as \% of paid work & 219 & 336 & 418 & 509 \\
\hline & 147 & 227 & 266 & 259 \\
GNP (in bn. Dfl.) & $(67)$ & $(68)$ & $(64)$ & $(51)$ \\
Unpaid work (in bn. Dfl.) & 181 & 263 & 318 & 321 \\
valued at minimum wages: & $(82)$ & $(78)$ & $(76)$ & $(63)$ \\
- as \% of GNP & 237 & 336 & 419 & 467 \\
- in bn. Dfl. at wages home help & $(108)$ & $(109)$ & $(110)$ & $(91)$ \\
- as \% of GNP & & & & \\
- in bn. Dfl. at average earned wages & 131 & 198 & 217 & 260 \\
- as \% of GNP: & & & & \\
\hline Macro wage sum (in bn. Dfl.) & 112 & 115 & 123 & 100 \\
Unpaid work as \% of macro wages sum \\
valued at:
\end{tabular}

The left half of the first part of table 4.1. also shows that the volume of paid work decreased in the period 1975-1985 and increased again in 1985-1990 for all men aged 12 years and over. For all women aged 12 years and over paid work increased over the whole period. The number of hours of unpaid work increased for all men and until 1985 it also slightly increased for women. These increases and decreases led to a growth of unpaid work and a decrease of paid work until 1985. After 1985 the reverse was true: unpaid work decreased whereas paid work increased. Over the entire period paid work increased and unpaid work decreased. To all probability the main reason of these developments was the rising rate of unemployment, which reached a peak in 1984. After 1984 unemployment decreased (see also section 5.5.4.). The decreasing participation of men in paid work until 1985 led to an increase in their unpaid working hours. It is remarkable that the increasing participation of women in paid work did not diminish their hours of unpaid work until after 1985. 
Table 4.1. (righthand side)

Unpaid work as a percentage of paid work, GNP and Macro Wage Sum

Population 25-64 years of age

1975

1980

1985

1990

Average paid work in hours per week:

-men

-women

$(1975$

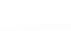

1985

1990

- all

Average unpaid work hours per week:

- men
-women
-all

- as $\%$ of paid work.

$\begin{array}{rrrr}32.4 & 30.3 & 29.7 & 32.6 \\ 5.0 & 5.6 & 7.5 & 9.4 \\ 18.7 & 18.1 & 18.7 & 20.7\end{array}$

GNP (in bn. Dfl.)

Unpaid work (in bn. Df.)

valued at minimum wages:

- as \% of GNP:

- in bn. Dfl. at wages home help:

- as \% of GNP

- in bn. Dfl. at average earned wages

- as \% of GNP:

\section{0}

44.4

30.1

(161\%)

17.7
45.6
31.5
$(174 \%)$

\begin{tabular}{rrrr}
219 & 336 & 418 & 509 \\
100 & 156 & 189 & 184 \\
$(46)$ & $(46)$ & $(45)$ & $(36)$ \\
124 & 181 & 226 & 227 \\
$(56)$ & $(54)$ & $(54)$ & $(45)$ \\
162 & 251 & 327 & 297 \\
$(74)$ & $(75)$ & $(78)$ & $(58)$ \\
\hline 131 & 198 & 217 & 260 \\
& & & \\
77 & 79 & 87 & 71 \\
94 & 91 & 104 & 87 \\
124 & 127 & 151 & 114
\end{tabular}

Macro wage sum (in bn. Dfl.)

Unpaid work as \% of macro wage sum

valued at:

- minimum wages

- wages home help

- average eamed wages

124

17.7

45.6

31.5

$74 \%)$

18.

18.1
44.9

17.5

39.8

28.6

(138\%)

(168\%)

9.4

0.7 
between 45 and $56 \%$ respectively. Calculated at average earned wages these percentages are much higher: between 91 and $110 \%$ and between 58 and $78 \%$ respectively. When comparing the volume of unpaid work in relation to paid work (first part of table 4.1.) to the value of unpaid work in relation to GNP (second part of table 4.1.), it is remarkable to see the low percentages of value compared to the much higher percentages of volume. One might expect the value of unpaid labour to be higher than GNP. This is not true as is shown in the second part of table 4.1. Although the number of unpaid hours of the active population is about 38 to $74 \%$ higher than the number of paid hours, the value of unpaid work does not even equal GNP.

There are reasons why the value of unpaid work is less than GNP:

1. GNP is the sum of wages, other income, indirect taxes, depreciation and net income from abroad minus price subsidies. Paid work (sum of wages) forms a fluctuating part of GNP of about 55 to $65 \%$ (SN 1986 p.274).

2. Unpaid work is calculated at minimum or low wages, because unpaid work is supposed to have a low professional knowledge and a low productivity.

The percentages in table 4.1. are much higher than in calculations mentioned in economic literature (see section 3.4.). The higher values of unpaid work in the Netherlands can be ascribed to three causes:

1. Labour market participation of Dutch women was low until 1985 compared to other EC-countries (OECD 1988 p.200). Dutch women are leaders in working part-time in the OECD (OECD 1988 p.149; OECD 1990 p.200).

2. In the calculations of the left half of table 4.1. unpaid labour of children and elderly people was taken into account; in other calculations only unpaid labour of adults or unpaid work of people in active age groups was taken into account.

3. In table 4.1. gross wages inclusive of employer's contribution in social security were used. In most calculations in section 3.4 net wages have been used. In the Netherlands the gap between net wages and gross wages is considerable. If net wages are $100 \%$, gross wages plus employer's contribution in social security are 180 to $195 \%$ of net wages, in other words gross plus wages are nearly twice as high as net wages. This implies that if the value of unpaid work in table 4.1. is corrected for net wages, the percentages of the value of unpaid work for the active population range from about 18 to $39 \%$. These percentages are more in accordance with the percentages found by others (see section 3.4).

Looking at the value of unpaid work as a percentage of GNP in the calculations of table 4.1., one has the impression that the value of unpaid work has diminished during the whole period, if the minimum wages or the wages of a home help are used as a price component. If average earned wages are used, unpaid work increased very slightly until 1985 and decreased after 1985. In contrast to the development of unpaid work calculated at minimum wages or the wages of a home help, the first part of table 4.1. shows that the volume of unpaid work increased significantly until 1985, to decrease sharply afterwards. This leads to the 
question whether expressing the value of unpaid work as a percentage of GNP is a useful method to measure the development of paid and unpaid work in relation to each other or to compare the development of unpaid work in time. As mentioned before GNP is the sum of wages, other income, indirect taxes, depreciation and net income from abroad minus price subsidies. If for example other incomes change because of profits, or because indirect taxes, income from abroad or depreciations change, the value of unpaid work as a percentage of GNP changes too. If the value of unpaid work is related to GNP it does not tell much about the development of unpaid work in relation to paid work. Yet most researchers use GNP as a measuring instrument. Some used Net National Income (NNI) or Net National Product (NINP) (Mitchell 1921; Andrews 1935; Lindahl 1930; Statistike Department of Denmark 1948, as quoted by Goldschmidt 1982; Clark 1956) or used both GNP and NNP (Weinrobe 1974; Chadeau 1985) or used Gross Internal Product (GIP) (Chadeau \& Fouquet 1981). The difference between GNP and NNP is that NNP does not count indirect taxes, depreciation and price subsidies. The difference between GNP and GIP is that GIP does not count income from abroad. In my opinion the macro wage sum inclusive of employer's contribution in social security is a better measure to compare the value of unpaid labour at different points of time or between different countries than GNP, NNP or GIP. Therefore in the last part of table 4.1. the value of unpaid work is related to the macro wage sum. The sum of wages in this table is the sum of gross wages paid by trade and government inclusive of the employer's contribution in social security as shown in National Accounts. One would expect unpaid work as a percentage of paid work, to be identical to unpaid work at average earned wages as a percentage of the macro wage sum. However, there are statistical differences due to the fact that the macro wage sum comes from the National Accounts and average earned wages from a monthly SN publication, based on the wages of full-time employees. So average earned wages is not the average of the macro wage sum.

If the value of unpaid work is related to the macro wage sum, more insight is obtained in the relation between the value of paid and unpaid work and the development of the value of unpaid labour. The left side of the lower part of table 4.1. shows that the value of unpaid work of the entire population of 12 years and older is higher than the sum of wages. This is also true for half of the calculations of the value of unpaid labour of the population 25-64 years of age, if calculated at average earned wages or the wages of a home help as is shown on the right side of the lower part of table 4.1 .

\subsection{Total workload per age group and between sexes}

Data on the division of the total workload of paid and unpaid work over the lifecycle and between sexes are presented in this section. The data used in this section offer the opportunity to look at the division of paid and unpaid work at nacro level.

Table 4.2. shows that paid work is done mainly by men and unpaid work by 
women as is the case in most European countries (Council of Europe 1994 p.15-20). From 1975 to 1985 men's paid hours decreased, with the exception of men aged 35-49 years. In 1990 men's paid hours increased in all age groups except in the one of 50 years and over. Women's paid hours increased over the whole period in all age groups except the youngest one.

Men's unpaid working hours increased until 1985, except for the youngest age group. In 1990 unpaid hours decreased for men of all age groups except for the group over 50. The number of women's unpaid hours increased slightly until 1985, after which a sharp decline is seen, except for older women. Consequently 1990 is an important year: paid work of men and women increased, unpaid work decreased for men and women. The same developments of more equality between men and women in sharing paid and unpaid work can be seen in other European countries (Council of Europe 1994). Men's increase in unpaid hours only compensates for half of women's decrease in unpaid hours.

Table 4.2. shows that women are working longer hours than men, if paid and unpaid hours are taken together. This applies to all age groups, except for the age group 35-49 in the years 1985 and 1990. There is a tendency for differences in workload to become smaller in the course of time. According to the Council of Europe (1994 p.21) this tendency should be ascribed to the growing labour market participation of women. Sharing the total work load seems to be most equal in countries with a high proportion of women in the labour force.

In 1975 women's workload counted 3 hours per week more than men's, in 1990 the difference had diminished to 1 hour a week. In 1975 the difference in workload between men and women was most pronounced for the youngest and oldest age groups: young and old women worked 7 hours more a week than men of the sarne age. In 1990 this gap was still rather large for men and women over 50: older women worked 3 to 5 hours a week more than older men.

Furthermore table 4.2. shows that on average people spend 38 to 44 hours a week on work. But behind this average an interesting development emerges: the workload of younger and older people is not as high and decreased in the period 1975-1990. The workload of people between 25-50 exceeds 50 hours a week. It even increased for the age group 35-49 in the period 1975-1990, especially for men. The workload of the age group over 50 is much lower and diminishes with age. The Dutch Social and Cultural Planning Office also found that the workload becomes less heavy with age and concluded "leisure comes with age" (Knulst and Van Beek 1990 p.117). 
Table 4.2.

Average workload (paid + unpaid) of men and women of 12 years and older in hours per week

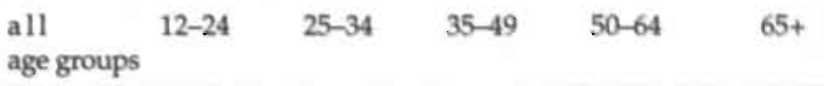

1975

\begin{tabular}{|c|c|c|c|c|c|c|c|}
\hline Men: & paid & 24 & 15 & 36 & 32 & 28 & 3 \\
\hline & unpaid & 15 & 9 & 16 & 17 & 15 & 26 \\
\hline & total workload & 39 & 24 & 52 & 49 & 43 & 29 \\
\hline Women: & paid & 6 & 12 & 7 & 5 & 2.5 & ( \\
\hline & unpaid & 36 & 19 & 45 & 45 & 43 & 36 \\
\hline & total workload & 42 & 31 & 52 & 50 & 45.5 & 36 \\
\hline
\end{tabular}

1980

\begin{tabular}{|c|c|c|c|c|c|c|c|}
\hline Men: & paid & 22 & 13 & 33 & 33 & 23 & 1 \\
\hline & unpaid & 16 & 9 & 17 & 17 & 19 & 23 \\
\hline & total workload & 38 & 22 & 50 & 50 & 42 & 24 \\
\hline Women: & paid & 6 & 11 & 8 & 6 & 2.5 & 0 \\
\hline & unpaid & 37 & 17 & 47 & 47 & 44 & 40 \\
\hline & total workload & 43 & 28 & 55 & 53 & 46.5 & 40 \\
\hline 1985 & & & & & & & \\
\hline Men: & paid & 22 & 12 & 32 & 35 & 20 & 1. \\
\hline & unpaid & 17 & 9 & 18 & 19 & 22 & 25 \\
\hline & total workload & 39 & 21 & 50 & 54 & 42 & 26.5 \\
\hline Women: & paid & 7 & 9 & 12 & 7 & 4 & 0 \\
\hline & unpaid & 37 & 16 & 43 & $47^{\prime}$ & 44 & 37.5 \\
\hline & total workload & 44 & 25 & 55 & 54 & 48 & 37.5 \\
\hline
\end{tabular}

1990

\begin{tabular}{|c|c|c|c|c|c|c|c|}
\hline \multirow[t]{3}{*}{ Men: } & paid & 24 & 16 & 36 & 38 & 19 & 1 \\
\hline & unpaid & 17 & 8 & 15 & 16 & 22 & 29 \\
\hline & total workload & 41 & 24 & 51 & 54 & 41 & 30 \\
\hline \multirow[t]{3}{*}{ Women: } & paid & 9 & 12 & 13 & 10 & 5 & 0 \\
\hline & unpaid & 33 & 14 & 38 & 41 & 39 & 35 \\
\hline & total workload & 42 & 26 & 51 & 51 & 44 & 35 \\
\hline
\end{tabular}

Source: Own calculations based on time studies of SCP 1990 and Steinmetz Archief 1990

Conclusions: A first conclusion is that, although the difference is narrowing, paid work is still mainly done by men, unpaid work by women. A second conclusion is that unpaid work has decreased for women and has increased for men. A third 
conclusion is that paid and unpaid working hours are in competition. If paid work decreases, unpaid work increases and vice versa, but the rate of substitution is not 1:1. A fourth conclusion is that, although in all female age groups the total workload in hours of paid plus unpaid work is higher than in all male age groups, the differences between men and women in all age groups are narrowing. In the next section the distribution of all unpaid activities will be analysed, as well as men's share in paid and unpaid work.

\subsection{The division of paid and unpaid work between sexes}

The data in table 4.3. about paid as well as unpaid work come from the SCP-time use studies. It shows that women's share in paid work is about $25 \%$ and in unpaid work it is about $70 \%$. Women's share in paid work in the age group 25-64 is even less than their share in the population of 12 years and over. The reason of this smaller share probably lies in the high labour market participation of women under 25 , compared to older women.

Table 4.3.

Women's share in paid and unpaid work for the population of 12 years and over (population 25-64 years)

\begin{tabular}{lllll}
\hline & \multicolumn{2}{l}{ Paid work } & \multicolumn{2}{l}{ Unpaid work } \\
\hline 1975 & $21 \%$ & $(13 \%)$ & $71 \%$ & $(73 \%)$ \\
1980 & $22 \%$ & $(15 \%)$ & $70 \%$ & $(72 \%)$ \\
1985 & $24 \%$ & $(20 \%)$ & $69 \%$ & $(69 \%)$ \\
1990 & $27 \%$ & $(22 \%)$ & $67 \%$ & $(78 \%)$ \\
\hline
\end{tabular}

Women's share in paid work considering the population of 12 years and over, has increased during the whole period, this also applies to the age group 25-64 years. Women's share in unpaid word considering the age group 25-64 has decreased until the year 1985, but in 1990 it is even higher than in 1975. Overlooking the whole period women's share in unpaid work has decreased for the population of 12 years and over.

To analyse why and how the division of paid and unpaid work between men and women has changed, the distribution of unpaid work over different unpaid activities will be shown in table 4.4.

Household work consumes about nearly half of all unpaid time. Its share declined a little bit in the period 1975-1990. Improved household technology can explain the decreasing share of Household work. The share of Care of family did not change much, nor did the share of Shopping. 
Table 4.4.

Share of different activities in unpaid work

\begin{tabular}{|c|c|c|c|c|c|c|c|c|}
\hline \multirow[b]{2}{*}{ Activity } & \multicolumn{2}{|r|}{1975} & \multicolumn{2}{|r|}{1980} & \multicolumn{2}{|r|}{1985} & \multicolumn{2}{|r|}{1990} \\
\hline & Abs. & $\%$ & Abs. & $\%$ & Abs. & $\%$ & Abs. & $\%$ \\
\hline Household work & 12 & 47 & 13 & 47 & 12 & 46 & 11 & 45 \\
\hline Care of family & 3 & 11 & 3 & 11 & 3 & 10 & 3 & 12 \\
\hline Shopping & 4 & 16 & 4 & 15 & 4 & 16 & 4 & 16 \\
\hline Do-it-yourself & 5 & 18 & 5 & 20 & 6 & 21 & 5 & 18 \\
\hline \multirow[t]{2}{*}{ Voluntary work } & 2 & 7 & 2 & 7 & 2 & 8 & 2 & 9 \\
\hline & 26 & 100 & 27 & 100 & 27 & 100 & 25 & 100 \\
\hline
\end{tabular}

Source: Own calculations based on Knulst and. Van Beek 1990.

Table 4.4. shows that the share of Do-it-yourself activities rose until 1985 and declined in 1990. The high rate of unemployment with a peak in 1984 and the rising costs of services may be explanations for this development. Voluntary work consumed more time in 1990 compared to 1975. Less hours of paid work of older men could explain the growing share of Voluntary work but this turned out not to be true because men's share in Voluntary work has decreased as shown in table 4.5. Another explanation for the growing share of Voluntary work is the cuts in government spending for paid care and hospitalization and the growing number of senior citizens.

In sections 5 and 6 it was shown that men performed more unpaid work in 1990 compared to 1975 and women more paid work. However, men's share in unpaid work increased less than women's share in paid work. Men's share in unpaid work increased about $1 \%$ per year, whereas women's share in paid work increased about $2 \%$ per year, considering the whole population of 12 years and over. If the population of 25-64 years is considered over a period of 15 years, men's share in unpaid work increased by $19 \%$, whereas women's share in paid work increased by $77 \%$ (from 13 to $23 \%$ ) as is shown in table 4.5 .

What type of unpaid activities performed by men are responsible for their rising share in unpaid work? To analyse whether men in the active period of their lives do more or less than all men aged 12 years and over, men's share in the population of $25-64$ years has been put in brackets. 
Table 4.5.

Men's share in paid and unpaid work as percentage of all paid and unpaid work of the male and female population aged 12 years and over (population 25-64)

\begin{tabular}{|c|c|c|c|c|c|c|c|c|}
\hline \multirow[b]{2}{*}{ Paid work } & \multicolumn{2}{|c|}{1975} & \multicolumn{2}{|c|}{1980} & \multicolumn{2}{|c|}{1985} & \multicolumn{2}{|c|}{1990} \\
\hline & 79 & (87) & 78 & (84) & 75 & $(80)$ & 73 & (77) \\
\hline \multicolumn{9}{|l|}{ Unpaid work: } \\
\hline - household work & 17 & (14) & 19 & (16) & 23 & (21) & 24 & (21) \\
\hline - care of family & 28 & (26) & 26 & (27) & 25 & (26) & 26 & (26) \\
\hline -shopping & 34 & (33) & 36 & (34) & 36 & (36) & 38 & (35) \\
\hline - do-it-yourself & 46 & $(45)$ & 43 & (44) & 41 & (42) & 47 & (47) \\
\hline - voluntary work & 54 & $(54)$ & 54 & $(5 ; 2)$ & 53 & (52) & 53 & (51) \\
\hline Overall unpaid & 29 & (26) & 30 & $(28)$ & 31 & (30) & 33 & (31) \\
\hline
\end{tabular}

Source: Own calculations based on Knulst and Van Beek 1990.

Table 4.5 shows that men take care of about one fifth of Household work. They increased their share in this activity. The share of all men is higher than the share of men in the age group of 25-64. This is clearly due to the traditional division of paid work between men and women. All men take care of about one quarter of Care of family. There is no marked development in their share over the years, nor can a marked difference between all men and men in the age group $25-64$ be distinguished. Shopping is men's work for about one third. Men have a growing share in this activity. It applies to working as well as nonworking men. It is remarkable to see men's decreasing share in Do-it-yourself activities until 1985. One would have expected them to increase their share in these activities in a period of high unemployment. Their share in Do-it-yourself activities rose again in 1990 notwithstanding their growing hours of paid work. The division of Voluntary work between sexes did not change much over the whole period.

An explanation for men's rising share in unpaid work has been given by Pott-Buter (1993 p.320). According to Pott-Buter home care and child care used to be luxury goods. Rising wages of husbands made it possible for wives to stay at home before World War II. Improved household technology and reduced family size decreased the demand for home care after World War II. This decrease has been stronger than the increase of rising income levels. So the substitution effect of women's own wages has come to dominate the income effect of men's wages. Married women have a greater preference to combine market work with caring for home and children.

Employment opportunities obviously influence the amount of unpaid work for men as well as for women. Paid hours for men in the age groups 12-50 years rose. after 1985 (see table 4.2.) That is probably the reason that their share in Shopping and Voluntary work decreased in 1990. 


\subsection{Unpaid work per household type}

In the 1985 and 1990 time use surveys several questions were asked which made it possible to categorize households in one and two-earner households, one-parent households and single people. One-earner households are households where only one of the partners, male or female, is the breadwinner. In two-earner households both partners are in the labour market, although the division of paid work is not equal in most cases. Therefore a distinction is made between the main and the second breadwinner. The subgroup "other members of the family" are children or parents of the head of the family or other members of the family within the sarne household. Because some subgroups were very limited in number the 1985 and 1990 data were put together. Even after adding the 1985 and 1990 data some subgroups are too limited to draw any conclusions. The time use of all respondents was categorized to the household types mentioned above. The time use of all one-earners, all two-earners who answered that they were main or second breadwinner, of all partners of a certain household type, as well as the time use of the head of one-parent families, of single people and other members of the household was averaged between sexes. Not all subgroups were big enough to allow a further subdivision.

Table 4.6.

Weekly average of unpaid working hours per household type in 1985 plus 1990

\begin{tabular}{lrrrr}
\hline & N & Male & N & Female \\
\hline One-eamers & 1445 & 21.4 & 59 & 26.3 \\
Partners of one-eamers & 33 & 31.7 & 1346 & 47.2 \\
Two-earners: & & & & \\
- main breadwinner & 600 & 16.7 & 39 & 22.0 \\
- second breadwinner & 17 & 20.9 & 520 & 35.2 \\
One-parent family & 37 & 21.4 & 107 & 42.1 \\
Single people & 307 & 18.7 & 583 & 30.9 \\
\hline Members of family & & & & \\
$12-18$ & 391 & 6.1 & 417 & 9.1 \\
$19-24$ & 267 & 9.6 & 158 & 15.4 \\
$25>$ & 70 & 10.0 & 19 & 18.0 \\
\hline
\end{tabular}

Source: Micro data Steinmetz Archief

Table 4.6. shows that female main breadwinners are a rare phenomenon. Partners of one-earners and second breadwinners in a two-earner situation are practically always female.

Table 4.6. illustrates that in all household types women spend more hours on unpaid work than men. Even if the female is the main breadwinner her average 
number of unpaid hours is higher than that of her male counterpart. On average the single female spends more hours in her household than her male counterpart. It is remarkable that even female children in the age group 12-18 spend more hours on unpaid work than male children of the same age group. The difference between sexes becomes more significant the older the children get.

It is evident from table 4.6. that partners of one-earners are the leaders in unpaid work followed by female heads of one-parent families and second breadwinners in a two-earner situation. One would expect male one-earners to spend the least hours on unpaid activities, because their wives do not do any paid work. This turns out not to be true: it is the male main breadwinner in a two-earner situation who averagely spends the least hours on unpaid activities. An explanation is that one-earners are concentrated in families with young children and in farnilies of 50 years and over.

In families with young children the number of unpaid hours is higher (Knulst and Van Beek 1990 p.59; Van der Lippe and Liphuis-Nell 1994 p.49). A growing percentage of young mothers participate in the labour market. In 1991 it was 43 to $58 \%$ depending on the source of information (Ministry of Social Affairs and Employment 1994 annex 1; Maessen van den Brink et all 1995 p.38),

\subsection{Summary and conclusion}

In this chapter the basis for the calculations of the value of unpaid work are four time use surveys carried out by a commercial market research bureau Intomart, in the years 1975-1990 on instruction of, among others the Dutch Broadcasting Corporations and the Dutch Social and Cultural Planning Office. The input of time was multiplied by three different wages: the legal minimum wages per week, the wages of a home help (gezinsverzorgster), a professional help in the household employed by specialized organizations for household help subsidized by the government, and the average gross wages of an adult employee working full-time. All wages were gross wages plus employer's contribution in social security.

Unpaid work has been defined as hours spent on household work, care of the family, shopping, do-it-yourself activities and voluntary work. The Dutch population of 12 years and older spent 1.5 to 1.9 hours more on unpaid work per year than it did on paid work in the period 1975-1990. If unpaid work of the active population of 25-64 years of age is considered, unpaid work ranges from 138 to $174 \%$ of paid work. Estimations of the value of unpaid work for the whole population range from $51 \%$ of GNP to $110 \%$, depending on the year and the chosen wages. The value of unpaid work of the active population in the age group 25-64 ranges from 36 to $78 \%$ of GNP.

The average workload of paid and unpaid work of the entire Dutch population did not increase for men in the period 1975-1985, except for the age groups 35-49 
and $65+$. For women the average workload remained the same in all age groups except the youngest one. Behind this average it turned out that the workload of people younger than 35 years and older than 50 years decreased or remained the same, whereas the average workload of people between 35-50 years of age increased.

Men's share in unpaid work has increased. Their share rose from 29 to $33 \%$. This increased share is mainly due to a decrease in the number of hours of unpaid work by women. For both men and wonnen household work is the most time consuming unpaid activity.

In all household types women spend more hours on unpaid work than men. Even if the female is the main breadwinner her average number of unpaid hours is higher than that of her male counterpart. 



\section{THE SYSTEM OF NATIONAL ACCOUNTS}

The Blue Book's borderline between subsistence output to be included in production and consumption, and household activity to be excluded, reflects a sexist view that is gradually changing" (Richard Ruggles in a 1982 UN report).

\subsection{Introduction}

Unpaid work is absent in National Accounts and other statistics. The debate whether unpaid work should be taken into account in statistics is as old as National Accounts. What would be the effects on the measurement of statistics and economic phenomena if the value of unpaid work were implemented?

Section 2 of this chapter tells what is measured by the system of National Accounts. Section 3 deals with the long-lasting debate about the imputation of unpaid work in the National Accounts whereas in section 4 this imputation is globally executed for the 1990 National Accounts of the Netherlands. The imputation of unpaid work would lead to a change in the measurement of welfare, economic growth and the business cycle if national income per head is taken as a criterion. This is the subject of sections 5.5.1 and 5.5.2. In sections 5.5.3 and 5.5.4 it is argued that the measurement of employment and unemployment would not change much if paid and unpaid work are measured separately. Section 5.5.5 measures the size of consumption and investments if unpaid work and depreciation of durable household goods is added. In section 5.5.6 it is argued that Pareto optimal allocation does not have much meaning if unpaid work is absent. The essence of section $\mathbf{5 . 5 . 7}$ is that economizing on government expenses nearly always leads to an extra burden for unpaid workers. A summary and conclusions follow in section 6.

\subsection{What is measured by the System of National Accounts?}

From the early days of the formulation of National Accounts by Sir Williann Petty and Gregory King in seventeenth century England, there have been lively debates as to what they should include, how items should be measured and how they are to be put together. From the beginning on one of the points of the debate was whether the value of unpaid household work should be counted as production. Alfred Marshall (1890) said that services rendered by members of the familly should not be counted as part of the national income(12). One of the oldest puzzles in the theory of national income statistics is the question whether national income decreases if a man marries his housekeeper. The answer is yes,

\footnotetext{
12 Alfred Marshall:"Erinciples of Economics" (1979 p.434)

"But it is best here to follow the common practice, and not count as part of the national income or dividend anything that is not commonly counted as part of the income of the individual. Thus, unless anything is said to the contrary, the services which a person renders to himself, and those which he renders gratuitously to members of his family or friends".
} 
because a marketed activity disappears, although the total flow of goods and services remains the same (UN 1977 p.11).

The question whether the value of unpaid work should be part of national income crops up again and again in the discussion about improvement and refinement of National Accounts. Many calculations of the value of household labour have been made during this discussion. Unpaid household work however is only one of the many items of this debate, although experts state that this omission has long been recognized as the major one in the National Accounting system (Gronau 1986 p.296; Eisner 1988 p.1667).

Although some aspects of society were measured before 1900, the System of National Accounts was only developed in the twentieth century, in particular after World War II. As society became more and more complex governments and other policy makers were in great need of an overview of all the streams of money, goods and services within a country and between countries. National Accounts is an macro-economic overview of the whole economic process. In 1947 Stone published a system of National Accounts with five sectors: Productive Enterprises, Financial Intermediaries, Insurance and Social Security Agencies, Final Consumers and The rest of the world. Per sector four accounts were set up: an operating account, an appropriation account, a capital account and a reserve account (Stone 1947).

The first United Nations guidelines for the System of National Accounts were published in 1952. The 1952 SNA established the National Accounts as the primary body of economic data that countries should develop as the basis for reporting on the growth and development of their economic systems and as a major tool for the formulation of economic policy (Ruggles 1982 p.3). Elements of the economic process are: production, income distribution, consumption and finances (Statistics Netherlands (SN) 1991 b, p.189).

This system has permanently been improved and refined by the United Nations, the Organization of Economic Cooperation and Development (OECD) and the European Economic Community (EEC). It now contains 7 sectors: Productive Enterprises, Banking, Insurance Companies, Government, Social Security funds, Households and The rest of the world. Between these sectors and subsectors all economic relations or transactions are registered as well as the transactions with other countries. Macroeconomic data such as national income and national product, consumer expenditures, savings and investments, import and export are measured in the National Accounts (SN 1991 b p.104-168).

\subsection{The debate about imputing the value of household services in National Accounts}

In some countries the value of household work was accounted in the National Accounts during a (short) period. Studenski (1958) reports that Hungary, Italy and 
Sweden imputed the value of unpaid domestic services in their national incomes in the nineteen thirties (Studensky 1958 p.177). In a study for the OECD Brathaug (1991) mentions that Norway imputed the value of housewives work in the National Accounts between 1935 and 1949. This imputation was made with the help of population census data, since time use studies were not available then. The value of unpaid work was determined on the basis of annual wages and the value of roon and board for maid servants in the country and for domestic staff in towns. In 1949 Norway stopped these imputations because internationally comparable figures were needed (Brathaug 1991 p.3 and 12).

The debate about imputing unpaid household labour into National Accounts and proposals how this has to be done, has been going on since.

Arguments against imputation in the National Accounts are:

Doubt about the question whether the productive activities of household work can be characterized as economic processes, the net product of which should be evaluated and included in the national income. "The conditions under which they are carried on and the factors that affect the amount of income from them are so vastly different from those that bear upon activities whose products usually appear on the market place that it seems best to exclude them" (Kuznetz 1941 p.431). In a report for the Statistical Commission and Economic Commission for Europe prepared by the United Nations Statistical Office it is doubted that evening and night care of children is an economic activity because it is not performed as a separate identifiable service (UN 1979 p.11).

A second argument against imputation of unpaid work is that it would lead to big changes in Domestic Product which would damage its usefulness as an indicator for the development of the market economy (UN 1977 p.2). This is also one of the arguments why the 1993 revised System of National Accounts, the new Blue Book, again excluded household services. They are excluded because "the relative isolation and independence of these activities from markets, the extreme difficulty of making economically meaningful estimates of their values, and the adverse effects it would have on the usefulness of the accounts for policy purposes and the analysis of markets and market disequilibria-the analysis of inflation, unemployment etc.". However, housing services are included in the SNA "so as to avoid distorting estimates of the production and consumption of housing services when the ratio of owner-occupied to rented dwellings varies over time and space" (Chadeau 1992 p.87). Chadeau argues that the same kind of distortions may arise with other domestic and personal services produced for own consumption. For example, the substitution of hired cooks, restalirant meals or prepared food instead of home cooking (Chadeau 1992 p.87). Chadeau argues that there are various other areas in National Accounts where the quality of data is less than satisfactory. "If enough thought and resources are devoted to the problem, measures of household production are not necessarily more difficult or more dubious than measures of financial services or public administration" (Chadeau 1992 p.88). In the end Chadeal agrees with Harrison and other statisticians (Lützel 1989 p.338; Brathaug 1991 p.4; Schäfer 1992 p.3; Kazemier and 
Exel 1992) that a household satellite account in which the value of this production and its use would be described in detail alongside the conventional SNA statistics, would be a solution to this problem (Chadeau 1992 p.89).

A third argument against imputation is that income generated from household production must be consumed in the household and cannot be saved or used to purchase other goods and services. Brathaug (1991 p.3) argues that imputed income does not have the same significance as monetary income: monetary income leaves the consumer free to choose among the goods and services available on the market, whereas imputed income from household production can only be used to purchase the output from that production (Brathaug 1991 p.3; see also Homan 1991 p.9). This subject will be dealt with again in chapter 8.

\section{Arguments in favour of imputing are:}

The general welfare of a nation over time or the rate of growth of real output in the economy as a whole can better be measured if nonmarket activities are taken into account. The growth of real output or the degree of economic well-being should not be influenced simply by variation through time in the share of economic activity conducted through markets (Ruggles 1982 p.24; Eisner 1988; Chadeau 1985 p.238). Eisner's view is a very clear one: "International and intertemporal comparisons that ignore nonmarket activity risk domination by particular and changing international arrangements and are for many purposes seriously misleading. Exclusion of nonmarket output will result in incomplete and possibly misleading measures of product. This point acquires particular force where production has in fact been undertaken with and without market transactions at different periods of time"(Eisner 1988 p.1621).

Especially when comparing welfare or growth rates between developed and developing countries the omission of nonmarket work distorts the view. Subsistence activities are widespread in developing countries. As economic development proceeds, the organized market sector in developing countries is likely to grow whereas the informal household sector is likely to shrink. Part of what is taking place on the market sector is absorbing resources formerly used in de household sector. In developed economies some of the changes between market and household sectors take the reverse form: public transport yields to private cars, the local laundry yields to individual washing machines or to wash-and-wear clothing, the carpenter or garage mechanic yields to do-it-yourself activities (Blades 1975; UN 1977 p.7 and 9; UN 1979 p.3; Peskin and Peskin 1978; Chadeau 1985 p.238, Eisner 1988; Juster and Stafford 1991; Kazemier and Exel 1992).

Nordhaus and Tobin attracted much attention by their 1972 presentation of two new measures for economic welfare: Actual and Sustainable Measure of Economic Welfare (MEW). Actual MEW is a comprehensive measure of annual real consumption of households. Sustainable MEW is the amount of consumption that is consistent with sustained growth per capita in consumption at the trend rate of technological progress. Imputation of unpaid work is one of 
the main components of their MEW (Nordhaus and Tobin 1972 p.10). Similar attempts were made by Zolotas, as quoted by Eisner (1988), who constructed a measure of "Economic Aspects of Welfare" (EAW) for the United States for the years 1950 to 1977 (Eisner 1988 p.1633). Another attempt was made by Dale Jörgensen together with Fraumenie, Christensen and Pachon (Eisner 1988 p.1636).

A second argument in favour of imputing unpaid work in National Accounts is that conventional National Accounts do not measure cyclical fluctuations in income and production accurately enough, nor their allocation to current consumption and accumulation of capital for the future. Fluctuations in household activities, transport by family car, subsistence activities in less developed countries are not measured (Eisner 1988 p.1613-1614; Kuznets 1941 p.432). Current consumption is distorted because household and government purchases are identified as "final products" and goods and services bought by business as "intermediate product", unless they are deemed "capital" (Eisner 1988 p.1612-1614). Expenses on durable commodities other than houses are taken as consumption instead of imputed income from these durable commodities (Kuznetz 1941 p.420).

A third argument is that in the comparison of welfare of individuals or households within a nation not only money income should be taken, but the whole package of goods and services an individual or household has available (Peskin and Peskin 1978 p.72). Real household incomes of households with a housewife are higher if household services were included. Households where more than one member of the family has a (labour) income, but where unpaid household services are smaller, are upgraded (Hagenaars, Homan and Van Praag 1984; Homan 1988 and 1992).

A fourth argument is that the vast increase in the numbers and size of in-kind governmental programmes is a reason to pay more attention to nonmarket activities (Peskin and Peskin 1978 p.72). The reverse is also true: if the government economizes on health care or education, informal care or informal help is considered a substitution. In the Netherlands for example the number of days in hospital after an operation has been curtailed. The government expects the family to take over nursing the patient. Old people's homes have waiting lists. The government expects neighbours, friends or family to care for elderly people who can no longer look after themselves. The government expects socalled "reading-mothers" to help in school with pupils who stay behind.

A fifth argument was put forward by the International Women's Conferences organized by the United nations. The 1975 International Conference in Mexico-City recommended measurement of household and other work at home (UN 1974 no.46 j.) In 1980 the International Conference in Copenhagen asked for a system to calculate the value of unpaid work (UN 1980 no.95). The 1985 International Conference in Nairobi wanted "a thorough review and extensive development of improved statistics and indicators on the situation of women compared with men, over time and in all fields" (UN 1986 par. 120 and 122). The 
arguments were that the current contribution of women-farmers is not recorded. As a result it is difficult to obtain the training, credit facilities and appropriate technology needed by these women-farmers. Another argument was that the unrecorded contribution of women to society in terms of child care frequently means a break in paid employment with lower aggregate eamings and lower social benefits over life. The major increase in the number of women caring for one-parent families makes that more women face poverty not only in middle and old age but also in the struggle to maintain their children.

The United Nations Human Development Report 1995 puts it like this: "The monetization of the nonmarket work of women is more than a question of justice. It concerns the economic status of women in society. If national statistics fully reflect the "invisible" contribution of women, it will become impossible for policy-makers to ignore them in national decisions" (UN 1995 p.6/7).

Not only the United Nations but also the Organization for Economic Cooperation and Development and the European Economic Community (UN 1986; OECD 1992; EEC 1992) have pleaded for imputation time and again because, as Galbraith once remarked, "What is not counted, is usually not noticed" (Galbraith 1973 p.79).

Already in 1982 Ruggles expressed the view that the guidelines of the SNA reflect a sexist view. In his report for the Economic and Social Council of the United Nations he pointed out that subsistence activities, which had been included, were male activities for the greater part, whereas household activities, which had been excluded, were female ones. "Thus winemaking is included, cooking is not; caring for animals is, caring for children is not and communal voluntary projects like road building and similar activities are, but those of women's groups running voluntary community service programs like libraries, health services and school services are not" (Ruggles 1982 p.24).

Waring (1990) has written down a flaming analysis of the way in which women are rendered powerless by National Accounts as they refuse to value women's productive but unpaid work within the home. She argues that unpaid work as well as environmental pollution should be part of the United Nations System of National Accounts. Waring's analysis and arguments will be returned to in chapter 8.

Eisner (1988) describes, analyses and compares the attempts of six American economists to improve the System of National Accounts. The major extension common to all of the attempts, except one, is the imputation of nonmarket household work. Other items are the inclusion of all government production, nonmarket production of the nonprofit sector, imputations for the value of leisure, the development of better measures of investment like the acquisition of consumer durables and government expenditures for structures and equipment and the inclusion of expenditures for education and health (investment in human capital), adjustments for changes in the environment, subtraction of 
government expenditures for police, defence etc.

Eisner (1988) himself proposes a "Total Incomes System of Accounts" (TISA), designed to include the income corresponding to all consumption and capital accumulation, market and nonmarket. In production he included the nonmarket services of government and household capital plus unpaid household labour and the opportunity costs of students' time. TISA consumption was $53.8 \%$ greater than conventional consumption in the National Accounts, because Eisner added nonmarket services from tangible capital in the household as well as unpaid household work (Eisner 1988).

Hicks (1940, as quoted by Eisner 1988) already poses the possibility that the measurement of goods and services in a social accounting system may require the use of more than a single set of value weights. "As national income calculations are used for all sorts of purposes, we may have to be prepared to use more than one system of weights. It is not at all obvious without examination that the same system of weights which is appropriate for comparing real income over time is also appropriate for studying questions of distribution. There may be more than one Money Value of the Social Income, each corresponding to a different purpose of calculation" (Hicks 1940 p.106). Peskin and Peskin (1978) also plead for the simultaneous adoption of more than one valuation. "If the objective of National Accounts is to provide an "information framework", this framework embodies more than the final set of accounts. Developing these data with the National Accounting structure in mind can serve to strengthen these data in two respects:

- it helps assure completeness in coverage;

- it helps assure definitional consistency with other economic data", they argued (Peskin and Peskin 1978 p.89).

Statisticians plead for more than one set of accounts as a more flexible and useful way (Begeer and van Tuinen 1984 p.44). They state that the aim of imputing unpaid work is not to reshape the National Accounts, but to consider supplementary measurements. National Accounts would be unsuitable for analytical purposes, particularly business cycle analysis, because household production was an estimated imputation (UN 1977 p.66; SN 1991 b p.190; Brathaug 1991 p.3; Kazemier and Exel 1992 p.1) (Note that the argument against business cycle analysis is used in the reverse sense by Kuznetz (1941; Eisner 1988).

On this subject Harrison (1990) remarks that: "despite this preservation of the production boundary in more or less the same place as at present it is recognised that for other purposes and, in particular for the study of welfare, it will be appropriate for separate analyses to be undertaken with production boundaries defined more widely. It is expected that such analyses would also be undertaken in the form of specialised satellite accounts which will be described in the handbook on the household sector".

An attempt to incorporate informal production into the concepts of the SNA was made by Kazemier and Exel (1992) of Statistics Netherlands. They added the 
informal sector to a social accounting matrix (SAM) of the formal economy. In their opinion this extended SAM could be considered a prototype for a SNA-module on total production. They extended the production boundary by including all productive activities, which did not contribute to the national income as currently defined, in which unpaid labour was involved and which could also be done by others to obtain the same results. They argue that such a module could serve to study the effects of increased female labour force participation on consumption and national income. The quantification of informal production was based on time use surveys conducted by Statistics Netherlands in 1987. The magnitude of informal production is, according to the time use studies of $\mathrm{SN}$, expressed in working years, 1.5 times the size of formal production (Kazemier and Exel 1992).

Beneria (1995) concludes that the implementation of these efforts is now primarily a matter of political will (p.1844). I agree that if enough thought and resources are devoted to the problem, the practical problems of estimating the value of unpaid work could be solved. In my view the only valid argument against imputation is the major breach in National Accounts, because the magnitude of the value of unpaid work will have a major influence. It would harm the usefulness of the accounts for policy purposes. A satellite account seems to be a reasonable improvement. However, another solution could be to incorporate unpaid work into National Accounts and use the old and the new National Accounts during a certain transition period. Therefore in the next section I will try to implement unpaid work in the Dutch National Accounts as well as in a Social Accounting Matrix.

\subsection{Unpaid work in the Dutch National Accounts}

Dutch National Accounts follow the recommendations of the United Nations and European Community about the system of National Accounts with a few exceptions. In 1998 or 1999 all members of the European Community are obliged to follow the revised system of the European Community (ESA). The Dutch National Accounts register transactions between 7 sectors: Nonfinancial enterprises, Credit Institutions, Insurance companies and Pension funds, Central and local government, Social security funds, Households and Rest of the world.

In each sector a distinction is made between five different accounts: Goods and services transactions, Primary and secondary income distribution, Consumption and savings, Capital formation and Capital transfers. Each transaction is registered twice: on the debit side and on the credit side. A code is used to indicate the giving post and the receiving post.

In the Goods and services account the deliverance of goods and services between sectors and within a sector has been registered. Net added value of each sector can be defined in this account. In the Incorne distribution account the payment of the factors of production as well as indirect taxes and subsidies can be found in the 
Primary income distribution. Income transfers, being direct taxes and social security benefits, have been registered in the Secondary income distribution. The outcome is the Disposable income, which can be used for consumption and savings in the Consumption and savings account. The destination of savings has been registered in the Capital formation account. The surplus of income can be found in this account, the destination of which has been registered in the Capital transfer account.

Although several arguments have been mentioned in section 5.3 against taking the value of unpaid work into the National Accounts, these difficulties can be overcome, as is shown in table 5.1. If the value of unpaid work is put into the National Accounts only the sector Households would have to change. This is shown in table 5.1. New transactions or transactions which change in size are printed in bold. If necessary new codes were added. (see for the calculation of the value of unpaid work at minimum wages chapter 4, table 4.5.1.).

Unpaid work can be divided into household production and voluntary work. Because the time use data do not allow to make a distinction between voluntary services rendered directly to other households and voluntary services rendered via nonfinancial organizations such as homes for the elderly, hospitals and schools, all voluntary services are supposed to be rendered via nonfinancial enterprises.

It was pointed out by several experts (Nordhaus and Tobin 1972, p.9; Kendrick 1979 p.357, Eisner 1988 p.1672; Chadeau 1985 p.250; Lützel 1989 p.342; Brathaug 1991) that, besides the value of unpaid work, calculations of home production should comprise the services of capital goods used in the household. Personal consumption expenditures for durables and semi-durables should be reclassified as investments. Estimates of the services of these goods would then be put back into consumption. Nordhaus and Tobin evaluated the household capital services at $10.1 \%$ of GNP, Kendrick at $10.2 \%$, Eisner at $11.9 \%$ (see Eisner 1988 p.1672).

Following these footsteps I took all 1985 expenses for furniture, heaters, washing machines, TV sets, cars etc. as Investments of the sector Households (see table S.80.5 of NA 1990). 
1000 80-10

$100080-40$

$100080-50$

$100080-61$

$100080-90$

$100080-80$

$120080-80$

$211080-40$

$211080-50$

$621080-80$
1. Goods- and serviges transactions

Deliverance by:

Enterprises

226610

Credit institutions

1020

Insurance companies

5250

General govemment

900

Rest of the world

41550

Household production

245034

Depreciation

31000

551364

2. Income distribution

a.primary income distrbution

Income from:

credit institutions

1620

insurance companies

Primary income

b.secondary income distribution

$310080-61$

$321080-10$

$321080-40$

$321080-50$

$321080-61$

$3210 B 0-63$

$322080-63$

$340080-61$

$340080-90$

$631080-80$
Direct taxes

Social premiums accounted to:

enterprises

credit institutions

insurance comparies

general government

social security

premiums social security funds

Unrequited income transfers:

general government

rest of the world

Disposable income
39810

810

100

10

3760

30

85990

2610

2530

558354 
Table 5.1. Acounts for the sector households BENEFITS (bn Dutch Guilders)!

$130080-80$

$141080-80$
1.Goods- and services transactions

Consumption expenditure

Inveatments
491374

59990

551 364:

2. Income distribution

$201010-80$

a.primary income distribution

Wages: enterprises

122710

credit institutions $\quad 5330$

insurance companies 2930

general government $\quad 32280$

social security 1550

rest of the world 1300

Social premiums:

enterprises 35200

credit institutions il 600 .

insuranc cornpanies $\quad 870$

general government 12640

social security 440

Income from:

enterprises $\quad \mathbf{4 3 4 1 0}$

credit institutions $\quad 10450$

insurance companies $\quad 870$

general government 4940

rest of the world 1930

Interest accounted to pension and insurance funds 31080

Income in kind (voluntary work) 21310

Income in kind (household production) $\quad 245034$

575874

b. secondary income distribution

$621080-80$

Primary income

574214

$331010-80$

Social benefits direct from:

enterprises $\quad 810$

credit institutions $\quad 100$

insurance companies 10

general government $\quad 3760$

social security 30

Social security benefits $\quad 82230$

Supplements to pensions $\quad 130$

Social Assistance benefits $\quad 21510$

Other unrequited income transfers:

$\begin{array}{lr}\text { general govemment } & 10170 \\ \text { resit of the world } & 1040\end{array}$

$340090-80$

restt of the world

694004 
Table 5.1. - continued: Acounts for the sector households COSTS (continued)

\begin{tabular}{|c|c|c|}
\hline & 3 Consumption and savings. & \\
\hline $130080-80$ & Consumption & 491374 \\
\hline \multirow[t]{4}{*}{$641080-80$} & Savings (net) & 66980 \\
\hline & & 558.354 \\
\hline & 4. Capital transactions & \\
\hline & Capital formation & \\
\hline $141080-80$ & Gross Investments & 59990 \\
\hline \multirow[t]{5}{*}{$646080-80$} & Capital Transfers & 37990 \\
\hline & & 97980 \\
\hline & 5. Capital transactions & \\
\hline & Capital transfers & \\
\hline & Pension-and insurance premiums: & \\
\hline $401080-50$ & insurance companies & 19140 \\
\hline $401080-90$ & rest of the world & 20 \\
\hline $402080-50$ & Pension-and insurance premiums accounted & 31080 \\
\hline & Unrequited capital transfers: & \\
\hline $420080-50$ & general government & 820 \\
\hline $420080-90$ & rest of the world & 660 \\
\hline \multirow[t]{2}{*}{$430080-00+651080-80$} & Balance land sales+ balance financial means & 5.220 \\
\hline & & 56.940 \\
\hline
\end{tabular}

In the sector Households the following changes have been made

(amounts are in bn Dfl):

Consumption expenditure was

I subtracted : - Expenses for Consumer Durables 1985

I addled

: - Household production

245,034

- Voluntary work

- Interest on Capital invested in Consumer Durables(13)

6,300

Gross Investments in Consumer Durables can be found on the credit side under the new post 1410 80-80:

Expenses for Consumer durables in 1985

Deliverance by enterprises (1000 80-10) was

13 Total expenses for Consumer Durables in the period 1976-1985 were bn Dfl. 310,730 in prices of 1985. (SN 1991 bi table $S 80.5$ posts $3400+3500+3600+3700$ ). Depreciation is 31,000 . Interest is $0.04 x$ $0.5 \times 310,730=6,300$ 
$631080-80$

$641080-80$

$120080-80$

$646080-80$

$410050-80$

$410090-80$

$420061-80$

$420063-80$

$420090-80$
3. Consumption and savings

Disposable income

558354

4. Capital transactions

Capital formation

Savings (net)

66980

31000

97980

\section{Capital transactions}

Capital transfers

37990

Balance pension and insurance funds:

17440

insurance companies

Capital transfers:

630

general government

social security

670

The value of Household production $(245,034)$ has been registered on the debit side (post 1000 80-80) of the Goods and Services Account as well as Depreciation (post 1200 80-80). Household production, Voluntary work and Interest on Consumer Durables create Primary Income $(6210$ 80-80) on the debit side. Interest on capital invested in consumer durables is $4 \%$ and is added to Income from enterprises (2110 10-80). Voluntary work and Household production can be found as Income in kind on the credit side of the Primary Income Distribution as new posts (2500 $80-100$ and $250080-80$ ). Savings (6410 80-80) was 37,990 and is augmented with Consumer durables bought in 1985 to 66,980 . 
Table 5.1. - continued: Accounts for the sector non-financial enterprises COSTS (bn Dutch Guilders)

\begin{tabular}{|c|c|c|}
\hline & $\begin{array}{l}\text { 1. Goods-and services transactions } \\
\text { Deliverance by: }\end{array}$ & \\
\hline $100010-40$ & Credit institutions & 1620 \\
\hline $100010-50$ & Insurance companies & 1740 \\
\hline $100010-61$ & General govemment & 2480 \\
\hline $100010-90$ & Rest of the world & 198840 \\
\hline $120010-10$ & Depreciation & 39760 \\
\hline $601010-10$ & Value added & 351250 \\
\hline
\end{tabular}

$201010-80$

$201010-90$

$202010-80$

2500 80-10

$211010-40$

$211010-50$

$211010-61$

$211010-63$

$211010-80$

$211010-90$

$220010-61$

$621010-10$

$310010-61$

$331010-80$

$631010-10$

$141010-61$

1420 10-10

$646010-10$

$420010-61$

$430010-00+651010-10$
1. Goods- and services transactions

Credit ince by:

Insurance companies

1740

2480

351250

595690

\section{Income distribution}

a.primary income distribution

Wages to:

Households

122710

Rest of the world

Social premiums

1220

Voluntary work

35200

Income enterprises:

Credit institutions

21310

Insurance companies

25130

126130

General government 26130

Social insurance $\quad 110$

Households $\quad \mathbf{4 3 4 1 0}$

Rest of the world 15000

Indirect taxes $\quad 48500$

Primary income $\quad 26310$

376810

b. Secondary income distribution

Direct taxes

11910

810

Social benefits by emplpoyer

14400

Disposable income

27120

4. Capital transactions (capital formation)

Investments

68840

Stocks

2500

Income surplus

$-17180$

54160

5. Capital transactions (capitaL transfers)

General government

1090

Surplus land sales + financial funds 
Table 5.1. - continued: Accounts for the sector non-financial enterprises BENEFITS (bn Dutch Guilders)

1. Goods- and services transactions

Deliverance to:

$100040-10$

Credit institutions

3710

Insurance Companies

1350

General government

28040

Social insurance $\quad 800$

$100061-10$

Households

2266110

$100080-10$

Rest of the world

263840

Investments

68840

Stocks

2500

595690

\section{Income distribution}

$601010-10$

a. Primary income distribution

Value added

351250

Income enterprises:

$211040-10$

Credit institutions

4050

2110 50-10

Insurance companies

Rest of the world

Subsidies

376810

b. Secundary income distribution

6210 10-10

Primary income

26310

Social premiums

$641010-10$

4. Capital transactions (capital formation)

Savings

14400

Depreciation

39760

54160

\section{Capital transactions (capital transfers)}

$646010-10$

Capital surplus

$-17180$

Capital transfers

General government

9890

$420061-10$

Rest of the world 
In the sector Non-financial enterprises following changes have been made:

Deliverance to Households was:

- is increased by Voluntary work

- and is increased by Interest on Capital Consumer Durables

Value added was

and is increased by the same amount

Voluntary work figures on the debit side under the new post 2500 80-10.

Interest on Capital in Consumer durables has been added to post $211010-80$.

The other five sectors of the National Accounts do not change if unpaid work is imputed. The view of the whole economy of all seven sectors changes of course with the changes in the sector households. To illustrate the size of these changes a macro view is given in table 5.2. of all seven sectors, exclusive and inclusive of the value of unpaid work

Table 5.2 .

Income, disbursements and capital transactions 1985 (bn Dfl.)

(1)

\section{Exclusive}

unpaid work
(2)

$\begin{array}{ll}\text { Inclusive } & \% \text { change } \\ \text { unpaid work } & 100(2-1) /(1)\end{array}$

1. Domestic product (gross, marketprices)

2. Primary income rest of the world

$3(1+2)$ National income (gross, market prices)

4. Capital transfers rest of the world

5. $(3+4)$ Gross disposable income

6. Consumption

7. (5-6) Gross national saving

8. Fixed capital formation

9. Increase in stocks

10. National income surplus (14)

11. Capital transfers rest of the world

12. $(10+11)$ Increase (+) or decrease (-) of finances

- Increase of official reserves

- Investments and credit to the rest of the world

418180
680
418860
-3930
414930
315390
99540
80250
2500
17310
-610

16.700
14610

721824

680

722504

$-3930$

718574

559044

159530

140250

2500

17310

$-610$

16700

14610
73

0 .

72.

0

73

77

60

75

0

0

0 .

0

0

Source: SN 1990 p.38

14 Statistical difference 520 
If the value of unpaid work and the services of consumer durables are added domestic product and gross national income increase by $73 \%$, gross national income by $72 \%$, consumption by $77 \%$, savings by $60 \%$, and capital formation by $75 \%$.

\subsection{Other economic phenomena and unpaid work}

\subsubsection{Welfare and economic growth}

In the preceding sections criticism of National Account experts on national income as an inadequate and misleading measure of welfare and economic growth has already been expressed. In this section the differences in economic growth exclusive and inclusive of unpaid work will be shown.

Weinrobe (1974) calculated that the growth rate of real national product inclusive of household production was $6 \%$ less than that of real GNP in the period 1960-1970: real GNP grew at an annual rate of $4 \%$, real GNP inclusive of household work at an annual rate of $3.76 \%$. If growth which can be attributed to changes in the population, is eliminated the annual difference between the two growth rates was even $10.5 \%$ (Weinrobe 1974 p.89-102).

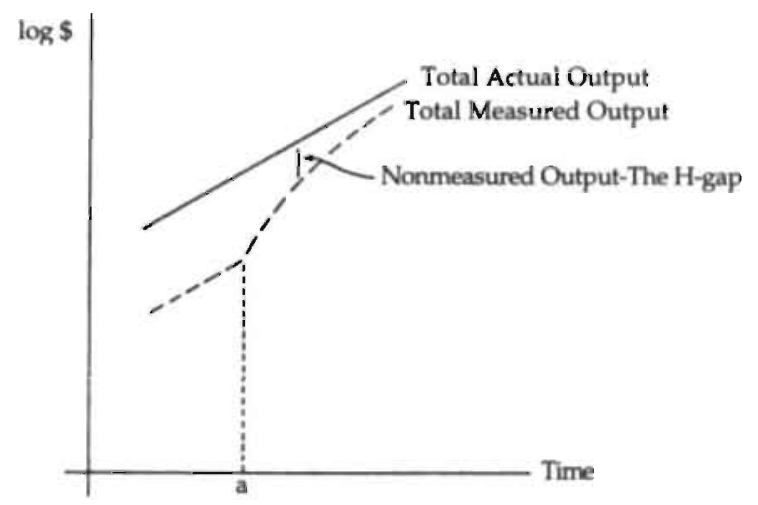

Figure 5.1. (Weinrobe 1974)

Economic growth as shown in the official statistics was higher because American women decided massively to enter the labour market. As a consequence national product as officially measured, grew more than output inclusive of unpaid work.

Chadeau (1992) compares growth rates of gross disposable income exclusive and inclusive of the value of housework for three countries: the United States, Germany and Canada. In her calculations growth rates of Gross Disposable Income (GDI) are lower when housework has been included. Germany is the only exception where the growth rate is higher if the value of unpaid work had been 
included in the period 1964-1970 and remained the same in the period 1970-1974. Chadeau does not explain the differences for Germany.

Devereux and Locay (1992) estimate growth rates in the USA over the period 1930-1985 inclusive of household production and the use of household capital. They find that real growth rates of NNP per capita in the USA in that period would have been 1.3 to 1.4 per annum instead of 1.8 if household production and the use of household capital had been included. Depending on a supposed rate of technological progress in the household sector of $0 \%$ the annual growth rate was 1.3; at a supposed rate of $0.5 \%$ per year the annual growth rate was 1.4. This means that the offical growth rate had been upwardly biased by 22 to $28 \%$ a year (Devereux and Locay 1992).

Table 5.3. shows the growth of Dutch national income per head in the period 1975-1990 as registered in the National Accounts and the growth inclusive of the value of unpaid work. Because time use data are only available once every 5 year, GNP exclusive and inclusive of unpaid work has been compared in those years. In 7 out of 9 calculations growth of registered GNP was higher than growth inclusive of unpaid labour, depending on the wage which was used for the estimation of the value of unpaid work. Exceptions are growth at minimum wage in the period 1975-1980 and growth at average earned wages in the period 1980-1985 when growth rates inclusive of unpaid work were higher.

In the period 1975-1990 the labour market participation of women of 15 years and older increased from $20 \%$ to $36 \%$ (Pott-Buter $1993 \mathrm{pp} .21$ ). The increased labour market participation of women explained, like it did in the USA, why growth rate of national income inclusive of unpaid work was lower than growth rate exclusive of unpaid work.

The exceptions as shown in table 5.3. where growth inclusive of unpaid work is higher than official growth, can be explained if one looks at the development of the different wages. In the period 1975-1980 minimum wages made a jump of $45.5 \%$ against average earned wages, $38 \%$. In the period $1980-1985$ average wage rose $23 \%$ against minimum wage only $9 \%$ (SN Yearbooks 1981.p.329; 1983 p.318; 1990 p.90). 
Table 5.3.

Growth of Gross National Product and growth of GNP plus unpaid work per head of the population in the Netherlands 1975-1990.

\begin{tabular}{lcccc}
\hline & 1975 & 1980 & 1985 & 1990 \\
\hline $\begin{array}{l}\text { GNP per head } \\
\text { GNP per head }\end{array}$ & 16000 & 23900 & 29000 & 34200 \\
incl.unpaid work at: & & & & \\
- minimum wages & 26700 & 39900 & 47400 & 51600 \\
- wage home help & 18100 & 26300 & 31800 & 32100 \\
- average earned wages & 23700 & 33600 & 41900 & 46700
\end{tabular}

\begin{tabular}{|c|c|c|c|}
\hline & $75 / 80$ & $80 / 85$ & $85 / 90$ \\
\hline $\begin{array}{l}\text { Growth GNP per head } \\
\text { Growth GNP+incl..unpaid } \\
\text { work per head at: }\end{array}$ & $49 \%$ & $21 \%$ & $18 \%$ \\
\hline -minimum wages & $50 \%$ & $19 \%$ & $9 \%$ \\
\hline - wage home help & $46 \%$ & $20 \%$ & $9 \%$ \\
\hline - average earned wages & $43 \%$ & $22 \%$ & $13 \%$ \\
\hline
\end{tabular}

Source: $\mathrm{SN}$ and own calculations

Household production influences the magnitude and distribution of welfare between individuals, households and countries. If household production would not exist, if everybody would have to buy all their consumption goods on the market, people with low money incomes, who now are now not considered to be poor, would fall below the poverty line. This does in fact happen to handicapped people and elderly people who can no longer manage their own household production. The costs for producing their meals, cleaning their clothes and their houses are so high that money income is insufficient for part of these groups. The reverse is also true: the magnitude and distribution of money incomes influences the amount and distribution of unpaid labour between individuals, households and countries. Boserup (1971) for example mentioned that in Upper Volta in the sixties money income accounted for about one third of total income as against $75 \%$ in Kenya (Boserup 1971 p. 161 ). Blades (1975 p.53) also mentioned that the amount of subsistence activities in developing countries is very high.

Boserup (1971) does not think it wise that African national income experts recommended not to include in National Income Accounts estimates of subsistence activities other than food and rent for dwellings. "The present system of under reporting subsistence activities not only makes the underdeveloped countries seem poorer than they really are, but also makes their rate of economic growth appear in a more favourable light than the facts warrant, since economic development entails a gradual replacement of the omitted subsistence activities by the creation of income in the non-subsistence sector which is recorded more correctly" (Boserup 1971 p.163). 


\subsubsection{Economic fluctuations and unpaid work}

If unpaid work were registered in National Accounts, the business cycle would not be as severe as it now is. Already in 1941 Kuznetz remarked: "It is especially noted that during severe depressions a drastic contraction in employment and incomes is accompanied by a significant expansion of activities within the household" (Kuznetz 1941 p.431-432). Unpaid work softens the consequences of the business cycle for individual welfare: in depressions when paid work and income decreases, the dip in welfare is partly levelled off by more home production. In times of prosperity, when paid work and income increase, welfare does not increase as much as real money income, because home productions decreases.(15).

Studies of household survival strategies suggest that when under economic distress females in low income households respond by increasing their hours and intensity of household production as well as increasing their labour market participation (Ertürk and Cagatay 1995). In literature this latter effect is introduced as the "added worker effect". It predicts that during economic downturns, if the primary earner becomes unemployed, other family members will enter the labour market to increase family income.

Zienkowski (1991) mentioned that the dramatic decline in production and consumption in Poland between 1976 and 1984 was fully compensated for by an increase in household production (Zienskowski 1991 p.6). Female labour participation did not increase. So the above-mentioned assumption of Ertürk and Çagatay that in a depression female labour market participation as well as (female) household production increased, was not confirmed in the case of Poland. The "discouraged worker effect" holds that during times of high unemployment, when individuals become unempoyed, they may become discouraged and postpone labour force entry or drop out of the labour market and to more unpaid work. Unemployed people try to augment their welfare by doing more houshold work, e.g. repairing clothes and durable household goods and by buying less ready-made products and services and producing them in the household.

Research suggests that the "discouraged worker effect" is dominant over the "added worker effect" (Blau and Ferber 1986 p.92). Moreover, family members entering the labour market may not decrease their unpaid work (the famous "double burden" of women). After examining empirical research of labour market participation of women, Killingsworth and Heckman (1986 p.122) concluded that the participation of teenage and prime-age women is relatively sensitive to cyclical variation, that is to say procyclical.

\footnotetext{
15 Juster and Stafford (1991 p.509) quote work of Ironmonger in which Ironmonger explores the arguments that cyclical sensitivity is a good deal less than is commonly thought because part of the decline in market output during contractions is offset by an rise in nonmarket output. Juster and Stafford regret that because data are not adequate there has been little or no specific quantification of this effect.
} 
In times of prosperity, when employment and income are high and jobs are plenty, teenagers, students, housewives and older people enter the labour market. They try to combine paid and unpaid work by using more market goods and services, like eating out, using the services of a commercial laundry, window-cleaner etc. So in times of prosperity unpaid work is substituted by paid work.

In short unpaid work softens and thereby influences the consequences of economic fluctuations. The reverse is also true: economic fluctuations influence the magnitude of unpaid work.

\subsubsection{Employment and unpaid labour}

In this section two questions are discussed:

1. should unpaid work be implemented in labour force statistics?

2. what is the influence for individuals of paid and unpaid work upon each other?

1. Housewives are not considered to be part of the economically active population, nor are they thought to be unemployed. Yet statisticians label them as part of the "inactive" population. The professional population in most Western countries would be much bigger, if unpaid work would be counted as "active" work. Chadeau does not approve of the idea to include unpaid workers in economically active people. "According to ILO guidelines, economically active persons are persons engaged in production included within the boundary of production of the System. If that boundary were to be extended to include the production for own-account household services, virtually the whole adult population would be economically active and unemployment eliminated" (Chadeau 1992 p.87).

The UN Development Report 1995 states that incorporation of all economic time use (unpaid work $\mathrm{MBH}$ ) is an essential first step to develop policies which liberate men and women from artificial and restrictive roles (UN 1995 p.98). This suggestion has not further been elaborated upon.

Data of the Netherlands Ministry of Social Affairs show that in the year 1986 the Dutch population aged 15-64 years could be classified as follows:

Economically active (unemployed included)

Following day courses

Unfit for work

$57 \%$

Early retirements

$11 \%$

Housewives

Adult population $15-64$ years old 
These data show that $19 \%$ of the population would remain "inactive" if housewives were considered part of the active population. These data also indicate that in the period 1983-1986 the number of economically active people would have been 43 to $45 \%$ higher if housewives would have been counted as economically active (Ministry of Social Affairs 1986 p.17-19). Consequently all statistical measures based on "professional population" would change, including the participation rate, the unemployment rate, the vacancy rate, absenteeism because of sickness and invalidity as a percentage of professional people, unionism. This problem could partly be solved by making a distinction between people doing paid work and those exclusively doing unpaid work. It remains a problem to register people who work part-time on the labour market, but this problem has already been solved in the existing statistics.

2. Unpaid activities exert great influence upon paid activities, among others because unpaid activities are unequally divided over the sexes and between age groups. Women's share in unpaid labour is about $70 \%$ of all unpaid labour. Often younger and older people are legally not allowed to do paid labour or do not wish to do any paid labour. Unpaid labour can be done by practically everybody. There are no legal or cultural hindrances to do unpaid labour. So unless one is too young, too old or too handicapped unpaid labour is the alternative for paid labour. To do paid work in Western countries one must have reached a certain age, have a certain vocational training and suitable jobs must be available.

The reverse is also true: paid activities exert great influence upon unpaid work, because paid and unpaid activities are in competition. People doing much unpaid labour cannot do any paid labour at the same time and people doing much paid labour cannot do much unpaid labour at the same time. Unpaid and paid labour also influence each other: if persons or groups who have done or do much unpaid labour wish to do paid labour, their position on the labour market is hampered by their lack of experience in paid labour. Sometimes persons or groups who have done or do much paid labour are hindered to do unpaid work by their lack of experience in unpaid labour. There are numerous jokes about the helpless widower who cannot cook his own meal or sew a button on his shirt. This hindrance can nearly always be overcome by buying household services on the market.

The dynamic interaction between paid and unpaid work is especially important for women, because women must allocate their time between these two sets of economic activities. Sometimes they overlap each other and lead to greater work intensity. Overlapping activities turn out to be gender specific: women more often than men perform more than one task at the same time. Overlapping takes place when more than one task is done at the same time, for example the combination of "outworking" of industrial homework and the supervision of children (Floro 1995). It is not clear in what way these overlapping activities affect the well-being of women and their children. Overlapping activities can potentially increase the level of efficiency, but they may also lead to increased stress and deterioration in the quality of outputs. Time use surveys which study 
this aspect are scarce. A study by Roldan under 140 poor rural women in Mexico shows strong evidence of emotional and psychological disorders. A study by Wolfe and Haveman under 2.325 women in Michigan indicates health deterioration as a consequence of a combination of child care, market work and housework. A survey by Mingione under 299 self-employed households in southern Italy shows that long hours of market work coupled with long hours of domestic work led to shorter resting hours and to considerable stress (Floro 1995 pp.1920-1925). Women doing "outwork" are often paid by piece, which can lead to rushing and stress. They do not enjoy any legal protection such as minimum wages, they can be dismissed immediately, they have no rights in social security or pensions etc. Often these women are assisted by their children (Bruyn-Hundt 1981; Ministry of Social Affairs 1984; 1988; Steunpunt Thuiswerk 1987, 1988, 1990; Allen and Wolkowitz 1986).

Schäfer (1992) points out that although paid and unpaid work have a number of common features, such as the activities to be performed, they also have specific features which makes it somewhat difficult to compare them. Household activities often require a permanent availability of the individuals concerned, frequent interruptions of the activities, tensions between internal and external factors determine the work. Household work has another emotional and social context than gainful employment. Schäfer considers it to be impossible to fully take into account these aspects of household work in the National Accounts or in a satellite system of the National Accounts.

Characteristics of the labour market position of people doing much unpaid labour (mostly women) are:

- they work only part of their adult life on the labour market and if they work on the labour market they work part-time, in temporary jobs or other forms of atypical employment (European Commission 1993 pp.34-44);

- their hourly wage is lower than the hourly wage of people doing the same job (EC 1993 pp.45-51);

- they are concentrated in fewer professions and sectors of industry than people working full-time (EC 1993 pp.13-23);

- in most countries they are more often and longer unemployed than people working full-time during their adult life (EC pp.24-33);

- they have less rights in social security and pension schemes than people working full-time during their adult life (EC p.32);

- consequently: people who spend a considerable part of their lifetime in unpaid labour have a different position on the labour market than people who work full-time in the productive phase of their life. Their lifetime income is much lower, because they work fewer years, fewer hours per year, earn less per hour, have fewer rights in social security and pensions (see for instance OECD 1988).

Oakly (1980) analysed women's position on the labour market as follows: "In relation to male labor, female labor is characterized as unproductive, marginal, trivial, temporary, intermittent, dispensable, less valuable, less skilled and less 
physically demanding. These stereotypes apply both to female household labor and to women's labor in paid occupations. Thus, it is normative to regard the employment work of women as intermittent (and interruptible) rather than continuous activity; to reinforce the poverty (in relation to the male norm) of women's monetary rewards for paid work by the total lack of renumeration attached to housework; to see both housework and women's paid work as marginal contributions to the national economy" (Oakley 1980 p.8).

In short: employment data would be much higher if household work would be counted as "work". Unpaid labourers work, but they do not receive any money, undifferentiated purchasing power, for their work. Their renumeration consists of purchasing power differentiated in food, clothing and housing. If these unpaid labourers spend part of their life on the labour market, their position is different of those who spent their whole adult life on the labour market working full-time. If paid labourers wish to do unpaid labour, they are hindered by their lack of experience in unpaid labour. This latter hindrance however is not as troublesome as the former, because the renumeration of paid labourer consists of undifferentiated purchasing power, namely money, with which one can nearly always buy substitutes of household services on the market.

\subsubsection{Unemployment and unpaid labour}

Using OECD "standardized unemployment rates" the female unemployment rate has been higher than the male one in all OECD countries except Finland, Japan and the United Kingdom since 1983. The OECD defines Involuntary unemployment as: "those who are not working, who are available to begin to work and who have taken active steps to find work in a recent period (normally taken to be the previous month) (OECD 1988 p.142). Even one hour of paid employment produced a categorization as employed.

The OECD remarks that "a strict application of the definition of unemployment, implies that people who are excluded from employment opportunities for any length of time, may also be excluded from the unemployment statistics" (OECD 1988 p.143).

Unemployment statistics omit people who work part-time or do occasional work while looking for work for longer duration. People who want to work but did not actively search during the last four weeks are also omitted as well as people who want to work but are not available in the next two weeks.

The OECD relaxed these three criterions and found that for all countries considered the effect of relaxing was bigger for women than for men. 
The effect of relaxing the "availability" criterion on the unemployment rates of women and men, 1985

\begin{tabular}{|c|c|c|c|c|c|c|}
\hline & \multicolumn{2}{|c|}{$\begin{array}{l}\text { Standard } \\
\text { unemployment } \\
\text { rate }\end{array}$} & \multicolumn{2}{|c|}{$\begin{array}{l}\text { "Extended." } \\
\text { unemployment } \\
\text { rate }\end{array}$} & \multicolumn{2}{|c|}{$\begin{array}{l}\text { Increase } \\
\text { due to } \\
\text { extension. }\end{array}$} \\
\hline & $f$ & m & $f$ & $\mathrm{~m}$ & $f$ & m \\
\hline Belgium & 17.8 & 7.4 & 18.6 & 7.9 & 0.8 & 0.5 \\
\hline Denmark & 9.5 & 6.4 & 11.4 & 7.1 & 1.9 & 0.7 \\
\hline France & 12.6 & 8.5 & 13.6 & 8.9 & 1.0 & 0.4 \\
\hline Germany & 8.5 & 5.8 & 9.7 & 6.5 & 1.2 & 0.7 \\
\hline Greece & 11.7 & 5.6 & 12.0 & 5.7 & 0.3 & 0.1 \\
\hline Ireland & 19.2 & 17.4 & 21.1 & 18.2 & 1.9 & 0.8 \\
\hline Luxembourg & 4.3 & 2.2 & 4.9 & 2.4 & 0.6 & 0.2 \\
\hline Netherlands & 12.4 & 9.5 & 14.3 & 10.2 & 1.9 & 0.7 \\
\hline United Kingdom. & 11.0 & 11.8 & 12.0 & 12.4 & 1.0 & 0.6 \\
\hline
\end{tabular}

Source: OECD: Employment Outlook 1988 p. 146

A similar revision was executed by Statistics Netherlands in 1986. The percentage of unemployed people as defined in the Dutch Labour Force Statistics was $12.8 \%$, the percentage of people who were willing to work was $18.0 \%$. In the latter percentage people who were willing to work, but did not fulfil the criteria for the definition of unemployment, had also been counted. For women the unemployment percentage was $15.7 \%$, the percentage willing to work was $26.0 \%$. (Einerhand, van den Elshout and Hoogteijling 1986 p.11). These exercises showed that unemployment statistics rose when the criterions were relaxed.

The OECD "Employment Outlonk 1994" mentions that if discouraged workers (3.7 million or $1 \%$ of the 1991 labour force) and involuntary part-time workers (9 million or $2.5 \%$ of the labour force) were added to the labour force as unemployed, the unemployment rate would rise sharply in countries with a relatively low unemployment rate. Women outnumber men in discouraged and involuntary part-time workers. It is not clear whether temporary work (18 million or $5 \%$ of the labour force) increases employment opportunities for the unemployed.

In another publication the OECD concludes that inclusion of household work in the National Accounts would mean that "unemployment would virtually disappear, thus rendering labour force statistics meaningless for employment purposes" (OECD 1991 p.3).

Another suggestion of the OECD as quoted by Bakker (1993) is the concept of a "non-employment rate". This rate is the sum of the inactive (defined as the total working age population minus the labour force) and the unemployed divided by the working age population. This measure is in a sense superior to the 
unemployment rate as it can capture labour market discouragement (Bakker 1993 p.18).

In my eyes a good solution would be if the employment statistics would make a distinction between paid and unpaid employment rates. The unemployment rate could stay as it is now, that is limited to people who seek paid employment.

\subsubsection{Consumption and investments}

Consumption is usually defined as expenses by the household for consumption goods, that is expenses for non-productive purposes. Expenses for buying a house, paying taxes and social premiums are not regarded as consumption. The part of the household income which remains after the paying of these expenses is regarded as savings. Expenses by households for consumer durables such as cars, TV sets, washing machines etc. are regarded as consumption.

If household production would be seen as part of national production, the magnitude of consumption in National Accounts and other statistics would be augmented by the same amount as the value of home production. In Kendrick's 1966 calculations for the USA, consumption of households would have been $28 \%$ higher if household production had been included (Eisner 1988 p.1648). If the value of unpaid work in the Netherlands, as estimated in chapter 4 at minimum wages, would be added to consumptive expenses in the National Accounts total consumption in the Netherlands would have been $89 \%$ higher in $1975,85 \%$ higher in 1980, 75\% higher in 1985 and $69 \%$ higher in 1990 .

Unpaid work influences the structure and direction of consumption as well as the level of consumption. Research shows that families with working wives spend a larger part of family incomes on consumption than families with nonworking wives, total family income held constant. Families with working wives have more cars and spend more money on cars than families with nonworking wives (Strober 1977 p.394-398). Strober remarks that "the effects on employment and prices depend upon exactly which goods and services are demanded and on the relative degree of tightness and monopoly and monopsony power in the relevant goods and labor markets. For example if highly labor intensive child care services are demanded and the labor and product markets associated with these services are rather loose and competitive, then at least in the "first round", an increased demand for child care is likely to have substantial employment effects and few price effects. To the extent, on the other hand, that increased motorcar-associated goods (e.g. gasoline) are demanded, there may be substantial price effects but few employment effects" (Strober 1977 p.398). Strober found no differences in the ratio families with working wives and nonworking wives spend on durable consumer goods. Research in the eighties and nineties confirmed that a working wife has no influence on the ownership of household durables but household income is a significant determinant (Strober and Weinberg 1980; Schor 1991 as quoted by Floro 1995). 
Dutch research by Homan (1992) shows that in the Netherlands families with working wives possess more durable consumer goods such as dishwashers, microwaves, freezers and tumble dryers than families with nonworking wives. These two-earner families spend more money on child care, household help and eating out than one-earner families (Homan 1992. p.38) Contradictory results have been found by Tijdens et al. about strategies of working wives to substitute household labour by capital goods (such as deepfreezers, dryers, microwaves), by having meals in a restaurant, by buying ready made food, by engaging paid household help or by shopping by mail. They found that only paid household help is more used by working than by nonworking wives (Tijdens et al. 1994 chapter 7). Their findings that working wives more often use paid household help are confirmed by research of Van der Lippe and Niphuis-Nell (1994 p.39).

If household production would be seen as part of national production, expenses for capital goods such as dishwashers, motorcars, television sets etc. would be regarded as investments instead of consumption, whereas interest and depreciation on these investments would be viewed as part of consumption (see also section 5.4). Such purchases would then be excluded from consumers' expenditure and replaced by an imputation for the services annually provided by the durable goods (a kind of "rate of return", analogous to the imputed rental value of owner-occupied dwellings used in the National Accounts). The United Nations Statistical Bureau (1977) mentioned two advantages of this treatment of durable consumer goods. The first was that the apparent inconsistency between the treatment of owner-occupied dwellings and that of other durable consumer goods would be removed. The second more important advantage was the better understanding of trends and fluctuations in consumers' expenditures and saving patterns. For this alternative treatment first an estimate of the stock of consumer durables is needed and secondly a reasonable method to impute the annual value of the services they render. The UN Statistical Bureau considered that these advantages did not justify the amount of rather dubious imputations required by the alternative treatment (UN 1977 p.28).

Despite the practical difficulties, several attempts have been made. The UN Statistical Bureau mentioned two estimates of the total value of consumer durables in the United States and one in Japan. The National Bureau of Economic Research estimated a rental for consumer durables in 1969 which did not differ much from the actual purchases in that year (UN 1977 p.30).

Eisner (1988) mentions several attempts to estimate the services of household capital, ranging from $3.7 \%$ to $12.6 \%$ of GNP (Eisner 1988 p.1672). Zolotas (as mentioned by Eisner 1988 p.1634) based the imputed value of services from consumer durables on a variety of depreciation rates and adjustments for rapid obsolescence. The Ruggleses subtracted from consumption the expenses for durables and added practically the same amount to GNP (Eisner 1988 p.1649). Nordhaus and Tobin (1972) subtracted "Purchases of durable goods" and added "Services of consumer capital imputation" They concluded: "that proper treatment of consumer durables has little quantitative effect" (Nordhaus and 
I do not agree with this conclusion and the one reached by the UN Statistical Bureau in 1977 "that the arguments for changing the present system of recording actual expenditures on consumer durables do not seem persuasive" (UN 1977 p.31). Therefore I calculated investments in durable household goods and its depreciation in section 5.3. From this calculation the difference between expenses for household durables (Dfl. 29,990) and depreciation (Df. 31,000) turned out to be $7 \%$.

\subsubsection{Optimal allocation of production factors}

Economists have always asked themselves how optimal welfare could be reached. Production and distribution play an important role in finding an answer how to reach optimal welfare. How to handle interpersonal comparisons of utility? Pareto's answer to these questions is much discussed in economic literature. Welfare of a household and of society as a whole is Pareto- optimal, if production factors are divided in such a way that nobody's welfare can be increased unless someone else's welfare is decreased (Blaug 1981 p.621). Given a certain income distribution the price mechanism causes a state in which no one could achieve a higher level of satisfaction without lowering someone else's satisfaction, provided there is perfect competition on all markets and that production has no "external effects" such as detoriation of the environment and that no collective goods and services are produced. Under these constraints consumers will maximize their utility and producers will have a maximum profit (Hennipman 1977, p.117).

The theorem of Pareto-optimality has been discussed and criticised by many authors (Hennipman 1976; Bergmann 1986; Blau and Ferber 1986; Sen 1982; Hennipman 1992; Woolley 1993; Barker 1993). Some of the topics of this discussion are: Is it possible to increase total welfare by distributing goods in another way if the winners pay the losers a compensating payment? Is it possible to increase total welfare by increasing production (efficiency) and/or changing income distribution (equity)? Sen (1982) criticises the fact that the income distribution can be very unequal without altering the Pareto-optimality: "A state can be Pareto-optimal with some people in extreme misery and others rolling in luxury, so long as the miserable cannot be made better off without cutting into the luxury of the rich; Pareto optimality can, like Caesar's spirit, come hot from hell" (Sen as quoted by Barker 1993).

Another point of discussion is whether total welfare could be increased if income distribution would be changed before the increase in production (Blaug 1978 p.623). Blaug (1978 p.625) concludes that: "efficiency cannot be separated from equity": discussion about the size and distribution of income carnot be separated.

Is welfare economics a positive or a normative subject? Blaug (1978) argues that 
welfare-economics is normative: "there is no such thing as "value-free welfare economics" (Blaug 1978 p.626). Hennipman did not agree and had many arguments why allocation theory belonged to positive economics (Hennipman 1992 p.445).

Woolley (1993) questions the exogenity of the individual utility functions. She argued that some preferences are part of institutional structures. As an example she mentions men's refusal to share household tasks. Bruegel (1993) questions whether the household has a single (joint) utility function or whether the household could be considered as a coalition or collectivity with conflicting interests.

In this discussion the subject of unpaid labour does hardly play a role. The price mechanism which brings about the allocation of production factors does not work for unpaid labour, because unpaid labour (like the environment) does not pass a market. Unpaid work is not divided over people by means of a price mechanism, but is as a matter of course mainly done by women. Economists try to explain the fact that women do most unpaid work and men most paid work as a gainful specialization between the sexes. Following Becker's analysis (1981) the division of labour between the sexes is partly determined by biological differences and partly by different experiences and different investments in human capital (Becker 1981 p.14). "Since the biological natures of men and women differ, the assumption that the time of men and women are perfect substitutes even at a rate different from unity is not realistic. Indeed, their times are complements in sexual enjoyment, the production of children, and possibly other commodities produced by the household. Complementarity implies that households with men and women are more efficient than households with only one sex, but because both sexes are required to produce certain commodities complementarity reduces the sexual division of labor in the allocation of time and investments. Apparently, differences in comparative advantage and in investment have been more important than complementarities because women traditionally have allocated much more time to the household than men have" (Becker 1981 p.23-24).

Becker supposes that the fact that women do more unpaid work than men revealed their preference for unpaid work. The theorem of revealed preference was criticised by Sen (1982). He pointed out that other incentives than economic influence human behaviour, for example "sympathy" and "commitment" (Sen 1982 p.92). Nelson (as quoted by Woolley 1993) added another influence on human behaviour, namely "altruism". "If you get: up in the middle of the night. to feed a baby because you feel sorry for it, you are acting "altruistically"; if you get up when you feel personally better off just putting your pillow over your head, you are acting responsibly. Since after the hundredth or so such occasion one is likely to feel more sorry for oneself than for the child. It is a good thing for children that most parents treat children as a commitment." Sen doubts whether people always have a gains-maximizing answer and argues that admitting behaviour based on other grounds would have far-reaching consequences on the 
In my opinion optimal allocation cannot be discussed without adding unpaid work: unpaid work does not only increase total production and total consumption, it also changes the income distribution as has been shown in chapters 4,5 and will be shown in chapter 6 .

Following the neo-classical explanation that women are not on the labour market or work for less hours on the labour market than men because the shadow wage of women doing unpaid work is higher than their market wage, is no longer a satisfactory one. Now that in the industrialized world women have reached nearly the same level of education, there must be another explanation. Given their almost equal level of education, one could suppose that women are more fit for and prefer doing household work. This is very unlikely. It is as unlikely as stating that all females are equally fit to do household work and that all males are fit to be, let us say, a plumber or a teacher. Nor is it likely that nearly all women prefer unpaid work over paid work. So it follows that the capacities and talents of women are probably not fully used if women are predestined for one type of profession. In short: optimal allocation of labour is not guaranteed unless unpaid labour is part of the economic analysis.

\subsubsection{Public finance}

After the second world war macroeconomic policy was demand oriented by aggregate measures of economic change such as output levels, rates of growth, unemployment and inflation, government surplus/deficit. The nineteen eighties and nineteen nineties are characterised by a discourse in all industrial countries about restructuring global economics in terms of the international division of labour, the global distribution of economic and political power, global finance, the functioning of the Welfare State. In the discussion about government expenditures the accent is put on lowering government and collective spending. More emphasis is put on efficiency and competitiveness, whereas the role of equity has decreased. Although unpaid labour is hardly mentioned explicitly in this discourse, implicitly it plays an important role. Policies concerning taxation, government expenditures, subsidies, social security, exchange rates and monetary policy influence the division of paid and unpaid labour (Bakker 1993). Macroeconomic stabilization and structural adjustment policies implemented in developing countries over the last 15 years have been neither class-neutral nor gender-neutral. Boserup (1970) was the first to point out that the absence of women in development policies made them inefficient. Conceptions and policies of the International Monetary Fund and the World Bank were criticised (Çagatay, Elson and Grown 1995).

Research suggests that women have suffered more than men from the adverse impact of adjustment policies in many countries of Latin America and Africa (Palmer 1995). For example the removal food price subsidies has been analysed in 
terms of changes in monetary income and consumption. However, they fail to analyse changes in the quantity and quality of nonmarket goods and services and the well-being of the family. The efforts to maintain the family consumption level by enlarging household production are not taken into account (Floro 1995 p.1914).

Increasing international division of labour will have different impacts on the structure of employment of countries. The transfer for example of employment from high wage countries to low wage countries will have a different effect on the employment of men and women as more women than men work in low wage jobs. The employment or unemployment of women will have a greater effect on unpaid work than the employment or unemployment of men as long as women are more inclined to do unpaid work. The result of privatization and public sector reforms and cuts in public expenditure and health care is that activities are shifted from the public sphere to the private household, thereby increasing women's burden. Macroeconomic policy takes unpaid work for granted, assuming an unlimited supply of unpaid labour. The hidden equilibrating factor is women's ability to absorb the shocks of stabilization programmes, through more work and less income. Macroeconomic policy is gender blind (Çagatay, Elson and Grown 1995; Beneria 1995).

Decreasing the public sector has a threefold impact, which is greater for women than for men. Firstly: more women than men are dependent on the public sector. There are more female headed one-parent families who live of social assistance. There are more older women than men who are exclusively dependent on a State pension. Secondly: relatively more women than men work in the public sector. Cuts in jobs in the public sector have effects in terms of disappearance of jobs, a way to substitute paid jobs by unpaid work, because elderly or handicapped people become dependent on unpaid care. Women are more apt than men to do unpaid work if they lose their jobs. Thirdly: cuts in subsidies for food, accommodation, fuel, public transportation etc. will put a financial strain especially on people with low money incomes. They will try to maintain their standard of living by doing more unpaid work.

Interest as well as monetary policies will influence the rate of inflation. The higher the rate of inflation the greater the pressure to maintain the standard of living by substituting market products and services by home production.

\subsection{Summary and conclusion}

The System of National Accounts measures all the streams of money, goods and services in a country and between countries. It is a macro-economic overview of the entire economic process. Unpaid work is no part of this system, although this has been a point for discussion from the beginning of the existence of National Accounts. 
Estimation of the value of unpaid work is arbitrary, but can be done and registered in the National Accounts as is shown is section 5.3. One of the arguments against including the value of unpaid work in the National Accounts is that this could have adverse effects on the usefulness of the Accounts for policy purposes. Imputation would signify a major change of the magnitude of production, income and consumption. This difficulty could be overcome by presenting the old accounts and the new version during a transition period. A satellite account or an addendum to National Accounts, in which unpaid work is to be registered, could be a first step towards implementing the value of unpaid work.

In my opinion international agreements and conventions on the procedures and the methods of this addendum are more important and fruitful than endless discussions on the question whether the evaluation of unpaid work should be put into the SNA or put into an addendum. The important thing is that unpaid work becomes visible in National Statistics. 


\section{UNPAID WORK IN INCOME DISTRIBUTION}

"If women's work were accurately reflected in national statistics, it would shatter the myth that men are the main breadwinners of the world" (UN Human Development Report, 1995).

\subsection{Introduction}

Size distributions of income (Statistics Netherlands - SN uses the term: personal income distribution) are constructed by assigning incomes to income units and then arraying the units by size of income. Measures of income inequality based on such constructions are then taken to be rough indicators of inequality in economic welfare. Economists are well aware of the fact that such measures are imperfect. One of the refinements in constructing income distributions is to extend the personal income concept to a statistic which includes the monetary value of household production and to investigate the influence of this extended income concept on the personal income distribution. This extended income concept is used, because researchers think it is a better indicator of welfare and well-being than traditional money incomes as used in income statistics.

This chapter has been organized as follows. Section 2 deals with several problems arising from measuring income inequality. Section 3 presents a few instruments to measure income inequality. Section 4 gives an overview of attempts in economic literature to include the value of unpaid work in personal income distributions. Section 5 presents calculations of income distribution in the Netherlands in 1985 and 1990, which include the value of unpaid work calculated at net minimum wages plus employer's contribution in social security. Summary and conclusion can be found in section 6 .

\subsection{What is measured by traditional income statistics?}

Several problems arise when constructing traditional income statistics, because the choice of the income unit, the income accounting period and the income concept differ from country to country and in the course of time. Income data limit the possibilities to allow for all these differences.

The first problem is the choice of the income unit. The income unit in conventional size distributions is the household. According to the definition of Statistics Netherlands (SN) a household is a group of two or more persons living together in the same domestic household, keeping house together, or a single person, living alone in an independent household (SN 1989 p.12). It is also possible to use the individual income recipient, single or in a household with other individuals, as the basis for income distribution (SN 1993 p.299). The choice of the household as income unit is based on the fact that individual income recipients in households generally pool their incomes and share, more or less 
equally, a common standard of living. The aggregate nature of the household as income unit has been criticised and cited as a source of bias in the measurement of inequality (Danziger and Taussig 1979). On the one hand the pooling of income by household members does not mean that each household should be given an equal weight in the construction of the size distribution. On the other hand, if the individual income is the basis of the construction, children, dependent women and foreigners or residents who for whatever reason have no labour income or are not entitled to social benefits, have an income of zero. This is not representative for their welfare. Generally speaking they are supported by their fathers, husbands or other relatives or charitable organizations. Therefore household income is a better measure of welfare than individual income (Berkman and Den Dulk 1978 p.54-67).

If measuring welfare is the aim of the construction of a personal income distribution, several problems arise. The first one is that the size of households differs. A crude method to correct household income for the number of persons living in a household is to divide household income by the number of persons in the household. However, the needs of adults differ from the needs of children. Households of more than one person have the advantage of economies of scale: shopping for more people is relatively less expensive, more persons use the same bathroom, they watch the same TV. Equivalence scales have been developed to correct for these differences (Schiepers et al. 1993). According to Schiepers et al. an equivalence factor is the quotient of the incone a household needs to reach a certain level of welfare and of the income a standard household needs to reach the same level of welfare (Schiepers et al. 1993 p.7). Schiepers et al. distinguish empirical objective, empirical subjective and normative scales.

A second problem is the period of measurement of income. The income period in conventional income statistics is nearly always a year, because data come from the Treasury. A distinction is made between incomes lasting a full year and incomes lasting only part of the year. Income inequality between incomes over a full year and part of the year can differ as well as income inequality between incones over a year and over a lifetime. These differences disappear in most calculations, because data are not available.

The definition of income is the third problem if income is considered a measure for welfare. Statistics Netherlands distinguished three different definitions of personal income:

- Primary income = labour income, capital income, profits;

- Gross income = primary income and income transfers;

- Disposable income $=$ gross income minus tax and social premiums (SN 1993 a p.39).

A fourth problem is the person to whom the income is accounted. This is especially important to married women, because in most countries the wife's income used to be or still is (partly) accounted to the husband's income (OECD 1985; OECD 1989). Labour income of married women in the Netherlands is 
accounted as personal income. To estimate household income the incomes of members of the household should be taken together.

In conventional statistics only money income is counted. Income in kind is (partly) counted for some groups of economically active people. Income in kind formed by household production and voluntary work is neglected in income statistics.

\subsection{Measuring income inequality}

The measurement of income inequality is a much disputed subject in science (Sen 1973 chapter 2; Odink 1985 p.22). It can be measured in several ways. Normative measures are based on (subjective) value judgments. Positive or conventional measures are based on (objective) methods of calculation. Of the latter the Variance of the logarithm of incomes, the Theil coefficient and the Gini coefficient are used in the next sections (Odink 1985; SN 1989). All three coefficients indicate the level in which the income distribution differs from total equality. All three measure differences in income ratios and not in absolute differences. All three are symmetrical, that is insensitive to an accidental change of two incomes $X_{i}$ and $X_{j}$.

Disadvantage of the Variance of logarithm is that it presupposes a lognormal distribution of incomes. Disadvantage of the Gini coefficient is that, in case the distribution consists of a small number of incomes, the maximum inequality is not the same as when the distribution consists of a large number of incomes, because $\mathrm{N}$ is in the denominator. Advantage of the Theil coefficient is that it is decomposable which means that income differences and changes in income differences can be analysed and accounted to those who cause them. The Theil coefficient is less specifically sensitive to the fact whether income redistribution takes place at low, middle or high incomes (Odink 1985 chapter 2.1).

The formula of the Theil coefficient is:

$\mathrm{T}=\Sigma_{\mathrm{i}}\left(\mathrm{X}_{\mathrm{i}} / \mathrm{Y}\right) \ln \left(\mathrm{X}_{\mathrm{i}} \mathrm{N} / \mathrm{Y}\right)$

and $Y$ is the sum of all incomes.

$\mathrm{T}=0$, if all incomes are the same (absolute equality);

if one individual earns all the income $\mathrm{T}=\ln \mathrm{N}$ (maximum inequality).

The higher the $\mathrm{T}$, the more unequal the income distribution.

T can be dissolved in two components: the weighted inequality inside income subgroups and the inequality between income subgroups (Odink 1985 p.32). The two components will further be analysed and explained in section 6.5.2. 
In section 6.2 equivalence scales, which correct income for size and composition of the household (economies of scale) have already been mentioned. Schiepers et al. (1993) of Statistics Netherlands (SN) developed an empirical objective scale especially for one- and two-earner families, single people and one-parent families. The Schiepers-scale corrects family income for the number of persons, scale economies and the higher costs of living of two-earners compared to oneearners. Total consumption of the family is divided into a collective part, a part consumed by adults and a part consumed by children. A single person household is the standard (equivalence $=1$ ). The difference in equivalence scale is decided on the basis of a regression analysis of the division of income over adults and children in one- and two-earner families. For example the equivalence scale for a one-earner without children is 1.38 , for a two-earner it is 1.42 . This means that a one-earner needs an income which is 1.38 higher than the income of a single person household to reach the same welfare, whereas a two-earner needs an incorne which is 1.42 higher than that of a single person household. A one-earner with one child in the age of $0-5$ years has an equivalence scale of 1.65 compared to 1.69 for a two-earner with one child of the same age etc. The difference between one- and two-earners without children is 0.04 and the difference between oneand two-earners with children is 0.05 . In the Schiepers-scale a distinction is made between families with one to three children and a subdivision according to the age of the oldest child.

In section 6.5.2 the OECD-scale is used. The OECD-scale has been chosen because it has internationally been accepted, it is simple and easy to understand (O'Higgins and Jenkins 1989; De Kruijk 1993). The weight of the first adult is 1, other adults count for 0.7, children under 17 years of age count for 0.5 . The income of a single person is divided by 1.0 , the income of a household of two adults is divided by 1.7 to obtain the income per family equivalence. In the OECD-scale no distinction is made between children of different ages.

Table 6.1. shows the differences between the SN (Schiepers)-scale and the OECDscale.

Table 6.1.

Family equivalence scales of the OECD and SN

\begin{tabular}{|c|c|c|c|}
\hline & & OECD & $\mathrm{SN}$ \\
\hline \multicolumn{2}{|c|}{ Single person household } & 1.0 & 1.0 \\
\hline \multicolumn{2}{|c|}{ One-earner without children } & 1.7 & 1.38 \\
\hline \multicolumn{2}{|c|}{ Two-earners without children } & 1.7 & 1.42 \\
\hline \multirow[t]{3}{*}{ One-earner: } & - one child & 2.2 & 1.66 \\
\hline & - two children & 2.7 & 1.84 \\
\hline & - three children & 3.2 & 2.03 \\
\hline \multirow[t]{3}{*}{ Two-earner: } & - one child & 2.2 & 1.71 \\
\hline & - two children & 2.7 & 1.89 \\
\hline & - three children & 3.2 & 2.08 \\
\hline \multirow[t]{2}{*}{ Single parent: } & - one child & 1.5 & 1.33 \\
\hline & - two children & 2.0 & 1.56 \\
\hline
\end{tabular}


In the Schiepers-scale the correction factor is 0.17 to 0.86 lower than in the OECDscale. Therefore using the Schiepers-scale leads to smaller differences of corrected. net money income per family equivalence as is shown in table 6.5 .

\subsection{The combination of paid and unpaid work in income distribution: an overview}

In economic literature one can find a few attempts to extend the personal money income concept to a statistic which includes the monetary value of household production and to investigate the influence of this extended income concept on the personal income distribution. Researchers used this extended income concept, because they considered it a better indicator of welfare and well-being than money income as used in income statistics.

Bryant and Zick (1985) are the first to incorporate the value of household production in income distribution. They use time data of the 1975-1976 and 1979-1980 Panel Study of Income Dynamics (PSID) of the United States to analyse the differences between money and extended incomes of urban and rural white, married-couple households, husband employed. They use the opportunity cost approach. Their findings included:

1. Household production raised the family's average access to goods and services in aftertax figures by a range of $76-101 \%$ of the average family's money income.

2. Gini ratios based on money incomes only indicated that income distribution showed higher inequality than income distribution based on extended incomes, so after having added the value of household production. In rural households distribution of money income turned out to be more unequal than in urban households. If the value of household production had been added, the inequality in income distribution was more substantial in urban households. Bryant and Zick remarked that this suggested that poor rural households made greater use of household production to increase their access to goods and services than their urban counterparts.

3. The market earnings of married women made crucial contributions to money income and had an equalizing effect on income distribution. But the value of household production turned out to have an even greater equalizing effect, especially in rural households.

In a study of Hagenaars, Homan and Van Praag (1984) the subjective evaluation of one- and two-earners with the same net money incomes has been compared. Their research shows that the main breadwinner does 6 hours per week household work, the wives in one-earner families do 51 hours and the wives in two-earner families 38 hours. The net incomes of one-earners were evaluated $30 \%$ higher than the same net incomes of two-earners. In other words the higher household production of one-earners was estimated at $30 \%$ of net money incomes of one-earners (Hagenaars, Homan and Van Praag 1984). 
The main objective of a study by Homan (Homan 1988) was to quantify the amount of home production disaggregated to the micro level of households. Homan particularly focussed on differences between one-earner and two-earner families.

He estimated the value of household production by using the time data of oneand two-earner families, which he selected from a sample of 12000 households in 1983. He estimated the market cost of a substitute for household production at Dfl.10 per hour. Homan found that the monetary value of household production varies with the number and age of children and the hours the wife spends on the labour market. He corrected household incomes by using family equivalence scales of the Van Praag method (Van Praag 1968, 1971). This method compares household incomes which give households levels of subjective well-being. After this correction, inclusion of household production increased the average one-earner's income by a factor 1.8 and the average two-earners' income by a factor 1.3 (Homan 1988 p.183 and 185). He used the Variance of the logarithm of incomes as a measure of income inequality. He found that income inequality between one- and two-earners had been reduced by $71 \%$ if household production was added to net money income, corrected for family size. In this way the difference in money income between one- and two-earner families had nearly been compensated for by the difference in household production (Homan 1988 p.187).

The same author repeated his study in 1991. In the 1991 study two waves of the same panel of households were asked to mention net money income of the main breadwinner and his partner, and the number of paid and unpaid hours per week of both partners. The sample included households of single people, single parents, one-earners and two-earners. Homan used a market cost method and made corrections for family size by using equivalence scales. His conclusions from this study were following:

1. Extended incomes for all households were $42 \%$ higher than money incomes after a correction for household size.

2. Single people with a job, two-earners without children and self-employed people had relatively little household production. Single parents without a job and one-earners increased their welfare most by household production.

3. Differences in money incomes were bigger than differences in extended incomes: the highest money income was 2.55 times higher than the lowest money income (money income of two-earners with two jobs and that of a single parent without a job); the highest extended income was 2.16 times higher than the lowest extended income (two-earners with two jobs and single people without a job).

4. Household production was a compensation for the differences in money income between one-earner and two-earner families. The money income of two-earners without children was $38 \%$ higher than the money income of the ditto one-earner, but the difference between their extended incomes was only $16 \%$. The money income of two-earners with children was $32 \%$ higher than the money income of the ditto one-earner, but the difference between their 
Bonke (1992) included household production into extended incomes for couples out of a sample 5000 Danish adults in a 1987 time use survey. For employed wives he used their market wages, for non-employed wives an estimated "reservation wage", which was higher than the wage rates for women. Household production contributed $38 \%$ to average gross income and $48 \%$ to average aftertax income. This average income consisted of labour income of both partners, capital income and public transfers. Income inequality showed a $14 \%$ reduction after adding household production, using the Variance to logarithmen of net income. Income inequality showed a $17 \%$ reduction by using the Gini ratio (Bonke 1992 p.289 and 290).

Aslaksen and Koren (1993) estimates the value of household production of Norwegian couples, single people and one-parent families based on a. 1990 time use survey and on the wages of a home help. They disregarded the household contribution of children and other members of the household. Average individual aftertax income was doubled by adding the value of household work The Gini coefficient of aftertax income of all households was reduced by $22.1 \%$ by adding the value of household work (Aslaksen and Koren 1993 tables 5 and 6).

\subsection{Unpaid work in the 1985 and 1990 Dutch income distributions}

\subsubsection{Data and method}

For this part of the study micro-data of the 1985 and 1990 Intomart time use studies have been used, which data are now in the Steinmetz. Archief. These two years have been chosen because the volume of paid and unpaid work changed significantly in this period. The hypothesis was that this change could also be seen in income distribution. The samples consisted of more than 3000 cases. All cases were weighted according to number of persons in the household, sex, age, urbanity and main occupation (Knulst and Van Beek 1990 p.163). Respondents registered their activities during a week in autumn in a precoded diary. Before and after filling in the diary interviews were held. Questions included the number of persons, sex and age of other members of the household and the relationship of the respondent to other members of the household. Respondents were also questioned about their paid work and the paid work of the other members of the household. One of the last questions in the second interview concerned net household income per month. For this item the answers of about 2250 respondents could be used. A subdivision was made into 4 household types:

- single people

- couples with one-earner

(respondent breadwinner or partner of breadwinner)

- couples with two-earners

(respondent main breadwinner or partner of main breadwinner)

- one-parent families 
The time use of the respondents was registered in the diary, the time use of other members of the household was not registered. Respondents consisted of breadwinners, partners and other members of the household. The average time use of all respondents was calculated according to sex, household type and age group. This average time use was accounted to members of the family other than the respondents. The average time use of other members of the household was added to the individual time use of the respondent. In this way total unpaid hours of work of the complete household was counted and valued at net legal minimum wage. The value of unpaid work per household was added to net household income in order to obtain total income of paid and unpaid time. The data of one-earner couples consisted of answers given by the breadwinner, the partner of the breadwinner or another member of the family, for example a child. The answers of all respondents in one-earner families in the sample were taken together for the estimation of family income inclusive of unpaid work. The data of two-earner couples consisted of answers given by the main breadwinner, the partner of the main breadwinner or another member of the family. The data of one-parent families consisted of answers given by the parent or another member of the family.

Table 6.2. gives an overview of the respondents. The traditional family of male breadwinner and dependent female partner dominates: in the 1985 sample as well as in the 1990 sample more than 1000 of the 2250 respondents belong to this type of household.

The traditional role also dominated the 550 two-earner families: in about 400 households the main breadwinner is the husband. One-parent families were scarce: less than 100 respondents belonged to this household type. More women than men were single. 
Table 6.2 .

Respondents per household type (1985 and 1990)

\begin{tabular}{|c|c|c|c|}
\hline Household type & Position of respondent & 1985 & 1990 \\
\hline \multirow[t]{6}{*}{ One-earner } & Male breadwinner & 590 & 543 \\
\hline & Female breadwinner & 17 & 29 \\
\hline & Partner of male breadwinner & 514 & 434 \\
\hline & Partner of female breadwinner & 14 & 7 \\
\hline & Male family member & 109 & 108 \\
\hline & Female family member & 70 & 49 \\
\hline All one-earner families & & 1314 & 1170 \\
\hline \multirow[t]{6}{*}{ Two-earners } & Main breadwinner - male & 224 & 251 \\
\hline & Main breadwinner - female & 6 & 19 \\
\hline & Partner of male breadwinner & 186 & 204 \\
\hline & Partner of female breadwinner & 7 & 5 \\
\hline & Male family member & 69 & 42 \\
\hline & Female family member & 61 & 31 \\
\hline All two-earner families & & 553 & 552 \\
\hline \multirow[t]{4}{*}{ One-parent } & Male parent & 5 & 4 \\
\hline & Female parent & 38 & 49 \\
\hline & Male family member & 26 & 22 \\
\hline & Female family member & 15 & 21 \\
\hline All one-parent families & & 84 & 96 \\
\hline \multirow[t]{2}{*}{ Single people household } & Male & 104 & 173 \\
\hline & Female & 203 & 268 \\
\hline \multicolumn{2}{|c|}{ All single people households } & 307 & 441 \\
\hline \multicolumn{2}{|l|}{ All respondents } & 2258 & 2259 \\
\hline
\end{tabular}

Source: Micro data of Steinmetz Archief

\subsubsection{Results}

\subsubsection{Income per household type}

In the tables in this section the respondents have been ranged under the household type they belong to. In table 6.3. allowance is made for the number of persons in the household or economies of scale. Household income has been corrected by using the OECD-equivalence scale. The weight of the first adult is 1.0, other adults count for 0.7 , children under 17 years of age count for 0.5 . The income of a single person is divided by 1.0, the income of a household of two adults by 1.7 to obtain the income per family equivalence. For the calculations of extended incomes the minimum wages have been chosen. The subgroups female headed two-earner families and male headed one-parent families are too limited to draw any conclusions. 
Table 6.3., column B, shows that in 1985 net money incomes were lowest for the subgroup single people (Dfl. 1642) and highest for the subgroup two-earner households (Dfl. 3160). Net money incomes of the subgroup one-parent families (Dfl. 2369) were only slightly lower than net incomes of one-earners (Dfl. 2480). However, in these subgroups there is a difference between males and females. Of all households, the single female has the lowest income whereas the income of two-earner female-headed household is highest.

Household income inclusive of the value of unpaid work calculated at the minimum wages (column C) were also lowest for single people (Dfl. 2656) and highest for two-earner households (Dfl. 5436). One-parent families (Dfl. 4748) and one-earners (Dfl. 5252) were in between. Single males had the lowest income after correction for unpaid work, the female two-parent household had the highest (column C).

In one-earner households one partner works full-time in the household. So one would expect household income of one-earners to increase most by unpaid work. Column $C$ shows that this is true: household incomes of the subgroup one-earners more than doubled by the value of unpaid work (column C/B). Average net money income of two-earners, as shown in column B, was $27 \%$ higher than average net money income of one-earners. The difference between two-earners and one-earners decreased to $3 \%$ if unpaid work was added (column C). If corrected for family size the difference in incomes between two-earners and one-earners was $6 \%$ (columns D and $\mathrm{E}$ ).

The subgroup one-parent families doubled their income by unpaid work mainly due to female one-parent families. Single males were least productive in unpaid work: their incomes only increased by a factor 1.4. Male partners of female one-eamers also contributed less to extended incomes than female partners. The same conclusion could be drawn for male partners of two-earners where females are the main breadwinners.

Looking at the extended incomes corrected for family size (column E), income of the single female is highest and income of the female headed one-parent family is lowest.

Obviously women, compared to men, attach more importance to a well kept household and well cared for family. Men attach great value to other activities, they tolerate more dirt, they accept an untidier house. I came to the conclusion that welfare is partly sex determined: unpaid work contributes more to female welfare, leisure more to male welfare. 
Table 6.3.

Average net money income per month in Dutch guilders in 1985 per household type, exclusive and inclusive of the value of unpaid work at 1985 legal minimum wages

\begin{tabular}{|c|c|c|c|c|c|c|}
\hline & $\begin{array}{l}\mathrm{A} \\
\mathrm{N}\end{array}$ & $\begin{array}{l}\text { B } \\
\text { Net } \\
\text { money } \\
\text { income }\end{array}$ & $\begin{array}{l}\text { C } \\
\text { Inclusive } \\
\text { unpaid } \\
\text { work at } \\
\text { minimum } \\
\text { wages }\end{array}$ & $\mathrm{C} / \mathrm{B}$ & $\begin{array}{l}\text { D } \\
\text { Net money } \\
\text { income } \\
\text { per family } \\
\text { equivalence }\end{array}$ & $\begin{array}{l}\text { E } \\
\text { Inclusive } \\
\text { unpaid } \\
\text { work at } \\
\text { minimum } \\
\text { wages }\end{array}$ \\
\hline One-earners & 1314 & 2480 & 5252 & 2.1 & 1064 & 2228 \\
\hline - male & 1278 & 2470 & 5257 & 2.1 & 1058 & 2226 \\
\hline - female & 36 & 2855 & 5101 & 1.8 & 1268 & 2314 \\
\hline Two-earners & 553 & 3160 & 5436 & 1.7 & 1348 & 2361 \\
\hline - main breadwinner male & 535 & 3145 & 5437 & 1.7 & 1338 & 2359 \\
\hline - main breadwinner female & 18 & 3588 & 5382 & 1.5 & 1642 & 2414 \\
\hline One-parent & 84 & 2369 & 4748 & 2.0 & 1108 & 2210 \\
\hline - male & 19 & 3168 & 5541 & 1.7 & 1409 & 2397 \\
\hline - female & 65 & 2136 & 4516 & 2.1 & 1020 & 2155 \\
\hline Single & 307 & 1642 & 2656 & 1.6 & 1642 & 2656 \\
\hline - male & 104 & 1770 & 2494 & 1.4 & 1770 & 2494 \\
\hline - female & 203 & 1576 & 2739 & 1.7 & 1576 & 2739 \\
\hline
\end{tabular}

(Own calculations based on 1985 Intomart time use study)

Table 6.4. shows the 1990 income data based on the Intomart time use studies. The analysis has been extended: a distinction is made for families with and without children.

Table 6.4. column B shows that in 1990, as well as in 1985, money income was lowest for the subgroup of single people and highest for two-earner households. The difference in money incomes between the households of one-parent families and one-earners was considerably higher in 1990 than it was in 1985. Column C shows that if the value of unpaid work was added to money income, single people had the lowest income (Dfl. 2781) and the subgroup one-earners had the highest income, whereas in 1985 the two-earners had the lead. Looking at the extended incomes corrected for family size in 1990 (column E), welfare of the male two-earner without children was highest and welfare of the female headed one-parent family was lowest.

Money income of two-earners without children is $35 \%$ higher than that of ciitc one-earners, but after adding the value of unpaid work the difference is only $2 \%$. Money income of two-earners with children is $17 \%$. higher than that of ditto oneearners but after adding the value of unpaid work it is $3 \%$ lower. So the value of 
unpaid work nearly wipes out the income differences between one-earners and two-earners.

Table 6.4.

Average net money income per month in Dutch guilders in 1990 per household type, exclusive and inclusive of the value of unpaid. work at 1990 legal minimum wages.

\begin{tabular}{|c|c|c|c|c|c|c|}
\hline & $\begin{array}{l}\mathrm{A} \\
\mathrm{N}\end{array}$ & $\begin{array}{l}\text { B } \\
\text { Net } \\
\text { money } \\
\text { income }\end{array}$ & $\begin{array}{l}\text { C } \\
\text { Inclusive } \\
\text { unpaid } \\
\text { work at } \\
\text { minimum } \\
\text { wages }\end{array}$ & $\mathrm{C} / \mathrm{B}$ & $\begin{array}{l}\text { D } \\
\text { Net money } \\
\text { income } \\
\text { per family } \\
\text { equivalence }\end{array}$ & $\begin{array}{l}\mathrm{E} \\
\text { Inclusive } \\
\text { unpaid } \\
\text { work at } \\
\text { minimum } \\
\text { wages }\end{array}$ \\
\hline One-earners without children & 375 & 2706 & 5254 & 1.9 & 1591 & 3093 \\
\hline - male & 352 & 2710 & 5313 & 2.0 & 1594 & 3128 \\
\hline - femaie & 23 & 2635 & 4354 & 1.7 & 1550 & 2561 \\
\hline Two-earners without children & 175 & 3652 & 5336 & 1.5 & 2148 & 3139 \\
\hline - main breadwinner male & 158 & 3687 & 5384 & 1.5 & 2.169 & 3167 \\
\hline - main breadwinner female & 17 & 3321 & 4895 & 1.5 & 1953 & 2879 \\
\hline One-earners with children & 794 & 3062 & 6408 & 2.1 & 1081 & 2200 \\
\hline - male & 781 & 3057 & 6395 & 2.1 & 1081 & 2197 \\
\hline - female & 13 & 3383 & 7232 & 2.1 & 1118 & 2407 \\
\hline Two-earners with children & 378 & 3590 & 6228 & 1.7 & 1296 & 2232 \\
\hline - main breadwinner male & 370 & 3590 & 6240 & 1.7 & 1292 & 2230 \\
\hline - main breadwinner female & 7 & 3593 & 5630 & 1.6 & 1480 & 2314 \\
\hline One-parent & 97 & 1877 & 3780 & 2.0 & 1051 & 2090 \\
\hline - male & 9 & 2823 & 4442 & 1.6 & 1672 & 2642 \\
\hline - female & 88 & 1782 & 3713 & 2.1 & 988 & 2034 \\
\hline Single & 441 & 1771 & 2781 & 1.6 & 1771 & 2781 \\
\hline - male & 173 & 1919 & 2657 & 1.4 & 1919 & 2567 \\
\hline - female & 268 & 1675 & 2860 & 1.7 & 1675 & 2860 \\
\hline
\end{tabular}

(Own calculations based on 1990 Intomart time use study)

Table 4.1. showed that on average the volume of paid work increased between 1985 and 1990, whereas the volume of unpaid work decreased. This can also be seen in tables 6.3. and 6.4. Money incomes increased more than extended incomes. Money income of the one-earner households rose for example by $19 \%$, income inclusive of the value of unpaid work by $15 \%$. However, one should bear in mind that the data considered were not longitudinal, the size of several subgroups changed because labour market participation of women rose and last but not least because the subgroup one-parent families was rather small to draw any conclusions. 
In section 6.3. equivalence scales of the OECD and SN (Schiepers) have been described. In the $\mathrm{SN}$-scale net money income has been corrected by different equivalence scales for one- and two-earners by looking at the extra costs caused by the participation of both partners in the labour market. In the OECD-scale no distinction is made between one- and two-earners. In tables 6.3. and 6.4. however a distinction is made on the income-side between one- and two-earners in columns $\mathrm{C}$ and $\mathrm{E}$ because one-earners have, ceteris paribus, a larger household production. What is the relationship between both methods if there is any? The Schiepers method assumes that extra expenses of two-earners compared to oneearners are a criterion for the difference in welfare, if welfare is to be measured by net money income. In my opinion this assumption is not right for two reasons.

1. Child care is an important issue for two-earners. In the Netherlands subsidized child care is available for less than $5 \%$ of all children aged $0-3$ years. The waiting list is almost as long as the list of participating children (Arachne 19.12.1994). Therefore nearly half of the children of Dutch working women are cared for by other family members or other unpaid caretakers (Maassen van den Brink et al. 1995 p 38). Unpaid child care does not show in expenses, but it can be considered as a gift from the caretaker. The same applies to other informal help and care. In my opinion such gifts should be left out in welfare comparisons because one cannot be certain that it will be continued as there is no binding (legal) agreement.

2. In two-earner farnilies some jobs are not done at all: two-earner families with children spend 17 to 20 hours a week less on unpaid work than one-earner families (Ministry of Social Affairs 1995, p.198). The two-earner family with few hours left for cleaning may decide to leave window-cleaning to nature, instead of hiring a window-cleaner. Compared to a one-earner family with enough time for cleaning, the consumption level of the two-earner family is, ceteris paribus, lower. Differences like this one do not show in the Schiepers' budget method.

Therefore I think that a welfare comparison method based on comparing extended incomes corrected by means of the OECD-scale is a better indication than the one based on comparing net money incomes corrected by means of the $\mathrm{SN}$ scales. Nevertheless it is interesting to compare the results of both methods as is done in table 6.5. Net money income corrected by means of the Schiepers-scale is given in column 1, extended income corrected by means of the OECD-scale is given in column 2 (Column 2 is almost identical to column $\mathrm{E}$ in table 6.4.) 
Table 6.5.

Difference in income between household types following different methods (year 1990)

\begin{tabular}{lcc}
\hline & $\begin{array}{l}\text { Net money } \\
\text { income per } \\
\text { SN family } \\
\text { equivalence }\end{array}$ & $\begin{array}{l}\text { Extended income } \\
\text { per OECD family } \\
\text { equivalence }\end{array}$ \\
\hline $\begin{array}{l}\text { One-earner without children } \\
\text { Two-earner without children }\end{array}$ & 1950 & 3093 \\
One-earner with children & 2543 & 3139 \\
Two-earner with children & 1615 & 2200 \\
One-parent & 1858 & 2232 \\
Single people & 1296 & 2090 \\
- all & 1771 & 2781 \\
- male & 1919 & 2567 \\
- female & 1675 & 2860 \\
\hline
\end{tabular}

(Own calculations based on 1990 Intomart time use study)

Comparing the two columns of table 6.5. extended income per OECD family equivalence scale is 1.2 to 1.7 higher than net money income per $\mathrm{SN}$ family equivalence scale. The difference between the two columns is a reflection of the different family equivalence scales and of the difference between money income and extended income. As could be expected, the differences between the two columns are greatest for the categories with high household production: single females, one-earners without children and female headed one-parent families.

Table 6.6. shows the ratio between the incomes of one-earners and other households. The differences between one-earners and other households are smaller in the money-SN-method (column 1) than in the extended-OECDmethod (column 2). Both methods only show minor differences when comparing the corrected incomes of one-earners versus single people and oneearners without children versus one-parent families. The explanation is that the difference in scales is smallest for these categories of households (see table 6.1.). The difference between both methods is greatest when comparing the income of one-earners without children versus two-earners without children and oneearners without children versus two-earners with children. This is due to the high household production of one-earners. Table 6.6. confirms my opinion that the extended-OECD-method is to be preferred. 
Table 6.6.

Ratio between one-earners and other households in the money-SN-method and in the extended-OECD-method.

money-SN extended-OECD

One-earner without children

Two-earners without children

$\begin{array}{ll}0.767 & 0.985\end{array}$

One-earner with children

Two-earners with children

$\begin{array}{ll}0.869 & 0.986\end{array}$

One-earner without children

Single person

One-earner without children

Single parent

\subsubsection{Income per household type and age group}

In tables 6.7. and 6.8. average household incomes have been subdivided according to age groups. The number of cases in these tables was rather small to allow a subdivision into age groups. Therefore conclusions should be made carefully. Age did not have much influence on the contribution of unpaid work to extended incomes: for one-earners the importance of unpaid work increased until they are 35 years of age, that is the period they are raising young children. After that period the contribution of unpaid work to extended income decreased slightly in 1985, to increase again slightly in 1990.

For two-earners unpaid work becomes more important with age. The subgroup of one-parent families was rather small to draw any conclusions. For one-parent families and for one-earners the value of unpaid work was equally important: they doubled their income by doing unpaid work. There was no clear relation between the contribution of unpaid work and age.

For single people the contribution of unpaid work to extended incomes increased with age, although the contribution was smaller than for other household types. For the rest the same picture emerged as in table 6.3.: household incomes of oneeamers and one-parent families doubled if unpaid work valued at the minimum wages was added. Household incomes of two-earners increased by a factor of about 1.7. The incomes of single people increased by a factor of about 1.5. Single females' incomes increased more than the single males' incomes. 
Table 6.7.

Average net household income per month in 1985 per household type and age group in. Dfl.

\begin{tabular}{|c|c|c|c|c|c|c|}
\hline Age group & $12-18$ & $19-24$ & $25-34$ & $35-49$ & $50-64$ & $65>$ \\
\hline \multicolumn{7}{|l|}{ One-eamers } \\
\hline $\mathrm{N}=$ & 3 & 35 & 255 & 451 & 355 & 210 \\
\hline exclusive unpaid work & 1782 & 1850 & 2200 & 2631 & 2687 & 2294 \\
\hline inclusive unpaid work & 3434 & 4161 & 4800 & 5570 & 5635 & 4686 \\
\hline inclusive/exclusive & 1.9 & 2.2 & 2.2 & 2.1 & 2.1 & 2.0 \\
\hline \multicolumn{7}{|l|}{ Two-earners: } \\
\hline$N=$ & - & 42 & 153 & 281 & 75 & - \\
\hline exclusive unpaid work & - & 2973. & 3029 & 3236 & 3254 & - \\
\hline inclusive unpaid work & - & 4442 & 4825 & 5773 & 5979 & - \\
\hline inclusive / exclusive & - & 1.5 & 1.6 & 1.8 & 1.8 & - \\
\hline \multicolumn{7}{|l|}{ One-parent families } \\
\hline $\mathrm{N}=$ & - & 2 & 17 & 33 & 21 & 14 \\
\hline exclusive unpaid work & - & 3013 & 1674 & 2021 & 2728 & 3557 \\
\hline inclusive unpaid work & - & 4420 & 3347 & 4020 & 5703 & 6893 \\
\hline inclusive / exclusive & - & 1.5 & 2.0 & 2.0 & 2.1 & 1.9 \\
\hline \multicolumn{7}{|l|}{ Single people } \\
\hline$N=$ & 1 & 29 & 57 & 30 & 47 & 143 \\
\hline exclusive unpaid work & 750 & 1141 & 1626 & 1888 & 1817 & 1646 \\
\hline inclusive unpaid work. & 918 & 1722 & 2268 & 2718 & 3060 & 2451 \\
\hline inclusive / exclusive & 1.2 & 1.5 & 1.4 & 1.4 & 1.7 & 1.5 \\
\hline
\end{tabular}

(Own calculations based on a 1985 Intomart time use study)

Table 6.8 .

Average net household income per month in 1990 per household type and age group in Dfl.

\begin{tabular}{|c|c|c|c|c|c|c|}
\hline Age group & $12-18$ & $19-24$ & $25-34$ & $35-49$ & $50-64 k$ & $65>$ \\
\hline \multicolumn{7}{|l|}{ One-earners } \\
\hline$N=$ & 0 & 27 & 184 & 412 & 339 & 207 \\
\hline exclusive unpaid work & 0 & 2196 & 2605 & 3107 & 3150 & 2698 \\
\hline inclusive unpaid work & 0 & 3981 & 5424 & 6310 & 6491 & 5555 \\
\hline inclusive / exclusive & 0 & 1.8 & 2.1 & 2.0 & 2.1 & 2.1 \\
\hline \multicolumn{7}{|l|}{ Two-eamers } \\
\hline $\mathrm{N}=$ & 0 & 16 & 169 & 255 & 106 & 6 \\
\hline exclusive unaid work & 0 & 3102 & 3389 & 3750 & 3778 & 2227 \\
\hline inclusive unpaid work & 0 & 4531 & 5237 & 6359 & 6398 & 4064 \\
\hline inclusive / exclusive & 0 & 1.5 & 1.6 & 1.7 & 1.7 & 1.8 \\
\hline \multicolumn{7}{|l|}{ One-parent families } \\
\hline$N=$ & 0 & 4 & 22 & 44 & 19 & 7 \\
\hline exclusive unpaid work & 0 & 1371 & 1474 & 1880 & 2049 & 2943 \\
\hline inclusive unpaid work & 0 & 2965 & 3279 & 3682. & 3949 & 5999 \\
\hline inclusive /exclusive & 0 & 2.2 & 2.2 & 2.0 & 1.9 & 2.0 \\
\hline \multicolumn{7}{|l|}{ Single people } \\
\hline $\mathrm{N}=$ & 1 & 83 & 102 & 47 & 74 & 134 \\
\hline exclusive unpaid work & 1000 & 1322 & 1940 & 2191 & 1750 & 1792 \\
\hline inclusive unpaid work & 1492 & 1906 & 2593 & 2953 & 3121 & 3225 \\
\hline inclusive / exclusive & 1.5 & 1.4 & 1.3 & 1.4 & 1.8 & 1.8 \\
\hline
\end{tabular}

(Own calculations based on a 1990 Intomart time use study) 


\subsubsection{Income inequality}

What is the influence on income inequality if the value of unpaid work is added? To measure income inequality the Theil method has been chosen. Odink (1985) considers the Theil coefficient to be a reliable, homogene, symmetrical measure which could easily be decomposeci into a weighted inequality within income subgroups and into weighted inequality between income subgroups (Odink 1985 p.22-35). As explained in section 6.1. the Theil coefficient is written as:

$T=\Sigma_{i}\left(X_{i} / Y\right) \ln \left(X_{i} N / Y\right)$

with $\Sigma_{i} X_{i}=Y$

T can be written as:

$$
\begin{aligned}
T & =\Sigma_{i} \Sigma_{i}\left(Y_{i j} / Y\right) \ln \left(Y_{i j} N / Y\right) \\
& =\Sigma_{i} \Sigma_{j}\left(Y_{i j} / Y_{i}\right)\left(Y_{i} / Y\right)\left(\ln \left(N_{i} Y_{i j} / Y_{i}\right)+\ln \left(N Y_{i} / N_{i} Y\right)\right) \\
& =\Sigma_{i} \Sigma_{j}\left(Y_{i j} / Y_{i}\right)\left(Y_{i} / Y\right) \ln \left(N_{i} Y_{i j} / Y_{i}\right)+\Sigma_{i}\left(Y_{i} / Y\right) \ln \left(\left(N / N_{i}\right)\left(Y_{i} / Y\right)\right) \\
& =\Sigma_{i} y_{i} T_{i}+\Sigma_{i} y_{i} \ln \left(y_{i} / n_{i}\right)
\end{aligned}
$$

where: $\Sigma_{\mathrm{i}} \mathrm{y}_{\mathrm{i}} \mathrm{T}_{\mathrm{i}}$

is the weighted measure of inequality within income subgroups and

$\Sigma_{\mathrm{i}} \mathrm{y}_{\mathrm{i}} \ln \left(\mathrm{y}_{\mathrm{i}} / \mathrm{n}_{\mathrm{i}}\right)$

measures the inequality between income subgroups.

\begin{tabular}{|c|c|c|c|c|c|c|c|c|}
\hline \multirow[b]{2}{*}{$\begin{array}{l}\text { Respondent belongs } \\
\text { to household type: }\end{array}$} & \multicolumn{4}{|c|}{1985} & \multicolumn{4}{|l|}{1990} \\
\hline & $N$ & A & B & $\begin{array}{l}1-(B / A) \\
\times 100\end{array}$ & $\mathrm{~N}$ & A & B & $\begin{array}{l}1-(B / A) \\
\times 100\end{array}$ \\
\hline One-earners & 1314 & 0.094 & 0.035 & 62.6 & 1169 & 0.112 & 0.048 & 57.0 \\
\hline Two-eauners & 553 & 0.086 & 0.036 & 58.2 & 553 & 0.092 & 0.043 & 52.7 \\
\hline Single people & 307 & 0.078 & 0.046 & 40.9 & 441 & 0.100 & 0.060 & 36.60 \\
\hline One-parent families & 84 & 0.109 & 0.047 & 57.0 & 97 & 0.134 & 0.055 & 58.90 \\
\hline Total & 2258 & 0.103 & 0.039 & 61.9 & 2260 & 0.117 & 0.052 & 55.84 \\
\hline
\end{tabular}

Table 6.9.

Theil coefficients of net money income per family equivalence factor (A) and income inclusive of the value of unpaid work per fanily equivalence factor at legal minimum wages(B)

(Own calculations based on 1985 and 1990 Intomart time use studies) 
In table 6.9. column A shows the Theil coefficient of net money household income per family equivalence in 1985 and 1990. Column B shows net household money income inclusive of the value of unpaid work per family equivalence at minimum wages.

If all households would have equal incomes, the Theil coefficient $=0$, there is no inequality. The closer the Theil coefficient is to zero, the smaller the inequality. Column A shows that income inequality of net money incomes in 1985 was smallest among single people and two-earners. Income inequality was greatest among one-parent families and one-earners. In 1990 inequality was smallest among two-earners and greatest among one-parent families.

If the value of unpaid work was added to net incomes the reduction of income inequality was $61.9 \%$ in 1985 and $55.8 \%$ in 1990 . The reduction in income inequality was higher in 1985 because more unpaid work was done.

In 1985 the reduction of income inequality was highest for one-earners $(62.6 \%)$ because the value of unpaid work was added, followed by two-earners, one-parent families and single people. In 1990 this order had changed: the reduction in income inequality was highest for one-parent families $(58.9 \%)$, followed by one-earners, two-earners and single people.

Tables 6.3. and 6.4. showed that in the period 1985-1990 money incomes of one-earners rose most, followed by two-earners and single people, whereas money incomes of one-parent families decreased. In this way the importance of unpaid work became relatively smaller for one-earners, whereas it became more important for one-parent families. Consequently they changed places in the reduction of income inequality.

Table 6.10. shows the decomposition of the Theil coefficient in coefficients for inequality within groups of household types and between those groups. The contribution of inequality within household groups is more substantial than the contribution of inequality between groups. The same conclusion has been drawn by Homan (1988 p.185) and Bonke (1992 p.291).

Table 6.10.

Contribution of income inequality within household types and between household types to total income inequality as measured by Theil coefficients of net money income corrected for number of persons $(A)$, plus unpaid work at legal minimum wages $(B)$

\begin{tabular}{|c|c|c|c|}
\hline & & A & B \\
\hline $\begin{array}{l}\text { Theil coefficient } \\
\text { within household types: }\end{array}$ & $\begin{array}{l}1985 \\
1990\end{array}$ & $\begin{array}{l}0.0898=86.6 \% \\
0.1041=89.3 \%\end{array}$ & $\begin{array}{l}0.0376=95.2 \% \\
0.0498=96.7 \%\end{array}$ \\
\hline $\begin{array}{l}\text { Theil coefficient } \\
\text { between household types: }\end{array}$ & $\begin{array}{l}1985 \\
1990\end{array}$ & $\begin{array}{l}0.0138=13.3 \% \\
0.0125=10.7 \%\end{array}$ & $\begin{array}{l}0.0019=4.8 \% \\
0.0017=3.3 \%\end{array}$ \\
\hline Total Theil & $\begin{array}{l}1985 \\
1990\end{array}$ & $\begin{array}{l}0.1036=100 \% \\
0.1166=100 \%\end{array}$ & $\begin{array}{l}0.0395=100 \% \\
0.0515=100 \%\end{array}$ \\
\hline
\end{tabular}


Column A shows that total income inequality of corrected net incomes can be attributed to income inequality inside groups of household types for $87 \%$ to $89 \%$ and to inequality between groups of household types for $11 \%$ to $13 \%$. Column B shows that in 1985 income inequality diminished from 0.1036 to 0.0395 , that means $62 \%$, if unpaid work at minimum wages is added to money income. Of the remaining income inequality $95 \%$ can be attributed to inequality within groups of household types and $5 \%$ to inequality between groups of household types.

In 1990 income inequality diminished from 0.1166 to 0.05151 , that means $56 \%$, if unpaid work at minimum wages is added to money income. Of the remaining income inequality $97 \%$ can be attributed to inequality within groups of household types and $3 \%$ to inequality between groups of household types.

It can be concluded that in 1990 income inequality remained greater after adding the value of unpaid work because income inequality was less reduced in 1990 compared to 1985 after having addled the value of unpaid work to money income. The role of unpaid work has become less prominent in the period 1985-1990 thus reducing inconne inequality. This could be due to higher unemployment in 1985 compared to 1990: in $198512.9 \%$ of the economically active population was registered as unemployed, in 1990 this percentage was $5.9 \%$.(16). In 1990 the total Theil coefficient of money income was $12.5 \%$ higher than it was in 1985, whereas the total Theil of extended income in 1990 was $30 \%$ higher than it was 1990 . By adding unpaid work the gap in income inequality was narrowed more in 1985 than it was in 1990.

If any differences in inequality remain between one- and two-earners after corrections for family size, these differences are mainly caused by demographic or cultural differences in the own group of households and not by differences in labour market status between groups of household types.

\subsection{Summary and conclusion}

Research by Bryant and Zick, by Homan, by Bonke and by Aslaksen and Koren and by myself show that differences in money incomes between households are bigger than differences in extended incomes in which the value of unpaid work has been included. The value of household production turns out to be substantial: $40 \%$ to more than $100 \%$ of money incomes, depending on the data and the methods used.

Single males and two-earners without children have relatively little household production. Single parents without a job and one-earners increase their welfare most by unpaid work.

\footnotetext{
16 The definition of economically active population changed between 1985 and 1990. In 1985 people were counted as economically active if they worked or were willing to work at least 20 hours a week. In 199012 hours work a week was the criterion. This may partly explain the lower unemployment rate in 1990.
} 
Household production turns out to be a great equalizer: differences in money incomes between two-earner households and one-earner households are nearly wiped out if the value of unpaid work at minimum wages is added to money income. Income inequality within groups of household types is greater than between groups of household types.

Women contribute more to household production than men, even if they are single. Female partners in one-earner and two-earner households contribute more to money income by doing unpaid work, than male partners in female headed one-earner and two-earner households. The female one-parent: increases her extended income more than her male counterpart.

Money incomes as well as extended incomes increased between 1985 and 1990 for one-earners, two-earners and single people. In the same period money income as well as extended incomes decreased for one-parent families.

The role of unpaid work in reducing income inequality has become less prominent: money incomes increased more than exterided incomes in the period 1985-1990. In 1985 income inequality was reduced by $62 \%$ after adding the value of unpaid work to money income. In 1990 this reduction was only $56 \%$. 


\section{UNPAID WORK IN ECONOMIC MODELS}

"Models will improve because better theories and more data become available" Jan Tinbergen 1983)

\subsection{Introduction}

In this chapter structure, scope and shortcomings of macroeconomic models are described in section 2 . In section 3 literature of models which pay attention to gender are presented. In section 4 Plantenga and Sloep criticise the household sector of the MIMIC-model of the Netherlands Central Planning Bureau because unpaid work is absent. In section 5 research is presented which strengenths this criticism. In section 6 it is suggested to implement unpaid work in macroeconomic models not only in the household block but also in the production and consumption function. The feedbacks between paid and unpaid work are traced. Summary and conclusion are given in section 7 .

\subsection{Structure and scope of macroeconomic models}

A model is a simplified reflection of part of reality. It can be a way to remember things, e.g. a picture, which can help to get a first impression of an object, a scalemodel of a building, which may serve as a means to gather experimental data, or the behaviour of a model plane in a windtunnel. Often it is possible to present an object, a process or a system by a set of mathematical equations (Böttcher 1988).

An economic model tries to reflect the economic aspect of (part of) reality by means of a set of mathematical equations. The intention of a macroeconomic model is to reflect the relations between compilations of economic quantities such as families, firms and governments.

Policy making discipline is promoted by using a model. Politicians are obliged to make consistent promises, because they have to quantify policy programmes. The effects of programmes of political parties are calculated with the help of a model. Economic models can warn policy makers that negative developments may occur, e.g. inflation or unemployment (Zalm 1988).

With the help of economic models prognoses and scenarios can be made, such as the Macro Economical Prognosis of the Netherlands Central Planning Bureau (MEV), which is published every year at the same time as the annual Government budget. The MEV is looking a year ahead. The CPB also publishes scenarios, looking ahead 4 to 5 years or even longer, e.g "Nederland in drievoud" (The Netherlands in triplicate), which presents three growth scenarios of the Dutch economy until the year 2015. 
In short: it is clear that a macroeconomic model can play an important role in supporting economic policies: the effects of a change in taxation, of economizing on government expenditures, and of changes in social security system, can be simulated and more seriously considered (Zalm 1988).

Models can also be deceiving or meaningless, because a model attaches little economic consequences to certain decisions or time-lags occur which are not taken into account by the model. An example is to collect taxes earlier in the year, which looks like an improvement in tax revenues and a smaller deficiency of Government budget in a certain year (Zalm 1988).

The way a model is stylized can also be a source of disappointment. In the mathemetical equations of the model one finds all kinds of parameters and coefficients, which represent human behaviour. These coefficients and parameters are often based. on statistical time series. Using time series implies that human behaviour does not change in the course of time, which seems unlikely (Van der Geest 1983; Zalm 1988). Labour market conduct of women for example has changed in the course of time because ethical, religious and mental attitudes have changed. Therefore it is difficult to make a prognosis of future labour market behaviour.

The oldest macroeconomic model is the business cycle model, published by Tinbergen in 1936, in which expenses are an important variable. In a business cycle model short-term changes in industry are the main issue (De Wolff 1983; Van der Geest 1984).

Business cycle models have following characteristics:

1. They are demand models: production functions are not found in these models. Value added, net national income, are constructed by aggregation of expenses or incomes.

2. Relative mutations are important, e.g. percentagewise changes of national income or short-term employment. Often statistical time series are used (Wartna 1974). One can consider these models as the first generation of macroeconomic models. In the seventies models were developed in which attention was paid not only to demand, but also to supply structures. These models are meant for a longer term. They are at the same time models of economic growth and of the business cycle.

Economic structure models are mainly supply models which represent a trend. In the long term the question arises whether production can be extended: will there be enough labour and capital available? In economic structure models production functions are important. In these models the absolute or relative level of units of account is important instead of relative mutations. By using logarithms curvilinear trends can be pictured. In economic structure models time-lags are, if possible, avoided with endogenic variables. The sample period for the statistical measurement of coefficients should be as long as possible, because an economic structure model is meant for long-term prognoses (Wartna 1974 p.102 e.v.). 
In the seventies and eighties sectorial models, which pay attention to branches of industry and regions were developed in the Netherlands. In the nineties the first micro-macro models were presented. The macro model was underpinned by micro models. These models are general equilibrium models in which producers and consumers play a role. Consumers maximize utility, producers maximize profits. An equilibrium is reached by compilations of prices and quantities in such a way that supply and demand in every market are equal and nobody wishes to change his behaviour (Compaijen and Den Butter 1982 p.22; Gelauff and Graafland 1994 p.5 ff).

In the seventies the enthousiasm for macroeconomic models dwindled, because these models could not explain stagflation, pollution of the environment or massive inactivity of people having social security benefits. Moreover there was criticism because the theoretical underpinning was not empirically founded by microeconomical data of human behaviour (Van der Geest 1983; Gelauff and Graafland 1994 p.4; Graafland and Zalm 1994 p.610). The technique of estimations was also criticized (Den Butter 1983).

Another shortcoming arose when relations, which existed in reality, were lacking or wrongly quantified (Zalm 1988). Statistical time series were thought to be usable for short-term predictions, but not for long-term prognoses (De Jong e.a. 1983; Kuipers 1983). In 1983 Dutch economists concluded a discussion on the value of macroeconomic models by saying that these models could contribute to policy making, especially to quantitative economic policy, on the understanding that economic science as well as macroeconomic models have their limitations (Kuipers 1983). Hennipman already warned much earlier that it is an illusion to think that a foolproof and entirely exact economic policy could be attained thanks to economic science. Every decision brings along an analytically and empirically smaller or greater uncertainty (Hennipman 1962).

Macroeconomic models do not consider unpaid work and ignore the fact that, as a result of privatization and public sector reforms, many activities such as health care have been shifted from the public sector to the private sector. This is equivalent to assuming an unlimited supply of unpaid labour (Çagatay, Elson and Grown 1995).

\subsection{Models with special attention to gender}

Ertürk and Çagatay (1995) presented a theoretical general model of growth cycles with special attention to gender. It is a simple Kaldorian model in which the rate of feminization of the labour market and the intensity of fernale household labour have been introduced as separate arguments. They assume that one part of investment demand is induced in short run changes in the capacity utilization rate, and the other part is cost determined in the longer run. A rise in the rate of feminization of the labour market stimulates investment because labour costs are decreasing. A rise in the intensity of female household labour (workload 
determined by length and intensity of effort) makes savings rise. It is assumed that during an economic contraction the need for dissaving diminishes as the share of nonmarket goods and services increases, whereas during an economic expansion savings are negatively affected because less nonmarket goods and services are produced. If during a contraction of the economy the intensity of household work rises faster than the feminization of the labour market the likelyhood of economic recovery is less than in the reverse case. The model has not empirically been tested, because data on the cyclical development of the feminization of the labour market and on the intensity of household labour were not available. In my eyes this is an interesting conjecture which should be elaborated upon further.

In 1987 Graafland presented a model describing and analysing the links between the formal economy and the informal economy (household sector and underground sector) in particular the labour market and the consumer market. He used a small comparative static equilibrium model. The underground economy was defined as the economy of paid illegal transaction (no payment of tax or social premiums) which compete with transactions in the formal economy. The household sector was defined as unpaid transactions (household and voluntary work) which save expenses in the formal economy. As an exact estimation of the underground economy was not available, Graafland made two variations, estimating underground economy at $5 \%$ and at $10 \%$ of GNP. The household sector was estimated at $5 \%$ of GNP. Graafland made this restriction for the household sector because he thought that only $5 \%$ of the activities inside the household could compete with activities in the formal economy (Graafland 1987 p.3 and p.18). An individual CES-utility function, in which leisure and consumption figure, was optimalized. Working people divide their time between the labour market, the black market and the household sector, nonworking people divide their time between the black market and the household sector. A distinction is made between an informal labour market, where the black wage is the result of supply and demand, and a household sector, where the "wage" depends on the savings of expenses in the formal sector caused by household production. It is not clear how Graafland estimated this "wage". This model shows a simulation of the effects of a lower income tax rate, a lower rate of VAT, lower government expenses, a wage moderation of $2.5 \%$, a shortening of working hours with $5 \%$. The quantitative effects of the informal economy (mainly the underground sector) on the formal economy and vice versa, which Graafland. found, are very small. Graafland himself concludes that a more detailed model of the household sector would be important (Graafland 1.987 p. 46).

In my eyes a percentage of $5 \%$ of GNP for household production is much too low. Substitution of unpaid work by paid work can be realized by using capital goods or by having paid work done by third persons. However, working women save time by eating out and hiring home help (Tijdens et al. 1994). Working mothers use more child care than nonworking mothers. The more hours mothers participate in the labour market, the more hours of child care they use (Groot and Maassen van den Brink 1992; CBS 1993; Maassen van den Brink et al. 1995). In. 
principle all household production can be done by third persons: one can hire a housekeeper or go and live in a hotel or boarding house. Working women without children spend 15-17 hours a week less on household production than housewives, their male partners spend 2 hours more than the partners of nonworking women. Working women with children spend 20-22 hours less than housewives, their male partners spend 0 to 4 hours more than the partners of nonworking women (Ministry of Social Affairs 1995 Suppl.5, table 2.3).

\subsection{Criticism on MIMIC: an extended household sector model of the Netherlands Central Planning Bureau}

MIMIC (MIcro Macro model to analyse the Institutional Context), is a micro-macro model of the Netherlands Central Planning Bureau. To be able to explain the criticism on MIMIC, the model is rather extensively described in this section. MIMIC has specially been constructed to show behavioural consequences of changes in taxation and social security, to predict long-term labour market behaviour in a changing institutional context. MIMIC is an applied general equilibrium model with New Keynesian elements. It distinguishes three submodels, describing the behaviour of the firm and of households and the confrontation between labour supply and demand. The main elements of the model of the firm are a monopolistic competitive output market environment, a monopsonistic (labour) input market, a CES-production function and a cost function that includes factor adjustment costs. Domestic firms have been divided into six sectors.

The household model describes private consumption and labour supply. In the utility function utility of consumption and leisure is maximized:

$U=(c / c+\beta d)$

In $\mathrm{c} / \tilde{\mathrm{c}}$ consumption is compared to the average consumption of a reference group $\tilde{c}$. Leisure is given in $d$ and the coefficient of leisure $\beta$ can be interpreted as the relative preference for leisure of a household.

The budget constraint is:

$\left.P_{c C}=\left(1-s_{y}\right)\left(\left(1-t_{b}\right)\left(w_{b} l_{b}+z_{b}\right)+\left(1-t_{p}\right) w_{p} l_{p}+z_{n}\right)\right)$

in which $P_{c}$ is the price of consumer goods; $s_{y}$ is the savings rate; $t$ is the average rate of taxation and social security premiums; $w$ is the wage rate per hour; $\mathrm{l}$ is the number of hours worked; $\mathrm{z}$ is non-wage income. Subscipts $\mathrm{b}$ and $\mathrm{p}$ denote breadwinner and partner respectively. A part of non-wage income is subject to taxation $z_{b}$ and a part is exempt from taxation $z_{n}$. 
The time constraint of the household is:

$h=l_{b}+l_{p}+d$

in which $\mathrm{h}$ is the total time available to the household.

Labour supply in MIMiC is based on the male-chauvinist model, meaning that only labour supply of partners is endogenized. Generally labour supply of breadwinners is empirically found to be rather insensitive to income of the partner participating in the labour market, so working time (lb) of the breadwinner is supposed to be exogenous. Net income of breadwinners is derived from gross income and the statutory rates of taxation and social security premiums through the use of class-frequency income distributions of gross breadwinner incomes.

Working time of the partner $\left(l_{p}\right)$ depends on the wage rate of the partner, the marginal tax rate, net income of the breadwinner and the partner's preference for leisure. In the labour supply block the participation rate, the average number of working hours supplied, the weighted average tax rate and the weighted marginal tax rate of partners are determined. Heterogeneity has been introduced by assuming that households differ with respect to the relative preference for leisure as reflected by the parameter $\beta$ in (1). Each household chooses the number of hours the partner wishes to work on the labour market by maximizing a CESutility function with consumption and leisure and a kinked budget curve which follows from the income bracket tax system.

The third submodel in MIMIC concerns contractual wage formation, the search intensity of unemployed and the matching process between vacancies and unemployed persons. Wages are set above market-clearing levels, generating equilibrium unemployment. Government behaviour is largely exogenous. Tax rates and the volume of most public outlays are given, prices of govemment expenditure and the public wage rate are linked to private sector variables. The public deficit is endogenously determined and feeds back into government debt and interest charges on government debt. Four types of government institutions can be distinguished: three indirect tax rates; the official minimum wage rate; the statutory income tax and social security premiums; social benefits for unemployment and disability.

Plantenga and Sloep (1995) criticise MIMIC because they think that in the household block more attention should have been given to unpaid work. They point out that the way formal work has been organized presupposes a certain way of organizing informal work. If labour market participation of women increases, less time is available for child care and voluntary work. The interaction between the formal and informal circuit can only be shown if participation in both circuits is modelled at the same time. Plantenga and Sloep illustrated their statements in figure 7.1 . 


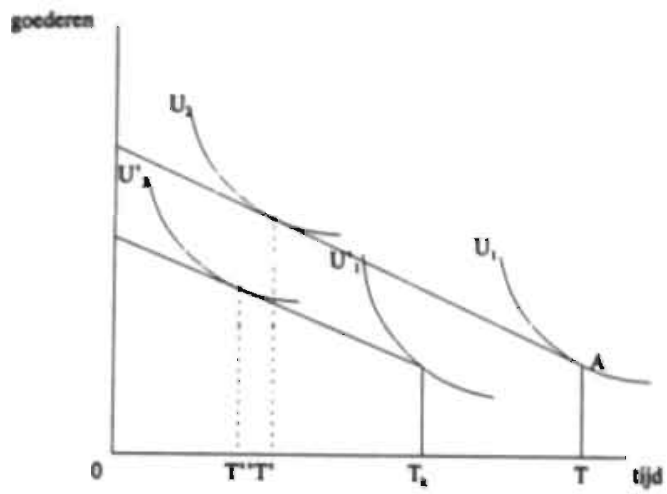

Figure 7.1. (Plantenga and Sloep 1995 p. 46)

Utility curve $U_{1}$ shows the preferences of a partner with a reservation wage as high as the wage in point $\mathrm{A}$. A decrease of available hours for the labour market as a consequence of child care makes the budget function go to the left. This partner will not participate in the labour market. If $U_{2}$ is the new preference curve, the effect of a decrease of available time because of child care has the same consequences as a decrease of other income. Time on the labour market decreases with $\mathrm{T}^{\prime \prime}-\mathrm{T}^{\prime}$.

Plantenga and Sloep argue that government policy influences partner's time available for the labour market by way of child care facilities, parental leave, a legal right to work part-time. Government policy concerning health care, care for the elderly and education also influences partner's time: a shortening of intramural care after hospitalization, waiting lists for homes for elderly people or reduced government spending on education costs informal time and has repercussions for partner's time available for the labour market or other activities. Plantenga and Sloep propose to integrate unpaid work in this model by implementing the following adaptations:

1. To change the choice between time on the labour market and leisure in a choice between time on the labour market, leisure and time for unpaid production.

2. Time available for paid work is dependent on government policy concerning expenses for child care, health care, care for elderly and handicapped people, education etc. as shown in figure 7.2. 
Figure 7.2. shows the relations in the householdmodel of MIMIC. An extra relationship between households and government is added: government policy is an input variable for the household model together with tax and social premium rates. The participation rate of unpaid work is an input variable for the government sector together with tax and social premiums revenues and social assistance benefits. Figure 7.2. shows the household block of MIMIC in which the additions of Plantenga and Sloep are shadowed.

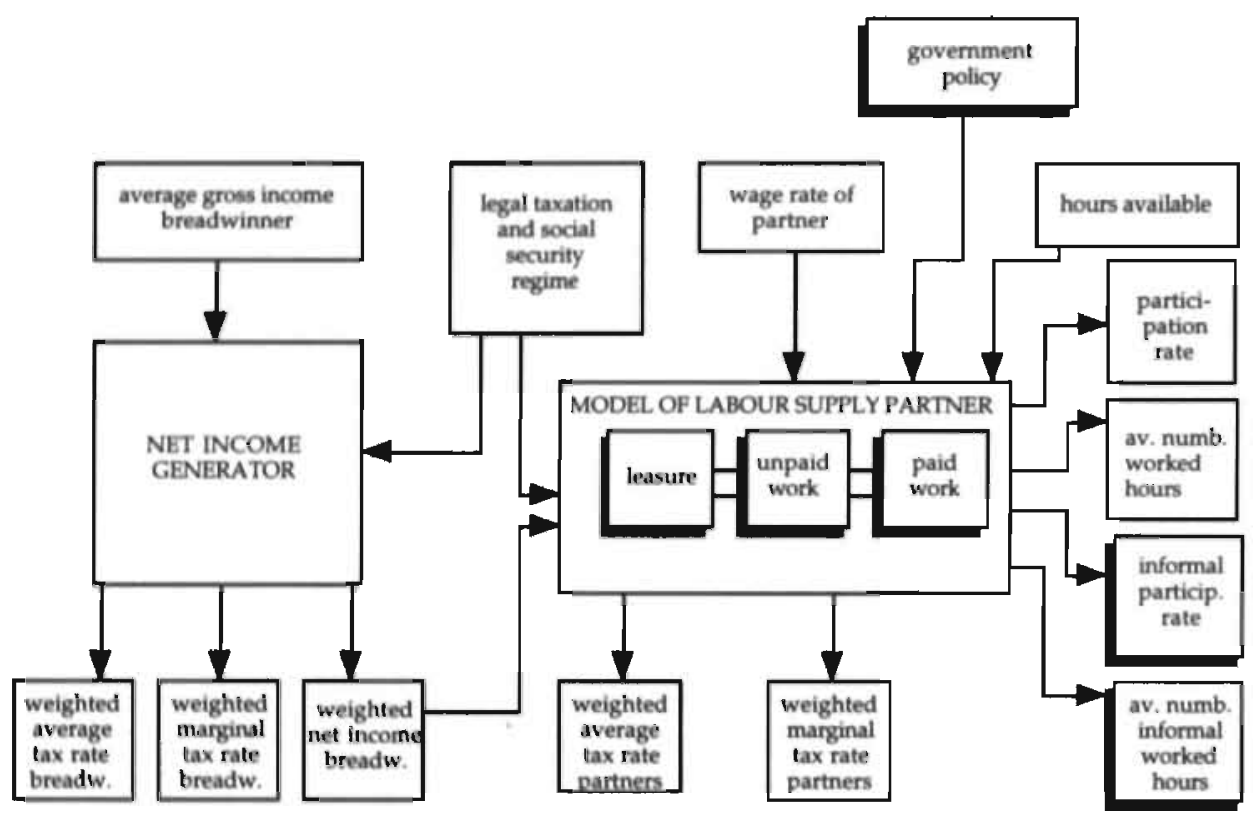

Figure 7.2. (Plantenga and Sloep 1995 p. 51)

I agree with the criticism of Plantenga and Sloep, but I think their criticism does not go far enough. In section 7.6. suggestions will be made not only regarding the way the household block is modelled but also regarding the absence of unpaid work in the whole model. Before expanding the criticism on macroeconomic models more research is presented on the relation between paid and unpaid work, research which in my eyes supports the criticism of Plantenga and Sloep. 


\subsection{The relation between paid and unpaid work}

Knulst of the Social and Cultural Planning Office made several researches about the relation between paid and unpaid work and other activities by means of a regression analysis based on time use surveys. He found that for men, unlike women, paid working time is a good predictor for their time use on other activities. For women total time spent on paid plus unpaid work is a good predictor for their time use on other activities (Knulst and Schoonderwoerd 1983 p. 119).

Driehuis (Bruyn-Hundt et al. 1983) also found a significant difference between men and women concerning the relation between paid and unpaid work and other activities (Bruyn-Hundt et al. 1983 p.95)

Another approach was used by Van der Lippe and Niphuis-Nell of the SCP (Van der Lippe and Niphuis-Nell 1994). They made a regression analysis on the influence of educational level, age, hours of paid work, age of youngest child, partner, house, and household help, and time spent on household production. They found that for men paid hours of work were the most important variable: a man with a paid job of 40 hours or more a week, spends 14 hours a week less on household tasks than a man without a paid job. For women the age of the youngest child and hours of paid work were equally important: a youngest child of $0-5$ years old is good for 18 hours more unpaid work. Educational level and age influence household production for both men and women, but this correlation is less important. For men and women the lowest level of education is good for nearly two hours more unpaid work a week. For all men and all women together one hour of paid work extra in 1990 meant a reduction in unpaid work of 35 minutes for women and of 23 minutes for men. Their research also shows that unpaid work is most equally divided if paid work is equally divided, that is the case if both partners have a paid job of 30 hours a week or more (Van der Lippe and Niphuis-Nell 1994 p.57).

In MIMIC Gelauff and Graafland suggest a close relationship between labour market participation of women, the level of their professional skills, employment of the husband and the presence of any children. Indirectly they recognize that there is a relation by supposing that a partner with child(ren) has 20 hours a week less available for labour market participation.

The relation between paid and unpaid work is further investigated in this section by using the Intomart time use surveys. These surveys offer the possibility to link paid and unpaid work, because respondents mark in their diaries the hours of paid as well as of unpaid work. The size of the samples restricted the possibility to subdivide the time data over sub-categories. Therefore I put together the samples of 1985 and 1990 (the same questions were asked in both years). For the calibration of the labour supply MIMIC distinguishes 8 types of households, which I followed as closely as possible and I added two other variables: the age of the youngest child and the way in which partners earn their living. 
In table 7.1. data of household types with 10 or less respondents are left out. In this way the following combinations cannot be found in table 7.1.:

- single males with a low educational level and working 1-19 hours a week

- female one-earners and their partners

- female-headed two-earner households

Table 7.1.

Time use in hours a week to household production + voluntary work (1), paid work (2) and total work $(1+2)$ per household type, sex and educational level (years 1985 and 1990)

MEN:

\begin{tabular}{|c|c|c|c|c|c|c|c|c|}
\hline Hours of work & 1 & & 2 & & $1+2$ & & $N$ & \\
\hline Educational level & low & high & low & high & low & high & low & high \\
\hline $\begin{array}{l}\text { Single people: } \\
\text { - unemployed }\end{array}$ & & & & & & & & \\
\hline - 1-19 hours employed & - & 14 & - & 14 & - & 28 & - & 20 \\
\hline - 20 hours > employed & 15 & 14 & 39 & 40 & 54 & 55 & 57 & 108 \\
\hline
\end{tabular}

Partner without children:

- unemployed

- one-earner
29

17

=two-earner

16

\section{6}

14

Partner with children:

Youngest child $0-5$ years

- unemployed

- one-earner

- two-earner

Youngest child 6-12 years

- unemployed

- one-earner

- two-earner

Youngest child $13>$

- unemployed

- one-earner

- two-earner

Breadwinner unemployed, working wife:

- without children

- with children

One-parent families

Children 18-25

Single people $65+$

Partners 65+

\begin{tabular}{|c|c|c|c|c|c|c|c|}
\hline 29 & - & 8 & - & 37 & - & 18 & - \\
\hline 20 & 21 & 42 & 41 & 62 & 62 & 161 & 164 \\
\hline 19 & 21 & 40 & 44 & 59 & 65 & 28 & 71 \\
\hline- & - & - & - & - & - & - & - \\
\hline 16 & 17 & 45 & 43 & 61 & 60 & 74 & 78 \\
\hline 15 & 16 & 45 & 43 & 60 & 59 & 40 & 45 \\
\hline 36 & 31 & 2 & 1 & 38 & 32 & 32 & 16 \\
\hline 16 & 13 & 39 & 45 & 55 & 58 & 67 & 60 \\
\hline 14 & 15 & 38 & 38 & 52 & 53 & 42 & 49 \\
\hline
\end{tabular}

\begin{tabular}{rrrrrrrr}
26 & 23 & 2 & 2 & 28 & 25 & 15 & 11 \\
- & - & - & - & - & - & - & - \\
18 & 28 & 36 & 21 & 54 & 49 & 23 & 20 \\
28 & 36 & 11 & 8 & 39 & 43 & 68 & 54 \\
32 & 24 & 1 & 2 & 33 & 26 & 36 & 29 \\
27 & 27 & 2 & 2 & 29 & 29 & 171 & 95 \\
\hline
\end{tabular}


- partners both working part-time

- unemployed low-skilled couples with youngest child 6-12 years

- unemployed high-skilled couples with children aged 0-5 years

Partners with a nonworking breadwinner and a working wife are scarce.

Time use in hours a week to household production + voluntary work (1), paid work (2) and total work $(1+2)$ per household type, sex and educational level (years 1985 and 1990)

\section{WOMEN:}

\section{Hours of work \\ Educational level}

Single people:

- unemployed

- 1-19 hours employed

-20 hours $>$ employed

Partners without children:

- unemployed

- one-earners

- two-eamers

1

1

low high

2

low

39

38

24

$\begin{array}{ll}42 & 38 \\ 44 & 39 \\ 28 & 23\end{array}$

58

49

- two-earners

Youngest child 6-12

- unemployed

- one-earners

- two-earners

Youngest child 13 >

- unemployed

- one-eamers

- two-eamers

Breadwinner unemployed,

working wife:

- without children.

- with children

One-parent family

Children 18-25

Single people $65+$

Partners $65+$

27
19
19

39

1
28

Partners with children:

Youngest child $0-5$ years

- unemployed

- one-earners

\begin{tabular}{|c|c|c|c|c|c|c|c|}
\hline 58 & - & 0 & - & 58 & - & 18 & - \\
\hline 58 & 58 & 1 & 1 & 59 & 59 & 22,4 & 269 \\
\hline 49 & 48 & 12 & 14 & 61 & 62 & 68 & 126 \\
\hline- & - & - & - & - & - & - & - \\
\hline 52 & 52 & 1 & 1 & 53 & 53 & 131 & 121 \\
\hline 44 & 41 & 14 & 17 & 58 & 58 & 67 & 101 \\
\hline 46 & 47 & 1 & 1 & 47 & 48 & 45 & 13 \\
\hline 49 & 46 & 1 & 2 & 50 & 48 & 113 & 81 \\
\hline 37 & 36 & 18 & 19 & 55 & 55 & 74 & 59 \\
\hline
\end{tabular}

1
13

33

2
10
34

40

51

$\begin{array}{rrr}29 & 102 & 72 \\ 29 & 10 & 22 \\ 53 & 413 & 125\end{array}$

57

42

45

38

38
41

105

55

56

53

$116 \quad 175$

82

$\begin{array}{rrrrrrrr}58 & - & 0 & - & 58 & - & 18 & - \\ 58 & 58 & 1 & 1 & 59 & 59 & 224 & 269 \\ 49 & 48 & 12 & 14 & 61 & 62 & 68 & 126 \\ & & & & & & & \\ - & - & - & - & - & - & - & - \\ 52 & 52 & 1 & 1 & 53 & 53 & 131 & 121 \\ 44 & 41 & 14 & 17 & 58 & 58 & 67 & 101 \\ & & & & & & & \\ 46 & 47 & 1 & 1 & 47 & 48 & 45 & 13 \\ 49 & 46 & 1 & 2 & 50 & 48 & 113 & 81 \\ 37 & 36 & 18 & 19 & 55 & 55 & 74 & 59\end{array}$


Table 7.1. shows that:

1. In all household types the presence of a young child, as well as the educational level bear a negative correlation with the percentage of two-earners. The percentage of two-earners is highest in households without children and a high educational level $(41 \%$ of male partners without children; $56 \%$ of females). More than $50 \%$ of partners without children are two-earners, whereas only about $1 / 3$ of partners with children are two-earners.

2. Two-earners with youngest child between $0-5$ years of age and a high educational level have the highest total workload: for men this means on average 65 hours a week, for women on average 62 hours a week. Fathers with a high educational levell do 2 hours of unpaid work and 4 hours of paid work more than fathers with a low educational level. The percentage of oneearners is highest in households with a young child and a low educational level ( $78 \%$ of male one-earners and 72 of female partners).

3. The female two-earners have a much lower paid workload than the male two earners. Females work 12 to 19 hours, males 38 to 45 hours a week. These data confirm the so-called one-and-half-earners strategy of de Jong and Van Olde (1993).

4. Paid and unpaid work are in competition: there is no big difference between the total workload of men and women with children under 12. This applies especially to two-earners: their total workload is 58-65 hours a week. The workload of partners of one-earners is slightly lower than that of their husbands: 53-59 hours against 60-62 hours a week.

5. If men are unemployed they have a relatively high unpaid workload. Partners of unemployed men and of one-earners with a young child have the highest unpaid workload.

6. It is realistic to assume, as MIMIC does (Gelauff and Graafland 1994 p.103), that for partners without children the total number of hours available for work on the labour market is higher than for partners with children. MIMIC arbitrarily puts this on 20 hours a week. Table 7.1. suggests that the age of the youngest child should be taken into account instead of the presence of "children" in general. Table 7.1. shows that female two-earner partners without children have 91 to 25 hours less unpaid work than mothers. Instead of an arbitrary amount of 20 hours, a difference could be introduced between women without children and:

women with youngest child 13 years > : 9-13 h. less unpaid work with youngest child $6-12$ years with youngest child $0-5$ years

: 16-18 h. less unpaid work

: $21-25 \mathrm{~h}$. less unpaid work

Table 7.1. does not give information on the division of voluntary work between men and women in the different household types. Therefore in table 7.2. unpaid work has been divided into household production and voluntary work according to sex and per household type. 
Table 7.2 .

Time use in hours a week on household production (1) and voluntary work (2) in the period 1985/1990

$\frac{N}{m} \frac{(1)}{m} \frac{(2)}{m} \frac{N}{f} \frac{(1)}{f} \frac{(2)}{f} \frac{(1)}{m+f} \frac{(2)}{m+f}$

Single $<65$ unemployed

$-1-19$ hoursemployed

-20 hours >employed

Partners without children

- unemployed

- one-earners

- two-earners

Partners with children

Youngest child $0-5$ years

- unemployed

- one-earners

- two-eamers

Youngest child 6-12 years

- unemployed

- one-earners

- two-earners

Youngest child 13 years $>$

- unemployed

- one-earners

- two-eamers

One-parent families

Children 18-25

Single peopls $65+$

Partners 65+

Total $N$

$\begin{array}{rrrrrr}114 & 18,9 & 2,4 & 188 & 30 & 2,9 \\ 23 & 11,2 & 3,6 & 37 & 21,3 & 2,7 \\ 168 & 12,9 & 1,2 & 172 & 18,6 & 1,8\end{array}$

$\begin{array}{rrrrrrrr}149 & 23,8 & 3,7 & 169 & 38,2 & 2,2 & 63 & 5,8 \\ 133 & 13 & 2,4 & 177 & 38,6 & 2,7 & 55,2 & 5,2 \\ 242 & 14 & 1,0 & 301 & 23,3 & 1,1 & 38,4 & 2,2\end{array}$

$\begin{array}{rrrrrrrr}28 & 28 & 5,3 & 22 & 55,7 & 0,8 & 80,4 & 6,6 \\ 330 & 18,6 & 2,1 & 497 & 55,8 & 1,8 & 82 & 3,8 \\ 99 & 18,4 & 1,8 & 199 & 47 & 1,5 & 74 & 3,2\end{array}$

$\begin{array}{rrrrrrrr}10 & 19,3 & 4,4 & 15 & 42,6 & 2,8 & 66,5 & 7 \\ 154 & 14,4 & 2 & 257 & 48,6 & 3,3 & 71,6 & 5,6 \\ 85 & 13,9 & 1,6 & 170 & 40,2 & 2,1 & 62,8 & 3,8\end{array}$

$\begin{array}{rrrrrrrr}48 & 27,7 & 7 & 64 & 44,1 & 2 & 74,1 & 4,1 \\ 128 & 12,2 & 2,5 & 195 & 44,4 & 3,2 & 63,2 & 5,8 \\ 89 & 13 & 2,1 & 132 & 34,1 & 2,0 & 51,2 & 4,2\end{array}$

$\begin{array}{llllll}48 & 18,8 & 2,9 & 169 & 38,5 & 2,3\end{array}$

$\begin{array}{llllll}169 & 7,7 & 1,6 & 141 & 14 & 1,4\end{array}$

$\begin{array}{llllll}65 & 26,4 & 2,3 & 225 & 32 & 2\end{array}$

268

$23,2 \quad 3,5 \quad 188$

35,6

1,6

$56,6 \quad 5,4$

Source: 1985 and 1990 micro data of Steinmetz Archief.

Table 7.2. shows that the size of voluntary work done by nonworking men is remarkably high, especially if they have older children ( 5 to 7 hours a week). The male two-earner does least ( 1 hour), followed by the working single man. Male one-earners are in between. The differences in time spent on voluntary work by women are much smaller: women do 1 to 3 hours voluntary work a week. Partners of one-earners with older children do most: 3.2 to 3.3 hours a week. 
Research presented in tables 7.1. and 7.2. shows that there is a relationship between paid and unpaid work. Therefore I have made a correlation analysis between paid and unpaid work by sex and per household type. It is evident that this analysis could only be made for those people combining paid and unpaid work.

Table 7.3. shows that the correlation between paid and unpaid work is highest with two-earners with young children followed by male one-earners. Among females single parents score highest whereas correlation is lowest for two-earner fernales without children. Among males correlation is exceptionally high with two-earners with youngest child $0-5$ years and exceptionally low with single men. The intercept is higher for women which means that if women do not do any paid work they do more unpaid work than men in ditto circumstances. The slope is strongest with female one-parent families which means that substitutiton of paid to unpaid work and vice versa is greatest: 1 hour paid work extra means 0.627 hours unpaid work less. With male two-earners youngest child $0-5$ this substitution is 0.544 hours of unpaid work for every paid hour. For all women aged 17-64 (including women not participating in the labour market) the correlation is:

unpaid hours $=46.67-(0.627 \times$ paid hours $)$ with $R^{2}=0.326$.

This means that if women do not do any paid work, they do nearly 47 hours unpaid work and every paid hour leads to $0.627 \times 60$ minuten $=38$ minutes less unpaid work. Nearly $33 \%$ of variance in unpaid hours of work is explained by paid work.

With men aged 17-64 the correlation is following: unpaid work $=25.60-(0.244$ paid work $)$, with $\mathrm{R}^{2}=0.183$.

This means that if men would not do any paid work, they would do 25.6 hours a week unpaid work. For every hour of paid work they substitute $0.244 \times 60$ minutes $=15$ minutes unpaid work. Only $18 \%$ of variance in unpaid work is explained by paid work. 
Table 7.3.

Correlation between paid and unpaid work by sex and per household type in hours per week $1985 / 1990$

$$
\text { r }
$$

$R^{2}$

$\begin{array}{lllll}-0.474 & 0.224 & 29.98 & -0.286 & 172 \\ -0.131 & 0.017 & 41.76 & -0.341 & 177 \\ -0.578 & 0.334 & 56.56 & -0.610 & 199 \\ -0.581 & 0.337 & 50.68 & -0.534 & 170 \\ -0.441 & 0.194 & 44.15 & -0.426 & 131 \\ -0.558 & 0.311 & 52.16 & -0.581 & 502 \\ -0.597 & 0.356 & 46.46 & -0.596 & 169 \\ -0.230 & 0.053 & 17.90 & -0.123 & 141\end{array}$

All women $17-64$

(inclusive nonworking women)

$-0.571$

$-0.627 \quad 3159$

Women

single

- two-eamers youngest child 6-12

- two-earners youngest child $>13$

All two-earners with children

One parent

Children 17-25

\section{$-0.571$}

$\mathbf{r}$

$$
\mathrm{R}^{2}
$$

intercep

slope

$\mathrm{N}$

\section{Men}

- single

- two-earners without cildren.

- two-earners youngest child 0-5

- two-earners youngest child 6-12

- two-earners youngest child $>13$

All two-earners with children

Single parent

Children 17-25

- one-earner.without children

- one-eamer youngest child 0-5

- one-arner.youngest child 6-12

- one-eamer youngest child $>13$

All one-earners with children

$\begin{array}{rrrrr}-0.260 & 0.068 & 19.34 & -0.133 & 168 \\ -0.462 & 0.213 & 25.43 & -0.258 & 242 \\ -0.652 & 0.425 & 43.54 & -0.544 & 99 \\ -0.394 & 0.155 & 28.77 & -0.303 & 85 \\ -0.325 & 0.105 & 22.37 & -0.179 & 83 \\ -0.425 & 0.181 & 30.06 & -0.309 & 273 \\ -0.430 & 0.185 & 29.53 & -0.300 & 48 \\ -0.239 & 0.057 & 11.29 & -0.083 & 169 \\ -0.595 & 0.354 & 29.63 & -0.387 & 133 \\ -0.603 & 0.364 & 40.11 & -0.470 & 330 \\ -0.581 & 0.338 & 34.66 & -0.417 & 154 \\ -0.479 & 0.229 & 27.21 & -0.309 & 126 \\ -0.567 & 0.321 & 36.22 & -0.426 & 613 \\ & & & & \\ -0.427 & 0.183 & 25.60 & -0.2 .44 & 2220\end{array}$

Tables 7.1. and 7.2. support the criticism of Plantenga and Sloep. Labour market supply is closely connected with the organization of unpaid work. Economists explain women's labour market participation by looking at financial incentives such as the development of female wages, taxation and social security, husband's income and changes in demographic and socio-economic variables e.g. female education, number and age of the children (Killingsworth and Heckman 1986).

Social and cultural habits and norms also play a role. Pott-Buter (1993) thinks that the participation rate of Dutch women was low until the eighties because Dutch women have a strong preference to care for their children themselves. 
Fewer children, better household technology and rising female wages caused a change in this attitude. Vendrik (1993) explains women's growing labour market participation by a shift in individual and collective habits and social norms from housewife to emancipated woman with a paid job (Vendrik 1993). How habits and norms can be empirically underpinned and implemented in macroeconomic models is an unanswered question.

\subsection{The implementation of unpaid work in macro models}

The influence of unpaid work on the economy is not restricted to the household sector or labour supply. Size and composition of production, consumption, savings and investment change, welfare and growth rates differ if unpaid work is taken into account, fluctuations of the business cycles are better measured, definitions of employment and unemployment change. Therefore unpaid work should be implemented in the whole macroeconomic model. The arguments in favour of implementation of unpaid work in the National Accounts mentioned in chapter 5 are also valid for the implementation of unpaid work in macroeconomic models. Figure 7.3. illustrates how our view on the economy is extended if unpaid work is implemented.

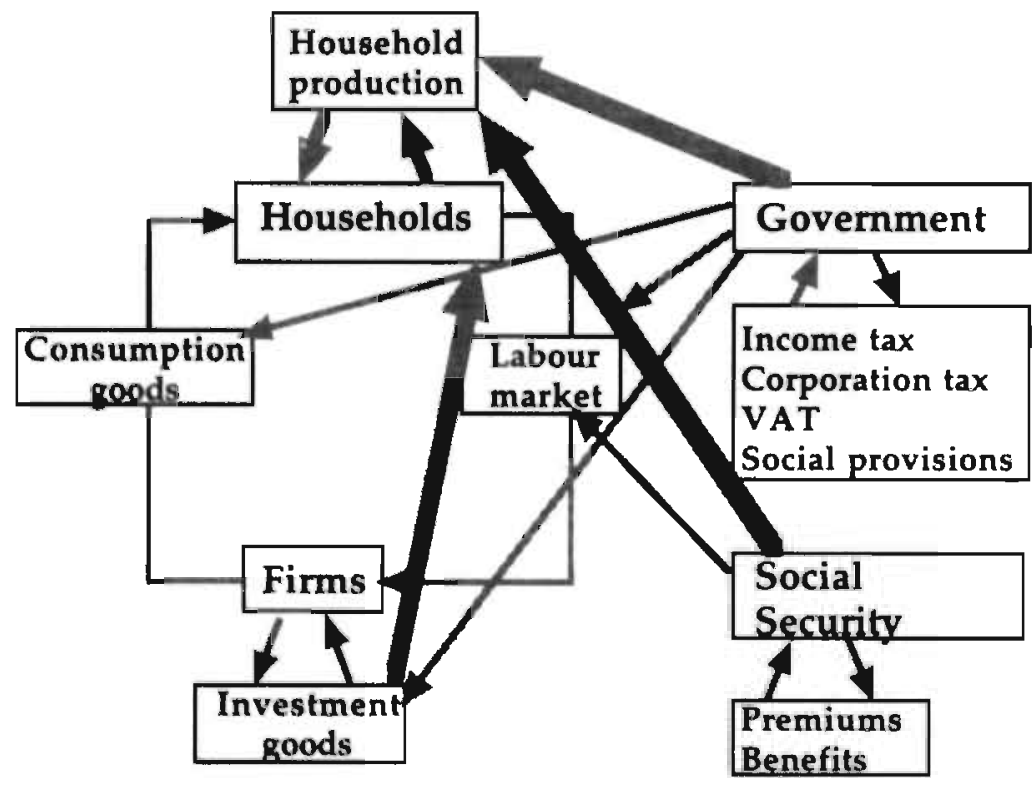

Figure 7.3. 
In figure 7.3. the relations between Households, Firms, Government and the Social Security sector as they exist in most macroeconomic models are given by small arrows. No distinction is made between flows of goods and flows of money. The labour market is situated between Households (supply) and Firms (demand). The market of consumption goods is situated between Firms (supply) and Households (demand). For the sake of simplicity Financial Institutions and the Rest of the World are left out, Government as employer and Government as supplier of collective consumption goods is thought to be part of Firms. Savings are left out because financial institutions are left out. Firms produce capital goods and (partly) finance them themselves. Government influences the labour market by the construction and level of Income tax and Corporation Tax, by social provisions e.g. Exployment Exchange, Professional Training, Social Assistance Benefits, Child care. Size and composition of the market of consumer goods is influenced by tax policies and social security premiums and benefits. Supply and demand of investment goods between firms is influenced by Corporation tax, Income tax and VAT. GNP consists of C(onsumption goods) and Gross I(nvestments).

The broad, large arrows are added to show the relationships in a macroeconomic model in which unpaidl work is taken into account: household production increases GNP and Consumption, Firms deliver not only Consumption Goods but also Investment Goods to Households. Tax policies, social provisions and social security policies influence size and composition of household production as well as other Government programmes for Health Care, Home Help, Homes for the elderly, etc.

As I am neither an econometrist nor trained in constructing models I hope that better trained people than I will be able to use the results of the chapters 5-7 to build a macro model in which unpaid work will be integrated. My suggestions are following:

1. Household production and voluntary work should be regarded as part of GNP for purposes of comparing international and intertemporal growth rates and comparing welfare. I calculated the value of unpaid work at minimum wages as 51 to $68 \%$ of GNP in the period $1975-1990$.

2. If a model is used in which a utility function is maximized, household production and voluntary work should be regarded as a special part of Consumption and not as Leisure. For women, especially if there are young children, time not spent on the labour market does not show her preference for leisure, but the necessity to produce care for her family, to increase income in kind for the household. The same argument applies for all types of households: although there are individual differences in the degree of dirt people tolerate, most people care for a clean house and clean clothes. People have to do a minimum of unpaid work. The "preference" for unpaid work could be introduced in the utility function. In MIMIC this would be: 
where $c_{y}$ is consumption bought on the market and Ch. is consumption produced at home.

3. If a time constraint is built into the model the time spent on household production and voluntary work should be given a place. In that way it is easier to assess how many people and how many hours are available for participation in the labour market or for voluntary work if the Government wants to economize on expenses for care by substituting paid care for unpaid care.

$h=l_{b}+h_{b}+v_{b}+l_{p}+h_{p}+v_{p}+d$

$l_{b}$ denotes the number of hours the breadwinner spends on the labour market, $h_{b}$ denotes the number of hours he spends on household production, $\mathrm{vb}$ denotes the time he spends on voluntary work (for voluntary work see table 7.2.) The same indications with subscript $p$ give this information for the partner.

Figure 2 in chapter 2 illustrated the incorporation of unpaid production in the utility function and in the budget constraint in a micro model of household production based on Gronau.

4. If the model has a labour supply equation it should be extended with a supply function of unpaid work. A regression analysis of household production for the whole population of time use surveys 1985 and 1990 is shown in table 7.4.: $\mathrm{ul}=$ supply of hours of unpaid work;

ch $=$ children present;

$\mathrm{I}_{\mathrm{b}}=$ hours of paid labour of the (main) breadwinner;

$I_{p}=$ hours of paid work of the partner;

ed = level of education:

$\mathrm{s}=\operatorname{sex}$

Table 7.4.

Regression of unpaid household production for the whole population $\left(\mathrm{N}=6678, \mathrm{R}^{2} 0.337, \operatorname{sig} \mathrm{F} 0.0000\right)$

\begin{tabular}{lrl} 
& \multicolumn{1}{c}{ B } & Sig T \\
\hline ch & 2.82244 & 0.0001 \\
lb & -0.23609 & 0.0000 \\
lp & -0.10934 & 0.0001 \\
ed & 0.01434 & 0.9270 \\
s & 21.91362 & 0.0000 \\
constant & -5.15069 & 0.0201 \\
\hline
\end{tabular}


The level of education does not have any influence, being a female is most important for the supply of hours of unpaid work.

Correlation becomes stronger $\left(\mathrm{R}^{2}\right.$ is 0.62$)$ if the analysis is restricted to partners with and without children as is shown in table 7.5.

\section{Table 7.5.}

Regression of unpaid household production for partners with and without children $\left(\mathrm{N}=4240, \mathrm{R}^{2} 0.616417\right.$, Sig F 0.0000)

\begin{tabular}{lrl}
\hline & B & Sig T \\
\hline ch & 10.37046 & 0.0000 \\
lb & -0.48994 & 0.0000 \\
I P & 0.14459 & 0.0000 \\
ed & -0.40801 & 0.0009 \\
s & 9.51841 & 0.0000 \\
constant & 6.04154 & 0.0008 \\
\hline
\end{tabular}

The presence of children and the sex of the respondents are the strongest factors which influence the supply of hours of household production. The influence of hours of paid work of the partner has a positive, although small, effect, the level of education is now significant and has a negative effect, that means the higher the level of education the lower the hours of household production.

If the analysis is restricted to partners with children, the age of the youngest child has a significant positive effect on hours of household production. For single people the analysis shows that being female, having a low level of education and a low level of hours of paid work, have a significant positive effect on unpaid household production. The sex of the single parent together with the age of the youngest child have a significant influence on the total hours of household production. For older children living with their parents the only significant effect is being female. For single people of 65 and over being female, having a low level of education and no or few hours of paid work, have a significant positive effect on household production. Being the wife of partners of 65 and over also has a significant influence on hours of household production.

5. The demand function of labour should be extended to unpaid work, distinguishing unpaid work in the own family and voluntary work. The demand for voluntary help is important for government policies with respect to aged, disabled and sick people. If, for any reason, people can no longer do unpaid work because they are ill, too old or handicapped, they have to buy household help or pay for a hotel, a hospital, or a home for elderly or disabled 
people. Often the community assists by providing money to buy the necessary care or by furnishing care in kind. In most industrialized countries government expenses increase because more care is required for the ageing population. Governments assume that it is possible to economize on paid care in health programmes, because it can be substituted by unpaid care. People are discharged after hospitalization, assuming that unpaid care will be available at home, even if the patient is a single person. The capacity of homes for elderly or handicapped is reduced at the same time as the capacity of subsidized home help, assuming that a partner or daughter will take care of these people. However, nobody knows how much unpaid care is actually available. The connection or coherence between paid and unpaid care is not known. The same applies to the influence which the substitution of paid care by unpaid care has on labour market behaviour, on youth criminality, on the health of the entire population. Time use surveys could be the basis of the estimation of these equations.

\subsection{Summary and conclusion}

Economists have paid more attention to unpaid work in microeconomic models than in macroeconomic models. First steps in modelling unpaid work in macroeconomic models are set in a theoretical growth model with the feminization of the labour market and the intensity of household labour as extra arguments (Ertürk and Çagatay), in a model which links the formal and informal economy (Graafland) and in criticism by Plantenga and Sloep on the way labour supply is modelled in MIMIC, a micro-macro model of the Netherlands Central Planning Bureau.

Research by Knulst, Driehuis, Van der Lippe and Niphuis-Nell and myself shows that the organization of paid and unpaid work is closely connected. In section 7.6. it is suggested that unpaid work should be implemented not only in the modelling of labour supply, but also in the modelling of production, consumption, utility etc. The same arguments which plead for implementation of timpaid work in National Accounts are valid for its implementation in macroeconomic models. 
PART II

UNPAID WORK AND ECONOMIC INDEPENDENCE 



\section{ECONOMIC INDEPENDENCE: DEFINITION AND MEASUREMENT}

"While doors to education and health opportunities have opened rapidly for women, the doors to economic and political opportunities are barely ajar"

(UN Human Development Report 1995).

\subsection{Introduction}

As a child grows up it has an increasing tendency to do things by himself. The older the child gets, the more it will act without the help of older people. The child will sit, walk, eat and wash itself. School and professional education complete this process of becoming independent. The essence of independence is that one is not dependent on other people for daily care and maintenance. This applies especially to married or cohabitating women in relation to their male partners, as is argued in section 2 .

Economic independence is a prerequisite of equal rights although it is not sufficient in itself to gain an equal position for adults in fields e.g. political power, living-space, leisure, education, experience on the labour market, status, quality of work etc. What minimum income and time for care should one have to be economically independent? Who is to decide how much money and time are needed for a decent living? This minimum will differ depending the circumstances, e.g. the climate, the state of the household inventory, people's skills in household and do-it-yourself activities. In section 2 economic independence is defined as well as micro and macro instruments to measure economic independence. Section 3 explains why economic independence is more a woman's than a man's problem. In section 4 microeconomic independence of women in the Netherlands is measured, whereas in section 5 economic independence of Dutch women on a macro level is pictured. In section 6 it is argued that women's dependence has been a problem since the Middle Ages, whereas section 7 mentions resolutions of international conferences and programmes of international organizations to stimulate women's economic independence. Taking into account women's unpaid work into National Accounts will not solve this problem, as is argued in section 8 . Section 9 contains a summary and conclusion.

\subsection{Definition of economic independence}

The Dutch Equal Rights Policy Plan, which was accepted by Dutch Parliament in 1985, defines economic independence as "the situation in which all adults whatever their sex, civil status or lifestyle can build up an independent existence. In this context it means they can support themselves and take care of their daily needs. In principle this will be achieved through a growing participation in paid work and, if they are incapable to do so, through acquiring (individual) 
entitlement to benefits. The objective assumes a general participation, as general as possible, in paid work but also assumes an equally general participation in different types of unpaid work" (Ministry of Social Affairs and Employment, 1985). In short, there are two important elements in this definition. The first one is financial independence through paid work. The second one is care independence through unpaid work, which means doing domestic chores for one's own benefit and possibly for dependent children and sick persons.

In the introduction to this chapter it has already been mentioned that the definition of economic independence will differ depending the circumstances. A minimum of economic independence will be reached depending on money income, size of the family, climate, state of the household inventory, people's skills in the household and do-it-yourself activities etc. I define maximum or complete economic independence as a situation in which men's and women's working conditions are equal, and men's income distribution is the reflection of women's income distribution. Complete economic independence means that paid and unpaid work is divided equally between men and women, that women as a group not only get the same amount of paid and unpaid work, but also have the same distribution of quality of work as men. Between the minimum and the maximum a scale of varying degrees of economic independence can be distinguished. On the one hand minimum economic independence exists if individuals can support themselves and look after themselves. On the other hand maximum economic independence is the situation in which paid and unpaid work have equally been divided between men and women, a situation in which about half of the economically active population would be female and women would receive half of the country's labour income.

\subsection{Economic independence and sex}

The traditional division of labour between the sexes - the husband is the breadwinner and the wife is the housewife - means that paid labour is men's domain and unpaid labour is women's terrain. Pujol (1992) analysed that in neo-classical thinking unstated assumptions about all women are that they are:

- married, or if they are not, they will be;

- economically dependent to a male relative;

- housewives;

- unproductive in the industrial workforce;

- irrational, hence unfit to make the right economic decisions.

Pujol quotes neo-classical economists e.g. Jevons, who asserts that "there are no duties which are more important in every respect than those which a mother is bound by with regard to her own children". For Pigou the main determinant of women's labour supply is their husbands' income, although in Pigou's time a substantial proportion of women were and remained unmarried, and among those who were married, full economic support by husbands was often far from reality. Pigou advocated the prohibition of employment for mothers and 
proposed some form of state-funded "relief to those families whom the prohibition renders necessitous" (Pujol 1992, p.8 and 13). Marshall maintained that women's employment "tempts them to neglect their duty of building a true home, and investing their efforts in the personal capital of their children's character and abilities" (Pujol 1992 p.10).

In his famous 1962 article about the labour force participation of married women, Mincer asks why these married women are in the labour force, rather than asking why women's working conditions differs from men's (Mincer 1962). This ideology about women as housewives and mothers has not disappeared and still pervades economic thinking. This partly explains why economic independency is more a women's than a men's problem. Applying the definition of economic independence to financial as well as care independence, on average neither men nor women are economically independent. However, women's life income is lower than men's because:

- on average women work less years on the labour market than men

- if they work on the labour market, they work less hours than men

- averagely their hourly wage is lower than men's.

Joshi (1987) laid down her research about life income in the following graph (figure 8.1.)

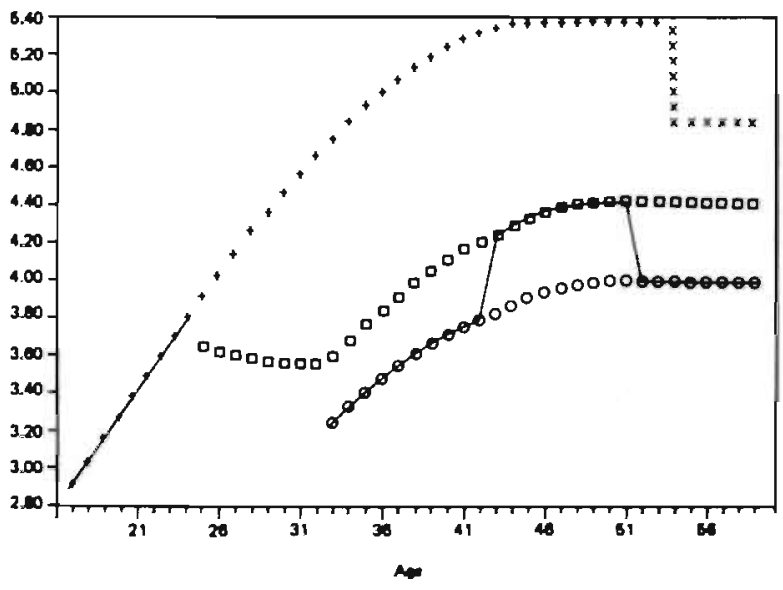

Figure 8.1. (Joshi 1987 p.177) 
The upper line represents the average annual income of men, the middle line the average annual income of unmarried women, the lower line the average annual income of mothers with children. Mothers do not work between the age of 25 to 32 and they stop at the age of 50 . Joshi estimates that life income of married English women born in 1946 was $46 \%$ lower than life income of unmarried women, because averagely mothers leave the labour market for eight years and when they return after that period, they work part-time for 12 years. Joshi attributes $40 \%$ of the loss of life income to the years the mothers had left the labour market, $36 \%$ to the years they worked part-time and $25 \%$ to the lower hourly wage (Joshi 1987 p.122-131).

Mincer and Polachek (1974) found that white American women lost $1.5 \%$, of their wage during the rest of their life for every year that they stayed out of the labour market. Dutch research of Groot, Schippers and Siegers (1988) indicates a permanent wage loss of $2 \%$ for every year outside the labour market. The loss is only $0.5 \%$ if women continue to participate in the labour market part-time instead of leaving the labour market.

Another reason why economic independence is more a women's than a men's problem is that a money income enables people to buy household servicesi and household help, as has already been mentioned. In this way men are often able to buy household help, but women cannot easily find any paid work if they miss the required labour market experience or recent professional qualifications.

Is economic independence of partners conflicting with partnership(17)? In economic literature one can find several theories about decision making in marriages. Becker developed a model in which the male specializes in paid andi the female in unpaid labour if household production functions have constant or increasing returns to scale. Becker assumes that partners have different comparative advantages. As women have a biological commitment to the production and feeding of children and are, in his eyes, biologically committed to the care of children in other more subtle ways, women will specialize in unpaid. labour. Women are not in the labour force when they have young children because their time is worth more at home. This is especially the case in countries: where women receive less schooling than men (Becker 1981 chapter 2). Becker believes that the major cause of changes in the family in the USA, like the decline of the legitimate birth rate, like the increase in divorce rate and like the growing labour force participation of mother with young children, is the growth in earning power of women (Becker 1981 chapter 11). In the utility function of the head of the family figures his own consumption and that of his "beneficiaries". 17 Partnership does not necessarily mean team productions as defined by Alchion and Demsetz (1972). Team production is production in which 1. several types of resources are used and 2. the product is not a sum of separable outputs of each cooperation resource. Although a certain form of cooperation between husband and wife will exist, this need not take the form of team productions with an inseparable production function. Assume $\mathrm{Z}=$ child care which is given by both husband $(\mathrm{H})$ and wife $(\mathrm{W})$. If child care takes the form of team production, the production function would be: $\mathrm{Z}=\mathrm{T}_{\mathrm{h}}, \mathrm{T}_{\mathrm{w}}$. Activities such as child care are nearly always done by either husband or wife, so the production function would look like: $\mathrm{Z}=\mathrm{Zh}_{\mathrm{h}}+\mathrm{Z}_{\mathrm{W}}$, as a result of $\mathrm{Z}=\mathrm{aHh}+\mathrm{b} \mathrm{H}_{\mathrm{w}}$. 
Altruism is the reason the head transfers general purchasing power to all members of his family. "If he does not care much, they don't get very much" is Nelson's criticism (Nelson 1995 p.62).

In the Barten model of demographic effects a dependent wife and children have price-like effects on the head's utility function, because the decision maker has to buy more than is necessary for his own needs. The household composition dictates how much of each purchase the head has to buy:

$\mathrm{U}=\mathrm{U}\left(\mathrm{z}_{1} / \mathrm{m}_{1}, \mathrm{z}_{2} / \mathrm{m}_{2}, \ldots . . \mathrm{z}_{\mathrm{j}} / \mathrm{m}_{\mathrm{j}}\right)$ where the $\mathrm{Z}_{\mathrm{i}}(\mathrm{j}=1 \ldots \mathrm{J})$ are household purchases of $\mathrm{J}$ goods and the $\mathrm{m}_{\mathrm{j}}$ are functions of the household composition. Having children makes ice cream, milk and sot drinks relatively more expensive and makes whiskey or cigarettes relatively cheaper. The internal workings of the family are a black box (Nelson 1995 p.63). Samuelson suggested to look at family decisions as the result of maximizing a "social welfare function" defined over the vector of member utility functions.

More recently bargaining models with divorce threat points have been developed for example by Notburga Ott (1995). In her dynamic model partners bargain about the division of unpaid work in period one because they realize that specialization in unpaid work will influence the future earning capacity of the female irreversibly in a following period. The bargaining effect may result in time

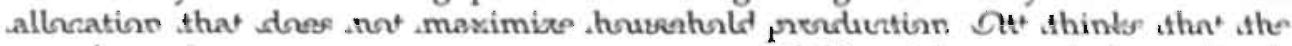
wish for a child may create a prisoner's dilemma if this wish can only be realized by a disruption in the working life of the mother and recommends policies like child care and shorter working hours for both parents (Ott 1995).

Nelson (1995) suggests a concept in which each family member is considered to be embedded in relationship both as an individual and as a person. Such a concept involves economic responsibility as well as economic independence. Responsibility in questions of financial provisioning, child care and child support, in the allocation of household tasks, in the dividing up of decision making and in the maintenance of inter-family connections. Dependence takes financial forms, physical forms (for example a dependence on someone else to do one's laundry or to feed one as a child), and developmental forms (the need of an infant for attention and bonding in order to thrive). Responsibility means that actions may be taken quite apart form personal preference. Nelson refers to Amartya Sen (1982) who has discussed the same notion of "persons-in-relations" and the contrast between "altruism" and "responsibility". Her advice is to look at the economy of marriage as involving three dimensions: living standards, agency and affiliation. Living standards refers to the welfare one gets from goods and the use of one's time. Agency is the ability of each person to recognize and promote his or her interests. Affiliation represents the need of human beings to belong and to be loved. She thinks it plausible to posit that marriages in which the spouses each explore a wider range of "doing and being" have welfare-enhancing properties that outweigh any losses from lessened specialization (Nelson 1995 p.73). 
My conclusion is that economic independence of both spouses need not conflict with partnership.

\subsection{Microeconomic measurement of economic independence}

All inhabitants of the Netherlands are entitled to a minimum subsistence benefit thanks to the National Assistance Act (Algemene Bijstandswet-ABW). This minimum is related to the legal net minimum wages. For someone aged 23 and over and living alone the law provides for a benefit of $70 \%$ of the net minimum wages. The percentage of 70 has been taken as the minimum money income below which an individual cannot live independently. A single parent receives a social benefit of $90 \%$, which has been taken as the minimum money income below which single parents cannot live independently. However, it is obvious that the National Assistance Act presupposes that the individual takes care of his/her own household chores. The benefit is not large enough to buy household services or hire a household help. People with high incomes can of course buy household help, so the higher the income, the less the need to include unpaid time in the definition of economic independence. Time use research showed that averagely a single male spends at least 19 hours a week and single fathers 21 hours a week doing unpaid work. Single females spend on average 31 hours a week and single mothers, 42 hours a week on unpaid work (see table 4.6.). In this way an income of $70 \%$ of the net minimum wages and 19 hours a week spent on household work is the minimum beneath which one cannot speak of an economically independent person. In the same way single parents need a minimum income of $90 \%$ of the net minimum wage plus the statutory childrens' benefit, and at least 21 hours a week of unpaid time for housework and child care. Table 8.1. shows the 1985 and 1990 percentages of men and wommen i earning a labour income higher than the legal minimum benefit for a single person.

In $198930 \%$ of all women aged $18-64$ and $71 \%$ of men (column 2 and 4 ) reached a minimum of financial independence by working on the labour market. If the group was restricted to individuals with a labour income $70 \%$ of all women and $97 \%$ of all men had a minimum financial independence in 1989 (column 6, and 8). Financial independence for 18-19 year old women and men is nearly the same, but the percentage of older women having a labour income equal or higher than the minimum social benefit is much lower than that of men, because many women have part-time jobs. So for women even a job does not mean financial independence. 
Table 8.1.

Financial independence (income >/ social minimum), subdivided between sexes and age groups in 1985 and 1989

\begin{tabular}{|c|c|c|c|c|c|c|c|c|}
\hline \multirow[t]{3}{*}{ Age } & \multicolumn{4}{|c|}{ All persons } & \multicolumn{4}{|c|}{ Persons with labour income } \\
\hline & \multicolumn{2}{|l|}{ women } & \multicolumn{2}{|l|}{ men } & \multicolumn{2}{|l|}{ women } & \multicolumn{2}{|l|}{ men } \\
\hline & 1985 & 1989 & 1985 & 1989 & 1985 & 1989 & 1985 & 1989 \\
\hline $18-19$ & 11 & 9 & 8 & 13 & 29 & 30 & 24 & 43 \\
\hline $20-24$ & 49 & 51 & 53 & 57 & 81 & 84 & 90 & 93 \\
\hline $25-29$ & 42 & 50 & 81 & 84 & 79 & 84 & 98 & 98 \\
\hline $30-34$ & 25 & 33. & 6 & 88 & 57 & 72 & 99 & 99 \\
\hline $35-39$ & 19 & 28 & 88 & 90 & 44 & 63 & 99 . & 99 \\
\hline $40-44$ & 20 & 29 & 88 & 88 & 46 & 62 & 99 & 99 \\
\hline $45-49$ & 16 & 24 & 82 & 82 & 40 & 62 & 99 & 98 \\
\hline $50-54$ & 14 & 17 & 76 & 76 & 41 & 55 & 99. & 98 \\
\hline $55-59$ & 10 & 10 & 59 & 56 & 42 & 55 & 98 & 98 \\
\hline $60-64$ & 3 & 3 & 25 & 16 & 38 & 44 & 97 & 94 \\
\hline total & 24 & 30 & 70 & 71 & 60 & 70 & 97 & 97 \\
\hline
\end{tabular}

Source: SCP 1993 p.168

Table 8.2. shows that the percentage of Dutch men without any income decreased by $75 \%$ and the percentage of women by $35 \%$ during the period 1977-1989. The percentage of men without a labour income decreased by only $7.5 \%$, whereas the percentage of women decreased by $20 \%$.

The preliminary conclusion from this table is that both men and women in the Netherlands make progress in economic independence.

Table 8.2.

Percentage of all Dutch men and percentage of all Dutch women aged 18-64

\begin{tabular}{|c|c|c|c|c|c|c|c|c|}
\hline & 1977 & 1981 & 1985 & 1989 & 1977 & 1981 & 1985 & 1989 \\
\hline & \multicolumn{4}{|c|}{ no income } & \multicolumn{4}{|c|}{ no labour income } \\
\hline men & 8 & 5 & 5 & 2 & 27 & 29 & 301 & 25 \\
\hline \multirow[t]{2}{*}{ women } & 60 & 49 & 46 & 39 & 70 & 65 & $63 i$ & 56 \\
\hline & \multicolumn{4}{|c|}{ income <social minimum } & \multicolumn{4}{|c|}{ labour inc.< social minimum } \\
\hline men & - & - & 30 & 29 & - & - & 3 & 3 \\
\hline women & - & - & 76 & 70 & - & - & 40 & 30 \\
\hline
\end{tabular}

Source: SCP 1993 Pp. 140,168 
Research by Sorensen and McLanahan (1987) shows the same trend for married women in the United States: the percentage of white wives without income decreased from $83.7 \%$ in 1940 to $30.6 \%$ in 1980 .

Having an income of a certain level is a minimum condition for financial independence. Sorensen and McLanahan (1987) measure the rate of economic independence by looking at the wife's share in the couple's income. They leave out the value of unpaid work. In my eyes this is a practical solution to measure microeconomic independence because on average women's money income is much lower than men's and because one can buy household services if one's money income is high enough (see also section 8.3.). They did not pay attention to care independence.

Table 8.3. shows that the percentage of Dutch wives who contributed $5 \%$ or less to the couple's income decreased from $73 \%$ in 1977 to $49 \%$ in 1989 , whereas the percentage of wives who contributed more than $45 \%$ to the couple's income increased from $8 \%$ in 1977 to $15 \%$ in 1989 .

Table 8.3.

Wife's share in couple's income (all ages)

\begin{tabular}{|c|c|c|c|c|}
\hline Percentage & 1977 & 1981 & 1985 & 1989 \\
\hline $0-<5$ & 73 & 65 & 57 & 49 \\
\hline $5-<25$ & 9 & 12 & 13 & 15 \\
\hline $25-<45$ & 10 & 11 & 16 & 21 \\
\hline $45-<55$ & 4 & 7 & 11 & 12 \\
\hline $55-<95$ & 2. & 4 & 3 & 3 \\
\hline$>95$ & 2. & 1 & 1 & 0 \\
\hline
\end{tabular}

Source: SCP 1993, p.162

The same trend has been shown for the United States: Sorensen and McLanahan (1987) report that the percentage of white wives in the United States, who contributed $50 \%$ or more to the couple's income increased from $9.2 \%$ in 1940 to $32.1 \%$ in 1980 (Sorensen and McLanahan 1987 p.667).

\subsection{Macroeconomic measurement of economic independence}

Women's labour market participation rate is often taken as a macroeconomic measure of the development of women's economic independence. However, the participation rate does not tell much about the income people earn. Therefore the goal of this section is to determine women's share in disposable income.

Labour force participation has three dimensions: the first dimension is whether a person participates or not, the second one is the number of hours the person 
participates and the third one is a measure of the quality of the work. The third step is not yet dealt with in this chapter. If men and women would have equal opportunities on the labour market, women's share in the economically active population would be about $50 \%$. Actually, women's share in the economically active population in the age group 18-64 years has grown from $28 \%$ in 1975 to $39 \%$ in 1990 , as shown in table 8.4

Women's share in disposable income is lower than the proportion of women in the economically active population. Disposable income is defined as primary income + (social benefits - social charges - tax).

Table 8.4.

Women's share in the economically active population and in disposable income

Economically active

Disposable income

population

$\begin{array}{lll}1975 & 27.7 & 20.1 \\ 1977 & 28.5 & 21.5 \\ 1979 & 29.7 & 22.0 \\ 1981 & 32.5 & 23.4 \\ 1983 & 34.1 & 24.0 \\ 1985 & 34.8 & 26.5 \\ 1987 & 37.6 & 28.3 \\ 1990 & 39.2 & 30.2\end{array}$

Sources: Statistics Netherlands (SN) (different years): Statistische Zakboeken, Sociaal-Economische Maandstatistieken, Arbeidskrachtentellingen \& Inkomensstatistieken

Women's share in total labour income is lower than the proportion of women in the economically active population. Why is this so? The first reason is that registered unemployed people are counted as part of the economically active population. Women's standardized rates of registered unemployment are higher than men's in EC countries, with the exception of Luxembourg and the United Kingdom (OECD 1988 p.142). So proportionally more unemployed women than men are counted in the active population. If the criteria for unemployment are seen less strictly, the gap between women's and men's unemployment becomes even bigger as is shown in chapter 5.5.4.

The second reason why women's share in total labour income is smaller than the proportion of women in the economically active population is that more women than men work part-time. In the OECD Employment Outlook 1988 the proportion of female part-time employment in EC countries is three to fourteen times higher than male part-time employment. In the Netherlands in $199265 \%$ of all women worked part-time, compared to $8 \%$ of all men (Ministry of Social Affairs 1994). 
The third reason why women's share in total labour income is smaller than the proportion of women in the economically active population is that the average wage rate for women is lower than the average wage rate for men. This is illustrated in table 8.5.

Table 8.5.

Hourly wages of women and men in Dutch Guilders in 1989 per economic sector

\begin{tabular}{|c|c|c|c|}
\hline & women & men & women $/ \operatorname{men}(\%)$ \\
\hline Industry & 15.60 & 21.57 & $72 \%$ \\
\hline $\begin{array}{l}\text { Services } \\
\text { of which: }\end{array}$ & 16.04 & 21.64 & $74 \%$ \\
\hline - commerce/hotel and repairs & 13.05 & 19.26 & $68 \%$ \\
\hline transport etc. & 16.82 & 20.36 & $83 \%$ \\
\hline - banking/insurance & 15.82 & 23.23 & $68 \%$ \\
\hline - other services & 17.28 & 22.91 & $75 \%$ \\
\hline
\end{tabular}

Source: SN - halfyearly statistics of earned wages

Women earn less than men in all countries worldwide. However, for Australia and most European countries as well as for the United States statistics of hourly earnings of manual workers in the manufacturing industry reveal a widespread increase in relative fernale earnings since the nineteen sixties (OECD 1988 p.170; Blau and Ferber 1986 p.181; Willborn 1991 p.2). Explanations for this wage gap and its decrease differ from country to country. Part of the wage gap can be explained by differences in human capital (education, experience, on-the-job training), occupational and functional sex segregation, but also discrimination of women plays a role (Bielby and Baron 1984; Blau and Ferber 1986; Schippers, 1987; Michael et al. 1989; Willborn 1991). In literature several policies have been followed or suggested to eliminate the wage gap including equal employment opportunities, affirmative action and comparable worth. However, as the wage gap is a complex problem, it is not clear which policy is best (Michael et al. 1989). This subject will be dealt with again in chapter 9 .

In the 1995 United Nations Human Development Report an index to measure gender equality was introduced: the Gender-related Development Index (GDI), This index measures the same basic capabilities as the Human Development Index (HDI) but takes note of inequality in achievement between men and women. The HDI contains three indicators: life-expectancy, educational attainment and real Gross Domestic Product. To construct the GDI each of these three components is expressed in terms of the female value as a percentage of the male value. Then the HDI is multiplied by this simple average female-male ratio. GDI has been constructed for 130 countries. The report concluded that:

1. Gender equality does not exist anywhere. Gender equality ranks from 0.919 (Sweden) to 0.169 (Afghanistan). The Netherlands are fourth on the HDIranking, but twentieth on the GDI-ranking, with an index of 0.851. Life 
expectancy of Dutch women, adjusted for biological differences, is good, their literacy is the same as that of Dutch men, but women's share in earned income is only $25 \%(18)$

2. Gender equality does not depend on the income level of a society. Countries showing a marked improvement in their GDI- ranking over their HDIranking have invested in the education and health of their people, irrespective of gender, whereas their gender equality in income has become bigger than average.

3. Significant progress has been achieved over the past two decades. The Report calculated the GDI in 1970 and in 1992 for 79 countries. The average GDI showed an improvement of $48 \%$. Developing countries showed an improvement of $62 \%$, industrialized countries a rise of $28 \%$.

\subsection{Economic independence as a target of economic policy}

Economic independence of women was already a problem in the Middle Ages (Bücher 1909). Bücher, an economist belonging to the Historical School of Economic Thought, studied women's position in German society in the Middle Ages. Because more men than women died because of warfare, dangerous trade travels, diseases such as the plague, society counted more women than men from the age of 20 (Bücher p.8). These single women earned their living by means of a variety of professions: wool and linen weavers, furriers, girdlemakers, shearers, tanners, goldsmiths etc. In short women were not excluded from any profession which they could master with their physical abilities (Bücher p.19). Sullerot (1969) mentions that in France women were not excluded from professions until the sixteenth century when guilds began to restrict the rights of widows and to exclude other women, with the result that in the eighteenth century hardly any women could be found in handicraft (Sullerot 1969 pp.57; 65-70). Other solutions for single women were to enter a convent or a beguinage (Bücher pp.24-35). Because more products were made and used at home, in which wives played an important role, the dependency of wives was not a problem (Rathbone 1924 p.3). When the guilds disappeared and the industrial revolution began, the wives' role in production became smaller. The responsibility for the support of the family was thrown on to men, especially after child labour in mines and industry had been banned and female labour restricted (Rathbone 1924 p.7).

Economic independence was an important item in the first emancipation wave in the western world in the beginning of the twentieth century, which dwindled when women got the vote. After World War II economic independence became an important issue in the emancipation of women. Since the end of World War II all Dutch Governments have strived after five objectives of economic policy: economic growth, a stable balance of payments, stable prices, full employment and an acceptable income distribution. In 1988 Dutch Government sought advice

18 The report mentions that women's share in earned income has been calculated based on data "for the latest available year" but there is no mention of the year in question. This explains the differences from the shares mentioned in table 8.4 
of the SER (Sociaal Economische Raad - Social and Economic Council) whether to add a sixth one to these five objectives of economic policy: economic and care independence of all adults. The SER regarded this target of women's economic independence to be of broader purport and of higher hierarchy than the socio-economic targets (SER 1988).

\subsection{Resolutions of women's international conferences}

In 1985 the International Women's Conference in Nairobi recommended that: "The renumerated and, in particular, the unrenumerated contributions of women to all aspects and sectors of development should be recognized and appropriate efforts should be made to measure and reflect these contributions in National Accounts and economic statistics and in the gross national product. Concrete steps should be taken to quantify the unrenumerated contribution of women to agriculture, food production, reproduction and household activities" (Waring 1988 p.307; UN 1986, section 120).

In 198728 international women's organizations, e.g. trade unions, human rights, anti-slavery organizations, urged the United Nations Commission on the Status of Women to make a priority of the above-mentioned recommendation and to coordinate the efforts made by several international organisations, including the ILO, to measure the economic contribution of unpaid work to society. They point out that investment in training, credit facilities and appropriate technology to subsistence farmers in Africa (a majority of which are women) is not given because their contribution is unassessed and unrecorded. They argue that the invisibility of women's work also has serious implications in the area of social protection, as the number of one-parent families increases. In most cases one-parent families are headed by female homemakers who have no earnings and qualify for social security benefits only as dependent of "protected" paid workers (United Nations 1987 a).

In a report of the Dutch Government on concrete measures to execute the recommendations of the international 1985. Nairobi Conference (Netherlands Parliament, Second Chamber stuk $21505 \mathrm{nr} .2,1990$ ) no mention has been made of measures to register the unrenumerated contributions of women to agriculture, food production, reproduction and household activities in National Accounts, econornic statistics and in the gross national product. Neither have any concrete steps been mentioned in an Ecosoc-resolution (UN 1990) about the execution of the Nairobi Forward-looking Strategies.

In 1992 a report of a high-level group of experts of the Organization for Economic Cooperation and Development (OECD) stated that the social and economic value of non-market forms of activity should be acknowledged. The OECD argued that domestic production and voluntary or community work is essential to keep societies and their supporting economies functioning. Structural trends, such as the state retrenchment in the provision of some health and welfare services, and 
the growing demand for services to the elderly, are increasing the pressure on unpaid workers. Because family and community services have mainly been provided by women, especially home-based women, they have largely remained invisible and undervalued. Women's increasing labour market participation has reduced the pool of people able to fulfil these tasks. Without a significant revaluation of these activities participation in these tasks is unlikely to increase (OECD 1992 p.26).

In 1993 the European Parliament adopted a resolution which included a request to the European Commission to make comparative studies about the contribution of household work to Gross National Product and to make recommendations about the evaluation and recording in GNP of member states. It was argued that economic evaluation of household work is important:

- to discuss the position of unpaid workers in social security;

- to take into account unpaid activities in fiscal policy;

- for financial compensation after divorce;

- to have the possibility to do paid work after a period of caring for children;

- for claims for inheritances;

- for claims for damages

(European Parliament 1992; Eurolink Age July 1993 p.7).

The central message of the 1995 United Nations Human Development Report was the necessity to engender human development.

\subsection{National Accounts and economic independence}

The goal of the statements and resolutions mentioned in section 8.7 is acknowledgement of unpaid work and its position in social security, fiscal policy and some legal matters.

Waring (1988) argues that if unpaid work would be registered in National Accounts "every decision made by government would be influenced in a profound way". She mentions that per capita Gross Domestic Product would change markedly. Furthermore she mentions that "the needs for credit facilities, fertilizers, seeds would be clear for subsistence agricultural producers. The needs for training and retraining the unpaid work force would receive attention as a policy priority. Unpaid workers could make a realistic claim on the public purse as opposed to being condemned to "welfare" (Waring 1988 p.285).

Economic or financial independence is not the issue of the statements and resolutions of women's organizations and international conferences mentioned in section 8.7. Waring (1988) explicitly mentions in her book that "payment or replacement is not the point of issue" (Waring 1988 p.277). Acknowledgement of unpaid work in social security, for example in old age benefits, benefits for one-parent families, maternity leave, child and family benefits, provisions in case of illness and disablement (European Parliament 1992; OECD 1992), may 
improve the financial situation of men and women doing unpaid work if faced with calamities. More attention for the needs of training and retraining the unpaid work force may improve their chances on the labour market, but these measures will not lead to equality or economic independence of paid and unpaid workers. Acknowledgement of unpaid work in the National Accounts could even be role affirming because one can use this as an argument to keep women in their place at home. However, taking into account the value of unpaid work in National Accounts does not lead to (more) economic independence. The unpaid worker remains financially dependent on paid workers or the State.

Several attempts have been made to influence the financial position of unpaid workers directly. These attempts will be dealt with in sections 9.2. and 9.3.

\subsection{Summary and conclusion}

Economic independence is defined as the situation in which all adults can build up an independent existence. It consists of financial independence plus care independence. Financial independance is acquired by doing paid work and if persons are incapable to do unpaid work by individual entitlement to benefits. Care independence is acquired by doing unpaid work for one's own benefit and for dependent children and sick people. Economic independence can vary from a minimum to a maximum. For the Netherlands a minimum is defined as having an income in conformity with the National Assistance Act (Algemene Bijstandswet-ABW) ( $70 \%$ of legal minimum wages) and being able to do household chores for one's own benefit and dependents. In 1989 3\% of Dutch men and $40 \%$ of Dutch women aged 18-64 with a labour income earned less than this minimum.

A maximum is defined as a situation in which men's and women's working conditions are equal, and men's income distribution is the reflection of women's income distribution. In $19892 \%$ of Dutch men and $39 \%$ of Dutch women had no income at all. In 1990 women's share in disposable income was $30.2 \%$.

The 1995 United Nations Human Development Report concludes that gender equality does not exist anywhere. The Report uses a Gender-related Development Index which measures gender equality in life-expectancy, educational attainment and income. As early as the Middle Ages economic dependence of women was pointed out as a social problem. In Resolutions of International Women's Conferences, statements and publications of the OECD, the EC and other publications the absence in National Accounts of women's contributions to the economy by doing unpaid work, is mentioned.

The conclusion of this chapter is that although progress has been made, economic independence for women throughout the world is still far away because paid and unpaid work are asymmetrically distributed over men and women. In chapter 9 ways and means to improve women's economic independence will be analysed. 


\title{
9. ECONOMIC INDEPENDENCE AND UNPAID WORK
}

\author{
"Would you tell me, please, which way I ought to go from here?" \\ That depends a good deal on where you want to get to" said the Cat. \\ (Alice's Adventures in Wonderland, Lewis Carroll 1865)
}

\subsection{Introduction}

In the preceding chapters it has become clear that unpaid work contributes much to general and individual welfare. Unpaid work represents the "care" component of economic independence, the other component of economic independence is "financial" independence. In chapter 8.3 the asymmetric contribution of unpaid and paid work to economic independence has been analysed. On the one hand renumeration of paid work makes it possible to buy household services; paid work is hardly a hindrance to do unpaid work. On the other hand the renumeration of unpaid work is in kind (food, housing, clothes), it does not enable people to buy whatever they wish; doing unpaid work is an obstacle for paid work, because time spent on unpaid work does not give the necessary labour market experience and on-the-job training.

In this chapter several solutions will be reviewed for the dilemma of on the one hand the valuable contribution of unpaid work to general and individual welfare and on the other hand the economic dependence which unpaid work entails. The organization of paid work and welfare is an important item for the solution of this dilemma. Therefore in section 2 a typology of welfare states and their solutions for a combination of paid and unpaid work is given as well as three types of labour market participation of women. In section 3 "wages for housework" and in section 4 a negative income tax or a basic benefit are suggested as a solution for women's economic independence. If these suggestions are not a proper answer to this problem, which way could we go then, is the question dealt with in section 5. In section 6 the development of equal rights policies and attitudes in the Netherlands from 1975 on are described. Finally in section 7 three sets of policies are described to ensure an equal division of paid and unpaid work over men and women. Summary and conclusion are given in section 8 .

\subsection{Welfare-systems in Europe}

Esping-Andersen distinguishes three systems of the welfare state: the liberal, the conservative corporatistic and the social-democratic welfare state (EspingAndersen 1992). Although the division of unpaid work over men and women is not explicitly mentioned, the characteristics of the three systems are of interest for this subject also because the labour market participation of women, the way the tax system, social security, pensions, and social provisions are organized differ greatly. Pure examples of the three systems do not exist in reality, welfare-state variations are not linearly distributed, but clustered by regime-types. 
1. In one cluster we find the liberal welfare state, in which means-tested assistance, modest universal transfers, or modest social insurance plans predominate. Entitlement to benefits is often associated with stigma. The role of the government is minimized. Governmental help is restricted to cases where the market or the family fall short, to people who cannot help themselves, mainly the poor, widows or one-parent families. It is thought that the market mechanism is the best mechanism to ensure a maximum welfare. Labour market participation of men and women is a matter of course, but practically no allowance is made for care for children and elderly people. Social security benefits are modest and means-tested. The United States of America, Canada and Australia are archetypal examples of this model.

2. In the conservative corporatistic welfare state family and church are very important. Private insurance and occupational fringe benefits play a marginal role. Social insurance typically excludes nonworking wives and family benefits encourage motherhood. Day care and similar family services are underdeveloped. Labour market participation of women is low. Austria, France, Germany and Italy are clear examples.

3. The most salient characteristic of the third cluster, the social-democratic welfare state, is its fusion of welfare and work. Not equality of minimal needs is pursued, but equality of the highest standards. The public sector is large. Social security, provisions for children and elderly people are legally arranged. Social benefits are universal and as a rule independent of other income. Child care is arranged for by the Government, is of good quality, available for all children and subsidized by the government. Paid parental leave is available for parents with young children. Tax and social security have been individualized. Labour market participation of women is high. On the one side the right to work has equal status to the right of income protection. On the other side the enormous costs of maintaining a welfare system based on solidarity and universality means that it must minimize social problems and maximize revenue income. The Nordic countries are examples of this type of welfare state.

Financing a welfare system with high social security benefits and good social provisions depends on the percentage of people participating in the labour market. Several European countries try to reform their social security and social provisions in the way of the liberal welfare state, because the costs of social security are very high.

What type of welfare state is best for women's economic position? To find an answer we will look at their labour market position and the GDI-ranking (see section 8.5) in the 1995 United Nations Development Report.

Labour market participation of women is a reflection of the organization and division of unpaid work. Eurostat (as shown in figure 9.1.) distinguishes three models of labour market participation of women in different stages of life which partly correspond with the above given classification of welfare states. 
Participation rate of women according to age in 1990

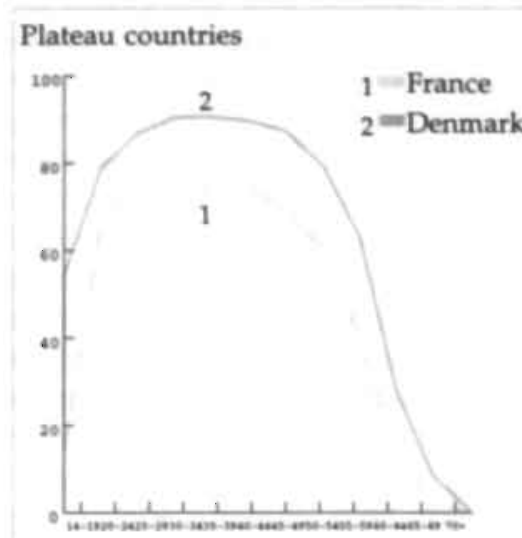

M-countries

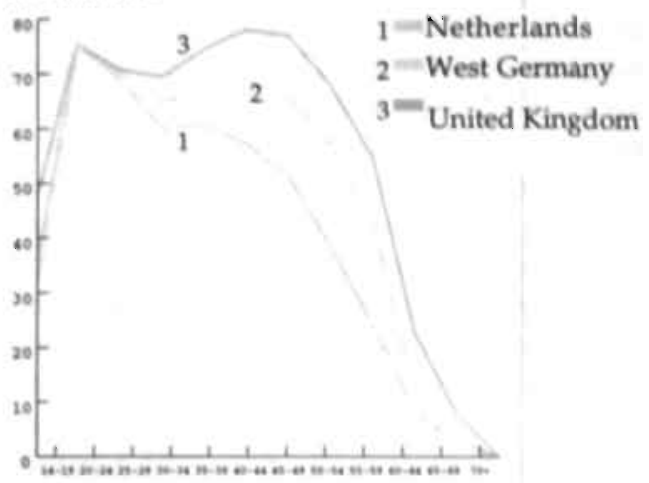

Weak left peak countries

Sharp left peak countries
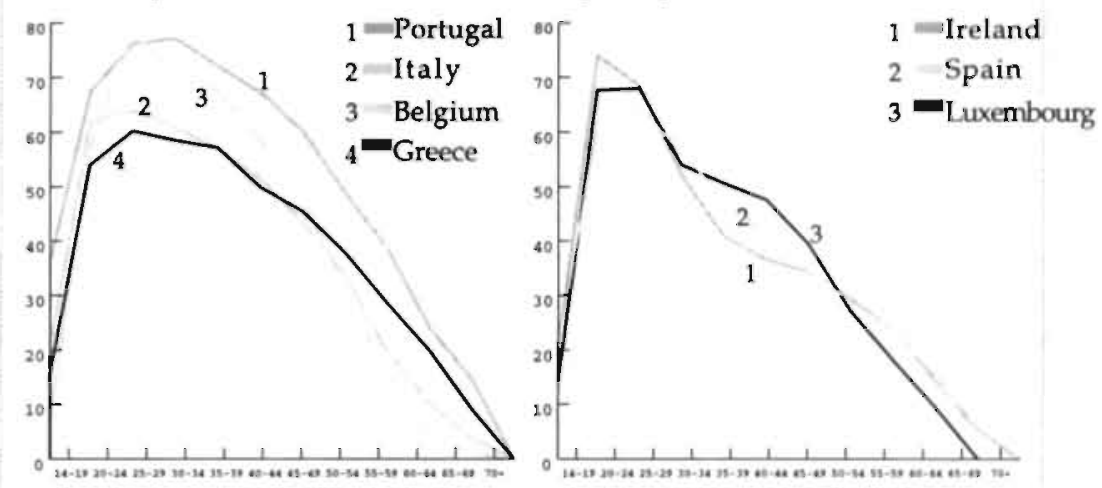

Figure 9.1

Source: Ministry of Social Affairs 1995 p.44

In so-called "plateau countries" women participate in the labour market in all stages of life in the same way as men do. This is made possible because much child care and provisions for elderly people are available. In figure 9.1. France and Denmark are plateau-countries. These are also social-democratic countries with a large public sector. 
In "M-countries" women disappear from the labour market to care for young children or they work part-time. They re-enter the labour market when their children get older because provisions for elderly people are taken care of by the government, so they do not have to take care of their parents. In figure 9.1. the Netherlands, West Germany and the United Kingdom are examples of this type of country although they do not belong to the same type of welfare state.

In "peak-countries" mothers leave the labour market when their children are born and they do not return to the labour market when their children get older, because parents have to be cared for. Government leaves all care arrangements for children and elderly people to the private sector. It goes without saying that married women look after their children and their parents. In countries with a sharp peak in the labour market participation, mothers stay on the labour market as long as grandmothers are fit enough to look after their grandchildren. Examples are Ireland, Spain and Luxembourg. In countries where the peak in the labour market participation is weaker, some child care is available. Portugal, Italy, Belgium and Greece are examples of this type of arrangements (Ministry of Social Affairs 1995 p.44; EC nr. 36 1991).

In the GDİ-ranking of the 1995 United Nations Development Report Sweden, Finland, Norway, Denmark and the USA are among the first ten countries. The United Kingdom, Italy, Belgium and the Netherlands are among the second ten countries, whereas Greece, Ireland, Spain and Luxembourg are at the tail end of the countries ranking from 21 to 35 .

It turns out that the Nordic countries are first regarding the economic position of women: the female labour market participation is plateau-shaped, their GDIranking is among the first ten. So one can conclude that a social-dennocratic structure of welfare seems to have a positive influence on women's position.

In the next sections policies to improve women's economic position will be reviewed.

\subsection{Wages for the housewife}

Around the turn of the twentieth century the question of a wage sufficient to be able to support a family, or family endowments, was discussed in industrialized countries. In France in 1890 family allowances were started by the Railway Companies, followed by the Mining Companies (Rathbone 1924 p.193). In Germany in the first decades of the twentieth century Zeiss, Krupp and other large firms paid allowances to families in addition to wages. In Belgium family allowances were introduced in the Charlero region in 1915 and in the Liège region of in 1922.

According to Rathbone (1924) about the same development could be found in the Netherlands, Austria, Czecho-Slovakia, Switzerland, Denmark, Sweden, Spain, 
Australia and New Zealand. In the Netherlands feminist organizations opposed the system of family allowances because they thought that "equal pay for equal work" should be the rule. Their endeavours led to a policy of a uniform living wage, sufficient to support a family, and comparatively luxurious for the childless workers (Rathbone 1924 pp.227-229).

In 1910 a resolution was adopted by the international Women's Conference in Copenhagen for an insurance to give mothers a benefit in case of pregnancy and confinement in order to fulfil her duties as a mother. (Wibaut 1976, p.78). In England in the nineteen twenties a discussion was started about a wage for mothers payable by the State. The English labour economist, Beatrice Webb, was of the opinion that every person should be entitled to a minimum income. A State Child Fund should pay for the costs of living of children (Rathbone 1924 p.165).

Rathbone (1924) pleaded for a family endowment in order to abolish child labour and labour of mothers. She points out that "there is no money renumeration for the mother's task, no guarantee of her maintenance while she performs it, no consequential relationship recognized by society between the quantity and quality of her product and the quality of the tools and materials which she has at her disposal" (Rathbone 1924 p.65). She concludes that "the soundest form of direct provision for mothers would not be a flat-rate allowance, but a sum on account of each child" (Rathbone 1924 p.297).

In Sweden ideas about labour market participation of women got priority over ideas of wages for the housewive. In 1934 Gunnar and Alva Myrdal published a book "Crisis in the population question", in which they pleaded the right for working women to have children. In 1939 a law was introduced which forbad. the dismissal of women because of marriage, pregnancy or confinement (Gustafsson 1984 p.136). Notwithstanding this early beginning of a family policy which favoured working women, a fierce debate was held in Sweden in the nineteen seventies about the role and status of housewives. Feminist Eva Moberg did not favour the idea to augment the status of a housewife by giving her a wage or benefit. In her view a wage or benefit would consolidate the role of the housewife. In her ideas the housewife-system should be abolished by creating crèches, professional household services, separate taxation for husband and wife, more part-time jobs also for men etc. Men should be obliged to do their own household work and parents should be entitled to a temporary benefit for the care of their children (Moberg 1968).

In the nineteen seventies women in Italy and England asked "wages for the housewife". In Italy Mariarosa della Costa (1972) influenced women's organizations and pointed out that women are the heart of societal production because they produce the real manpower. "Women are the slaves of the wage slave and her slavery assures the slavery of her husband". For that matter Della Costa herself thought that housewifery should vanish. 
In England women's organizations and unions fought British Government who wanted to shift payment of "family allowances" from the wife to the husband. This intention gave rise to a debate about wages for household work. This discussion about wages for housework spread to other countries.

In the Netherlands publications by Galinka Ehrenfest (Ehrenfest 1972; 1979) on a wage for the mother and by myself on payment for household work (Bruyn-Hundt 1973) were the starting point of much discussion. In Ehrenfest's ideas care of children was the main reason to give mothers a wage. A child is entitled to good care. The wages should encompass the costs of consumption of the child plus a wage for the caretaker. The sum should be high enough to guarantee the economic independence of the caretaker. In order to prevent that too many children would be born, Ehrenfest wanted to restrict this compensation for costs of consumption to two children. The wages should be given to the mother for a period of 10 to 15 years after the birth of the child. The wages should decrease the older the child gets, because the mother could gradually return to the labour market. Compensation of household work for adults should be arranged between the adults and should not be part of the wages for the mother. Ehrenfest wanted to finance the wages for mothers via social security for which all inhabitants had to pay a premium (Ehrenfest 1972; 1979).

At that time I was of the opinion that women and men should be rewarded for their unpaid work, care of children included. Unpaid work guarantees that a new generation grows up and that children and adults are cared for. Because women do more unpaid work than men, in practice women would benefit more from wages for unpaid work than men. The wages would depend on the magnitude of the caretaking task, which could for example be measured by taking the number and ages of the persons being cared for. This implied that the wages would decrease as children grew up. I wanted to finance the wages for unpaid work via a small increase in indirect taxes. In the beginning tax proceeds would not be sufficient, but thanks to a growing national income all unpaid hours of labour could be rewarded at the level of legal minimum wages after a period of about 30 years. Local government could be the employer of the unpaid worker (Bruyn-Hundt 1973). At a later stage I abolished this idea of wages for unpaid work.

The Advisory Council on Government Policy - WRR (Wetenschappelijke Raad voor het Regeringsbeleid), an important advisory body for the Dutch Government, published a paper and made calculations about a wage for mothers (WRR 1981, section 6.4). The WRR proposed to give mothers a full benefit during five years after the birth of a child, whereas in the subsequent 10 years the benefit would decrease little by littly to zero. Four variants were assumed: the benefit could either be of the same level as benefits provided by the National Assistance Act (Algemene Bijstandswet - ABW) or of the level of the legal minimum wages for adults. These two variants were combined with two possible changes in labour market supply of mothers. In both variants mothers with a full benefit were assumed not to participate at all, whereas for mothers with a decreasing 
benefit two different participation grades were assumed. The result could be a reduction of 13,000 labour years or an increase of 4,000 labour years. The WRR estimated the costs at 6.3 to $8.7 \%$ of Gross National Product. The benefit would be financed via social security premiums which all inhabitants would have to pay. The economic consequences of the benefit were simulated in a macroeconomic model. The simulation indicated that in all four variants wages and prices would rise as a consequence of higher social premiums and that economic activity would decrease leading to a lower consumption level. Unemployment would decrease in the variant with benefits at the level of the National Assistance Act and a lower labour supply, whereas unemployment would increase in the other three variants. Income would be redistributed from high to low incomes, from households without children to household with children (WRR 1981 p.211).

What were the arguments to give mothers or housewives a wage? The arguments in this debate were that invisible household work would become visible by paying a wage, housewives would become economically independent, wages for household work would be a guarantee for better child care, income distribution between individuals would become more equal, birth and upbringing of a next generation, important not only for parents but for the whole society, would be guaranteed and national income accounts would be more exact (Grotenhuis 1980; WRR. 1981 and 1983; Bruyn-Hundt 1985).

In 1978 I abolished the idea of a wage for housewives. Specializing in unpaid work is a pitfall for economic independence, even if the mother or the housewife receives wages during a certain period:

1. In all proposals wages are low: the minimum level of Social Assistance or the legal minimum wages. This is because wages of household staff on the market are low. A second reason is that society is not willing to finance high incomes for mothers or housewives.

2. In all proposals wages are temporary. Wages are decreased or stopped as soon as children grow up. This implies that the mother is obliged to return to the labour market at the age of 40 or 45 years if she wishes to maintain her financial independence. In the period the mother stays at home, her professional training becomes obsolete and she does not gain labour market experience (see chapter 8.3).

3. The unequal distribution of paid and unpaid labour over the sexes would continue. Women's short term financial position would be improved by paying her wages, but her long term position on the labour market and her financial position will never be the same as men's.

4. In as far as a wage for housewives is proposed, the contribution to unpaid work of men, single women, children and elderly people is neglected. This does not seem just.

5. The burden of collective expenses would become higher and the price of labour on the labour market would increase. This means a negative impuls for the growth of employment.

6. Labour market participation of women would be discouraged. Research on the elasticity of female labour supply shows that female labour supply 
elasticities are large both in absolute terms and in relation to male elasticities. The elasticity of hours of work with respect to exogenous income is negative and rather small (Killingsworth and Heckman 1986 p.185 and 190).

Therefore I reject the idea of a wage for housewives.

\subsection{Negative income tax or a basic income}

In the nineteen sixties the economists James Tobin and Milton Friedman suggested that a negative income tax would be a cheaper and more humane method to give welfare to those who needed support (Samuelson 1973 p.810). Families who come below a certain level of income because of unemployment, sickness, disablement etc. would receive a government benefit of the Internal Revenue Service which guarantees a minimum level of subsistence. The negative income tax would diminish if there are private earnings, but the percentage of reduction would leave enough incentive to accept paid work. In Samuelson's illustration this percentage is 50 (Samuelson 1973 p.811). Negative income tax would be a great improvement over welfare programmes that deprive people of all assistance the moment they get a job, even a miserable one, because the marginal rate of taxation is $100 \%$.

The idea of a negative income tax resembles Robert Theobald's (1976) idea of a "guaranteed" income. Theobald's prognosis was that scarcity of goods would vanish because of automation of production. For the same reason jobs would become scarce. In Theobald's idea a guaranteed income would enable some people to produce goods and services ("consentives") without making profits, while other people would produce goods and services for the market ("marketives").

The difference between negative income tax and a basic income is that the basic income does not diminish if other independent income increases. It is an individual incone (Geleynse et al. 1993 p.54).

In the Netherlands the idea of a basic income is still a subject of discussion. Several times The Advisory Councill on Government Policy for example advised Dutch Government to consider a basic income as an alternative for the complex social security benefit system (WRR 1981; 1983; 1985). In 1992 the Central Planning Bureau published three long-term growth scenarios. In one of these scenarios a negative income tax is taken as an alternative for income maintertance. In 1994 Gelauff and Graafland of the CPB simulated the effects of a negative income tax of $50 \%$ of legal minimum wages for all people except children and students. At the same time benefits of the social security system in the event of disability and unemployment should be abolished as well as social assistance given by government. Social benefits for people of 65 years and over are reduced in such a way that the rise in net income from the negative income tax is just offset, so that their net income does not change. Legal minimum wages are adapted in a similar 
way. Income tax is changed: basic income substitutes the basic allowance in income tax, whereas the transferability of the basic allowance is abolished. A flat tax rate is introduced to prevent very high marginal tax rates for high income groups and in such a way that budgetary neutrality is obtained. Unions and employers" organizations are supposed to reinsure the loss of disability benefits by $75 \%$ or by $50 \%$ and the loss of unemployment benefits by $10 \%$. In the $75 \%$ variant flat tax rate turns out to be $53 \%$ and in the $50 \%$ variant it turns out to be $51.5 \%$. In simulations with the MIMIC model private production and private employment decrease, unemployment and taxes as a percentage of national income increase. Net real income of employed breadwinners and single people improve, but net real incomes of unemployed and elderly people decrease.

The authors conclude that on the one hand a negative income tax would initiate a strong reduction in unemployment by stimulating the willingness to accept jobs. On the other hand it causes a large fall in labour supply as partners become less inclined to participate in the labour market. The fall in labour supply exceeds the fall in unemployment, hence employment is also reduced. The negative income tax will cause a strong financial loss for people completely dependent on a benefit income although their number will be substantially smaller because of the reduction in unemployment (Gelauff and Graafland 1994 pp.239-259).

Negative income tax or a guaranteed or basic income is in my opinion not a good solution to guarantee the economic independence of unpaid workers. If the negative income tax or basic income is considered a family benefit, the unpaid worker does not receive anything if the income of the (main) breadwinner is high enough. In this case the magnitude of the benefit depends on the income of the partner. But even if the benefit is given to each individual adult, it will always be a minimum income, which will only bring a minimum of economic independence. A basic income above the minimum would discourage individuals to work on the labour market and would increase collective spending and taxation, because more individuals than before would be entitled to a benefit. The outcome of the Gelauff and Graafland simulations is very clear: if a basic income is introduced female labour supply falls by over $40 \%$. The immediate necessity to earn an income on the labour market diminishes, so more women specialize in unpaid work. But unpaid work does not bring labour market experience, so in the long run women are worse off in case of a divorce or the death of the breadwinner. More women become dependent on a minimum income or on the breadwinner's income with small chances of improving their own lifetime income to a level above the minimum.

It would be interesting to know the results of a simulation with slightly different labour supply elasticities. Because Gelauff and Graafland (1994) use the malechauvinist model, elasticities of breadwinners, single people and one-parent households are supposed to be zero, whereas the own wage elasticity of partners is estimated at 1.0 and elasticity of breadwinner income at -0.2 (Gelauff and Graafland 1994 p.103). I wonder whether a male-chauvinist model is realistic for a long term prognosis as a growing number of fathers want to share in the joy of 
raising children by doing less paid and more unpaid work (Ministry of Social Affairs 1995 p.31).

\subsection{Unpaid work: a pitfall}

If wages for housework or a basic income is not a good solution to combine paid and unpaid work in such a way that economic independence of women equals that of men, what should be done then? It can be concluded that there is a big difference between the labour market positions of men of women and therefore their financial independence is also far from equal (EC 1993). Which way are we to go to ensure equal economic positions for women and men?

The 1992 OECD-report "Shaping structural change: the role of women" concludes that structural changes in the organization of paid and unpaid work are necessary in order to utilize women's capacities and abilities for econonnic growth and social development. The OECD thinks that the so-called "social contract" should be renewed. This social contract has two components: the "sex-contract", which supposes that women take the responsibility for care of home and children and that men are the breadwinners and the "labour contract" between employer and employee which encourages the division of labour between men and women by treating all employees as full-time breadwinners. This "social contract" does no longer fit the social and economic reality, which supposes that women can participate in the labour market and take the responsibility for care of home and children at the same time. This situation leads to stress for individuals and families, less care for elderly people, increase of one-parent families, sickness-leave and turnover of staff.

People consider the existing division of labour between men and women a "natural" one, as something that goes without saying. It is a matter of course that women bear the responsibility for child care and household and men are responsible for an income sufficient to support a family. This is a psychological and sociological obstacle for equal positions of men and women. Unpaid work in itself is not an obstacle, but its unequal distribution is a barrier for women to obtain a better position in society. In industrialized countries two-thirds of womer's total working time is spent on unpaid work and one-third on paid work. For men these shares are reverse (UN Human Development Report 1995).

Men's and women's contributions in paid work are becoming more equal in industrialized countries because the labour market participation of women is increasing. The distribution of unpaid work is also becoming more equal, mainly because women have decreased their hours of unpaid work (UN Human Development Report 1995 p.93/94). For men it is difficult to do their share of unpaid work because they are supposed to have a full-time paid job. During the period young children are growing up, the amount of unpaid work is so huge that combining at full-time paid job and half of the family's unpaid work in the Netherlands would lead to total working hours of at least 65 hours a week (see 
table 7.1.). It can be concluded that equal sharing of unpaid work is impossible without a change in the organization of paid work. Otherwise the burden of total working time will become too heavy. There are big differences between (European) countries in the way paid labour and welfare are organized.

\subsection{Equal rights policy and attitudes in the Netherlands since 1975}

Changing the positions of men and women in society is sometimes thought to be more a question of changing attitudes, of changing mentality than a question of policies. In my view policies and attitudes influence each other.

Policies for an equal distribution of paid and unpaid work can contribute to a process of change. The announcement of a new policy by government or political party, trade union, church or any other organization may be the start of a public discussion. A public discussion may change people's attitudes; things that used to go without saying, are no longer taken for granted. Changing attitudes in their turn may contribute to the introduction of legal or other measures. In this way there is an interaction between (legal) measures and attitudes, they influence each other.

Fayjal. rights and nqpartunities, for. women have heen part of the Netherlands. Government's policy since 1974. In 1977 a Junior Minister was appointed responsible for the coordination of these policies. This Junior Minister has his own civil service machinery in the Ministry of Social Affairs and Employment. To coordinate ministries' equal rights policies an Interministerial Coordinating Committee on Equal Rights has been set up. An independent governmental Equal Rights Advisory Council has been installed. The directives of the European Community on equal pay and equal treatment on the labour market and in social security have resulted in new legislation. Financial support has been given to a number of experimental training projects for women returning to the labour market. Taxation and social security legislation have been altered to ensure a more equal treatment of married women and to diminish breadwinners. facilities. Since 1980 a specific policy on equality in education is conducted. A policy to combat sexual intimidation has become part of equal rights policy. Maternity leave has been extended with four weeks. An unpaid parental leave of 20 hours per week during 6 months for both parents has been introduced. Parttimers have become entitled to the legal minimum wage.

In the same period 1975-1990 attitudes towards the role of mothers changed considerably in the Netherlands. Table 9.1. shows that a rising percentage of the Dutch population approves of mothers' labour market participation and paid child care. 
Table 9.1.

Attitudes towards child care (in percentage of total population)

\begin{tabular}{lcccccc}
\hline & 1965 & 1970 & 1975 & 1980 & 1985 & 1991 \\
\hline $\begin{array}{l}\text { Objection to labour market } \\
\text { participation of mothers with } \\
\text { children of } 6>\end{array}$ & 84 & 44 & 42 & 34 & 29 & 22 \\
$\begin{array}{l}\text { - Women are better suited to } \\
\text { raise children than men }\end{array}$ & & 77 & 66 & 54 & 44 & 38 \\
- $\begin{array}{l}\text { Child care should be a } \\
\text { shared responsibility }\end{array}$ & & & 84 & 76 & 88 \\
\hline
\end{tabular}

Source: SCP 1993 p.188

Because policies to improve women's labour market participation did not lead to equal positions, in 1994 the Netherlands Government sought advice of an Expert Committee on how to execute a redistribution of unpaid work between men and women in order to give women better opportunities in paid work. By Government order this Committee was to construct four redistribution scenarios for a future in which unpaid work would be equally divided between men and women. This redistribution should be completed in the year 2010 (Ministry of Social Affairs 1995). The Committee based its advice on an analysis of the four Intomart time use surveys, executed in 1975, 1980, 1985 and 1990, used earlier in this book. In the Committee's analysis households were divided into single people employed or non-employed; one- and two-earner couples and couples both non-working, with and without children; single people and couples of 65 and over; and children living with their parents. This analysis showed, not surprisingly, that unpaid work was most unevenly divided between one-earner partners and most evenly between two-earners with a wife working on the labour market for 30 hours or more. However, in two-earner households, in which the wife worked part-time, women also did the lion's share of unpaid work and even working single females had more hours of unpaid work than working single males.

\subsection{Policies for equal sharing of paid and unpaid work}

Equal sharing of unpaid work is impossible without equal sharing of paid work. To illustrate this point let us have a look at the distribution of unpaid work in one-earner families. Redistribution of unpaid work between partners in one-earner households is devoid of sense because the male half of the couple would have to do all paid work and half the unpaid work, so males would become overburdenend. It is self-evident that in this case women will do part of paid work. That is why policies aimed at dividing unpaid work more equally will also have to lead to a more equal division of paid work and vice versa. Therefore 
in section 9.7.1 to 9.7 .3 three sets of policies will be mentioned and analysed which lead to a more equal distribution of paid and unpaid work between sexes. They can mainly be found in social-democratic welfare states with a plateau-shaped labour market profile of women. No distinction is made between policies aimed at obtaining a more equal division of unpaid work and aimed at a more equal division of paid work, as they both lead to more equal positions of men and women in society. Because this book deals with economics, special attention will be paid to policies with financial incentives which have not yet been realized in the Netherlands and also to policies which have not yet been introduced, but are the subject of recent public and scientific discussion. Sections 9.7.1 to 9.7 .3 are at the same time an inventory and an evaluation of existing policies as well as of policies not yet introduced. The policies have been divided into three groups: family policies, income policies and labour market policies

\subsubsection{Family policies}

\section{- Maternity leave}

This is one of the most important provisions needed by working women. In all European countries a maternity leave is given varying between 14 weeks and 40 weeks. The benefits vary from 70 to $100 \%$ of the latest earned wages. In case of a very long leave part of it is unpaid (Pot 1992). In the Netherlands maternity leave is sixteen weeks with a $100 \%$ social insurance benefit. The maternity leave is flexible: women can start their leave 6 to 4 weeks before the supposed date of birth of the child and it ends 10 to 12 weeks after the actual date of birth of the child. The $100 \%$ benefit is continued for a maximum period of 52 weeks after the final day of the maternity leave, if the mother is ill as a consequence of the birth. Dutch law forbids employers to dismiss a pregnant woman or a woman who has given birth until 12 weeks after the date of birth. Self-employed women have to rely on private insurance.

\section{- Parental leave}

This is a leave to care for babies and young children. Parental leave differs from country to country. In Sweden for example both parents are given the opportunity for a paid leave. In that case they earn $70 \%$ of the latest salary during a 12 month period, which is followed by a 13 week period at a fixed rate. They are also entitled to a paid leave during 120 days in the event of sick children. Either of the parents is entitled to shortening working hours to 6 hours a day until the child is 8 years old, however without compensation (Gustafsson 1995). In other countries parental leaves vary from 10 weeks to 24 months.

In the Netherlands parental leave was introduced in 1991 when the Parental Leave Act took effect: both parents have the right to decrease their paid working week to twenty hours during six months. People in the civil service receive a $75 \%$ payment of the hours that they do not work. An evaluation shows that nearly $29 \%$ of all employees who are entitled to paid leave make use of it, whereas only $9.5 \%$ of all employees who are entitled to unpaid leave make use of it. 
In 1995 the European Employers' Organization (Unice) and the European Federation of Unions decided on a part-time leave of three months if employees become parents or if other family circumstances require it. The leave can be spread out over an eight year period. Employees cannot be dismissed during this leave and it is the intention of the agreement between Employers and Unions that employees keep their rights in social security (Trouw 7 November 1995).

Because parental leave is much in dsicussion in Europe and especially the question whether it ought to be a paid leave and who is to finance it, the Netherlands Central Planning Bureau (CPB) evaluated the effects of a simulation of a two months paid parental leave for breadwinners after the birth of a child. The CPB assumed that this leave does not diminish productivity, causes no loss in the use of capital goods and is paid for by a relative decrease of all wages. The effects are positive for production, employment and labour supply in persons, as they increase, as well as for unemployment, as it decreases. Consumption, however, also decreases (Ministry of Social Affairs 1995).

\section{- Calamity leave}

This is a short leave to care for sick family-members, neighbours or friends or in case of other calamities in the family. Calamity leave is in existence for instance in Sweden, Denmark, Germany and in Belgium for civil servants. Germany knows a parental leave in case of sick children for a maximum of 10 days a year per child (Dankmeyer et al. 1992). In Sweden parents are entitled to 120 days leave a year per child under the age of 12 (Dankmeyer et al. 1992; Pot 1991; Gustafsson 1995).

In the Netherlands some collective wage agreements entitle employees to take leave in case of calamities. Research among members of one of the leading Dutch unions shows that $89 \%$ of the respondents would like to have the possibility to take a 2 or 3 day leave for such calamities with a maximum of 6 to 10 days a year (Dankmeyer et al. 1992).

\section{- Child care}

Child care arrangements differ considerably from country to country. The one pole of child care arrangements can be found in the Nordic countries, where the Government arranges and subsidizes nearly everything, the other pole can be found in the USA, where child care is considered a market regulated arrangement. If we take Sweden as an example for the Nordic countries: subsidized child care is available for $48 \%$ of all children under seven and private child care for another $10 \%$. The quality is regulated by the Central Goverrment. Parents pay $10 \%$ of the costs, Municipal Government $43 \%$ and Central Government $47 \%$ (Gustafsson 1995). In the USA parents organize child care themselves. The Netherlands is in between: subsidized child care is available for only $5 \%$ of young children. Parents pay about one third of the costs, employers one fifth and Central Government pays the rest. A tripartite way of financing: parents, Municipal Government and employers each for one third is the target of a new policy. A minimal legal quality is garantueed for a period of 4 years 
Child care is in discussion in many countries and consequently much attention is paid to an evaluation of research in this field in the Netherlands. Child care is a vexed question with many aspects. Is it good or bad for a child's psychological and sociological formation? (Singer 1993). This is a question related to the quality of child care. Does child care improve women's economic independence? If this question is answered affirmatively, then another question is, whether the enlargement of the life income of mothers is big enough to compensate for the costs of child care. The answer to the last question depends on the amount of government subsidies. However, for the Government the question is whether the cost of subsidizing are compensated for by a higher tax revenue because life incomes of mothers are enlarged. Is Government regulated and subsidized child care a way to improve equity between men and women? Should subsidized child care be restricted to mothers (and fathers) who participate in the labour market for a minimum number of hours or is it a social provision to which all children of a certain age should be entitled like primary education? Should employers contribute for some of their female employees as is the custom in the Netherlands nowadays? The State Committee that formulated scenarios for an equal division of unpaid work in the year 2010 advised that child care should become a basic-provision and a Government responsibility in the same way as education, as formulated in Article 208 of the Dutch Constitution.

Some answers to the above-mentioned questions are available from research. Gielen (1993) simulates the effects of more subsidized child care with the model MIDGET (MIni model Designed to experiment on Growth and Economic Theory). This model has nearly the same characteristics as MIMIC. He assumes that extension of subsidized child care would lead to substitution of nonsubsidized child care, so the demand for child care on the non-subsidized market would diminish. For this reason the effect of more subsidized child care on labour market supply of women is small. He restricts his analysis to the effects of changes in the price of child care. Other factors such as the quality and availability of public child care are also important. Working mothers prefer public child care or paid care at home over other informal child care (Research voor Beleid as quoted in Ministry of Social Affairs 1995 p.35). They appreciate public care because of its continuity and reliability (Tijdens et al. 1994).

Maassen van den Brink and Groot (1995) simulate the effect of the use of child care and conclude that the use of child care increased female labour market participation. After deducting the cost of subsidized child care women's labour income was nearly twice as high as the labour income of non-users of child care (Maassen van den Brink and Groot, 1995). So in the Dutch situation women's economic independence improved by the use of subsidized child care. Groot and Maassen van den Brink (1992) regard Government subsidies in the form of a deduction on income tax a more efficient way of subsidizing because $30 \%$ of the women who make use of subsidized child care in the Netherlands do not participate in the labour market. 
The price of child care seems of importance: the higher the price the lower the labour market participation (Gustafsson and Stafford 1992; Ribar 1992; Blau and Robbins 1988 as quoted by Maassen van den Brink, Gustafsson and Groot 1995). A lower income and a higher price of child care lead to a lower use of child care (Hotz and Kilburn 1991; Ribar 1992; Groot, Maassen van den Brink and Oosterbeek 1991 as quoted by Maassen van den Brink, Gustaffson and Groot 1995). In the Netherlands the users of paid child care are better educated and have higher labour incomes than the users of unpaid child care (Maassen van den Brink and Groot 1995). The cosst of child care may influence labour market behaviour of mothers and hence their unpaid work.

Research in Sweden and the United States (Gustafsson and Stafford 1992; Blau and Robbins 1988; Ribar 1992; as mentioned in Maassen van den Brink et al 1995) showed that labour market participation of women is negatively influenced by high costs of child care. Use of child care by mothers not participating in the labour market is even more influenced by the costs of child care (Hotz and Kilburn 1991; Ribar 1992; as mentioned in Maassen van den Brink et al 1995). Groot, Maassen van den Brink and Oosterbeek (1991; 1992) also found a negative influence of high costs on the use of child care (quoted by Maassen van den Brink, Gustaffson and Groot 1995). However, research by Maassen van den Brink and Groot (1995) showed that the price of child care has no significant influence on labour market supply of mothers. As possible explanations the authors mentioned: 1. Income related prices do not reflect the relation between demand and supply of child care; 2 . As public child care is rationed demand exceeds supply.

Maassen van den Brink and Groot (1995) calculated that for the Government the costs of subsidizing child care are $23 \%$ higher than the extra tax revenues of one year of the women who make use of this subsidized child care. They did not calculate the extra tax revenues over the life time income of these women. For every year that a woman is out of the labour market her yearly income diminishes with 1.5 to $2 \%$ (see chapter 8.3 ) and so does the tax she has to pay. Earlier Groot and Maassen van den Brink (1992) concluded that if the Government subsidizes child care to improve women's economic positions it is efficient to restrict child care to mothers (and fathers) who participate in the labour market. If the policy is a recognition of children's rights as social subjects, all children should be entitled to child care. Maassen van den Brink and Groot point out that there is an exchange between equity and efficiency: entitlement to subsidized child care for all children of a certain age seems just from a social point of view, but restriction of subsidized child care to working mothers is efficient for the treasury, especially if employers contribute in the costs of child care. If a Government has limited means to subsidize child care an optimum is reached if the number of children who receive this care is as high as possible, whereas the price the parents have to pay is not as high as to restrict the use of child care (Maassen van den Brink and Groot 1995). 
If the cost of child care is considered a labour cost of the working mother which should be (partly) paid for by the employer, the advantage is that women's labour market participation is stimulated. The disadvantage is that child care is restricted to mothers and contributes to sex segregation on the labour market. Another disadvantage is that employers will pay only for employees they consider important, for example women with a high education. A third disadvantage is that it ties women to employers who are willing to pay for child care.

Conclusion: from the point of child care as a means to improve women's economic position, child care subsidized by tax facilities seems to be efficient and just.

\section{- Subsidized Home-care}

Subsidized Home-care is a social provision much discussed in the Netherlands because it is scarce and the Government is economizing on care subsidies. Waiting lists for home-care can be found in many municipalities. The question in the present debate on care is to what degree voluntary unpaid help can and may be expected. Government is of the opinion that subsidized help is a supplement to voluntary help whereas women's organizations think that voluntary help is a supplement to subsidized home-care. On the one hand demand for help increases as a consequence of the growing share of elderly people in the population. On the other hand one can expect that supply of voluntary help is diminishing as a consequence of the growing labour market participation of women. Prognoses show that the demand for help based on a demographic extrapolation of population data will increase with $1.5 \%$ a year in volume (Commissie Welschen 1994; De Boer et al.1994). Current Government policy is aimed at decreasing subsidies to one third of this percentage and at substituting paid home-care for sick, elderly and handicapped people by unpaid care.

\subsubsection{Income policies}

\section{- Tax policy concerning unpaid work}

In all industrialized countries income tax is levied on money income only. The value of unpaid goods and services is taxed as an exception to this rule, for instance if part of the wage consists of food and boarding. Because the value of unpaid household work is not taxed, families with the same level of economic well-being are not treated in the same way. From a welfare perspective it would appear reasonable to tax all kinds of income, because a tax-free household production leads to unequal treatment of people in essentially the same positions (Bonke 1992 p.284). Already in 1973 Due and Friedlaender (1973) argued that adjustments of the tax systems "must be along the lines of allowing deductions of expenses of having housework done, since that is a cost of earning income" (Due and Friedlaender 1973 p.255). In 1975 the OECD pointed out that exemption from. taxation of unpaid work "imposes a bias favoring unpaid work in the home 
compared with paid work in the labour force" (Darling 1975 p.91). In 1981 Leuthold formulated it like this: "The argument for taxing home production income rests in the principle of equal taxation of equals. A person who works outside the house and earns an income of X dollars should pay the same tax as someone who produced goods at home with a value of X dollars"' (Leuthold 1981 p.277).

The non-taxation of unpaid labour has an influence on the allocation of time, especially on the allocation of time of women with al low-earning capacity. Their household production is free of any tax. If man and wife maximize household utility, working on the labour market is efficient only in case the net hourly wage of the wife is higher than the value of her hourly home production. The allocation of time between home production and labour market is disturbed by the fact that home production is not taxed. In the time allocation comparison the hourly wage minus tax and social premiums must compete with the hourly value of home production which is not taxed at all. To my knowledge no research has been done on this subject.

\section{- Tax policy concerning paid work}

In many countries a tax relieve is given to the single breadwinner family: the single breadwinner has tax facilities for his "dependent" wife. Such a policy is a further disincentive for the second earner of a family to participate in the labour market. The more so if income tax is progressive and the family is the unit of taxation. The income of the second earner is put on top of that of the first earner and taxed according to his highest rate.

An alternative is to tax each person as an individual. The effects of this individualization have been investigated by several researchers. A 1990 OECD comparison of tax systems shows that separate taxation is an incentive to switch earnings form the husband to the wife. This comparions further shows that tax influences are causing cross-country differences in overall rates of female labour participation up to 20 percentage points (OECD 1990 p.166/167).

Comparative research of several tax systems has shown that individual taxation is an incentive for women to enter the labour market (Gustafsson and Ott 1987; Gustafsson and Bruyn-Hundt 1991). It was shown that the wife's gross share in family income turns into a larger net share under a system of individual taxation. Under a system of joint taxation or another system that favours the single earner, the wife's net share in family income is smaller than her gross share, as is shown in table 9.2. In this table a microeconomic analysis of the wife's share in family income is made, based on micro datasets for couples in West-Germany, Sweden and the Netherlands. The 1984 German tax system was a splitting system. In this splitting system the assessable incomes of man and wife were added up and divided by two. The basic tax allowance for a married couple was twice as high as the basic tax allowance for a single person. Tax was calculated on half of the taxable income and multiplied by two. The Swedish tax system has completely been individualized. The Dutch tax system has been individualized for labour 
income, but the single earner is entitled to the general tax deduction of his dependent partner, apart from his own general tax deduction. The wife's contribution to the net family income is interpreted as the net decrease in family income if she withdraws from the labour market. This measure, which varies from zero if the wife does not work on the labour market to one if the wife is the only wage earner, has been computed using three datasets and three tax systems.

Table 9.2 .

Wife's share in family income before and after tax under different tax systems

\begin{tabular}{|c|c|c|c|c|}
\hline \multirow[b]{2}{*}{ All couples: } & \multirow[t]{2}{*}{ Before tax } & \multicolumn{3}{|c|}{$\begin{array}{l}\text { After tax } \\
\text { Tax system }\end{array}$} \\
\hline & & German & Sweden & Netherlands \\
\hline Germany & .150 & .124 & .166 & .147 \\
\hline Sweden & .288 & .237 & 311 & .282 \\
\hline Netherlands & .119 & .102 & .135 & .116 \\
\hline
\end{tabular}

Source:Gustafsson and Bruyn-Hundt 1991

The German wife's gross share in family income of $15 \%$ is reduced to $12.4 \%$ under the German splitting system, is enlarged to $16.6 \%$ under the Swedish individualized system and reduced to $14.7 \%$ under the Dutch tax system. The Swedish and Dutch wife's share is also bigger under the Swedish tax system than under the German or Dutch tax system.

The Netherlands Central Planning Bureau (CPB) also investigated the abolition of a marriage relief. In the current Dutch tax system the income of the partner is subject to the tax and national social insurance premium rate from the first guilder onwards. Cancelling the transferability of allowances between partners has following consequences: labour income of wives below the basic allowance is no longer subject to tax and premium rate of the first tax bracket. It encourages wives to participate in the labour market, because the husband looses his marriage relief, as is the loss of income supposing the husband has a full-time job. Gelauff and Graafland (1994) of CPB presented six variants of the abolition of marriage relief. They presented three variants in which the legal minimum wages are raised in such a way that a breadwinner who earns these minimum wages with a non-participating partner is just compensated for his loss and three variants in which the minimum wages are not raised. In two variants the abolition of the breadwinner facilities is used for a reduction of the government's financial deficit, in two variants the first bracket in income tax is lowered and in two variants the family allowance is raised to compensate households for the loss of breadwinner facilities. In all six variants labour supply as well as private production are higher. In the variants with higher minimum legal wages unemployment rises because the higher labour supply is not fully absorbed. 
Moreover, the effects on net income are positive for working single people, elderly people and breadwinners with a disability benefit. In other variants net income decreases for nearly everyone (Gelauff and Graafland 1994 p.226).

I regret that no variant has been presented in which the effects of the abolition of the transferability are shown on their own in order to be able evaluate the net. effects and the net proceeds of this change in taxation. Such a variant would better show the disincentive aspects of taxation than variants in which the proceeds are used for other purposes. Dutch women's emancipation movement wants to remove the disincentives and to use the proceeds of this change in taxation to encourage labour market participation of women, for example by financing individualization of social security and/or by extending public child care.

Recent research is done by Bekkering (1995). She investigates the effect of the abolition of the transferability of the basic tax allowance to the sole breadwinner. Her argument for this investigation was that the marriage relief causes price distortions for females who wish to participate in the labour market. Their marginal net wage rate depends on their household situation, whereas an optimal allocation requires that marginal net wages only depend on productivity. Firstly she estimates the relation between labour supply and income in a so-called Markov-model in which four possible situations figure: persons can offer their labour supply full--time, part-time, people are disabled or have no labour supply. As expected males' reactions to changes in own income are small, females' reactions are high. With this model she simulates the effects of the abolition of the marriage relief with two variants: one in which the loss of the breadwinner facility is compensated for by a generic increase of the tax exemption level and one in which the children's allowance is increased. Her argument for these compensations is that it was "reasonable" that the large gains of the abolition of the marriage relief for government are to be used for some kind of compensation: "individualization is not meant to increase tax revenues" (Bekkering p.99). She finds that in the variant with a higher tax exemption level in the long run female labour supply increases with 13 percentage points. The demand side of the labour market is not included, so in her view these long-term effects are not reliable. Therefore the first year effects are presented in more detail: the number of households in which either both partners or none of the partners participate increases after individualization. The reason: if the one-earner situation is made less attractive two reactions are possible: either the household becomes a two-earner family or the breadwinner applies for a welfare benefit and both partners withdraw from the labour market. So the dichotomy between households is stronger after individualization. This is also the case in the variant with higher children's allowance. The effect on the dichotomy of households is stronger for generic compensation and for higher educated people.

Bekkering finds that individualization does not affect male labour supply. Her conclusion is: "Thus individualization of taxes is not the best policy to stimulate men to do more household work. The division of household work does become 
more equal, but only because women have less time for household work, not because men spend more time in the household" (Bekkering p.104). I do not entirely agree with this conclusion because it suggests that individualization does not contribute to a more equal distribution of unpaid work between men and women. This is not true as can be read from her own statement that "division of household work does become more equal".

My conclusion is that Bekkering's analysis shows that after individualization there are less one-earners and more (full-time) two-earners. This will make the division of unpaid work between men and women more equal. Another conclusion that can be drawn from Bekkering's data is that after individualization the number of partners both non-participating in the labour market has increased. Time use survey shows that men's share in unpaid work is higher if both partners do not participate in the labour market (Ministry of Social Affairs 1995 p.198/199).

Bekkering mentions (p.102) that the most "pure" form of tax individualization is the abolition of the marriage relief without any compensation. The reactions of females would be different if no compensation was given in the form of generic tax decrease or an increase in children's allowance. The increase in family income resulting from these compensations is a disincentive to female labour supply as Bekkering herself remarked on pages 102 and 110 . In my eyes it is inconsistent to investigate the effects of the abolition of marriage relief on income and at the same time increase income by giving compensations for the loss of the marriage relief. If "individualization is not meant to increase tax revenues" as Bekkering poses, the gains of the aboliton of the marriage relief could be used to facilitate the combination of paid and unpaid work. For example by creating a possibility to make costs of household services income tax deductable or by extending subsidized child care. It is a pity that models such as Bekkering's or MIMIC do not take into account unpaid work. Women are supposed to look after children and to run the household. They have to choose how to divide their time over paid work, unpaid work and leisure. If a woman accepts the possibility to substitute unpaid care by qualitative well-paid care and such a choice can be realized in practice, the marginal (after tax) revenue of an extra hour on the labour market should cover the extra cost of this hour inclusive of costs of child care. Because men do not consider child care costs, women react more strongly to financial incentives than men.

\section{- Tax policy concerning substitution of unpaid work by market goods}

The household has to make a choice between allocating time to the labour market or to home production, but it also has to choose between home production and buying goods and services on the market, provided such goods and services are available. Two factors are important: the availability of goods and services on the market and the price.

The availibility of goods and services has changed in the course of time. New products e.g. dishwashers, washing machines, tumble dryers, microwaves, TV- 
sets, audio-equipment increased people's preference for market-produced goods and reduced the relative value placed on nonmarket time (Blau and Ferber 1986 p.99-101). As is the case with buying meals in a restaurant, household help or child care, this decision is also influenced by taxation. Home production is cheaper than buying similar products on the market, because the costs of products and services on the market include Value Added Tax and social premiums. Buying on the market is more efficient only if the price on the market is lower than the "price" of home production, being the sum of value added plus cost of intermediate goods. There are two ways in which changes in taxation stimulate substitution of unpaidl work by goods or services bought on the market:

1. Deductibility of costs from income tax; for example the incentive for mothers to produce child care by staying at home, could be changed in an incentive to work on the labour market if the cost of child care could be deducted from taxable income as already pointed out by the OECD in 1975 (Darling 1975 p.92). Polachek (1993) argues that the unavailability of low-cost day care centers has the same effect on female labour market participation as high marginal tax rates (Polachek 1993 p.14). Instead of deductibility, the State Committee for Redistribution of Unpaid Work suggested a tax credit in income tax, for people who combine unpaid work with paid work (of at least 20 hours a week) because they have less time for household production (Ministry of Social Affairs 1995).

2. Lowering Value Added Tax on purchases of goods or services which substitute unpaid work such as dishwashers, ready-made products, window-cleaning services, house-cleaners or commercial laundries. Dutch Government gave a good example by fixing VAT on child care at $0.0 \%$ in 1995.

As far as I know no research is available on this subject.

\section{- Social security}

Social security systems were mainly determined in the first half of this century, when men were "breadwinners" and women "housewives". Policies based on this notion of sex differentiation regard the farnily as the basic administrative and economic unit. It was considered equitable to assign certain benefits to married men on the assumption that they are the sole or primary source of economic support for the family. Married women's claims on the social security system are still circumscribed in various ways on the grounds of assumed dependence on a husband.

At present social security systems are in a transitional phase: some policies are based on the notion of equal roles for men and women, whereas others tend to retard the process of social and economic change. Reforming the social security system is complicated by the fact that women have not yet achieved equality on the labour market and still bear a disproportionate high share of unpaid labour. Even if formal equality exists, meaning that there is no direct reference to sex, indirect inequality arises when disadvantages which women encounter on the labour market, are reflected in the social security system. The OECD remarks that 
this form of inequality is particularly pronounced in social security systems, which base entitlements on earnings and/or employment records. The OECD mentioned three causes for indirect inequality: 1. many women interrupt employment in order to care for young children; 2 . women are generally confined to low-earning occupations; 3 . women form a large segment of the part-time labour force (OECD 1985 p.140).

The OECD remarks that income-tested systems, with apparently neutral rules of entitlement, tend to put women at a particular disadvantage since many provisions are based on marital status (OECD 1985 p.140). Many schemes take the couple rather than the individual as income unit for means-testing. Given that the labour supply of married women is more elastic than that of men, joint means-testing might be expected to exercise a stronger work disincentive for wives than for husbands. Because in nearly all countries concerned there are more married women who have a husband with income, than there are husbands who have a wife with income, the percentage of working wives who receive a means-tested benefit is smaller than the percentage of husbands.

Most women work part-time and have a low hourly wage, so their labour income is lower, equal or only a little bit higher than means-tested family benefits. An individual unemployment benefit, independent of family income, would stimulate women more to (re)enter the labour market (Millar 1988; BruynHundt and Van der Linden 1989; Gelauff and Graafland 1992). Research by Millar in the United Kingdom (Millar 1988) and Kersten et al. in the Netherlands (Kersten et al. 1993) shows that the percentage of households in which both partners are unemployed rose because the effect of a family income means test discouraged partners to look for a job. Another disincentive is the insurance of housewives for cost of illness and in some countries a small state pension and/or the entitlement of the breadwinner to a supplement for his dependent spouse (Pieters and Schell 1990).

\section{- Abolition of breadwinner's supplementary benefits under the Supplementary Benefits Act (Toeslagenwet - TW)}

In the Netherlands breadwinners who receive benefits because of sickness, unemployment, disablement or old age, are entitled to supplementary benefits under the Supplementary Benefits Act (Toeslagenwet-TW). This supplementary benefit ensures that a one-earner couple will always have a minimum income of $100 \%$ of net legal minimum wages. Breadwinners of dependent partners born after 1 January 1972 do no longer receive this supplementary benefit, except when a child under 12 forms part of their household.

The State Committee for Redistribution of Unpaid Work advised the gradual abolition of these benefits and suggested the gradual introduction of social premiums for dependent partners in social security against the cost of sickness, state pension and child endowments. So far breadwinners do not pay extra premiums for dependent partners 


\section{- Abolition of the means test under the National Assistance Act (Algemene Bijstandswet - ABW)}

The Unemployment Benefits Act (Werkloosheidswet - WW) has a dual character. During the first phase of unemployment people receive an individual salary-related WW-benefit, independent of the income of other household members. The duration of this benefit depends on the number of years previously worked. After this period the unemployed person receives from the government a benefit under the National Assistance Act (ABW) which is meanstested and is reduced proportionally if other members of the household have an income. The ABW-benefit is $100 \%$ of legal minimum wages for couples, $90 \%$ for one-parent families and $70 \%$ for single people. The means test is very discouraging for labour market participation of female partners who work parttime, because they have to earn more than $100 \%$ of the legal minimum wages before net family income is raised. An individual ABW-benefit of $50 \%$ for each partner is a strong incentive for unemployed couples to look for a job. Gelauff and Graafiand (1994) simulate two extreme variants of individualization of ABW-benefit: one in which improper use can effectively be prohibited and one with a maximum of improper use. By improper use they mean that all. housewives and wives with small part-time jobs apply for a benefit and the authorities cannot check effectively if they really want a job or if not enough jobs are available. The effects of individualization are positive for private production, employment, tax rate and public expenditures if no improper use occurs, although the unemployment rate is raised. When improper use is at a maximum the effects for private production, employment, tax rate and public expenditures are disastrous, although the unemployment rate lowers (Gelauff and Graafland 1994 p.233). They conclude that although it is very hard to make a final probability judgment on improper use, macroeconornic results are unfavourably influenced, if more than one in eight partners collect AWB-benefits on improper grounds.

Two notes on this exercise:

- It is not realistic to suppose that in 1995 all hitherto unentitled women and even women with part-time jobs claim benefits. Nor is it realistic to suppose that the administration of social security has no means and no sanctions to check if these women really want to participate in the labour market. A precedent in 1984 is proof of this(19).

- It is not reasonable to individualize taxation by cancelling the transferability of the basic tax allowance and to argue at the same time that individualization of unemployment benefits is impossible. Moreover, even if maximum improper use is supposed, the public deficit increases only by $0.1 \%$ of NNP if unemployment benefits are individualized. This is less than the decrease in the public deficit of $2.0 \%$ of NNP as a result of the abolition of

19 Before 1984 married women were not entitled to an unemployment benefit under the WWV (Wet Werkloosheidvoorziening, - Unemployment Benefits Act). By virtue of the third Equal Treatment Directive of the European Community this law was changed in 1984 in favour of married women. The costs were estimated at 1 billion. Dutch Guilders. Because of an overestimation of the number of women claiming this benefit as well as an overestimation of the level of the benefit the definitive costs turned out to be 0.315 billion Dutch Guilders, or less than one third of the original estimation (Van 't Eind et al. 1986). 

233).

\section{- Pensions}

In a majority of EC-countries pension schemes are linked with employment and benefits are calculated on the basis of years of contribution. Such schemes are typical examples of provided primary benefits for insured workers, from which benefits for wives of workers are derived on the assumption that married women are unlikely to have worked sufficiently long to acquire independent entitlements. Rising female labour force participation rates have meant that an increasing proportion of women are gaining autonomous pension rights. At the same time, changing family patterns and new perceptions of women's role have created dissatisfaction with derived rights (OECD 1985 p.142).

In most industrialized countries widows of breadwinners receive a (small) widows' pension(20). Under earnings related insurance systems these usually take the form of a proportion of the deceased worker's pension (for example Germany and France). Under universal or income-tested arrangements (for example the Nordic countries, the Netherlands and Great-Britain) survivors are entitled to old age pensions in their own right (Pieters and Schell 1990).

The OECD remarked that derived rights raise two major problems:

A. Derived rights may entail gaps or inadequacies:

If the survivor's pension is linked with the breadwinner's employment period, the level of widow's pension is often so low, that there are high poverty rates among widows. In some countries pensions are payable to widows under a certain age only if they have dependent children. The qualifying age for widows without dependent children may be as high as fifty or fifty-five. So for women with little employment experience the gap between the time when the children cease to be dependent and the re-qualifying age for the pension may entail considerable hardship.

B. Derived rights may lead to inequities:

The continued provision of derived rights in countries with a high and rising labour market participation rate of women, leads to inequities. It may happen that the pension of an employed women is less than the derived pension of a widow. Another inequity is that the combined pensions of couples who worked part-time is less than the pension paid to one-earner couples with similar earnings (OECD 1985 p.146).

The inequities arising from the coexistence of individual and derived rights are likely to increase as more women enter the labour market. A solution for this problem would be a phasing out of derived rights as is done in Sweden.

The OECD remarks that "it may be viewed as an easier political exercise in the

20 In the Netherlands the widows' pension will be gradually abolished after 1 July 1996, unless the widow was born before 1950 or has children under 18 . The benefit is reduced if she has a labour income (Arachne 2.2.1996). 
short term to improve derived rights, or even to make them reciprocal" (OECD 1985 p.148).

To my knowledge France is the only country which entitles parents to a right on pension based on caring for children. A parent who has raised at least three children is entitled to a supplement on his basic pension if his spouse is dependent and he does not have other income (Pieters and Schell 1990 p.74). In other countries unpaid labour does not give a right to pension. So women, for whom unpaid work is their main or principal activity, are dependent on a breadwinner in old age (the same applies however to France, because he is only entitled to a supplement).

\subsubsection{Labour market policies}

In chapter 5.5 .3 and chapter 8.5 attention was paid to the different positions of men and women on the labour market. As has already been stated in chapter 5.5.3 the characteristics for the labour market position of people doing much unpaid labour (mostly women) are:

- they work only part of their adult life on the labour market and if they work on the labour market they work part-time, in temporary jobs or other forms of atypical employment (European Commission 1993 pp.34-44);

- their hourly wage is lower than the hourly wage of people doing the same job (EC 1993 Pp.45-51);

- they are concentrated in fewer professions and sectors of industry than people working full-time (EC 1993 Pp.13-23);

- in most countries they are more often and longer unemployed than people working full-time during their adult life (EC pp.24-33);

- they have less rights in social security and pensions than people working full-time during their adult life (EC p.32).

- consequently: people who spend a considerable part of their lifetime on unpaid labour have another position on the labour market than people who work full-time in the productive phase of their life. Their lifetime income is much smaller, because they work fewer years, fewer hours per year, earn less per hour, have fewer rights in social security and pensions (see for instance OECD 1988).

Strategies to improve women's labour market position are programmes to diminish the wage gap between men and women, to change the underrepresentation of women in technical and economic professions and in management positions, to pay special attention to women's choice of profession, to decrease their higher rate of unemployment, to entitle them to equal rights in social security and pension schemes. Although some of these policies have been in operation for years, they are still under discussion. 


\section{- Equal opportunities}

In 1919 the International Labour Organization stated that women should receive the same wages as men for the same work. In article 119 of the 1957 Treaty of Rome this principle has again been laid down. From 1974 on the European Commission has launched several social action programmes for equal rights and opportunities for women. International Women's year in 1975, the United Nations Decade for women, the International Women's Conferences in 1975, $1980,1985,1990$ and 1995 as well as Conventions of the International Labour Organization have been enormously important for the development of equal rights policies. In the seventies and eighties the European Commission elaborated the principle of equal treatment in five Directives. The directives on equal pay and equal treatment on the labour market (hiring and firing, on-the-job-training, promotion, secundary labour conditions, social security and pensions) have had a major impact and have resulted in new legislations or amendments to existing legislation in these fields in EC countries.

The question arises: what is equal treatment? Direct discrimination, being unequal treatment based on sex or a characteristic that refers to sex is forbidden. However, neutral legal formulations do not lead to equal material positions as women differ from men biologically, they give birth and bear the brunt of child care and household tasks. Indirect discrimination is unequal treatment based on other characteristics than sex, which nevertheless puts women at a disadvantage. If for example a minimum body length is required for a job, women are at a disadvantage. Indirect discrimination is only admitted by the International EC Court of Justice of the if there is an objective justification. Equal treatment under equal circumstances is right, but unequal circumstances demand unequal treatment. What circumstances should be taken into account if women are to have equal opportunities? Special rights, a preferential treatment, positive action are means to enhance actual equal conditions for women. This question has not been solved (Van Vleuten 1992).

Despite the 1976 Equal Wage Act the wage gap between men and women in the Netherlands still exists. Recent research in the Netherlands shows that women's wage is 74\% of men's (SZW-Nieuws 23 November 1995). In other EC-countries similar Acts came into being between 1975 (Belgium) and 1984 (United Kingdom) but women's wages are 63 to $81 \%$ of men's (EC 1993 p.47).

The EC developed several projects to improve women's labour market position. CEDEFOP is the European Center to advise the European Committe: on the development of professional training for women. Via the network Diversification experts in professional training for women are united to investigate why women choose traditional female professions and to enlarge their possibilities by giving information and positive action. Via the so-called IRIS-network member countries can participate in more than 200 projects, including conferences, exchange programmes, newsletters, to learn frum each other's experiments and experiences. NOW is a new community initiative to improve equal opportunities for women in employment and education by 
stimulating the establishment of small enterprises and cooperatives, by giving help in financing, child care and technical advice. The European Social Fund provides financial aid for projects which improve employment chances.

In several national media campaings the Dutch Government pointed out that women should choose an education in technology and participate in traditional male professions. Slogans like: "Choose something else-choose exact" ("Kies eens wat anders, kies exact"), "A clever girl anticipates her future" ("Een slimme meid is op haar toekomst voorbereid"), and "A real bloke irons his own shirt" ("Een echte vent strijkt zijn eigen overhemd") were used to break through traditional male/female roles in society. Subsidies were given to introduce women in the building and metal industries and projects were started to inform women on technical education and professions.

Although the concentration of women in female professions diminished between 1983 and 1989 in all EC-countries except France and Spain, sex segregation in occupation and jobs has not disappeared. Women are still concentrated in fewer professions than men (EC 1993 p.20/21).

\section{- Positive Action}

Postive Action (or Affirmative Action) is an instrument to improve women's position in labour organizations. It is a coherent programme of requlations inside labour organizations to attain a representative composition of women in personnel (De Jong 1992). Programmes can be set up on different levels and with different sanctions. Positive action is mostly concentrated on the firm, but can also be executed on the level of Central Government. The first example was given in 1941 when President Roosevelt forbade discrimination against black workers in contracts the US Government made with the war industry. Later presidents extended these contracts to other terrains. In 1967 legislation was introduced which forbade discrimination against women. Government suppliers were obliged to make positive action programmes and regulations in order to get a representative composition of their personnel (contract compliance) (De Jong 1992).

In Europe in the eighties and nineties programmes of the European Commission gave an important impuls to positive action programmes. In 1988 the European Commission approved a Code of Practice with directives for making and executing these programmes to improve women's position. The aim of a prograrnme can differ from child care to transport from home to work, from gathering data about the male/female ratio in personnel, to preference for women over men in selecting and hiring personnel. The programme should have quantitative targets, a time path, a packet of measures, a registration system and controll on the progress (De Jong 1992).

Central Government in the Netherlands have subsidized the hiring of special assistants for positive action and special activities since 1989. Municipalities and non-profit organizations request subsidies for a special assistant, business firms 
request it for special activities such as an analysis of the personnel file, a special training or a hiring campaign. The subsidies have had positive effects on the development of positive action although research shows that people do not like the term "positive action": it is associated with discrimination of men (Ministry of Social Affairs 1994). In 1994 positive action was introduced in management positions in education, because many women work in the educational system but few have management positions. In 1995 Government decided to continue the positive action subsidy to search for new instruments and entries in business. In Britain and the Netherlands a campaign "Opportunity 2000" has started or is about to start, which aims at improving labour market participation of women, quantitatively as well as qualitatively (Ministry of Social Affairs 1995).

Positive action has become contested. A verdict of the International EC Court of Justice by the end of 1995 in the case Kalanke versus Bremen brought much uncertainty concerning preferential treatment of women in hiring (Op Gelijke Voet 1996). Yet Governments in the European Union continue to promote positive action.

\section{- Comparable worth}

Comparable worth (or pay equity) is a strategy to improve labour conditions for women on the occupational level. This strategy relies on the use of objective criteria to value the content and requirements of jobs. Systems to evaluate jobs often turn out to be gender biased (Michael et al. 1989; Van Doorne-Huiskes 1992). Job evaluation systems do not evaluate jobs in an objective scientific way, they measure what is found just in a certain culture (Van Doorne-Huiskes 1992). Michael and Hartmann (1989) think that if differences in wages or other labour conditions are attributed to legitimate market forces there is no social ill and hence no rationale for any medecine. Comparable worth strategy comes in the picture if:

1. there is a gender difference in wages which is not explained by legitimate market forces.

2. the gender difference is linked to the undervaluation of jobs held disproportionally by women

3. the jobs can be objectively evaluated (Michael and Hartmann 1989). Research shows that the percentage of women in an occupation has a significant effect on the wage: $10 \%$ more women account for a 2 to $2.6 \%$ lower wage (Sorensen 1989; Baron and Newman 1989).

Job classification-systems are systems to evaluate the weight of different functions inside a labour organization. Evaluation can take place by giving points or by compairing different characteristics. The EC-Directive $75 / 117$ prescribes an equal wage for work of comparable worth. As most jobs are done either by men or by women it is difficult to establish what work of comparable worth is. The job evaluation is arranged in such a way that the attached weights are in conformity with the practice inside the labour organization. In other words: a job evaluation system is not an objective scientific instrument. Therefore job evaluation is a vicious circle: if structural inequality exists between the renumeration of male 
and female work, job evaluation will not change this inequality. It turns out that skills needed for female professions are valued lower than skills needed for male professions. The Hay System which is used in Canada tries to establish a gender neutral evaluation (Van Doorne-Huiskes 1992).

\section{- Direct measures to improve women's labour market positions}

As Dutch women's unemployment rate is higher than men's, the special Offices responsible for finding jobs for the unemployed have an assignment to make women's share in mediating the same as their share in unemployment. An initiative of trade union women in the eighties to start special schools in which women returning to the labour market were trained for professions with good employment opportunities and for jobs suitable for women, was very successful. Another successful initiative was the start of centers where women returning to the labour market could get information and advice on job opportunities and where short informative courses were given about the functioning of the labour market. Unfortunately subsidies for both initiatives have been diminished and the activities have been integrated in the Labour Offices (Arachne 15.2.1996).

Dutch women are leaders in part-time jobs: $62 \%$ of all working women work part-time against $8 \%$ of all working men (Ministry of Social Affairs 1994). In the nineties the Minimum Wage Act and social security regulations were changed in a way that part-time workers are also entitled to a minimum wage and social security benefits. By the end of 1995 draft legislation was drawn up prescribing that part-time workers should receive equal treatment in other aspects like promotion, on-the-job training, quality of work and workers' right of say (Arachne 2 February.1996).

About one third of working female employees experiences hindrance due to some form of sexual harassment or, as it is called in Dutch Law: sexual intimidation. The Government launched media campaigns about this phenemenon and since 1994 all employers have become obliged under the Labour Conditions Act (Arbeidsomstandighedenwet) to develop a policy to prevent sexual intimidation (Ministry of Social Affairs 1994).

Recent proposals by the State Committee who made scenarios for an equal distribution of unpaid work between men and women are:

- A packet of measures to make the length of the paid working week more flexible and promote fully-fledged part-time jobs

(Ministry of Social Affairs 1995).

- A legal right to work part-time should allow more men to fulfil their wish to have a shorter working week. Research shows that only $15 \%$ of all Dutch couples consider the one-earner situation ideal, yet $41 \%$ of all couples are living in this situation because men find it difficult to work part-time.

- Negotiations between employers and trade unions should lead to the right of fully-fledged part-time jobs for all employees, stated in collective wage agreements. Fully-fledged part-time jobs are defined as jobs with equal 
career prospects as full time jobs and an income which ensures financial independence. The traditional one-earner family is making place for the two-earner family, where both partners have to combine unpaid and paid work. Hence a "new employee" is coming up who does not want to work full-time the year round during 40 years.

- Employees who decide to change their full-time job into a part-time one maintain their old rights in social security (unemployment, sickness and disablement benefits) during a one year period.

- Employers receive subsidies for their contribution in social security for any form of shortening the working week.

- Elexible working hours enable parents to take care of their children and home in turns. In the new Dutch Act on Working and Resting Hours (Arbeidstijdenwet) the fact that employees should be able to combine labour and care has been formulated as a target.

\subsection{Summary and conclusion}

Unpaid work contributes much to general and individual welfare but its unequal distribution between men and women is a pitfall for women to obtain economic independence by doing paid work. Neither wages for housework nor a basic income provide a structural solution for this problem. Comparing different welfare states it turns out that the Nordic countries have succeeded best in improving women's position by stimulating policies which make it possible to combine paid and unpaid work. In the Netherlands Government policies before 1990 stimulated women's labour market participation, but the unequal distribution of unpaid work did not get much attention. This only changed after 1990. In 1995 a State Committee published scenarios for an equal distribution of unpaid work in the year 2010. In the last section of this chapter three groups of policies which stimulate a more equal distribution of paid as well as of unpaid work are described and analysed. 



\section{SUMMARY}

People in developed countries spend over $40 \%$ of all time available in their lives on personal care (eating, sleeping, personal hygiene etc.), 25 to $30 \%$ on leisure (watching TV, sports etc.) and 25 to $30 \%$ on labour. When talking about labour most people automatically think of "paid" labour. This is remarkable as the total of unpaid hours of work is 1 to 1.5 times higher than the total of paid hours of work. In all countries women's share in unpaid work is considerably higher than that of men.

The central question of this study is the economic value of unpaid work. A second question discusses the consequences if this value is taken into account at determining economic phenomena such as production and consumption, economic growth, employment and unemployment, personal income distribution etc. These questions are dealt with in Part 1.

Part II discusses the question of the influence of the unequal division of unpaid work between men and women on the their economic independence and consequently on their positions in society. Is it impossible to change economic independence without changing the unequal division of unpaid work.

In chapter 2 the growing attention of economic science for unpaid labour is discussed. The American economists Mincer, Becker and Gronau made it clear that family households are households of productions as well as of consumption. Unpaid work consumes the scarce time individuals have available, which could also be used for other purposes. Although unpaid work does not pass a market, its value could be estimated by considering a market substitute. Any human activity which could be performed by a third person could be referred to as unpaid work. In this respect not only the value of unpaid work done by people who also do paid work is of importance, but also the value of unpaid work of people who are outside the paid labour market because they are too young, too old, unemployed or handicapped. After all by doing unpaid work these people yield savings, which have value.

Chapter 3 deals with different methods to determine the value of unpaid work. The input method takes the total of unpaid hours as a starting point and multiplies it by a price per hour. This price per hour may be a price which is paid on the labour market for a worker who can replace the unpaid worker. This price per hour may be gross or nett or gross inclusive of employer's contribution in social security. Another approach is to take the wages that the unpaid worker loses by not working on the labour market, the so-called "opportunity costs".

The "output method" takes as a starting point the value that goods and services produced with unpaid work would have on the market. In economic literature macro estimations of the value of unpaid work differ from 6 to $72 \%$ of the Gross National Product, depending on the method adopted, the number of people and 
the ages of the people who are considered to do unpaid work, the activities which are counted as unpaid work and the price which is used for the estimations. As time use studies are available, contrary to data for the output method, I chose the input method. Gross market wages plus employer's contribution in social security of a general substitute were chosen as price component because they are also used in the National Accounts.

In chapter 4 the calculation of the value of unpaid work in the Netherlands is based on the "input method", the hours of time input as time studies of 1975, 1980,1985 and 1990 indicate. These time use studies can be compared with each other because the same questionnary and method have always been used. Unpaid hours of the entire Dutch population of 12 years and over are multiplied by three different gross hourly wages inclusive of employer's contribution in social security, being the legal minimum (hourly) wages, the wage of a home help in wage scale 12 and the average earned wages in the relevant year. The outcome of these calculations is a value for the entire population of 12 years and over, which varies from 51 to $110 \%$ of GNP, depending on the estimated wages. In case only the value of unpaid work of the population in the age of 25 to $64 \mathrm{k}$ is taken into consideration, the value of unpaid work is 36 to $78 \%$ of GNP, depending on the estimated wages. The percentages are higher than those of estimations in other countries. This was due to the fact that during the period considered the labour market participation of Dutch women was lower than elsewhere and in this study gross wages inclusive of employer's contribution to social security was used instead of nett wages. The share of unpaid work in all work increased until 1985 , but in 1990 it was lower than in 1975. The number of hours of unpaid work done by men increased, that of women remained more or less the same. The total workload of paid and unpaid work in all age groups was higher for women than for men. In the years 1985 and 1990 the age group 35 to 49 was an exception to this picture. The work load of elderly women was considerably higher than that of elderly men. In the research period the number of working hours of women increased, whereas that of men decreased. Household work takes most hours of unpaid work.

Since the development of National Accounts in the nineteen twenties, economists and statisticians have discussed the question whether unpaid work should be incorporated in National Accounts. The arguments in favour and against are dealt with in chapter 5. Moreover it is indicated in which way unpaid work could be incorporated in National Accounts. My conclusion is that the difficulties of implementation of unpaid work in National Accounts could be overcome by presenting old and new accounts during a transition period. The presentation of the value of unpaid work in an Addendum or Satellite Account I see as a first step towards implementing the value of unpaid work. If the value of unpaid work would be incorporated in National Accounts, all kinds of economic variables would change. If unpaid work would be incorporated in economic statistics, the economic growth per head of the population would have been lower in seven of the nine calculations for the period 1975 to 1990. Cyclical fluctuations would be less substantial, the working population would be $45 \%$ 
higher, unemployment would also be higher, whereas in 1990 total consumption and investments would have been $75 \%$ and savings would have been $60 \%$ higher. Optimal Pareto allocation would get a different contents.

In most cases the personal distirbution of income is used as an indicator for individual welfare, taking into account the differences in size and composition of households. The change to which the personal division of income is submitted if the value of unpaid labour is taken into account, is the subject of chapter 6 . The income of one-earners and single parents turn out to become twice as high. The income inequality between different types of households decreases by 56 to $62 \%$ if the value of unpaid work is being counted.

In macroeconomic models unpaid work is not incorporated as a variable. In chapter 7 this is considered a deficiency. The few models in economic literature that do take unpaid work into account are discussed. In the Netherlands Plantenga and Sloep were the first who indicated that unpaid labour should be taken into account when creating models of the labour supply, as the organization of paid and unpaid labour are closely connected. Eventually suggestions are being made to take unpaid labour into account in macroeconomic models not only when modelling labour supply but also when modelling production, consumption, investments and savings.

In chapter 8 economic independence is defined as financial independence plus care independence. Financial independence is a bigger problem than care independence, because money income enables to buy goods and services which guarantee care independence. Also because insufficient data are available on care independence, this chapter mainly deals with financial independence. Although there are noticeable changes, still far more women than men do not have (labour) incomes. If they do have a (labour) income, there are more women than men for whom this income is below the social minimum. The lesser degree of financial independence is also shown by the limited number of women who earn half the family income and the small percentage that women represent in the total labour income.

Chapter 9 discusses the way in which economic independence of women can be improved. A wage for the housewife and a basic income do not turn out to lead to equal economic positions of women and men. It is not the unpaid work itself, but its unequal division between men and women, which is the pitfall for economic independence of women. The same applies for paid work. Chapter 9 is concluded by discussing three packages of measures, which are intended to divide paid work more equally between men and women: family policy, income policy and labour market policy. 



\section{BIBLIOGRAPHY}

Adler,H. and Hawrylyshyn,O.:"Estimates of the value of household work; Canada 1961 and 1971" in Review of Income and Wealth series 24, 1978, p. 333-355

Alchion, A.A. and Demsetz, H.: "Production, Information Costs, and Economic organization" in American Economic Review 1972 pp. $777-795$

Allen,S. and Wolkowitz,C.: The control of women's labour: the case of Homeworking" in Eeminist Review Februari 1986

Aslaksen,J. and Koren,C:."A women's perspective on income distribution: reconsidering the value of household work", paper to the Conference "out of the Margin" Amsterdam 1993

Arachne:"Feiten en cijfers", Adviesbureau Overheidsbeleid, Den Haag, 19.12.1994

Backhaus, J.G.: "De financiering van de welvaartstaat" (Financing the Welfare State). Rede bij de aanvaarding van het ambt van gewoon hoogleraar Economie van het Overheidsgedrag en de Publieke Sector aan de Rijksuniversiteit Limburg, 10 november 1989

Bakker,I.:"Gender relations, macroeconomics and structural change in the OECD in the 1980s" Paper for the Conference "Out of the Margin" Amsterdam 1993

Barker,D.K.:"Parete optimality, gender and the law", paper prepared for the International Conference "Out of the Margin" the Netherlands 1993

Baron,J.N. and Newman,A.E.:"Pay the man: effects of a demographic composition on prescribed wage rates in the California Civil Service" in "Pay Equity", eds. R.T.Michael, H.I.Hartmann and B.O'Farrell, National Academy Press, Washington D.C. 1989

Becker,G.S.:"A theory of the allocation of time", The Economic Joumal sept. 1965

Becker,G.S.:"Is economic theory with it? On the relevance of the new economics of the family" in Papers and Proceedings of the American Economic Association, May 1974

Becker,G.:"A treatise on the family", Harvard University Press, Cambridge Mass. 1981

Begeer,W. and Van Tuinen, H.K.:"Statistische operationalisering van het begrip informele economie" in "Preadviezen van de Vereniging voor de Stathuishoudkunde 1984", Stenfert Kroese, Leiden 1984 p.37-58

Bekkering,J.M.:"A microsimulation model to analyze income tax individualization", Tilburg University Press 1995

Bergmann, B.:"The economic emergence of women" New York 1986

Berkman,J. and den Dulk,C.J.:"Ontwikkeling van de inkomens-statistiek" (Development of income statistics) in "Denken en meten", Centraal Bureau voor de Statistiek,Den Haag 1978, p.54-67

Beneria,L.:"Reproduction, production and the sexual division oflabour" in Cambridge Journal of Economics 1979, 3, p.203-225

Beneria,L.:"Toward a greater integration of gender in economic" in World Development, December 1995

Bielby,W.T. and Baron,J.N.:"A woman's place is with other women: sex segregation within organizations" in "Sex segregation in the workplace", ed. B.F.Reskin, National Academy Press, Washington D.C. 1984

Blades, D.W.:"Non-monetary (subsistence) activities in the national accounts of developing countries" OECD, Paris 1975 p.53

Blau,F. and Ferber,M.:"The economics of women. men and work" Prentice-Hall, New Yersey 1986

Blaug,M.:"Economic theory in retrospect" Cambridge University Press, Cambridge 1978

Blundell,R. and Walker,I.:"Modelling the joint determination of household labour supplies and commodity demands" in The Economic Joumal June 1982 p.351-365

Bochove,C.A,van and Tuinen,H.K.van:"Revision of the system of National Accounts: the case for flexibility", Occasional Paper of the Netherlands Central Bureau of Statistics NA-006, 1985

Boer,A.H.de, Hessing-Wagner, J.C.,Mootz,M and Schoemakers- Salkinoja I.S.:"Informele zorg" (Informal Care), Sociaal en Cultureel Planbureau, Rijswijk 1994

Bonke,J.:"Distribution of economic resources: implications of including household production" in Review of Income and Wealth september 1992 pp. 281-293

Boserup,E.:"Woman's role in economic development", George Allen and Unwin Ltd, London 1971 
Böttcher,C.J.F.:"De werkeliikheid van het model" (The reality of the model), Stichting voor Publiekvoorlichting over Wetenschap en Techniek, Utrecht 1988

Brathaug, A.L.:"Value added in households", Paper for the meeting of national accounts experts, OECD, Paris 1991

Broekman,F:"Economic theories of leisure: some comments and suggestions." in De Economist 1978, nr.2, p.165-197

Broekman,F.:"Beschikbare en benodigde vrije tijd"' (Available and needed leisure), Stenfert Kroese 1980

Bruegel,I:" Gender relations and the rational household". Paper for the Conference "Out of the margin" Amsterdam 1993

Bruyn-Hundt,M.:"De huisvrouw als producente" (The housewife as a producer) in EconomischStatistische Berichten (ESB) 13.5.1970 - "De consument als producent" (The consumer as a producer) ESB 17.6.1970.

Bruyn-Hundt,M.:"Een geëmancipeerde inkomensvorming en -verdeling" (Ant emancipated income formation and distribution) in ESB 18.7.1973

Bruyn-Hundt,M.: "De West-Europese (gezins)huishouding als produktiehuishouding" (The West-European consumer household. as a producer) in "Huishoudkunde in Nederland" Miscellaneous Paper 161978 Landbouwhogeschool Wageningen, Veenman en Zonen, Wageningen

Bruyn-Hundt,M.:"Onbetaald werk in het nationaal inkomen" (Unpaid work in national income) in Intermediair 31.3.1978

Bruyn-Hundt,M: "Huisindustrie" (House industry) ESB 3.6.1981

Bruyn-Hundt,M.:"De waarde van onzichtbare arbeid gemeten" (The measurement of the value of invisible work) ESB 27.7.1983

Bruyn-Hundt,M." Verschuivingen in de verhouding tussen betaalde en onbetaalde arbeid" (Shifts in the ratio of paid and unpaid work) samen met Prof.Dr.W.Driehuis, Drs.Y.M.Koot en Drs.L. Mossel; Stichting voor Economisch Onderzoek der Universiteit van Amsterdam in opdracht van het Ministerie van C.R.M.juni. 1983

Bruyn-Hundt,M.: "Huishouden is onbetaalde arbeid maar huisvrouwenloon_geen oplossing" (Household work is unpaid labour, but a wage for the housewive is no solution), Van Loghum Slaterus, $1985,146 \mathrm{p}$.

Bruyn-Hundi,M. and Van der Linden, Th.: "De invloed van financiële prikkels op het arbeidsaanbod van vrcuwen" (The influence of financial incentives on women's labour supply), OSA-Werkdocument W 65, Den Haag 1989

Bruyn-Hundt,M.: "Van kostwinnersvoorzieningen naar economische zelfstandigheid: drie modellen" (From breadwinner facilities to economic independence: three models) in Sociaal Maandblad Arbeid november 1990

Bryant,K.W. and Zick,C.D.:"Incorne distribution implications of rural household production" in American loumal of Agricultural Economics, december 1985 pp.1100-1104

Bücher,K.:"Die Frauenfrage in Mittelalter", Leipzig 1909

Butter,F.A.G.den:"Macro-ecnomische modelbouw in discussie $I^{\prime \prime}$ in Economisch Statistische Berichten 9.11.1983 p.1045-1048

Çagatay, N., Eison,D. and Grown,C.:"Introduction to gender, adjustment and macroeconomics" in World Development December 1995

Chadeau,A. and Fouquet,A.:"Peut-on mesurer le travail domestique?" in Economie et Statistique, no. 136, september 1981, INSEE, Paris

Chadeau,A.: "Measuring household activities: some international comparisons" in Review of Income and Wealth 1985 p. 237-253

Chadeau, A and Roy,C.:"Relating households' final consumption to household activities: substitutability or complementarity between market and non-market production" in Review of Income and Wealth no.4 december 1986 pp. $387-407$

Chadeau, A :"What is households' non-market production worth?" in OECD Economic Studies no.18/1992 pp. $85-105$

Clark,C.:"The economics of house-work" in Bulletin of the Oxford Institute of Statistics, May 10, 1958 
Commission Welschen (Commissie Modernisering Ouderenzorg): "Ouderenzorg met toekomst". (A future for care for the elderly), Ministry of Volkshuisvesting, Welzijn en Sport, Rijswijk 1994

Compaijen,B. and R.H.van Til: "De Nederlandse economie": De Nationale Rekeningen" (The Dutch economy: National Accounts) Wolters Noordhoff, Groningen 1988

Compaijen,B. and den Butter,F.A.G.:"De publikaties van het Centraal Planbureau" (The publications of the Central Planning Bureau), Wolters Noordhoff, Groningen 1992

Costa,M.della:"Die Macht der Frauen und der. Umsturz der Gesellschaft" Merve-verlag 1972

Council of Europe:"Erom work in the family and home to an eccupational activity". Study Group II of the 1992/93 Programme of Co-ordinated Research in the Social Field, Strasbourg 1994

Dankmeyer,B., Bruyn-Hundt,M. and Tijdens,K."Calamiteitenverlof en verpleegverlof (Leave for calamities and care), AbvaKabo, Amsterdam/Zoetermeer 1992

Danziger,S, and Taussig,M.k. "The income unit and the anatomy of income distribution" in Review of Income and Wealth 1979,25 pp. $365-375$

Darling, M.: The role of women in the economy" OECD, Paris 1975

Deserpa,A.C.:"A theory of the economics of time" in The economic joumal 81(1971) pp.828-846

Devereux,J. and Locay,L:"Specialization, household production and the measurement of economic growth" in American Economic Review, May 1992 pp. 399-403

Doorne van-Huiskes, J:" De comparable worth-strategie" (The comparable worth strategy) in "Vrouwen en arbeidsmarktposities binnen de Europese Gemeenschap", deel 3, Open Universiteit, Heerlen 1992

Droogleever Fortuijn,J.:"Een druk bestaan: tijdsbesteding en ruimtegebruik van tweeverdieners met kinderen". (Use of time and space of two earner couples with children), Sociaal Wetenschappelijke Studies, Amsterdam 1993

Due,J.F. and Friedlaender,A.F.:"Government Finance: Economics of the Public Sector", Irwin, Illinois 1973

Eck,R.van:"Secondary activities and the National Accounts", Occasional Paper of the Netherlands Central Bureau of Statistics NA-003 z.j.

Ehrenfest,G.en Pen.J.:"De Ooievaarsregeling" (Benefits of the Stork) in Hollands Maandblad, September 1972 , pp.13-18

Ehrenfest,G.:"Een volksverzekering voor wiet het kind verzorgt" (A social security benefit for the person who takes care of the child), Katemen 2000 jaargang $1979 \mathrm{nr} .5$

Eind,G.J.van 't, Reijden,P.van der, Wiggers,G.:"Berekeningen op een bierviltje!" in Sociaal Maandblad Arbeid, Oktober 1986 pp.643-649

Einerhand,M.G.K.,Elshout,S.van den,Hoogteijling, E.M.J.:"De omvang van de werkloosheid in 1985 nader bezien" (The extent of unemployment in 1985 in retrospect) in Supplement bij de SociaalEconomische Maandstatistiek, Centraal Bureau voor de Statistiek 1986 no.6.

Emancipatieraad:"Emancipatiebeleid in macro-economisch perspectief" (Emancipation policy in macro-economic perspective) Den Haag 1989

Eisner,R.:"Total incomes in the United States 1959 and 1969" in Review of Income and Wealth March 1978 pp.41-70

Eisner,R.,Simons,E.R.,Pieper,P.J. and Bender,S.:"Total incomes in the United States 1946-1976 in Review of Income and Wealth 1982 p. 133-173

Eisner,R.:"Extended accounts for national income and product" in Lournal of Economic Literature december 1988 p.1611-1684

Eggink,E.,van Praag,B.M.S. and Hop,J.P.:"Een nieuwe kijk op de arbeidsparticipatie van vrouwen" (A new light on women's labour market participation) in Economisch Statistische Berichten 1.8 .1990 p.704-707

Elson,D.: "Gender awareness in modeling structural adjustment" in World Development December 1995

Ertürk,K. and Çagatay,N.:"Macroeconomic consequences of cyclical and secular changes in feminization: an experiment at gendered macromodeling" in World Development", December 1995

Esping-Andersen,G.:"The three worlds of welfare capitalism" Polity Press, Oxford 1990 
European Community, European Parliament:" Resolution about the estimation of the value of unpaid work by women" PE 148.132/rev. Brussels 1992

European Community, Commission of:"De positie van de vrouwen op de arbeidsmarkt" (The position of women in the labour market) in themanummer bij "Vrouwen van Europa" nr. 36, 1993

Evans,A.W.L:"On the theory of the valuation and allocation of time" in Scottish Joumal of Political Economy Vol.XXVI,February 1972 p.1-17

Ferber,M.A. and Birnbaum, B.G." The "New Home Economics:" Retrospects and Prospects" in Journal of Consumer Research Vol.4 June 1977 pp 19-28

Ferber,M.A. and Greene,C.A.:"Housework vs. marketwork: some evidence how the decision is made" in Review of Income and Wealth june 1983 p.147-159

Ferber,M.A. and Nelson,J.A." Beyond economic man" University of Chicago Press 1993

Fitzgerald,J. and Wicks,j::"Measuring the value of household output: a comparison of direct and indirect approaches" in Review of Income and Wealth. June 1990 pp.129-141

Flood,L. and Klevmarken,N.A.:"Market work, household work and leisure: an analysis of time-use in Sweden", Paper for the 22nd General Conference of the International Association for Research in Income and Wealth 1992

Floro,M.S.:"Economic restructuring, gender and the allocation of time" in "World Development" December 1995 pp. 1913- 1968

FNV:"Economische zelfstandigheid en solidariteit" (Economic independence and solidarity); Resolution Federatie Nederlandse Vakbeweging Amsterdam 1990

Freeman, R.B.:"Demand for education" in Handbook of Labor Economics Eds.:O.C.Ashenfelter and R.Layard, North-Holland, Amsterdam 1986

Galbraith, J.K::"The economics of the American housewife" in "Atlantic Monthly August 1973

Geest,L.van der:"Een tijdbom onder de econometrie" in Economisch Statistische berichten 24 en 31.8 .83

Geest,L.van der:"Freia en Kompas" in Economisch Statistische Berichten 18.1.84 pp. 53-61

Gelauff,G.M.M. and Graafland,J.J.:"Individualisering in sociale zekerheid en belastingen" in Economisch Statistische Berichten 77e jaargang, 14/10/1992 pp 1001-1005

Gelauff,G.M.M. and Graafland,J.J.:"Moclelling welfare state reform". Elsevier Science B.V., Amsterdam 1994

Geleijnse,L., Vrooman,J.C. and Muffels,R.J.A.:"Tussen ministelsel en participatiemodel: een verkernerde studie naar stelsel-varianten in de sociale zekerheid" (Between minisystem and participation model: a survey of sociale security systems), Sociaal en Cultureel Planbureau, Rijswį̣k, 1993

Gershuny,J.1.:"The myth of the service economy" in Futures, April 1977, p.103-114

Gershuny.J. and Robinson,J.P.:"Historical changes in the household division of labor" in Demography. Vol.25,no.4 November 1988 p. 537-552

Gielen, A.:"Womea. children and the labour market" doctoral thesis 1993

Goldschmidt-Clermont, L.: "Unpaid work in the household" International Labour Organization, Geneva, 1982

Goldschmidt-Clermont,L:"Output related evaluations of inpaid household work: a challenge for time use studies" in Home Economics Research Joumal December 1983, vol.12.

Goldschmidt-Clermont,L. "Economic measurement of non-market household activities" in InterrationaLLabour Review, 3/1990, pp.279 f.

Goldschmidt-Clermont, L:"Monetary valuation of non-market productive time-Methodological considerations" in Review of Income and Wealth. December 1993 pp.419-433

Graafland,J.J. and Zalm,G.:"De voetsporen van Tinbergen in het CPB" (Tinbergen's tracks in the Central Planning Bureau) in Economisch Statistische berichten 29.6.94 p.609-611

Graafland,J.J.: "Wisselwerking tussen formele en informele economie" (Interaction between formal and informal economy) Occasional Paper no.42 Netherlands Central Planning Bureau, Den Haag 1987

Grift,Y.K., J.J.Siegers,G.N.C.Suy:"Tijdbesteding in Nederland" (Time use in the Netherlands) Swoka, Den Haag 1989

Gronau,R::"Leisure, home production and work", "Lumal of Political Economy, 1977 vol. 85 nr.6. 
Gronau,R: "Home production-a survey" in "Handbook of labor economics" eds. O.C.Ashenfelter and R.Layard, North-Holland Amsterdam 1986 chapter 4

Groot,L.F.Schippers J.J. en Siegers J.J.: The effect of interruptions and parttime work on women's wage rate: a test of the variable intensity model" in De Economist nr. 31988

Groot,W. and Maassen van den Brink,H.:"Arbeidsmarktparticipatie en kinderopvang" (Labour market participation and childcare) in Economisch-Statistische Berichten nr.3870, 1992, pp. 731-734

Grotenhuis, S.:"Loon voor huishoudelijke arbeid?" (A wage for household work) in SocialistiesEeministische Teksten no.4. Sara, Amsterdam 1980

Gustafsson,S.:"Equal opportunity policies in Sweden" in "Sex discrimination and equal opportunity: the labour market and employment policy" eds. G.Schmid and R. Wentzel, Gower Publishing Cy London 1984

Gustafsson,S. and Ott,N.:"Demegraphic changes labor force participation of married women and the effect of separate versus joint taxation of eamings in West Germany and Sweden" Arbeitspapier nr. 241,Sonderfurschungsbereich 3, J.W. Goethe Universitat, Mannheim 1987

Gustafsson,S. and M.Bruyn-Hundt:"Incentives for women to work: A comparison between the Netherlands, Sweden and West Germany" in \oumal of Economic Studies , Volume 18 number 5/6 1991 p. $30-66$

Gustafsson,S.S.:"Kinderopvang in een internationaal perspectief" (Child care in international perspective) in: Kinderopvang tussen markt en overheid, Welboom 1995

Hagenaars,A.J.M., Homan,M.E. and van Praag,B.M.S.:"Draagkracht-verschillen tussen huishoudens met één resp. twee kostwinners" (Differences in financial capacity between households with one or two breadwinners) in Economisch Statistische Berichten, 20 juni 1984 Pp. $552-559$

Hagenaars,A.J.M. and Wunderink-van Veen,S.R."Soo gewonne, soe verteert" (The economics of the household), Stenfert Kroese Uitgevers, Leiden/Antwerpen 1990.

Harrison,A.:"Major changes proposed for the revised SNA: an overview" in Review of Income and Wealth series 36, nr.4, 1990, p.335-353

Hawrylyshyn,O.:"The value of household services: a survey of empirical estimates" in Review of Income and Wealth, June 1976

Hawrylyshyn,O.:"Towards a definition of non-market activities" in Review of Income and Wealth series 23, p.78-86 1977

Hennipman,P.:"Doeleinden en criteria der economische politiek" (Goals and criteria of economic policy) in "theorie van de economische politiek", red.J.E. Andriessen en M.A.G. Meerhaeghe, Leiden 1962

Hennipman,P."Pareto optimality: Value judgment or analytical tool? in: "Relevance and precision"; essays in honour of Pieter de Wolff" red.J.S.Cramer a.0., Alphen a/d Rijn 1976 pp. $39-69$

Hennipman,P.:"The reasoning of a great methodologist: Mark Blaug on the nature of Paretian Welfare Economics" in De Economist. 1992 nr.4pp.413-446

Hill,T.P.:"On goods and services"in Review of Income and Wealth 1977 p.315-338

Hill,T.P.:"Do-it-yourself and GDP" in Review of Income and Wealth 1979 p.31-39

Hill,M.S.:"Patterns of time use" in in F.T.Juster and F.P. Stafford eds."Time goods and well-being", Michigan, Ann Arbor: Institute for Social Research, University of Michigan 1985 a

Hill,M.S.:"Investment of time in houses and durables" in F.T. Juster,F.T. and F.P.Stafford eds.: "Time goods and well-being", Michigan, Ann Arbor: Institute for Social Research, University of Michigan $1985 \mathrm{~b}$

Hirshleifer, J.:"The expanding domain of economics" in American Economic Review december 1985 pp.53-68

Homan,M.E.:"inkomen tijdsbesteding inkomenswaardering en rechtvaardige inkomen in Nederland. 1991", Ministerie van Sociale Zaken en Werkgelegenheid, Den Haag 1992

Homan,M.E.: "The allocation of time and money in one-eamer and two-earner families; an economic analysis", Alblasserdam 1988

Hooghiemstra,B.T.J. and Niphuis-Nell,M.:"Sociale Atlas voor de Vrouw" (Social A.tlas for women) deel 2, Sociaal en Cultureel Planbureau, Rijswijk 1993 
Jong,A.de:"Positieve actie in arbeidsorganisaties in de Europese Gemeenschap" (Positieve action in labour organizations in the European Community) in "Vrouwen en arbeidsmarktpositieis binnen de Europese Gemeenschap", deel 3, Open Universiteit, Heerlen 1992

Jong, A.de and de Olde,C:"Hoe ouders het werk delen"(How parents share labour), Ministery of Social Affairs and Employment, Den Haag, 1994

jong, V.J. e.a.:"Macro-economische modelbouw in discussie II" (The construction of macro economic models discussed II) in Economisch Statistische Berichten_16.11.1983 p.1072

Joshi,H.: The cost of caring" in "Women and poverty", eds. C.Glendinning and J.Millar, Wheatsfeaf Books LTD., Brighton 1987

Juster,F.T.". A note on recent changes in time use" in "Time, goods and well-being" ed. F.T.Juster and F.P.Stafford, University of Michigan 1985

Juster,F.T. and Stafford,F.P.: "Time, goods and well-being", University of Michigan. 1985

Juster,F.Th.and Stafford,F.P."The allocation of time: empirical findings, behavorial models and problems of measurement" in Joumal of Economic Literature June 1991, p.471-522

Kazemier, B. and Exel,J.:"The allocation of time in the Netherlands in the context of the SNA", Paper for the 22th General Conference of the International Association for Research in Income and Wealth, Voorburg 1992

Kendrick, J.W.:"Studies in the National Income Accounts": 47th Report of the National Bureau of Economic Research, June 1967

Kendrick, J.W.:"Expanding imputed values in the national income and product accounts" in Review of Income and Wealth. December 1979, p. 349-363

Kersten,A.,Jehoel-Gijsbers,G.J.M.,Smit,L.A.H.M.,Siegers,J.J. and Oorschot,W.van:"Samen zonder werk?" (Both unemployed?), Sociale Verzekeringsraad, Zoetermeer 1993

Keuning,S.J.:"Proposal for a Social Accounting Matrix which fits into the Next System of National Accounts" in Economic Systems Research. Vol.3,no.3, 1991 pp.233-247

Keuning,S.J.: "The SAM and Beyond: Open Sesame!" in Economic systems Research vol.6, no.1, 1994 Pp. $21-49$

Keuning,S.J. and de Haan, M.:"Nationale rekeningen en milieu" (National Accounts and the environment) in Economisch Statistische Berichten 12.1 .94 pp.34-39

Killingsworth,M.R. and Heckman,J.J.:"Female labour supply" in: Handbook of Labor Economics volume 1, eds. O.C.Ashenfelter and R.Layard, North-Holland, Amsterdam 1986 chapter 2.

Knulst,W.P.:"Een week tijd" (A week of time use) Den Haag Staatsuitgeverij 1977

Knulst,W.P. en Schoonderwoerd,L.P.H. :"Waar blijt de tijd?" (Where does time go to?) Den Haag Staatsuitgeverij 1983

Knulst,W.P. en Beek,P.van:"Tijd komt met de jaren" (Time comes with age), Rijswijk, Sociaal en Cultureel Planbureau 1990

Kruijk.J.L.de:" Armoede in rijke landen" (Poverty in rich countries) in Economisch Statistische berichted 24.3 .1993 p. $254-267$

Kuipers,S.K.:"Macro-economische modelbouw in dscussie V" (The construction of macro economic models discussed V) in Esonomisch Statische Berichten, 7.12.1983 pp 1140-1143

Kuznets,S: "National income and its composition 1919-1938" National Bureau of Economic Research, New York. 1941

Lancaster,K.J.:"A new approach to consumer theory" in Journal of Political Economy, 74(1966),2, pp. 132-157

Leuthold,J.H.: "Taxation and the value of nonmarker time" in Social Science Research, 1982, 10 pp. 267-281

Lippe,T.van der:"Arbeidsverdeling tussen mannen en vrouwen" (Division of labour between men and women), Thesis Publishers, Amsterdam 1993

Lippe,T. en Niphuis-Nell,M."Ontwikkelingen in de verdeling van onbetaalde arbeid over vrouwen en mannen. 1975-1990" Sociaal en Cultureel Planbureau, Werkdocument 1994

Lützel,H.: "Household production and national accounts" in Statistical Journal of the United Nations 1989 pp. $337-348$ 
Lyubavina,S. and Sokolin,V:'Definition of the household goods and services production sector in national accountssystem of the USSB" Paper for the meeting of national accounts experts OECD, Paris 1991

Maassen van den Brink.H, Gustafsson,S. and Groot,W.:"Kinderopvang tussen markt en overheid" (Childcare between Market and Government) Serie Wetenschappelijke Publikaties Vakbondsmuseum nr.6, Amsterdam 1995

Marshall,A.:"Principles of economics" London, 1890, MacMillan, (eighth edition 1979)

Marx,K.:"Das Kapital" deel I. Verlag Marxistische Blatter, Frankfurt am Main 1976

McCloskey,D:"Some consequences of a Conjective Economics" in "Beyond Economic Man" eds. M.A.Ferber and J.A.Nelson, University of Chicago Press 1993

Meulders,D. and Plasman,R.: Women in atypical employment" Commission of the European Communities 1989

Michael,R.T, Hartmann,H.I. and O'Farrell,B.eds:"Pay equity" National Academy Press, Washington D.C. 1989

Mill,J.S.:"Principles of political economy", The Colonial Press 1900

Millar,J.:"Barriers to equal treatment and equal outcome: Means-testing and unemployment" in "Equal treatment in social security" ISSA Studies and Research nr. 27, Geneva 1988

Mincer,J.:"Labor force participation of married women" in: The economics of women and work" ed. A.H.Amsden, Penguin Education, 1980

Mincer,J. and Polachek,S.:"Family investments in human capital" in "Economics of the family" ed.Th.W. Schultz, University of Chicago Press 1974;

Ministry of Social Affairs and Employment: "Het verschiinsel thuiswerk". (The phenemenon "Outwork"), Den Haag 1984

Ministry of Social Affairs and Employment:"Design of an Equal Rights Policy plan", Den Haag 1985

Ministry of Social Affairs and Employment:"Rapportage Arbeids-markt 1986" (Report of the Labour Market 1986), Den Haag 1986

Ministry of Social Affairs and Employment:"Thuiswerkers en het $2 / 5$ criterium" ("Outwork and the 2/5 criterion), Den Haag 1988

Ministry of Social Affairs and Employment:"Werkboek over de toekomstgerichte strategieën van de Verenigde Naties voor de verbetering van de positie van vrouwen (1985-2000)" (Working document of strategies to improve the position of women in the future), Den Haag 1990 (deel I); deel II:

Ministry of Social Affairs and Employment:"Voortgangsrapportage inzake de positie van vrouwen in de arbeid"(Report about women's labour market position), Den Haag 1994

Ministry of Social Affairs and Employment:"SZW-Nieuws" (News Letter) nr.21 and 221995

Ministry of Social Affairs and Employment:"Onbetaalde zorg geliik verdeeld", Toekomstscenario's Herverdeling Onbetaalde Arbeid (Unpaid work equally distributed: scenarios to redistribute unpaid work), Den Haag 1995

Mitchell, W.C.: "The backward art of spending", American Economic Review 1912, pp269-281.

Moberg,E.:"Voices in the Swedish sex-role Debate" in "VI"no.6 1968

Murphy,M.:"Comparative estimates of the value of household work in the United States for 1976" in Review of income and Wealth March 1982 pp.29-43

Nelson,J.A.:"The study of choice or the study of provisioning? Gender and the definition of economics" in "Beyond Economic Man", eds. M.A.Ferber and J.A.Nelson, The University of Chicago Press 1993

Nerlove,M: in "Toward a new theory of population and economic growth" in "Economics of the family" University of Chicago Press 1974 p. 527

Nooteboom, I. : "Veertig jaren Nationale Rekeningen" (Forty years National Accounts) in "Denken en meten", red.: H.P.H. Brouwer e.a., Centraal Bureau voor de Statistiek Den Haag 1978

Nordhaus, W. and Tobin, J.:"Is growth obsolete?" in "Economic growth" National Bureau of Economic Research, Columbia University Press, General Series 96, New York 1972

Oakley,A.:"Housewife", Penguin Books, Harmondsworth England 1976

Oakley,A.:-"Reflections on the study of household labor" in "Women and household labor" ed. S.Fenstermaker Berk, Sage Yearbooks, Beverly Hills/London 1980 
Odink,J.G.: "Inkomensherverdeling" (Redistribution of income), doctoral thesis, WoltersNoordhoff, Groningen 1985

OECD:Employment Outlook 1988, 1989, 1990, 1994 Paris

OECD:"The integration of women in the economy" Paris 1985

OECD:"Non market household production and its measurement" Paper for the meeting of national accounts experts, Paris 1991

OECD:"Shaping structural change: the role of women" Paris 1992

O'Higgins,M. and Jenkins.S."Poverty in Europe: estimates for 1975, 1980 and 1985" 1989

Op gelijke voet:"Is het kwaad al geschied?" Ministry of social Affairs and Employment, 17e jaargang no.1 January 1996

Palmer,I:"Public finance from a gender perspective" in World Development. December 1995

Pen,J."De consument als producent" (The consumer as producer) in Economisch-Statistische berichten 17.6.1970

Pen,J.:"Een vak met een gat er in" (A profession with a hole") in_Economisch Statistische berichten 8.3.95 p.220-222.

Peskin,H.M. and Peskin,J.:"The valuation of nonmarket activities in income accounting" in Review of Income and Wealth" March 1978 pp.71-91

Philips Nederland N.V.:De Nederlandse huisvrouw", Eindhoven 1966

Plantenga,J. and Sloep,M.J.:"Rekenen met onbetaalde arbeid" (Counting unpaid labour), Emancipatieraad,Den Haag 1995

Pieters,D.C.H.M. and Schell,J.L.M.:"Het sociale zekerheidsrecht van de landen van de Europese Gemeenschap", COSZ, Delft 1990

Polachek,S.W.:"Human capital an the gender earnings gap" preliminary paper for the Conference "Out of the Margin" Amsterdam 1993

Pollak,R.A. and Wachter,M.L.: "The relevance of the household production function and its implications for the allocation of time" in Lournal of Political Economy April 1975, p. 255-277

Pot,L::"Kinderopvang en ouderschapsverlof" (Childcare and parental leave) in "Vrouwen en arbeidsmarkkposities binnen de Europese Gemeenschap part 3, Open Universiteit, Heerlen 1992

Pott-Buter,H.A.:"Eacts and fairy tales about female labor, family en fertility". Amsterdam University Press 1994

Pujol,M:"Feminism and anti-feminism in early economic thought". Edward Elgar 1992

Pyatt,G.:"Accounting for time use" in Review of income and Wealth 1990 p. 33-52.

Pyatt,G. and Round,J.I., eds. "Social Accounting matrices: a basis for planning". World Bank, Washington 1985

Pyatt,G. and Thorbecke,E.:"Planning techniques for a better future" I.L.O, Geneva 1976

Rathbone,E.F.:"The desinherited family", Edward Amold \& Co, London 1924

Reid,M.The economic contribution of homemakers" in The Annals of the American Academy of political and social sciences Philadelphia may 1947 pp.61-69

Renaud,P.S.A and Siegers,J.J.:"Welvaartsverschillen tussen echtparen met één verdiener en echtparen met twee verdieners" (Differences in welfare between one- and two earner couples) in Beleid_en Maatschappij 1984, pp.66-70

Reynolds,F.D.,Crask,M.R. and Wells,W.D.:"The modern feminine life style" in Ioumal of Marketing. July 1977 pp. $38-45$

Robbins,L:"The nature and significance of economic science", London, MacMillan, 1962

Robinson,J.P.:"Housework technology and household work" in: "Women and household labor" ed. S.Fenstermaker Berk, Sage Publications 1980, pp.53-69

Rosen,H:"The monetary value of a housewife: a replacement cost approach" in American Journal of Economic Society january 1974 p.65-73

Ruggles,R.: The system of National Accounts: review of major issues and proposals for future work and short termschanges" United Nations Statistical Office, 1982

Ruggles,R:"A note on the revision of the United Nations system of National Accounts" in Review of Income and Wealth series 36, no.4, December 1990 p.413-419

Ruggles, R: "Review of total incomes system of accounts by Robert Eisner" in Review of Income and Wealth, december 1991 p.455-460 
Säntti,R:"Unpaid houseworktime use and value", Ministry of Social Affairs and Health, Helsinki 1982

Schäfer,D.:"Concepts and plans for a satellite system for houschold production". Paper for the Conference of the International Association for Research in Income and Wealth, Switzerland 1992

Schettkat,R.:The size of household production: methodological problems and estimate for the FRG", in Review of Income and Wealth september 1985 pp.309-321

Schiepers,J.M.P.,Van Gessel-Dabekausen,A.A.M.W. and Elkink,A.J.: "Equivalentiefactoren volgens de budgetverdelingsmethode" Uitkomsten gebaseerd op het CBS-Budgetonderzoek 1986-1990 (Equivalence factors according to the budget distribution method: results based on the SN-budget-research 1986-1990), Onderzoek in opdracht van het Ministerie van Sociale Zaken en Werkgelegenheid door Centraal Bureau voor de Statistiek, Heerlen 1993

Schippers,J.J.:"Beloningsverschillen tussen mannen en vrouwen" (Wage differences between men and women), Wolters-Noordhoff 1987

Schultz,Th.W.ed.:"economics of the family: marriage, children and human capital" A Conference Report of the National Bureau of Economic Research, University of Chicago Press 1974

Seel,B. and Hufnagel,R.:"Intra-household division of labour and the female labour supply", Paper to the 22nd General Conference of the International Association for Research in Income and Welath, Switzerland 1992

Sen,A."On economic inequality" Clarendon Press, Oxford 1973

Sen,A.:"Rational fools: a critique of the behavioural foundations of economic theory" in "Choice. welfare and measurement" Basil Blackwell, Oxford 1982

Shamseddine,A.H.:"GNP Imputations pf the value of housewives' services" in Economic and Business Bulletin 1967 p. 52-61

Singer, $\mathbf{E}$ ::"Kinderopvang, goed of slecht?" (Childcare, good or bad?) Uitg.SWP Postbus 7583500 AN Utrecht

Sirageldin,I.A.: Non-market components of national income" Institute for Social Research, University of Michigan Ann Arbor 1969

Smith, A."The wealth of nations", Ed. A.Skinner, Penguin Books, LTD, Harmondsworth, Middlesex, England 1974

Sociaal-Economische Raad (SER):"Emancipatie als zesde doel-stelling" (Emancipation as a sixth objective), Den Haag 16.12.1988

Solow,R.M.:"Feminist theory, women's experience, and economics" in "Beyond_Economic Man" eds.M.A.Ferber and J.A.Nelson, The University of Chicago Press 1993

Sorensen,E.:"Measuring the effect of occupational sex and rave composition on earnings" in "Pay Equity", eds. R.T.Michael, H.I.Hartmann and B.O'Farrell, National Academy Press, Washington D.C. 1989

Sorensen,A. and McLanahan,S.:"Married women's economic dependency" in AJS Volume 93 number 3 , University of Chicago 1987 pp. 659-686

Stafford,F.P. and Duncan,G.J.:"The use of time and technology by households in the United States" in:"Time, goods and well-being". ed. F.T.Juster and F.P.Stafford, University of Michigan 1985

Statistical Commission and Economic Commission for Europe Conference of European Statisticians:"GDP as a measure of output: problems and solutions", 1981

Statistics Canada:"Estimating the value of household work in Canada", Paper for the meeting of national account experts, Paris 1991

Statistics Netherlands (Centraal Bureau voor de Statistiek): "Statistisch Zak- en Jaarboek 1977 $t / m 1994$ Den Haag

Statistics Netherlands (Centraal Bureau voor de Statistiek): "Eersonele inkomensverdeling 1985" (Personal income distribution 1985), Den Haag 1989

Statistics Netherlands (Centraal Bureau voor de Statistiek):"De tijdsbesteding van de Nederlandse bevolking Kemcijfers 1987" (Time use of the Dutch population, 1987) Voorburg 1989 
Statistics Netherlands (Centraal Bureau voor de Statistiek): "Consumer confidence in the Netherlands 1972-1991" in Supplement bij de Sociaal-Economische Maandstatistiek jaargang 1991,nr.1, pp 24-35 (a)

Statistics Netherlands (Centraal Bureau voor de Statistiek): "National Accounts 1990" Den Haag 1991 (b)

Statistics Netherlands (Centraal Bureau voor de Statistiek): "Personele inkomensverdeling 1990" (Personal income distribution 1990) SDU/Uitgeverij Den Haag 1993 (a)

Statistics Netherlands (Centraal Bureau voor de Statistiek): "Kinderopvang: gebruik en gebruikers" (Childcare: use and users) in Sociaal-Culturele Berichten 1993-11 (b) Voorburg/Heerlen

Steunpunt Thuiswerk:"Beroep: thuiswerkster" (Profession: outworker),Hengelo. 1987'

Steunpunt Thuiswerk: "Balans van thuiswerk" (Balance of outwork),Hengelo 1988

Steunpunt Thuiswerk:"Thuiswerk in Twente" (Outwork in Twente),Hengelo 1990

Stoop,I.A.L. and Oudhof,J.:"Tijdsbesteding van paren" (Time use of couples) in Sociaal-Culturele Berichten Centraal Bureau voor de Statistiek, 1990-3

Stoop,I.A.L.:"Alles heeft zijn uur; tijdsbesteding per dag van de week en uur van de dag" (Time use per day and hour) in Sociaal=Culturele Berichten Centraal Bureau voor de Statistiek, 1990-13

Stone,R:"Measurement of National Income and the Construction of social accounts", report of the Sub-committee on National Income Statistics of the League of Nations Committe of Statistical Experts, United Nations, Geneva 1947

Stone,R::"Working with what we have: how can existing data be used in the construction and analysis of socio-demographic matrices?" in Review of Income and Wealth series 28, no.3, 1982 p.291-303

Strober,M.H.: "Wives' labor force behavior and family consumption" in American Economic Review.vol. 67.no.1 February 1977, pp.410-417, reprinted in "The economics of women and work" ed.A.H.Amsden,Penguin Education 1980, England

Studenski,P.:"The income of nations" New York 1958

Sullerot,E:"Geschiedenis van de vrouwenarbeid" (History of women's labour), Paul Brand, Bussum 1969

Suviranta,A.: "Determining the value of unpaid housework", Ministry of Social Affairs and Health Research Department, Helsinki 1986

Szalai,A.:"The use of time: daily activities of urban and suburban populations in twelve countries", Mouton, Den Haag 1972

SZW-Nieuws:"Positie vrouwen en mannen in arbeidsproces nog lang niet gelijk", Den Haag 23.11.1995

Theobald, R, and Brand,P.:"Gewaarborg inkomen in een vrije maatschappii" (Guaranteed income in a free society), Werkgroep 2000, 1976

Tijdens,K.,Maassen van den Brink,H., Noom,M. and Groot,W.:"Arbeid en zorg." (Labour and Care), OSA-Werkdocument W 124, Den Haag 1994

Tinbergen, J.:"Macro-economische modelbouw in discussie" (The construction of macro economic models discussed) in Economisch Statistische Berichten 30.11 .83 p.1120

Traa,P.C.van:"Geschiedenis van de esonomie" (History of economics), Amsterdam, De Bussy 1969

Tweede Kamer, vergaderjaar 1989-1990, stuk 2i 505, nr.2; deel III: Ecosoc-resolution 1990/15.

Tweede Kamer der Staten-Generaal, stuk nr. 23 231:"Voorstel van wet tot wijziging van de Wet op de inkomstenbelasting 1964 en dde Wet op de Loonbelasting 1964 met het oog op een beperking va de mogelijkheden tot overdracht van de basisaftrek in het kader van het streven naar een verdergaande individualisering", (Bill to restrict breadwinnerfacilities in Tax Law) Den Haag 1992-1993

United Nations:"A system of national accounts" series F,no.2, rev.3 New York 1968

United Nations: "World Action Plan for the realisation of the goals of the international Women's Year 1975" Mexico-City 1974

United Nations:"Towards a system of Social Demographic Statistics", series E. no.18. New York 1975 
United Nations:"The feasibility of welfare-oriented measures to supplement the national accounts and balances: a technical report" Series F, nr.22, New York 1977, p.69

United Nations:"Gross domestic product as a measure of output", Statistical Commission and Economic Commission For Europe, 1979

United Nations: "World Conference about the position of women" Copenhagen 1980

United Nations:"Equality, development and peace": report of the World Conference to Review and Appraise the Achievements of the United Nations Decade for women, UN-document, A/Conf.116/28/rev. I, 1986

United Nations:"Implications of the Nairobi Forward-Looking Strategies for the Advancement of Women for Programma Planning in the United Nations System" Commission on the Status of Women, item 3 on the provisional agenda 1987 (a)

United Nations:"Measuring and valuing women's participation in the informal sector of the economy" Conference of European Statisticians, Working Paper no.6, 7 and 8, 1987 (b)

United Nations:"Revised System of National Accounts" Chapter XX "Social Accounting Matrices", 1992

United Nations:"Human Development Report 1995, New York 1995

Vanek.J. "Time spent in housework" in "The economics of women and work". ed.A.H.Amsden, Penguin Books, Harmondsworth England 1980

Vendrik,M.:"Collective habits and social norms in labour supply", Universitaire Pers Maastricht 1993

Vleuten,T.van:"Wetgeving binnen de EG" (Legislation in the EC) in "Vrouwen en arbeidsmarktposities binnen de Europese Gemeenschap. part 3, Open Universiteit, Heerlen 1992

Waring,M.:"If women counted" Harper, SanFrancisco 1990

Wartna, J.A. "Bouw en gebruik van econometrische modellen" (Construction and use of econometric models), Universitaire pers Rotterdam 1974

Weinrobe,M.:"Household production and national production: an improvement of the record" in Review of Income and Wealth 1974, p. 89-100

Wetenschappelijke Raad voor het Regeringsbeleid:"Vernieuwingen in het arbeidsbestel", (Renewals in the organisation of the labour market) Staatsuitgeverij, Den Haag 1981

Wetenschappelijke Raad voor het Regeringsbeleid:"Beleidgerichte toekomstverkenning" (A prognosis of the future with an eye on policy making) Deel II, Staatsuitgeverij, Den Haag 1983

Wetenschappelijke Raad voor het Regeringsbeleid:"Waarborgen voor zekerheid: Een nieuw stelsel van sociale zekerheid in hoofdlinen" (Warrants for security: main lines of a new system of social security) Den Haag 1985

Wetenschappelijke Raad voor het Regeringsbeleid:"Een werkend perspectief, arbeidsparticipatie in de jaren '90" (A working perspective, labour market participation in the nineties), Den Haag, SDU 1990

Wibaut-Berdenis van Berlekom,M.: Naar het land der vrijheid". (To the land of freedom), Amsterdam 1928

Wibaut-Berdenis van Berlekom,M.:"Herinneringen". (Memories),De Trommel, Amsterdam 1976

Willborn,S.L. red.:"Economic and legal perspectives on womeri's wages in six countries".JAI. Press Inc. 1991

Wilbrink-Griffioen,D.,Vliet,I.van and Elzinga,A.:"Kinderopvang en arbeidsparticipatie van yrouwen" (Childcare and labourmarket participation of women), Den Haag 1987, Ministerie van Sociale Zaken en Werkgelegenheid

Wolff,E.N.:"The size distribution of household disposable wealth in the US" in Review of Income and Wealth june 1983

Wolff,P.de:"Jan Tinbergen als modelbouwer" (Jan Tinbergen as a model constructor) in Economisch. Statistische berichten. 13.4.1984 pp.308-311

Woolley,F.:"Feminist ideology and welfare economic", paper prepared for the International Conference "Out of the Margin", the Netherlands 1993

Zalm,G.:"Modellen en economische politiek" (Models and economic policy), Stichting voor Publieksvoorlichting over Wetenschap en Techniek, Utrecht 1988 
Zienkowski,L.:"Short remarks on the Polish experience with estimates of the value of unpaid household production" Paper for the meeting of national accounts experts OECD, Paris 1991

Zimmerman,L.J.:"Geschiedenis van het economisch denken" (History of economic thought), Den Haag, Albani 1963 


\section{INDEX}

\section{Activities}

consumptive $23,27,30$

economic 21, 23, 39, 94, 166

educational 29

household $47,48,54,77,78,95,158$

joint or multiple 43, 55

leisure $13,25,26,28,35,56,57,58$

non-economic 23

primary 43

productive $16,41,47,56,75,80$

secondary 43

voluntary $51,56,58$

Added worker effect 92

Adjustment policy 102

Advisory Council on Governement Policy (WRR) 166, 168

Affirmative (positive) action 187, 188, 189

Altruism 15, 101, 151

Anglo-American School 21

Atypical employment 186

Basic income 168, 169, 170, 191, 195

Breadwinner (main and second) $69,70,71,109,110,111,112,113,115,116,129,130,132,134,135,142$, $148,169,178,179,180,183,185,186$

Breadwinner's supplementary benefits 183

Budget constraint 28, 29, 35, 129, 142

Business cycle (model) 73, 79, 92, 126, 140

Calamity leave 174

Capital goods (durable commodities) 22, 29,49, 77, 81, 99, 128, 141, 174

Care

independence $148,149,154,158,160,195$

of family $23,70,56,66,67,68,70$

Central Planning Bureau (CPB) 17, 125, 129, 144, 168, 174, 179

Child care $30,34,36,44,46,56,57,68,78,95,98,99,117,128,130,131,141,150,151,152,162,163,164$, $167,170,171,172,174,175,176,177,180,181,182,187,188$

Children's allowance 180,181

Classical economists 21

Collective

services 43,100

spending 102,169

Commodities 22, 29, 34, 47, 77, 101

Comparable worth 156,189

Consumption $13,16,17,21,22,24,25,26,27,28,29,30,31,32,34,35,36,38,39,41,43,44,47,57,73,74$, $75,76,77,78,80,81,82,83,84,85,88,89,91,92,98,99,101,103,104,108,117,125,128,129,130,140$, $141,142,144,150,166,167,174,193,195$

Cyclical fluctuations 77

Diary (instrument) 42, 43, 45, 55, 111, 112

Direct output approach 48

Discouraged worker effect 92

Discrimation 23, 156, 187, 188, 189

Dissaving 128

Do-it-yourself activities 53, 56, 58, 67, 68, 70, 76, 147, 148 


\section{Economic}

approach 22

contraction 128

expension 128

growth (rate) 13, 16, 73, 89, 126, 157, 170, 193, 194

independence $15,17,145,147,148,149,150,151,152,153,154,157,158,159,160,161,166,167,169$, $170,175,191,193,195$

policy $13,14,127,157,158$

Economically active population $93,123,148,155,156$

Economies of scale 43, 44, 45, 106, 108, 113

Efficiency 44, 94, 100, 102, 176

Elderly people23, 48, 62, 77, 91, 131, 162, 163, 164, 167, 169,170, 177, 180

Employment 16, 38, 73, 78, 92, 93, 95, 96, 97,98, 103, 126, 133, 140, 148, 149, 155, 156, 157, 167, 169, 174 , $183,184,185,186,187,188,190,193$

Employment rate 98

Engender 16, 159

Equal

opportunities 155, 156, 171, 187

pay for equal work 165

rights $147,161,171$

treatment $171,184,187,190$

wage act 187

Equity 100, 102, 175, 176, 189

Equilibrium model $127,128,129$

Equivalence scale 106, 108, 110, 113, 117, 118

European

Commission $95,159,186,187,188$

Parliament 159, 160

Expansion 23, 92, 128

Extended income 105, 109, 110, 111, 113, 114, 115, 116, 117, 118, 123, 124

Family allowance $164,165,166,179$

Financial independence 148, 149, 152, 153, 154, 159, 161,167, 170, 191, 195

Flexible working hours 190, 191

Formal economy $80,128,144$

Full-time 95, 96, 170, 179, 186, 191

Gender

blind $15,16,103$

equality $156,157,160$

related Development Index (GDI) 156, 157, 160

Gini coefficient 107, 111

Government

expenses $73,128,144$

policy 131, 132, 171, 177, 131, 132, 143, 171,177,

production 78

programmes 77,141

purchases 77

Growth cycles 127

Guaranteed income 168,169

Handicapped (person/people)25, 32, 37, 91, 94, 103, 131, 143, 144, 177, 193

Health care 23, 77, 103, 127, 131, 141

Home care 68,177

Homemaker's paradox 36 


\section{Household}

help (paid) 59, 70, 99, 101, 128, 133, 141, 143, 144, 150,152, 182

model 129,132 ,

production (function) $30,33,35,38,41,44,47,48,51,75,76,79,81,82,83,84,85,89,90,91,92,98,99$, $103,105,107,109,110,111,117,118,123,124,128,129,133,134,135,136,137,141,142,143,150$, $151,177,178,182$

work $23,25,28,36,41,42,44,49,50,51,54,56,57,66,67,68,70,71,73,74,75,77,78,89,95,9697$, $102,109,111,128,152,159,165,166,167,177,180,181,194$

Housewife/-wives $24,25,37,42,44,49,54,59,75,77,93,94,129,140,148,149,164,165,167,168,182$, $183,184,195$

Human capital revolution (Theory) 25

Human Development Index (HDI) 156, 157

Income

inequality $105,106,107,110,111,121,122,123,124,195$

in kind $27,83,85,107$

tax rate 128

transfers 82,83

unit 105,106

Individualization $178,180,181,184$

Inequities 185

Informal

care $56,77,117,175$

(household) sector $76,80,128$

Input method $35,41,42,43,45,46,48,49,51,52,59,193,194$

International Labour Organization (ILO) 187

International Women's Conference $77,158,160,165,187$

Investment (in household) 81,99

Job evaluation 189

Joint taxation 178

Labour

contract 170

market participation54, 62, 64, 66, 90, 92, 116,130, 133, 139, 140, 150, 154, 159, 161, 162, 164, 165, $167,170,171,172,175,176,177,180,182,184,185,189,191,194$

supply $35,129,130,133,140,142,144,148,167,169,174,179,180,181,183,195$

Labor value approach 48

Leisure time $28,32,33,35,38,39,42,53$

Macroeconomic

model(s) 17, 125, 126,127, 132, 140, 141, 144

policy 102, 103

Male-chauvinist model 35, 130, 169

Marriage relief $179,180,181$

Maternity leave 173

Market (replacement) costs (approach) 36, 38, 39, 41

Maximum (complete) economic independence 148

M-countries 163,164

Means tested (assistance) 162, 183, 184

Minimum

economic independence 148

subsistence benefit 152

Monetary income 76

National Accounts $16,27,38,41,51,52,63,73,74,75,77,78,79,80,81,88,90,92,95,97,98,99,103$, $104,140,144,147,158,159,160,194$

Negative income tax $161,168,169$ 
Nonmarket

activity $15,41,76,77$

household work 78

output 76,92

New Home Economics 13, 16, 21

Older women $32,64,66,103,152$

One- and-a-half earners strategy 136

One-earner (household, family) $69,70,99,108,109,110,113,114,115,116,117,118,119,120,121,122$. $123,124,136,137,138,139,172,180,181,183,184,185,190,191,195$

One-parent (household, family)69, 70, 78, 103,108,110, 111, 112, 113, 114, 115, 116, 118, 119, 120, 121, $122,124,134,135,137,138,139,158,159,162,169,170,184$

Opportunity costs (approach) 36, 38, 39

Organization for Economic Cooperation and Development (OECD) 150, 62, 74, 75, 78, 95, 96, 97, 106 , $108,109,113,117,118,119,155,156,158,158,160,170,177,178,182,183,185,186$

Dutput method $35,41,45,46,51,193,194$

Outwork 94, 95

Parental leave $162,171,173,174$

Pareto optimal 73,100

Participation rate $59,94,130,132,139,154,185$

Part-time (work) 94, 95, 131, 135, 150, 152, 155, 164, 164, 172, 174, 183, 184, 185, 186, 190, 191

Peak-countries 163

Pensions 22, 80, 83, 84, 85, 95, 103, 161, 183, 185, 186, 187

Personal care $13,14,23,26,32,39,56,57,58,193$

Personal Income Distribution 17

Physiocrats 21, 24

Plateau countries 163,164

Pollution 78, 127

Positive (affirmative) action 187, 188, 189

Privafe sector $127,130,164$

Privatization 103,127

Production boundary 24, 56, 79, 80

Productive consumption 26, 27

Productivity (unpaid or paid work) 25,36, 38, 39, 44, 45, 49, 55, 58, 59, 62, 78, 174, 180

Public sector 103, 127, 162, 163

Redistribution of unpaid work $172,182,183$

Replacement costs $36,38,39$

Reservation wage $37,111,131$

Revealed preference 101

Satellite account $76,80,104,194$

Savings $74,80,81,84,85,87,88,89,98,128,129,140,141,193,195$

Sectorial model 127

Self-interest 21,22

Service costs 36

Sex

contract 170

segregation $156_{8}, 177,188$

Sexual intimidation 171,190

Shadow price/wage 16,102

Shopping 27, 37, 46, 57, 66, 67, 68, 70, 99, 106

Shortening of working hours/week $128,173,191$

Single people/person $69,105,108,110,111,113,114,115,116,117,118,119,120,121,122,123,124,134$, $135,137,139,143,144,152,167,169,172,178,180,184$

Single parent $108,110,119,123,138,139,143,152,195$

Social and. Cultural Planning Office (SCP) 13, 26, 53, 54, 55, 56, 57, 58, 64, 70, 132, 172 
Social and Economic Council (SER) 158

Social

contract 170

security $22,36,38,49,51,52,56,58,59,61,62,63,70,74,80,81,82,83,85,95,102,105,126,127,129$. $130,139,141,158,159,161,162,166,167,168,171,174,180,182,183,184,186,187,190,191,193$, 194 ,

Socialist economists 21

Stagflation 127

Structure model 126

Subsidies 51, 62, 63, 80, 87, 102, 103, 175, 177, 188, 189, 190, 191

Subsistence activitie $76,77,78,91$

Tax policy $177,178,181$

Temporary jobs/work $95,97,186$

Theill coefficient $107,121,122,123$

Time

constraint $29,30,32,130,142$

use study (survey, research) $14,15,16,42,43,44,46,47,50,51,52,53,54,55,57,58,59,66,69,70$, $75,80,81,94,111,115,116,118,120,121,133,142,144,152,172,181,194$

Third person criterion $25,27,30,39,47,56,58$

Total workload $13,53,63,65,66,136,194$

Two-earner (household/family) 54, 69, 70, 99, 108, 109, 110, 111, 112, 113, 114, 115, 116, 117, 118, 119, $120,121,122,123,124,134,135,136,137,138,139,172,180,181,191$

Underground sector 128

Unemployment (rate) $60,67,94,96,97,98,123,155,184,186,190$

Utility function $28,35,101,128,129,130,141,142,150,151$

Value Added Tax (VAT) 46,182

Value of unpaid work $14,16,17,25,37,39,41,44,45,49,51,53,55,58,59,61,62,63,70,73,74,75,77$, $80,81,88,89,90,98,104,105,112,114,115,116,119,121,122,123,124,141,154,160,193,194,195$

Variance of logarithm 107, 110, 111

Voluntary work $13,15,23,44,51,54,56,58,67,68,70,81,83,84,85,88,107,128,130,134,135,136$, $137,141,142,143$

Wage

gap $62,156,186,187$

for mothers 165,166

moderation 128

Welfare (state) $16,17,21,22,24,25,28,38,73,75,77,79,89,91,92,100,101,102,105,106,107,108$, $110,114,115,117,123,140,141,151,158,159,161,162,163,164,168,171,173,177,180,191,195$

Widows pension 185

Women's work / work of women 15, 78, 96,105, 158

Women's position 15, 95, 157, 164, 188, 191 



\section{CURRICULUM VITAE}

Marga Hundt was born on 28 April 1931 in Amsterdam. After completing her secondary education (HBS-A) at the R.F.B. at Amersfoort, she studied economics at the University of Amsterdam and graduated in 1954. Three weeks after her final examination she married Koenraad Thomas Bruyn and had a son and a daughter. She worked for seven years for a consumers' organization as a member of scientific staff. After that she taught economics at several schools for secondary education during fifteen years and in 1975 she joined the Faculty of Economy at the University of Amsterdam as an Assistant Professor, where she left in 1995. From 1981-1989 she was a member of the Emancipatieraad (Commission for Equal Rights and Opportunities for Women) and from 1983-1989 she was a member of the editorial staff of "Sociaal Maandblad Arbeid" and moreover she held positions on the board of a number organizations. In 1994 she became chairwoman of the State Commission "Scenario's Herverdeling Onbetaalde Arbeid" (Scenarios Redistribution Unpaid Work"), which Commission presented its advice to the Dutch Government in autumn 1995.

She published several books: "Deeltijdwerk" (1982), "Huishouden = onbetaalde arbeid, maar huisvrouwenloon geen oplossing" (1985), "Vrouwen op de arbeidsmarkt: Nederlandse situatie in de jaren tachtig en negentig" (1988), and she published over seventy articles and contributions to scientific books and magazines on women's positions in paid and unpaid work.

In 1989 she was decorated "Officier in de Orde van Oranje Nassau" by her Majesty the Queen of the Netherlands. In 1990 she was awarded the first "Aletta Jabobsprijs" by the University of Groningen and in 1995 the "Stapenning" of the University of Amsterdam for special services. Since 1995 she has lived in Switzerland. 


\section{CURRICULUM VITAE}

Marga Hundt werd op 28 april 1931 geboren te Amsterdam. Na het HBS-A diploma behaald te hebben aan de R.H.B. te Amersfoort, werd zij in november 1954 toegelaten tot de promotie aan de Economische Faculteit van de Gemeente Universiteit te Amsterdam. $\mathrm{Zij}$ trouwde drie weken na haar doctoraal examen met Koenraad Thomas Bruyn en kreeg een zoon en een dochter. Zij was zeven jaar als wetenschappelijk medewerkster werkzaam voor een consumentenorganisatie. Daarna was zij als docente economie gedurende vijftien jaar verbonden aan verschillende scholen voor middelbaar onderwijs en trad zij in 1975 in dienst als wetenschappelijk medewerkster bij de Economische Faculteit van de Universiteit van Amsterdam, waar zij in 1995 afscheid nam. Zij was van 1981-1989 lid van de Emancipatieraad en van 1983-1989 lid van de redactie van Sociaal Maandblad Arbeid en bekleedde daarnaast een aantal bestuurlijke functies. In 1994 werd zij voorzitter van de Staatsconmissie "Scenario's Herverdeling Onbetaalde Arbeid", die zijn advies in het najaar van 1995 aan de Regering uitbracht.

Boeken van haar hand zijn: "Deeltijdwerk" (1982), "Huishouden $=$ onbetaalde arbeid, maar huisvrouwenloon geen oplossing" (1985), "Vrouwen op de arbeidsmarkt: Nederlandse situatie in de jaren tachtig en negentig" (1988). Zij publiceerde meer dan 70 artikelen en bijdragen aan wetenschappelijke boeken en bladen over de positie van vrouwen in betaalde en onbetaalde arbeid.

In 1989 werd zij benoemd tot Officier in de Orde van Oranje Nassau, in 1990 ontving zij als eerste de Aletta Jacobsprijs van de Rijksuniversiteit Groningen en in 1995 de Stapenning van de Universiteit van Amsterdam wegens bijzondere verdiensten. Sinds 1995 woont zij in Wallis (Zwitserland). 


\section{SAMENVATTING}

Mensen in ontwikkelde landen besteden ruim $40 \%$ van alle beschikbare tijd in hun leven aan persoonlijke verzorging (eten, slapen, hygiëne enz.), 25 a $30 \%$ aan vrije tijd (T.V. kijken, sport enz.) en 25 à $30 \%$ aan arbeid. Bij arbeid denken de meeste mensen automatisch aan "betaalde" arbeid. Dat is merkwaardig omdat het aantal uren onbetaalde arbeid 1 à $1,5 \times$ zo groot is als het aantal betaalde uren arbeid. Het aandeel van vrouwen in de onbetaalde arbeid is in alle landen aanzienlijk groter dan dat van mannen.

De centrale vraag in deze studie is wat de economische waarde van onbetaalde arbeid economische waarde. Een tweede vraag is wat de consequenties zijn als deze waarde meegeteld wordt bij het bepalen van economische grootheden zoals productie en consumptie, economische groei, werkgelegenheid en werkloosheid, de personele inkomensverdeling e.d. Deze vragen worden behandeld in deel $L$.

Deel II behandelt de vraag welke invloed de ongelijke verdeling van onbetaalde arbeid over mannen en vrouwen heeft op de economische zelfstandigheid en daarmee op de maatschappelijke positie van mannen en vrouwen. Kan de economische zelfstandigheid veranderd worden zonder de ongelijke verdeling van onbetaalde arbeid te veranderen?

In hoofdstuk 2 wordt de groeiende aandacht van de economische wetenschap voor onbetaalde arbeid behandeld. De Amerikaanse economen Mincer, Becker en Gronau maakten duidelijk, dat de gezinshuishouding zowel een productie- als een consumptiehuishouding is. Onbetaalde arbeid legt beslag op schaarse menselijke tijd, die ook voor andere doeleinden aangewend kan worden. Hoewel onbetaalde arbeid geen markt passeert, kan de waarde geschat worden door te kijken naar een marktsubstituut. Als onbetaalde arbeid kan iedere menselijke activiteit aangeduid worden die door een derde persoon verricht kan worden. Het gaat daarbij niet alleen om de waarde van onbetaalde arbeid van mensen die daarnaast betaalde arbeid verrichten, maar evenzeer om de waarde van onbetaalde arbeid van mensen die buiten het betaalde arbeidsproces staan omdat zij te jong,te oud, werkloos of gehandicapt zijn. Het verrichten van onbetaalde arbeid levert voor deze mensen immers besparingen op, die waarde hebben.

Hoofdstuk 3 behandelt verschillende methoden om de waarde van onbetaalde arbeid te bepalen. De "input-methode" gaat uit van het aantal onbetaalde uren en vermenigvuldigt deze met een uurprijs. Die uurprijs kan zijn een prijs die op de markt betaald wordt voor een arbeidskracht, die de onbetaalde werker kan vervangen. De uurprijs kan zijn bruto of netto of bruto plus werkgeverspremies in de sociale zekerheid. Een andere benadering is te kijken naar het loon dat de onbetaalde werker netto derft door niet op de arbeidsmarkt te werken, de z.g. "opportunity costs". De "output-methode" gaat uit van de waarde die de met onbetaalde arbeid geproduceerde goederen en diensten op de markt zouden 
hebben. De macro-schattingen van de waarde van onbetaalde arbeid in de economische literatuur lopen uiteen van 6 tot $72 \%$ van het Bruto Nationaal Product, afhankelijk van de gevolgde methode, het aantal personen en de leeftijden van de personen die geacht worden onbetaalde arbeid te verrichten, de activiteiten die tot de onbetaalde arbeid worden gerekend en de prijs die voor de schattingen wordt gebruikt. Omdat tijdsbestedingsonderzoeken beschikbaar zijn, in tegenstelling tot data voor de output methode, koos ik de input methode. Bruto lonen plus werkgeversbijdrage van een algemene vervanger zijn gekozen als prijscomponent omdat deze ook in de Nationale Rekeningen worden gebruikt.

De berekening van de waarde van onbetaalde arbeid in Nederland in hoofdstuk 4 is gebaseerd op de "input-methode", zoals deze blijkt uit het aantal uren onbetaalde arbeid in tijdbestedings-onderzoeken uit de jaren 1975, 1980, 1985 en 1990. Deze tijdbestedingsonderzoeken zijn onderling vergelijkbaar ondat steeds eenzelifde vragenlijst en methode is gebruikt. De onbetaalde uren arbeid van de gehele Nederlandse bevolking van 12 jaar en ouder worden vermenigvuldigd met drie verschillende bruto uurlonen inclusief de werkgeverslasten, nl. het wettelijk minimum(uur)loon, het loon van een gezinsverzorgster in loonschaal 12 en het gemiddeld verdiende loon in het betreffende jaar. Het resultaat van deze berekeningen is een waarde voor de gehele bevolking van 1.2 jaar en ouder die variëeert van 51 tot $110 \%$ van het BNP, afhankelijk van het geschatte loon. Wordt uitsluitend gekeken naar de waarde van onbetaalde arbeid van de bevolking van 25-64 jaar, dan is de waarde van de onbetaalde arbeid 36 tot $78 \%$ van het BNP, afhankelijk van het geschatte loon. Deze percentages liggen hoger dan die van schattingen in andere landen, omdat tijdens de onderzoekperiode de arbeidsmarktparticipatie van Nederlandse vrouwen lager was dan elders en in dit onderzoek het bruto loon inclusief werkgeverspremies werd gebruikt voor de schattingen in plaats van het netto loon. Het aandeel van het onbetaalde werk in alle werk nam toe tot 1985 maar was in 1990 lager dan in 1975. Het aantal uren onbetaalde arbeid van mannen nam toe, dat van vrouwen bleef ongeveer gelijk. De totale werklast aan betaald en onbetaald werk was hoger voor vrouwen dan voor mannen in alle leeftijdsgroepen, met uitzondering van de leeftijdsgroep $35-49$ in 1985 en 1990. De werklast van oudere vrouwen was aanzienlijk hoger dan die van oudere mannen. In de onderzochte periode steeg het aantal arbeidsuren van vrouwen, terwijl dat van mannen daalde. Huishoudelijk werk vraagt de meeste onbetaalde arbeidsuren.

Sinds het ontstaan van de Nationale Rekeningen in de jaren twintig van deze eeuw discussiëren economen en statistici over de vraag of onbetaalde arbeid in de Nationale Rekeningen opgenomen zou moeten worden. De argumenten pro en contra worden behandeld in hoofdstuk. 5 . Tevens wordt aangegeven op welke wijze het onbetaalde werk in de Nationale Rekeningen opgenomen zou kunnen worden. Mijn conclusie is dat de problemen die implementatie van de waarde van onbetaald werk in de Nationale Rekeningen met zich meebrengt, overwonnen kunnen worden door oude en nieuwe waarden gedurende een 
overgangsperiode naast elkaar te presenteren. Opneming van deze waarde in een Addendum of een Satelliet Rekening zie ik als een eerste stap in de richting van implementatie. Indien de waarde van onbetaalde arbeid in de Nationale Rekeningen verwerkt zou worden, zouden allerlei economische grootheden veranderen. Als de onbetaalde arbeid in de economische statistieken zou worden opgenomen zou de economische groei per hoofd van de bevolking in de periode 1975-1990 in zeven van de negen berkeningen lager zijn geweest. Conjuncturele schommelingen zouden minder groot zijn, de beroepsbevolking zou $45 \%$ hoger zijn, de werkloosheid zou eveneens hoger zijn, terwijl de totale consumptie en de investeringen in $199075 \%$ hoger zouden zijn geweest en de besparingen $60 \%$. Optimale Pareto allocatie zou een andere inhoud krijgen.

Als indicator voor de individuele welvaart wordt meestal de personele inkomensverdeling gebruikt, rekening houdend met de verschillende omvang en samenstelling van gezinshuishoudingen. De wijziging die de personele inkomensverdeling ondergaat als rekening wordt gehouden met de waarde van onbetaalde arbeid, is het onderwerp van hoofdstuk 6. De inkomens van alleenverdieners en alleenstaande ouders blijken daardoor te verdubbelen. De inkomensongelijkheid tussen verschillende typen huishoudens vermindert met 56 tot $62 \%$ als de waarde van de onbetaalde arbeid wordt meegeteld.

In macro-economische modellen wordt de onbetaalde arbeid niet als variabele opgenomen. In hoofdstuk 7 wordt dit als een gemis aangemerkt. De paar modellen in de economische literatuur, die wèl rekening houden met onbetaalde arbeid, worden besproken. Plantenga en Sloep waren de eersten in Nederland die er op wezen dat in de modellering van het arbeidsaanbod rekening gehouden zou moeten worden met onbetaalde arbeid, omdat de organisatie van de betaalde en onbetaalde arbeid nauw met elkaar verbonden zijn. Tenslotte worden suggesties gedaan om in macro-economische modellen niet alleen in de modellering van het arbeidsaanbod, maar ook in de modellering van productie, consumptie, investeringen en besparingen rekening te houden met onbetaalde arbeid.

In hoofdstuk 8 wordt economische zelfstandigheid gedefiniëerd als financiële zelfstandigheid plus zorgzelfstandigheid. Financiële zelfstandigheid is een groter probleem dan zorgzelfstandigheid, omdat met een geldinkomen goederen en diensten gekocht kunnen worden die de zorgzelfstandigheid garanderen. Mede omdat over zorgzelfstandigheid onvoldoende gegevens bekend zijn, wordt in dit hoofdstuk vooral de financiële zelfstandigheid behandeld. Hoewel er verbetering te bespeuren valt, zijn er toch nog steeds veel meer vrouwen dan mannen die geen (arbeids)inkomen hebben. Als zij wel een (arbeids)inkomen hebben, ligt dit voor meer vrouwen beneden het sociale minimum dan voor mannen. De geringere mate van financiële zelfstandigheid blijkt ook uit het geringe aantal vrouwen dat de helft van het gezinsinkomen inbrengt en het geringe aandeel datvrouwen hebben in het totale arbeidsinkomen. 
Hoe kan de economische zelfstandigheid van vrouwen verbeterd worden is de vraag die in hoofdstuk 9 behandeld wordt. Huisvrouwenloon en een basisinkomen blijken niet tot gelijke economische posities van vrouwen en mannen te leiden. Niet de onbetaalde arbeid zèlf, maar de ongelijke verdeling daarvan over mannen en vrouwen zijn een valkuil voor de economische zelfstandigheid. Datzelfíde geldt voor de betaalde arbeid. Hoofdstuk 9 eindigt met de behandeling van een drietal pakketten maatregelen, die beogen zowel de onbetaalde als de betaalde arbeid gelijker over mannen en vrouwen te verdelen: gezinspolitiek, inkomenspolitiek en arbeidsmarktpolitiek. 

